UNIVERSIDADE DE SÃO PAULO

MUSEU DE ARQUEOLOGIA E ETNOLOGIA

PROGRAMA DE PÓS-GRADUAÇÃO EM ARQUEOLOGIA

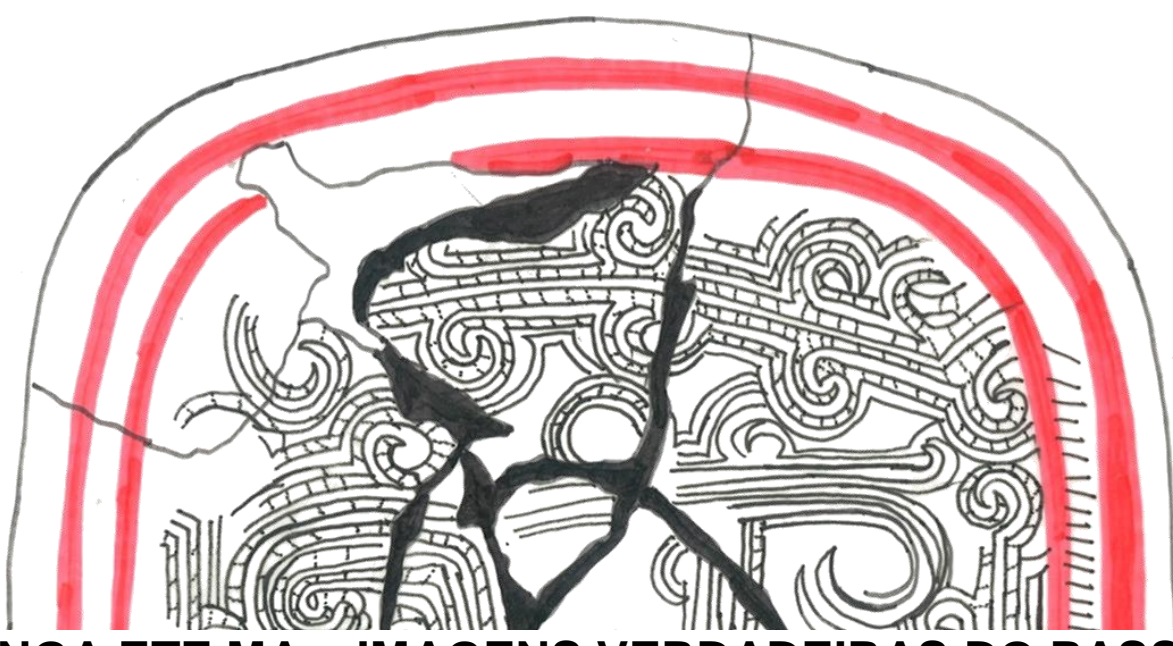

A'ANGA ETE MA - IMAGENS VERDADEIRAS DO PASSADO: UM ESTUDO SOBRE A CERÂMICA TUPI PINTADA DO INTERIOR

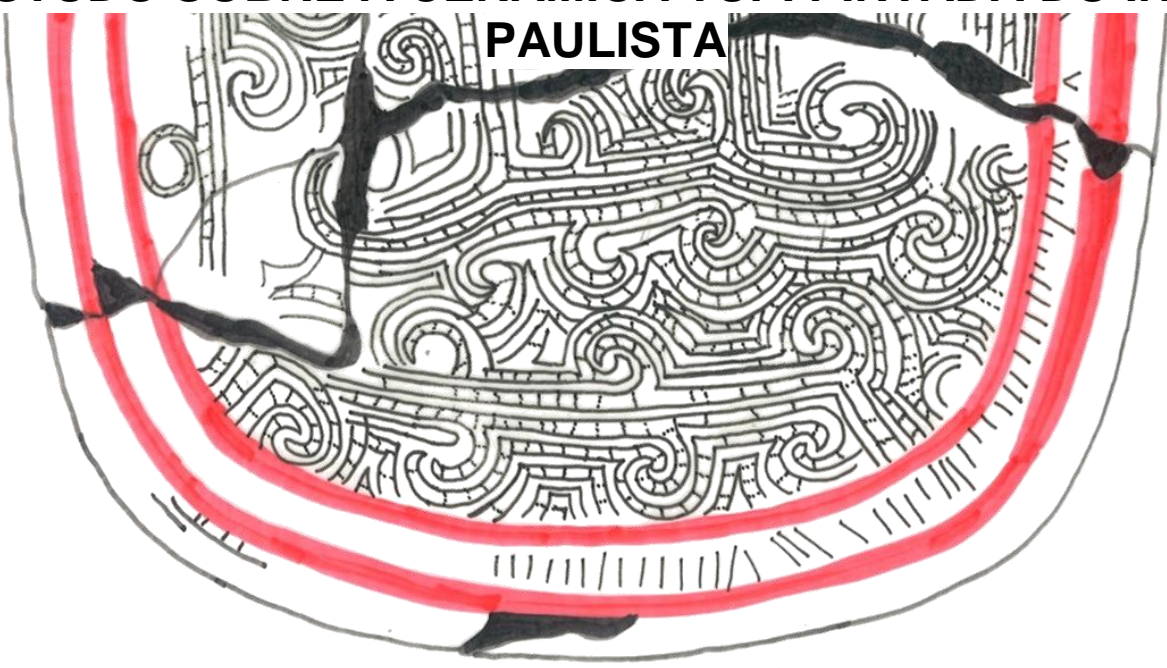

LETICIA RIBEIRO FERREIRA DA SILVA 
UNIVERSIDADE DE SÃO PAULO

MUSEU DE ARQUEOLOGIA E ETNOLOGIA

PROGRAMA DE PÓS-GRADUAÇÃO EM ARQUEOLOGIA

LETICIA RIBEIRO FERREIRA DA SILVA

\title{
A'ANGA ETE MA - IMAGENS VERDADEIRAS DO PASSADO: UM ESTUDO SOBRE A CERÂMICA TUPI PINTADA DO INTERIOR PAULISTA
}

\author{
Área de Concentração: Arqueologia \\ Linha de Pesquisa: Arqueologia e Ambiente

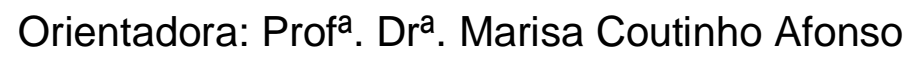

São Paulo

2017 
"Ao visitar as coleções arqueológicas e etnográficas dos índios no Brasil, invariavelmente os observadores se impressionam com os grandes vasos cerâmicos usados como urnas mortuárias. $E$ esses objetos de fato nos afetam. Tocam nossos sentidos e imaginação, de tal forma que, ante a presença física de um deles, é impossível a indiferença. Ao observá-los, o espectador sagaz é capaz de apreciar não só a beleza estética de vários dessas urnas, mas é capaz também de se deparar com vários seres. Por um lado, o(s) ser(es) cujos restos jazem na urna; por outro, os seres que povoam o universo simbólico desses povos e aos quais os rituais funerários deviam estar em relação."

(MANO, 2009 p. 112) 


\section{RESUMO}

Neste estudo, pretendo realizar um ensaio interpretativo sobre grafismos presentes na cerâmica arqueológica Tupi que compõem parte do acervo de museus e instituições de pesquisa do interior paulista. Para tanto, proponho um diálogo com outras áreas do conhecimento, como a antropologia da arte e a etnohistória.

A primeira contribui para o entendimento das relações estabelecidas entre sujeito (pessoa) e objeto, também entendido enquanto agente social, segundo a teoria de Gell.

A segunda propõe a leitura crítica de documentos etnohistóricos, entre eles registros de cronistas (a fim de compreender em que contextos sociais o uso de tais peças era recorrente) e também documentos etnográficos, sobretudo àqueles que apresentam narrativas mitológicas das populações de matriz cultural Tupi, pois como apresentou Tochetto (1996), acredito que estes motivos são representativos de fatos e personagens mitológicos.

Palavras chave: cerâmica Tupi, iconografia, estilos regionais 


\begin{abstract}
In this study, I intend to carry out an interpretative essay on Tupi archaeological pottery painting, in which integrates the collection of museums and research institutions in the country side of the state of São Paulo. Therefore, I propose a dialogue with other areas of knowledge, such as Anthropology of Art and Ethnohistory.

The first one contributes to understand the relations established between the person and the object, also understood as social agent, according to Gell's theory. The second one proposes a critical view of ethnohistorical documents, among them chroniclers' records (in order to understand in what social contexts the use of such pieces was recurrent) and ethnographic documents, especially those that present mythological narratives of the Tupi peoples. As Tochetto (1996) presented, I believe that these motifs are representative of mythological facts and characters.
\end{abstract} Key words: Tupi pottery, iconography, regional styles 


\section{AGRADECIMENTOS}

Primeiramente gostaria de fazer um agradecimento geral a todos e todas que estiveram presentes na minha vida de alguma forma nos últimos três anos. Foram anos intensos de muito aprendizado e amadurecimento que não alcançaria se não fosse a vivência com aqueles que estavam a minha volta.

Agradeço ao CNPq pelo apoio a esta pesquisa.

Agradeço à Profa. Marisa pela disposição em me orientar neste processo de descobertas, aos membros da banca de qualificação, Camila e Fabiola, pelos apontamentos pertinentes que contribuíram muito para o desenvolvimento desta pesquisa. Um agradecimento especial à Camila, que vem acompanhando minha atuação como arqueóloga desde o começo, colaborando sempre para reflexões que me permitem crescer enquanto profissional, pessoa e mulher.

Agradeço aos funcionários(as) e pesquisadores(as) de todos museus em que passei, por abrirem as portas e pela disponibilidade em me atender, muito obrigada: Daniella, João, Caio, Giovani (MHS); Profa. Ruth Künzli, Nikelli e Jean (CEMAARQ); Profa. Neide B. Faccio, Thiago e Paula (LAG e MAR); Claudia (FCJ); Erica, Cesar e Paulo (MSNA); Adhemar (MMEA); Rafael e Gabriela (MCS); Bernadete (MAI); João Carlos (CRAA). Agradeço também ao senhor Edson Franco de Godoy e sua esposa pela receptividade, ainda que eu não tenha conseguido acesso à coleção.

Aos amigos e colegas que fiz no decorrer destes anos no MAE/USP, principalmente Emerson, Marina, Leticia, Eliane, Jessica, Rafael, Laura, Glauco, Bruna, Mariana entre outros (me desculpem por não citar todos). Mas principalmente agradeço a Marina por me mostrar que é possível companheirismo em São Paulo.

Agradeço às funcionárias do MAE de maneira geral, mas principalmente ao pessoal da DAPE e documentação: Carla, Cristina, Francisca pela atenção com acesso à documentação; e aos funcionários da biblioteca: Alberto, Gilberto, Washington e principalmente ao Hélio, pelo bom humor e atenção de sempre.

Agradeço aos amigos e colegas que encontrei nos momentos difíceis de solidão no CRUSP, obrigada Patricia, Sandra, Lidiana, Simone, Marco, Pedro, André, Benigno, Bruna, Tatiane e Juliana, mas principalmente obrigada Michel por 
abrir as portas de sua casa e me receber tão bem e obrigada Daniel por me aguentar por tanto tempo.

Agradeço ao João pelos momentos de alívio em saber que é possível respirar fora da pesquisa, do trabalho e da universidade.

Agradeço aos amigos Bruno pela revisão deste texto e Alex por fazer os mapas que apresento aqui.

Agradeço ao Marcel pelas indicações de leitura e de coleções para seres incluídas nesta pesquisa.

Agradeço também aos amigos da Fundação Araporã, à Laura e Dulce pela preocupação e carinho de sempre, ao Renan, Daniel e Cleso pelos momentos de descontração e desabafos, a Natália e Debora pela parceria e disposição nos trabalhos em conjunto, à Josi pela empolgação com que vê os museus e que tanto me inspira, à Graziela pela empolgação contagiante e sempre performática, à Adriana pelos momentos de descontração. Agradeço também à Virgínia pela dedicação e preocupação. E um agradecimento especial ao Robson por abrir as portas de uma arqueologia engajada e pela dedicação com que vem acompanhando minha trajetória na arqueologia.

Agradeço também às amigas que se mantiveram presentes mesmo distantes, obrigada Flávia, Larissa, Raíssa, Helga e Marina.

Por fim, o maior agradecimento e o mais sincero sentimento de gratidão à minha mãe Celina, meu pai Manoel e minha avó Maria (também conhecida como Dona Fiota rs) pelo apoio desde meus primeiros passos na arqueologia, mesmo sendo uma carreira nada convencional. Agradeço também à minha irmã lara, meus tios e tias, primos e primas que sempre me apoiaram e acompanharam, muitas vezes com curiosidade e orgulho minha vida movimentada e incerta. 


\section{LISTA DE SIGLAS}

CEMAARQ: Centro de Museologia, Antropologia e Arqueologia

CRAA: Centro Regional de Arqueologia Ambiental (MAE/USP)

FCJ: Fundação Cultural Jacareí

MAI: Museu de Arqueologia de lepê

MAR: Museu de Arqueologia Regional "José Luiz de Morais"

MCS: Museu da Cidade de Salto

MHS: Museu Histórico Sorocabano

MMEA: Museu Municipal "Elizabeth Aytai"

MMMG: Museu Municipal de Mogi-Guaçu

MNSA: Museu do Santuário Nacional de Aparecida

PP: Pontal do Paranapanema

PRONAPA: Programa Nacional de Pesquisas Arqueológicas

Proj Par: Projeto Paranapanema

\section{LISTA DE FIGURAS}

Figura 1: Escavação da professora Conceição Borges Ribeiro em Aparecida na década de 1950

Figura 2: Vasilha cerâmica encontrada por Conceição Borges Ribeiro em

Aparecida. Atualmente a única peça do acervo arqueológico em exposição.........22

Figura 3: Mapa manuscrito de Manuel Pereira de Godoy apontando para sítios

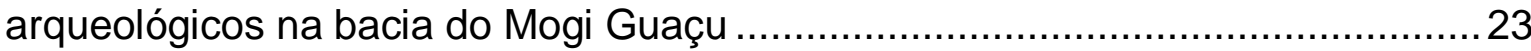

Figura 4: Plano Cartográfico do Projeto Paranapanema, Morais, 1995 ................26

Figura 5: Mapa arqueológico da região de Sorocaba - Wanderson Esquerdo

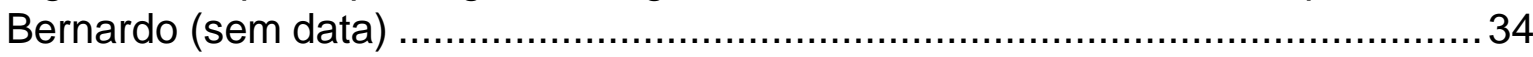

Figura 6: Mapa da Província de São Paulo promovido pela Sociedade Promotora de Imigração de São Paulo em 1886 destaca o "sertão despovoado" na região oeste do estado.

Figura 7: Últimos indígenas (sem denominação étnica) que habitaram a "Aldeia

Velha de Carapicuiba". Fotografia de 1950 (Acervo MHS)

Figura 8: Relação quantitativa de indivíduos analisados em cada nível de análise

Figura 9: Decalque de vasilha com pintura interna

Figura 10: Fluxograma da cadeia operatória da cerâmica Tupi baseada em La

Salvia e Brochado (1989)

Figura 11: Etapas do processo de montagem a partir da técnica do acordelado (SCATAMACHIA, 2004: 292)

Figura 12: Grau de plasticidade da pasta

Figura 13: Vasilhas com acabamento cromático (pintura) na parte superior ao bojo

e acabamento plástico (corrugado) na parte inferior ao bojo 71

Figura 14: Vasilha com engobo vermelho na face externa e pintura na face interna

(MHS-03). .72

Figura 15: Vasilha com marcas de dedos na face interna próximo ao lábio ..........72

Figura 16: Vasilha (FCJ 03) com mancha escura na superfície externa e núcleo escuro no plano de fratura resultantes de queima em atmosferas oxidantes ........76

Figura 17: Classificação dos planos de fratura (MORAES, 2006: 11) ....................77 
Figura 18: Morfologias de base

Figura 19: Morfologias de bordas segundo Robrahn-González (2000).................81

Figura 20: Vasilha cerâmica com borda expandida. MNSA 02 …........................ 82

Figura 21: Morfologias contorno de boca: 1. Circular (FCJ 07); 2. Elíptica (MNSA

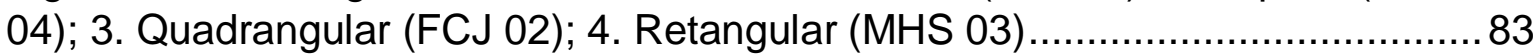

Figura 22: Contorno das vasilhas (CEMAARQ 04; FCJ 05) ................................ 85

Figura 23: Vasilha com campos gráficos na face interna (FCJ 04) .......................92

Figura 24: Vasilha com pintura na face externa (CEMAARQ 10$)$ ).......................93

Figura 25: Vasilha com motivos feitos com cor escura - vermelho (CEMAARQ 10)

Figura 26: Vasilha com motivos feitos com cor muito escura -preto (CEMAARQ

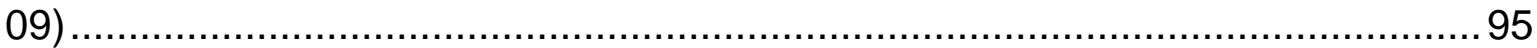

Figura 27: Vasilha com motivos feitos com cor escura e muito escura (CEMAARQ

04) .95

Figura 28: Vasilha aberta com motivo no campo primário confeccionados em linhas contínuas escuras sobrepostas por linhas pontilhadas muito escuras (MHS 03).

Figura 29: Vasilha com motivos pintados sobre engobo vermelho (CEMAARQ 05)

Figura 30: Vasilha com motivos simples (MAR 04) 103

Figura 31: Vasilhas de dimensões diferentes apresentam o mesmo padrão (FCJ 04, FCJ 02) 109

Figura 32: Imagem produzida por Theodore de Bry no século XVI, inspirado na obra e nas gravuras produzidas por Hans Staden. $\mathrm{Na}$ imagem vasilhas abertas recebem a cabeça e as partes internas do sacrificado. Ao mesmo tempo, vasilhas menores (provavelmente do tipo cambuchí caguâba) são utilizadas para o

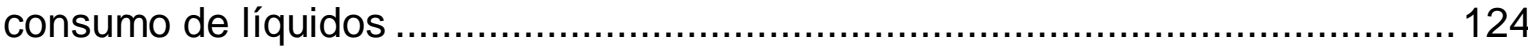

Figura 33: Possíveis representações corporais segundo Prous (2009) ............. 125

Figura 34: Vasilhas com representação humana ………................................... 126

Figura 35: Vasilha com representações humanas, cujos membros se apresentam de

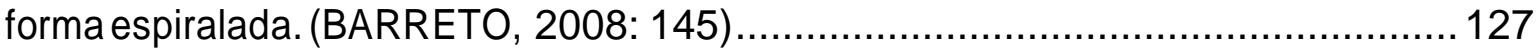
Figura 36: Mulheres preparam o prisioneiro para a morte ritual. Ilustração de Theodore de

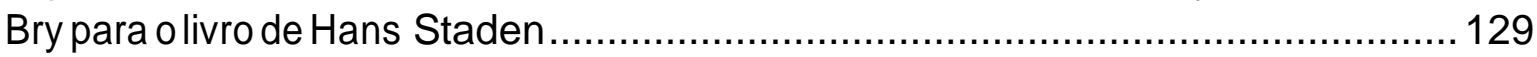

Figura 37: Vasilha MSNAQ 04 com padrão "ampulheta" ................................. 130 Figura 38: À esquerda o padrão tayngava presente na pintura corporal de um Assurini (MÜLLER, 1992); à direita o motivo mínimo do padrão tayngava

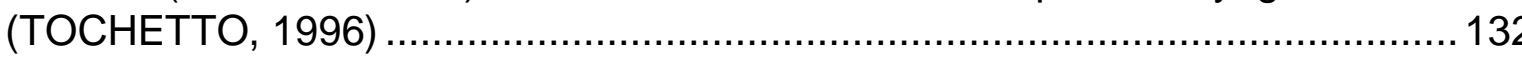
Figura 39: Motivos representativos de seres mitológicos: 1. Taangap faña (gente, dedos esticados/garra); 2. Sapo kururu; 3 taangap ta (criança com o pai) (RIBEIRO, 1987b:

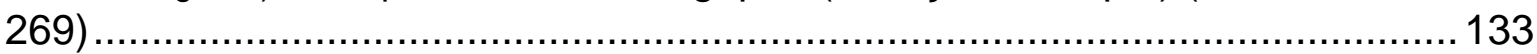
Figura 40: Vasilha (CEMAARQ 10) com motivos "sapo" e "cruz" ...................... 134 Figura 41: Vasilha do tipo cambuchí (MAl 01) com destaque para motivo com padrão "cruz" (Imagem de FACCIO, 2011: 160) .......................................................... 136

Figura 42: Desenho "casco de jaboti" presente na vasilha CEMAARQ 03 (à esquerda) e reproduzido em papel por Nazaré, Waiãpi (GALLOIS, 1992: 214). 137 


\section{LISTA DE TABELAS}

Tabela 1: Relação de indivíduos analisados por instituição

Tabela 2: Distribuição dos padrões gráficos na região do Pontal do Paranapanema

Tabela 3: Distribuição dos padrões gráficos Vale do Paraíba..............................120

Tabela 4: Distribuição dos padrões gráficos Tietê/Sorocaba ............................. 120

\section{LISTA DE GRÁFICOS}

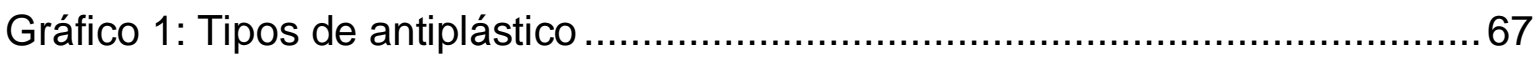

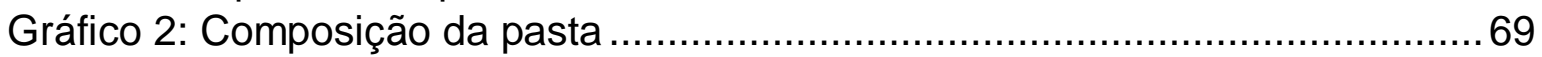

Gráfico 3: Ferramenta utilizada na aplicação dos grafismos .................................73

Gráfico 4: Classificação da queima a partir dos planos de fratura ........................ 78

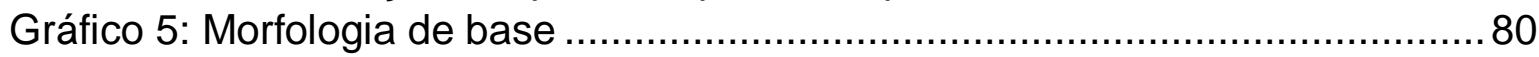

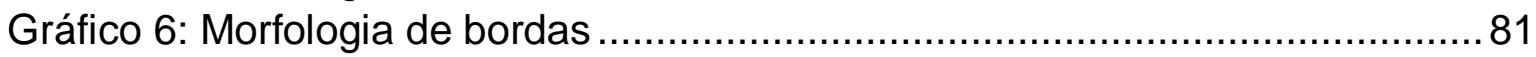

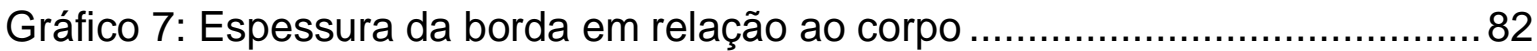

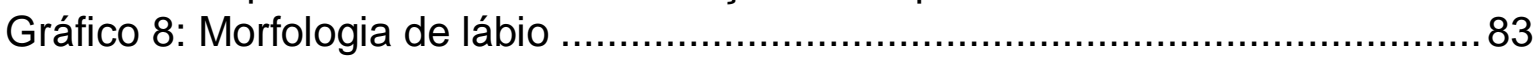

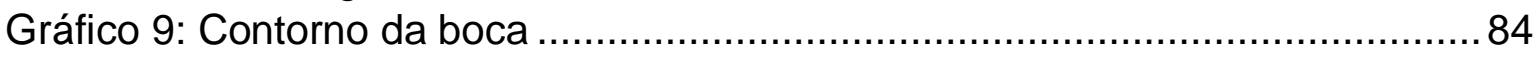

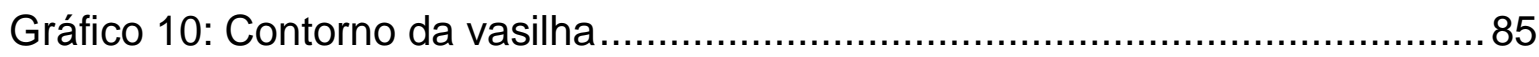

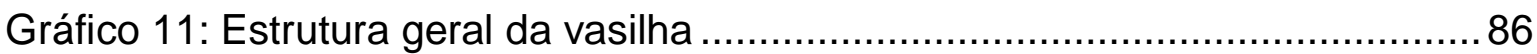

Gráfico 12: Variação de diâmetros da boca, alturas e larguras por tipos de vasilha

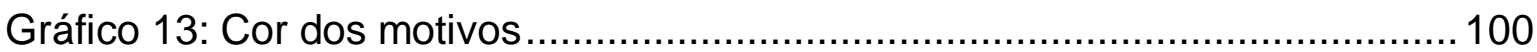

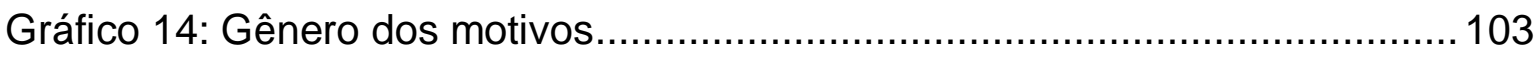

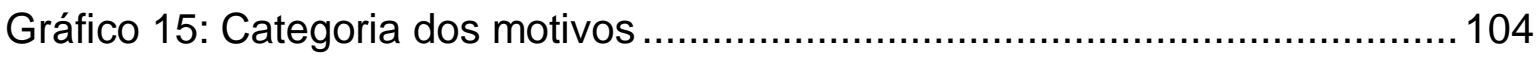

\section{LISTA DE PRANCHAS}

PRANCHA 01: Localização das instituições de guarda dos acervos analisados

PRANCHA 02: Morfologias - Cambuchí

PRANCHA 03: Morfologias - Cambuchí caguâba

PRANCHA 04: Morfologias - Ñaembé / Teembirú

PRANCHA 05: Motivos externos

PRANCHA 06: Motivos internos

PRANCHA 07: Distribuição espacial dos motivos gráficos 


\section{Sumário}

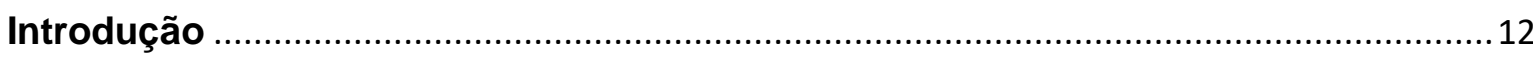

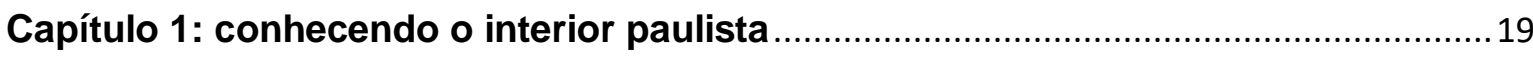

1.1. Escavando as coleções: um esboço da arqueologia Tupi do interior paulista... 19

1.2 Ocupação Tupi no estado de São Paulo: um olhar etnohistórico ......................... 36

Capítulo 2: Base teórica para uma arqueologia crítica................................................ 45

2.1 Conceitos tradicionais, novas abordagens ................................................. 48

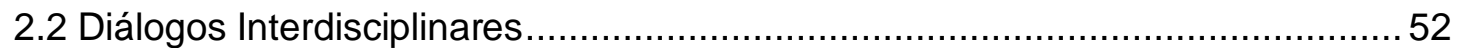

Capítulo 3: Pressupostos Metodológicos e Abordagens Analíticas ……....................57

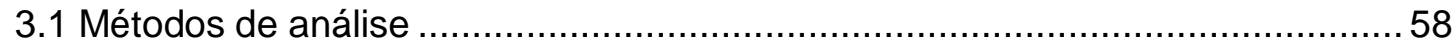

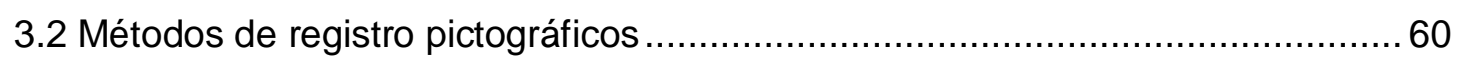

Capítulo 4: A análise das Coleções e os Resultados Obtidos .......................................63

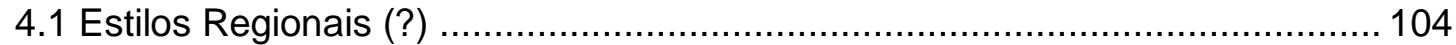

4.2 Produção cerâmica: arte, comunicação e representação ................................ 120

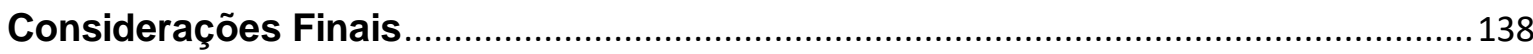

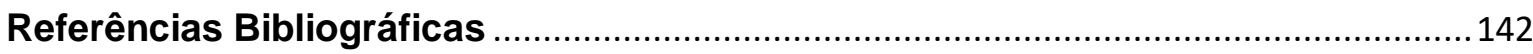

\section{Anexos}

Ficha de Análise

Chave para análise 


\section{Introdução}

“A'ANGA ETE MA"! A expressão que dá nome à esta dissertação nos diz em tupi-guarani: IMAGENS VERDADEIRAS DO PASSADO!

A escolha do título, que aparece na capa com um grafismo ao fundo, representa uma tentativa de aproximação com o universo cósmico das populações falantes desta língua a partir de dois elementos: a imagem, através dos grafismos estampados nas vasilhas cerâmicas (assim como em outros corpos - humanos e não-humanos), e a palavra, através dos termos em tupi-guarani que denominam, além do título na dissertação, as vasilhas estudadas.

Antes de dar início à exposição da pesquisa, creio que seja relevante apresentar os caminhos e descaminhos percorridos desde meados 2014, quando ingressei no programa de mestrado em arqueologia no MAE/USP sob orientação da Profa. Maria C. Afonso. Na ocasião a proposta de pesquisa consistia em realizar um levantamento em museus e/ou instituições de pesquisa da região nordeste do estado de São Paulo com o objetivo de identificar e registrar vasilhas arqueológicas inteiras e com pintura a fim de criar um banco de dados para futuras análises iconográficas. Tendo me deparado com escassez de vasilhas pintadas inteiras ou em bom estado de preservação, optei no decorrer da pesquisa por aumentar o recorte geográfico, incorporando as regiões Pontal do Paranapanema, Tietê/Sorocaba e Vale do Jacareí. Os objetivos também se expandiram e culminaram na análise da produção de vasilhas pintadas sob três enfoques, a saber: tecnológico, estilístico e iconográfico.

Neste contexto busco trazer para o debate arqueológico aspectos fundamentais da cultura das populações produtoras, seja no campo das práticas cotidianas (de preparo, consumo e armazenamento de alimentos e líquidos) como nas práticas ritualísticas em que se inserem as vasilhas ora estudadas.

Devo esclarecer que estas são reconhecidas no cenário arqueológico Tradição ${ }^{1}$ Tupiguarani, reconhecida e definida pelo Programa Nacional de Pesquisas Arqueológicas (PRONAPA) a partir de pesquisas desenvolvidas entre

\footnotetext{
${ }^{1} \mathrm{O}$ conceito de tradição arqueológica foi cunhado pelos pesquisadores do PRONAPA com o objetivo de classificar e ordenar o registro arqueológico, sendo definido pelos mesmos como um conjunto de elementos ou técnicas que se distribuem espacialmente apresentando persistência temporal (PRONAPA, 1976).
} 
as décadas de 1960 e 1970, com base em um conjunto de elementos perceptíveis no registro arqueológico que permitissem estabelecer padrões classificatórios (CORREA, 2014), como os aspectos "decorativos" e formais.

"As técnicas diagnósticas de decoração da cerâmica compreendem a
pintura sôbre engobo branco, o corrugado, o escovado e o ungulado.
(...). Há uma grande variedade de formas de vasos, comportando desde
tigelas arredondadas até grandes urnas funerárias de ombros angulares.
As tigelas são por vezes quadradas ou elípticas que propriamente
circulares" (PRONAPA, 1969: 20).

Inicialmente, o termo Tupiguarani, escrito em uma só palavra, foi adotado pelos pronapianos para designar apenas este conjunto de vestígios e artefatos arqueológicos, sem apresentar qualquer tentativa de aproximação etnográfica.

\footnotetext{
"Nesta abordagem do Pronapa eliminou-se o uso das informações históricas e linguísticas, passando-se a empregar exclusivamente as arqueológicas. Iniciou-se, entre os arqueólogos, um período de esquecimento das diferenças de identidades e de cultura material reconhecidas entre os Tupi, enquadrando-se numa única categoria povos historicamente conhecidos tanto por suas igualdades como por suas diferenças e oposições" (NOELLI, 1996: 16).
}

Ainda que houvesse uma tentativa por parte dos pesquisadores do PRONAPA em não estabelecer relações de continuidade entre vestígios arqueológicos e populações indígenas do presente, tal aproximação é inevitável.

Já ao final do século XIX Ladislau de Souza Mello Netto (1885), então diretor do Museu Nacional, busca relacionar o material cerâmico da coleção arqueológica do Museu Nacional com populações indígenas atuais a partir de narrativas míticas e crônicas de viagem daqueles que mantiveram contato com grupos Tupi da costa entre os séculos XVI e XVII, entre eles o alemão Hans Staden e o francês Jean de Léry.

Este exercício foi retomado no século XX por Angyone Costa (1934) que a adiciona ao debate dados linguísticos levantados a partir de registros gramaticais realizados por jesuítas entre os séculos XVI e XVIII, além de estudos realizados por pesquisadores alemães (ao que o autor denomina "escola alemã" para classificação moderna dos povos indígenas brasileiros) durante o século XIX.

Por algumas décadas a aproximação entre registro arqueológico e populações indígenas se manteve silenciada, sobretudo no período de repressão militar vivido no cenário brasileiro entre os anos de 1964 e 1985, uma vez que não era de interesse do Estado o aprofundamento na construção de narrativas 
históricas nacionais que integrassem as populações indígenas como atores sociais (FUNARI, 1995; SCHIAVETTO, 2003).

A partir dos anos 1980, busca por uma prática arqueológica que dialogue mais com temas sociais e antropológico ganha forças novamente, sobretudo na figura de Brochado (1984) que, com base em dados arqueológicos, etnohistóricos e linguísticos, apresenta um modelo que aponta para dois grandes conjuntos artefatuais no que se refere às cerâmicas da tradição Tupiguarani, a saber: Cerâmica Guarani, associada aos grupos meridionais, com predominância de vasilhas com tratamentos plásticos; e Cerâmica Tupinambá, associada aos grupos do litoral, com predominância de vasilhas pintadas. O modelo de Brochado para o estudo destes conjuntos cerâmicos está baseado na tese sobre um centro de origem e dispersão de populações Tupi pelo território sul-americano. Inspirado nas ideias de seu orientador Donald Lathrap (1970), Brochado aponta para o território amazônico como um importante centro de difusão das populações Tupi do passado. Para estes autores, estas populações teriam assumido dois movimentos migratórios principais, um no sentido meridional e o outro no sentido litoral, dando origem aos conjuntos cerâmicos supracitados.

Não pretendo me aprofundar aqui nas discussões e teorias sobre origem e dispersão de populações Tupi, já trabalhada por outros pesquisadores ${ }^{2}$ (BROCHADO, 1984; NOELLI 1993, 1996; CORREA, 2014), tampouco nos debates pronapianos que compreendem as tradições, subtradições ${ }^{3}$ ou fases arqueológicas, conceitos que vem sendo criticados pela sua limitação teórica e metodológica.

Diante do exposto, preciso esclarecer e justificar algumas escolhas. Primeiramente, justifico minha escolha por uma narrativa feita em primeira pessoa do singular, algo muito incomum em textos acadêmicos. Sustento esta escolha pela necessidade de autoria dos trabalhos acadêmicos, pois somos, como bem lembra Michael Shanks (2005), produtos e produtores de uma sociedade. Nas palavras do autor:

\footnotetext{
${ }^{2}$ Citei aqui apenas alguns pesquisadores que acredito terem trabalhado bem esta questão, mas devo lembrar que a bibliografia acerca de estudos de populações Tupi, seja sob uma perspectiva arqueológica, antropológica ou linguística é ampla e, no caso da arqueologia, é recorrente que as pesquisas dediquem ao menos um capítulo para esta temática.

${ }^{3} \mathrm{O}$ termo "subtradição" ainda causa confusões, uma vez que este raramente é definido. Porém, o mesmo costuma indicar um conjunto de sítios ou registros arqueológicos em uma região restrita.
} 


\begin{abstract}
"Archaeologists too are motivated, interested, located, strategizing. (...). The concept of discourse refers to this notion of archaeology as a mode of cultural production. It has enormous implications, most notably that archaeologists don't so much discover the past as produce accounts of it; their attention is drawn as much to contemporary values and attitudes as to the past itself" (SHANKS, 2005: 137).
\end{abstract}

Construo, portanto, um discurso/narrativa permeado por uma carga social, histórica, política e econômica que fazem parte da minha trajetória pessoal e acadêmica que influenciam minhas escolhas enquanto arqueóloga.

Justifico também minha escolha pelo objeto de estudo, a cerâmica pintada, pois acredito que a partir pintura é possível elencar as particularidades e os modos de expressão de etnicidade e individualidade. É na pintura que a criatividade humana encontra liberdade de expressão, ainda que a ceramista seja parte integrante de um sistema social cujos modos de fazer cerâmica, passados de geração pra geração, se perpetuam por longos períodos de tempo e numa vasta porção territorial.

Além disso, sabe-se que as cerâmicas Tupiguarani são caracterizadas pela presença de decoração plástica ou pintada, tratando-se da única tradição brasileira a usar policromia fora da Bacia Amazônica (PROUS, 2009: 11, grifo meu), porém, ainda que apresente grande dispersão territorial, poucos (as) pesquisadores (as) se debruçam sobre os motivos decorativos ${ }^{4}$ das cerâmicas arqueológicas e seu papel ativo na sociedade.

No estado de São Paulo, poucos pesquisadores se dedicaram ao estudo da arte gráfica nas cerâmicas Tupi, limitando-se a descrição e registro dos motivos sem realizar qualquer tentativa de aproximação com o universo cosmológico das populações indígenas deste tronco linguístico. Estes estudos se tornaram referência para outros(as) pesquisadores(as) que buscam conhecer a produção oleira das populações Tupi do passado e que veem na produção gráfica uma possibilidade para a identificação de grupos locais/regionais que pertencem a mesma matriz cultural.

Neste contexto destaco a atuação de dois pesquisadores: o arqueólogo Desidério Aytai (1991), que com sua esposa Elizabeth Aytai, realizou escavações que resultaram em um significativo acervo arqueológico composto de material

\footnotetext{
${ }^{4}$ Não creio que a pintura em cerâmica cumpra apenas função estética e decorativa, no entanto, adoto nesata dissertação o termo decoração para designar as pinturas presentes nas vasilhas em estudo por não encontrar outro mais adequado à situação.
} 
cerâmico, lítico (polido e lascado) e ósseo, atualmente sob responsabilidade do Museu Municipal "Elizabeth Aytai" no município de Monte Mor (SP). Na ocasião de sua pesquisa, Aytai realiza importantes registros de fragmentos pintados coletados durante a escavação do sítio Rage Maluf no município de Monte Mor, divulgando a variabilidades dos motivos gráficos identificados na região; e o biólogo Manuel Pereira de Godoy, que desenvolveu pesquisas na região de Pirassununga entre 1944 e 1963 (MORAES, 2007), reunindo um acervo composto por material cerâmico e lítico (polido e lascado), dos quais podemos destacar a presença de cerâmicas pintadas, associadas a ocupações Tupi na região. Em seu livro, Godoy (1974) registra os motivos presentes em vasilhas e fragmentos cerâmicos de sua coleção particular. Esta mesma coleção veio a ser alvo de estudos por Camila Azevedo de Moraes (2007), que trouxe novas interpretações sobre tais coleções a partir de uma análise da variabilidade artefatual, apontando também para possibilidades interpretativas sobre a função cosmológica de alguns padrões gráficos.

Em um contexto mais amplo, também são importantes as contribuições de Marois et al.(1994) que realizam importante ensaio sobre a composição das decorações das cerâmicas Tupi. Neste ensaio os autores propõem um método de análise a partir da decomposição dos motivos, a fim de identificar os elementos que compõem o todo do desenho.

No que compete ao estudo interpretativo da iconografia da cerâmica Tupi pintada, destaco o trabalho desenvolvido por Fernanda Tochetto (1996) em seu artigo "Possibilidades de Interpretação do Conteúdo Simbólico da Arte Gráfica Guarani", onde a autora analisa os padrões gráficos da cerâmica Guarani, bem como a pintura corporal de populações Tupi atuais, como expressão de um pensamento simbólico. Assim a cerâmica pintada seria parte de um sistema de comunicação no qual os grafismos fazem referências às narrativas míticas do grupo.

O artigo de Tochetto influenciou o trabalho de Prous, que em seu livro "Arte Pré-histórica do Brasil" (2011), dedica um capítulo à apresentação e interpretação dos motivos identificados em vasilhas provenientes de diversas partes do Brasil.

Assim, meu objetivo neste estudo se concentra em dois pontos: identificar semelhanças e diferenças nos padrões gráficos evidenciados nas vasilhas 
analisadas a fim de inferir a possibilidade de estilos regionais que possam indicar a presença de grupos indígenas distintos (embora filiados à mesma matriz cultural) em diferentes regiões do estado de São Paulo; elencar possibilidades para o papel social desempenhado por essas cerâmicas.

Tendo delimitados os objetivos deste trabalho e justificado minhas escolhas, passo agora a uma breve apresentação da trajetória desta pesquisa, que apresentava em 2014 uma proposta bem diferente da atual. Meu primeiro objetivo consistia em realizar um levantamento em museus e/ou instituições de pesquisa da região nordeste do estado de São Paulo, mais especificamente àquela entre as bacias dos rios Pardo e Mogi-Guaçu, tendo como foco principal identificar e registrar coleções arqueológicas Tupi que apresentassem pintura, a fim de estabelecer um panorama geral da atual situação destas coleções para futuras análises iconográficas.

Apesar da densidade de sítios arqueológicos na região ${ }^{5}$, as condições físicas destas coleções, tanto no que diz respeito à preservação dos motivos, quanto no que diz respeito a sua integridade física, dificultaram o desenvolvimento da proposta inicial.

Assim, a opção que encontrei foi ampliar a área de abrangência do projeto, me dedicando a todo o interior paulista, buscando peças que apresentassem ao menos $50 \%$ de integridade ou que fosse possível identificar seu contorno, assim seria possível realizar um ensaio interpretativo dos padrões gráficos em conjunto com a morfologia das vasilhas a partir da aproximação com dados etnográficos e etnohistórico.

Por fim, apresento nesta introdução a estrutura geral desta dissertação, organizada da seguinte maneira:

No Capítulo 1, intitulado "Conhecendo o interior paulista", trago informações contextuais acerca da presença Tupi no estado de São Paulo. O capítulo está organizado em dois tópicos: "Escavando as coleções: um esboço da arqueologia Tupi do interior paulista", no qual dedico algumas páginas aos dados arqueológicos que temos sobre o estado tendo como foco o estudo de coleções, sobretudo àquelas que foram alvo de estudo nesta dissertação; "Ocupação Tupi

\footnotetext{
${ }^{5}$ Em seu mestrado, Moraes aponta para a riqueza do contexto arqueológico nesta região, sobretudo no que diz respeito a presença de sítios arqueológicos classificados como pertencentes à "Tradição Tupiguarani”.
} 
no estado de São Paulo: um olhar etnohistórico", no qual trago informações acerca da presença de populações Tupi no estado de São Paulo, sua relação com outros grupos indígenas do entorno com a população colonial.

No Capítulo 2, intitulado "Bases teóricas para uma arqueologia crítica", apresentarei os principais referenciais teóricos que nortearam a interpretação dos dados de análise. Para tanto, optei por dividir o capítulo em dois tópicos: "Conceitos tradicionais, novas abordagens", dedicado aos principais conceitos norteadores desta pesquisa; "Diálogos interdisciplinares", traz referências de outras áreas do conhecimento, sobretudo a Antropologia da Arte e a Semiótica. Neste tópico pretendo apresentar 0 artefato arqueológico como objeto vivo responsável por desencadear ações e criar memórias ao longo do tempo.

O Capítulo 3, denominado "Pressupostos Metodológicos e Abordagens Analíticas", está organizado em dois tópicos: "Métodos de análise", dedicado à apresentação dos principais referenciais metodológicos e conceitos básicos que nortearam as diversas perspectivas analíticas (tecno-tipológica, estilística e iconográfica); "Métodos de registro pictográfico", no qual dediquei algumas páginas à descrição dos métodos adotados para o registro do material estudado.

No capítulo 4, intitulado "A análise das Coleções e os Resultados Obtidos", apresento e discuto os dados que alcancei com a análise.

Por fim, apresentarei minhas "Considerações Finais" sobre a pesquisa retomando de maneira reflexiva os dados alcançados em análise. 


\section{Capítulo 1: conhecendo o interior paulista}

Neste capítulo apresento um pouco do contexto arqueológico e etnohistórico do interior do estado de São Paulo, tendo como foco, no caso da arqueologia, as informações geradas a partir de estudos de coleções arqueológicas e, no caso da etnohistória, mergulhar nas narrativas de viajantes, bandeirantes, pesquisadores, entre outros, que circularam pelas terras paulistas em diferentes momentos da história e relataram suas experiências de contato com grupos indígenas que habitavam a região, realizando uma leitura crítica destes relatos que muito colaboram para o conhecimento das populações indígenas historicamente conhecidas e como eram vistos pela população não indígena.

As informações deste capítulo servirão de subsídio para que o ensaio interpretativo realizado no Capítulo 4, onde busco cruzar informações de diferentes fontes, entre elas os dados de análise alcançados durante minha pesquisa de campo e àqueles produzidos por outros pesquisadores que se dedicaram ao estudo de coleções paulistas e, por fim, os dados etnohistóricos que nos aproxima, mesmo que de maneira limitada, das populações indígenas do passado.

\subsection{Escavando as coleções: um esboço da arqueologia Tupi do interior paulista}

Muitas instituições em todo o estado possuem em suas reservas-técnicas ou exposições uma ou mais vasilhas cerâmicas associadas ao elemento Tupi, cujos desenhos chamaram atenção e, consequentemente, ganharam destaque por seu aspecto estético. É comum que neste contexto algumas vasilhas tenham sido coletadas de forma assistemática, por pesquisadores do passado ou pela população local. Logo, pouco se sabe sobre seu contexto arqueológico. Este é o caso de algumas coleções/vasilhas que analisei no decorrer de meu mestrado. Diante disto, busco neste tópico apresentar um quadro geral da arqueologia Tupi do estado de São Paulo, com foco em coleções, a fim de estabelecer um contexto arqueológico mais amplo para estas vasilhas/coleções. 
Segundo alguns pesquisadores que se dedicaram ao estudo da história da arqueologia no Brasil (BARRETO, 1999/2000; PROUS, 1992), esta começa a se desenvolver cientificamente a partir da atuação de pesquisadores estrangeiros em território nacional na segunda metade do século XX. No entanto, é importante salientar que a formação de coleções e o estudo de objetos e contextos arqueológicos vinha se desenvolvendo desde o século XIX.

Conceição Borges Ribeiro Camargo atuou no Vale do Paraíba Paulista nos anos 1950 em escavações e estudos de objetos arqueológicos que vinham sendo evidenciados desde as primeiras décadas do século XX. A autora afirma que

\begin{abstract}
"A riqueza da região de Aparecida em objetos arqueológicos já tem sido assinalada e eu mesma a ela me tenho referido em trabalhos e artigos. Merece um estudo não só no plano científico ao qual tantos esclarecimentos pode trazer sobre as representações, figurações e outros aspectos da cultura indígena, bem assim no plano artístico, onde há achados do melhor sentido, quer no âmbito plástico, quer no decorativo, ou no histórico" (CAMARGO, 1990 - X Simpósio de História do Vale do Paraíba).
\end{abstract}

Segundo a autora, a primeira evidência arqueológica do Vale do Paraíba ocorreu em 1908 durante obras na antiga Estação de Ferro Central do Brasil, no município de Aparecida, em que se encontrou uma igaçaba ${ }^{6}$ ainda com ossos dentro. Duas décadas depois, em 1928, durante as obras de reconstrução de uma casa no mesmo município, outra igaçaba foi encontrada, contendo um crânio, dentes e uma tampa. Em 1939, nas terras do antigo prefeito de Aparecida, Américo Alves Pereira Filho, mais duas peças indígenas (cerâmicas), foram identificadas.

Tantos achados despertaram o interesse da professora que, em 1935, durante a derrubada de uma árvore no local onde atualmente se encontra a Estação Rodoviária, acompanhou a retirada de uma grande igaçaba do local. Assim, Conceição Borges pede permissão à prefeitura para realizar escavações no local. Junto com o colega Vicente Camargo, a professora dá início às suas pesquisas.

"Levamos enxada, pá, picareta e uma vassoura, pazinha de pedreiro, padiolas improvisadas e mais material emprestados dos vizinhos. Era um sítio arqueológico e continuando a pesquisa de campo, dentro de Aparecida e arredores, deparamos com mais dois sítios, baseando na

\footnotetext{
${ }^{6} \mathrm{O}$ termo igaçaba designa vasilhas de cerâmica de grande porte destinadas ao armazenamento de água. Este vocábulo, de origem tupi-guarani, foi registrado por Anchieta (apud Panachuk 2004). Dados etnohistóricos apontam para a utilização destas vasilhas no consumo de cauim, bebida fermentada a base de mandioca, podendo ser reaproveitadas em sepultamentos.
} 
diversidade e ornamentos delineei três zonas de cerâmicas distribuídas por suas respectivas zonas geográficas" (CAMARGO, 1990: 13).

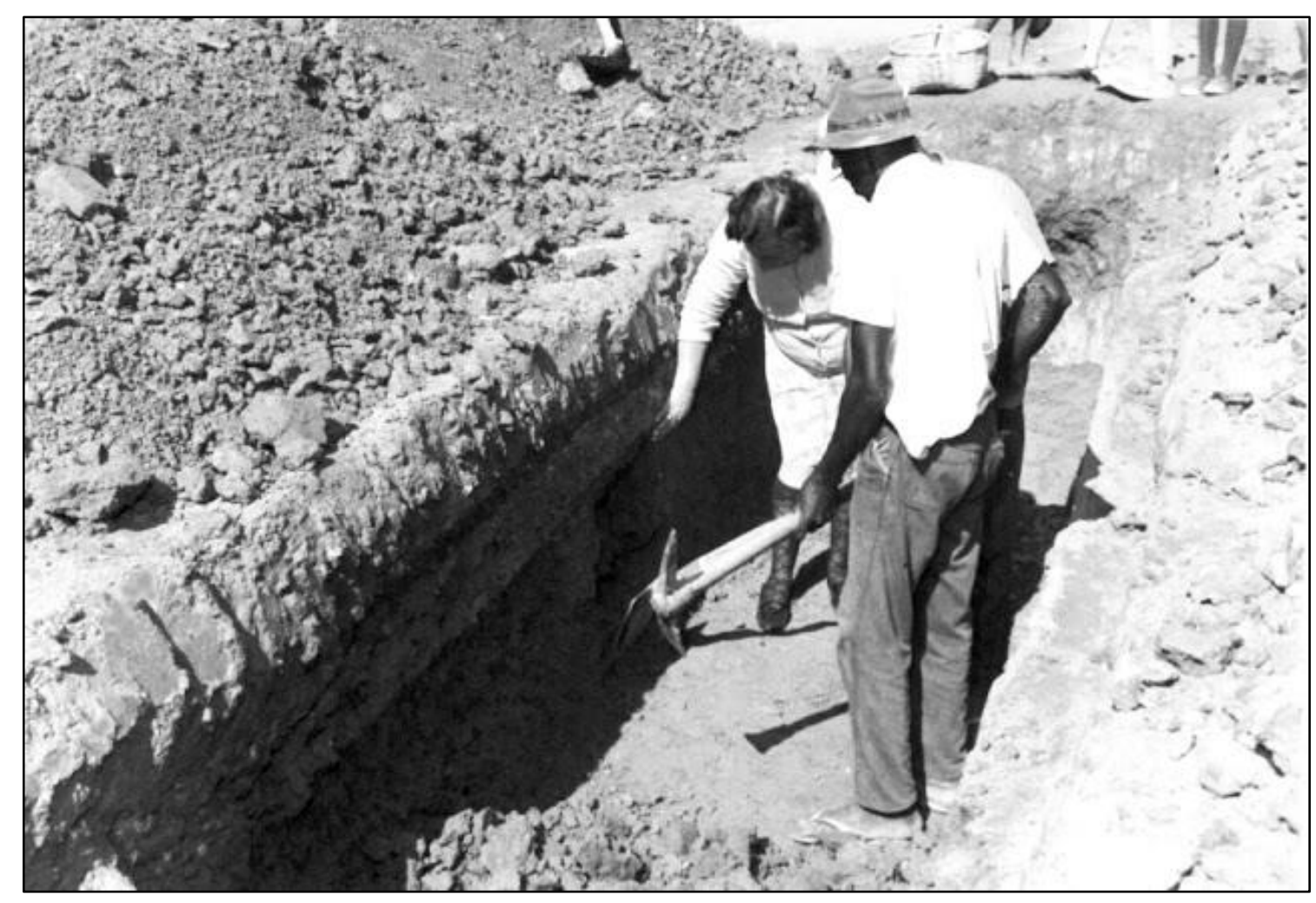

Figura 1: Escavação da professora Conceição Borges Ribeiro em Aparecida na década de $1950^{7}$

A partir daí Conceição realizou algumas escavações independentes, mas somente a partir de 1957 (ver Figura 1) começou a realizar pesquisas de forma sistemática, quando contou com o apoio da professora Herta Schueur da Universidade de São Paulo em trabalhos no município de Aparecida.

Atualmente, parte da coleção formada por Conceição Borges encontra-se dispersa em algumas instituições do estado de São Paulo, entre elas o Museu Santuário Nacional de Aparecida, aberto em 1956 a partir do acervo arqueológico doado pela professora, integrando aqui minha pesquisa de mestrado. Vale ressaltar que o acervo arqueológico resultante da atuação de Conceição encontrase, em sua maioria, guardado na reserva técnica do MNSA, apenas uma peça (Figura 2) integra a exposição permanente do museu.

Algumas peças ainda, foram doadas a outras instituições: Museu Paulista ${ }^{8}$, Museu Histórico e Pedagógico de Taubaté ${ }^{9}$, e algumas se perderam ao longo dos anos. ${ }^{10}$ 


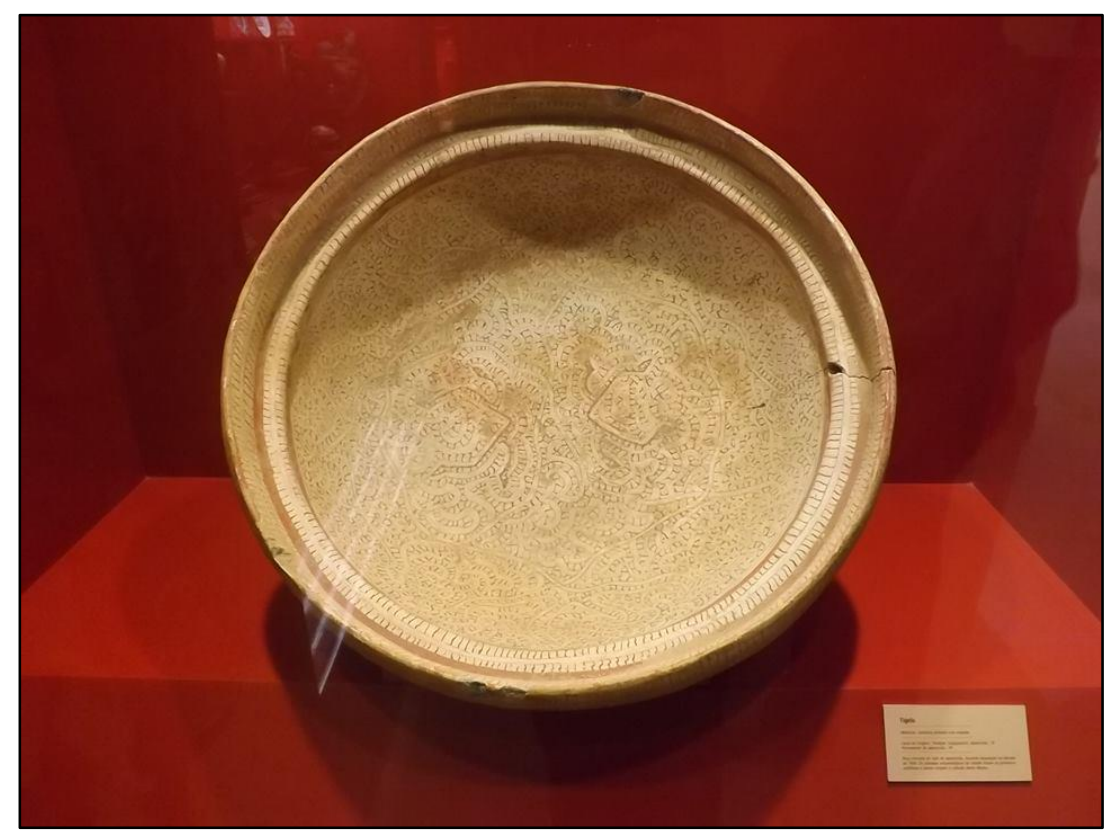

Figura 2: Vasilha cerâmica encontrada por Conceição Borges Ribeiro em Aparecida. Atualmente a única peça do acervo arqueológico em exposição ${ }^{11}$

Ainda neste período, destaco a importância das pesquisas de Manuel Pereira de Godoy na região da bacia do rio Mogi Guaçu. Este pesquisador foi responsável pela formação de extensos acervos arqueológicos que vem alimentando pesquisas acadêmicas e revelando importantes facetas da ocupação indígena no estado de São Paulo.

Godoy identificou sítios arqueológicos em alguns municípios desta região, entre eles Porto Ferreira e Rio Claro, onde o aponta para a presença de sítios com sepultamentos, como é possível notar no mapa produzido pelo autor (Figura 3).

\footnotetext{
${ }^{8}$ Informações levantadas no acervo documental do Museu de Arqueologia e Etnologia (MAE/USP) no que se refere ao Museu Paulista.

${ }^{9}$ Informações cedidas pelo curador do MNSA, César Maia, em comunicação pessoal.

${ }^{10} \mathrm{Em}$ contato com as instituições supracitadas, no entanto, a informação que tive foi que estas peças não integram seus acervos e não se sabe onde estão.

${ }^{11}$ Foto de Marcel Lopes.
} 


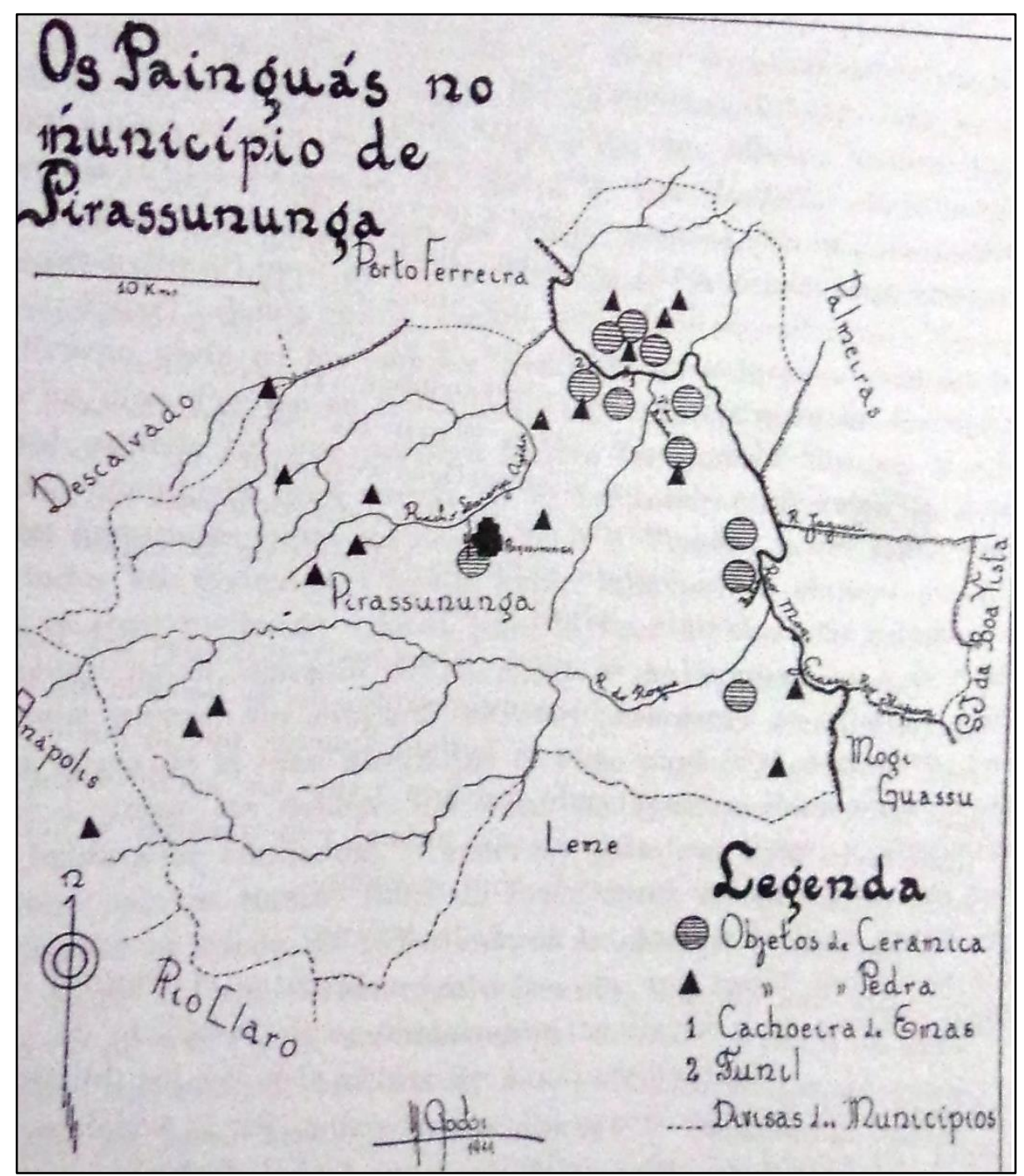

Figura 3: Mapa manuscrito de Manuel Pereira de Godoy apontando para sítios arqueológicos na bacia do Mogi Guaçu ${ }^{12}$

O trabalho desempenhado por Godoy entre 1944 e 1963 na identificação, registro e estudo de artefatos arqueológicos é de suma importância para a composição de um quadro arqueológico regional. Em seu livro "Contribuição à História Natural e Geral de Pirassununga", publicado em três volumes, o autor demonstra grande interesse em trabalhar detalhadamente a história de Pirassununga, considerando seus aspectos naturais e sociais com ampla perspectiva temporal, dedicando um capítulo inteiro no Volume 1 à presença de grupos indígenas na região de Pirassununga, no qual se apoia na arqueologia como ferramenta para uma construção histórica de longa duração dessas populações.

\footnotetext{
${ }^{12}$ Mapa retirado do artigo "Los extinguos painguá de la cascada de Emas (Estado de São Paulo - Brasil)" (1946).
} 
No que compete aos estudos de vasilhas pintadas, as contribuições de Godoy seguem em dois sentidos, o primeiro na iconografia, uma vez que o autor desenhou minuciosamente uma quantidade significativa de motivos identificados em sua coleção particular, o segundo consiste nas análises químicas dos pigmentos utilizados nas pinturas (GODOY, 1974).

Outro pesquisador importante foi José Anthero Pereira Junior, que atuou fortemente na divulgação dos achados arqueológicos no norte de São Paulo, identificando a presença de cerâmicas Tupi e outras sem pinturas ou tratamento plástico no município de Franca, as quais foram posteriormente identificadas como pertencentes à tradição Aratu (MORAES, 2007). Também publicou sobre achados arqueológicos em Itapeva, Peruíbe e em alguns bairros da capital paulista (PEREIRA JUNIOR, 1964b, 1965).

Em seus artigos descreveu as peças encontradas detalhadamente (dimensões, morfologia e aspectos decorativos) além de apresentar desenhos e fotografias dos achados arqueológicos.

"Vale lembrar que, a atuação de pesquisadores como Pereira Junior e
Manuel Pereira de Godoy, foi importantíssima ao proporcionar um
aumento considerável de coleções e de artigos sobre o tema, além de
apresentar interpretações inovadoras, seja propondo áreas onde teriam
ocorrido contatos entre grupos ceramistas diferenciados (Pereira Júnior)
ou colocando novas abordagens analíticas da cultura material (Godoy)"
(MORAES, 2007: 23).

Este momento da arqueologia pode também ser caracterizado pela preocupação com a preservação dos vestígios e sítios arqueológicos, cuja destruição vinha acontecendo de forma acelerada, um fator ainda mais preocupante com a carência de pesquisadores especializados nesta área em todo o território brasileiro.

"Diferentemente das outras ciências sociais no Brasil, a arqueologia
surgiu dentro das universidades, não através de projetos intelectuais
específicos, mas a partir de campanhas preservacionistas, promovidas
por alguns poucos intelectuais indignados com a destruição acelerada
dos sítios arqueológicos e a falta de profissionais especializados para
resgatá-los" (BARRETO, 1999/2000: 40 - grifo meu).

Esta preocupação influenciou, na segunda metade do século $X X$, uma nova fase nas pesquisas arqueológicas brasileiras, marcada pela atuação de pesquisadores estrangeiros que influenciaram a consolidação da arqueologia enquanto ciência. 
Neste período é marcante a atuação do jornalista Paulo Duarte, que buscava a valorização e preservação de bens patrimoniais atrelada à ampla difusão da cultura. Sua relação com a arqueologia, bem como com os povos indígenas, é resultado da influência de seu contato com o etnólogo francês Paul Rivet e dos cursos que frequentou no Musée de l'Homme em Paris, onde passou algum tempo exilado pelo governo Vargas ao final dos anos 1930 (SANABRIA, 2011).

Ao retornar ao Brasil, Duarte atuou fortemente na cena pública institucional a favor do desenvolvimento de pesquisas arqueológicas ${ }^{13}$ e foi responsável pelas primeiras pesquisas arqueológicas sistemáticas no Brasil, tendo como foco os sambaquis do litoral paulista, desenvolvidas com a colaboração de Paul Rivet que chega ao Brasil a convite do jornalista. Segundo Barreto (1999/2000), a vinda de Rivet para o Brasil faz parte de um projeto científico mais amplo que abrange missões acadêmicas em todas as ciências humanas.

Neste contexto, a convite de Rivet, chegam ao Brasil o casal de americanistas Annette Laming e Joseph Emperaire, que se destacaram pela introdução de métodos rigorosos de escavação, aplicado na maioria das vezes em sítios pré-cerâmicos, como os sambaquis no Paraná e os estudos de sítios líticos de Lagoa Santa (BARRETO, 1999/2000).

\begin{abstract}
"Na bagagem metodológica trazida para o Brasil pelo casal estavam fatalmente os ensinamentos de mestres como Leroi Gourhan aplicados ao contexto de sítios paleolíticos franceses. Assim, no Brasil, a escolha de sítios pré-cerâmicos é privilegiada, concentrando-se em métodos de escavação de superfícies amplas para a reconstrução de solos de ocupação de determinados sítios, e na análise de artefatos, essencialmente líticos, dentro das tipologias e terminologias francesas da época" (Ibid, p. 42).
\end{abstract}

A metodologia francesa influenciou mais tarde os trabalhos de muitos pesquisadores, entre eles a arqueóloga Luciana Pallestrini que adapta o método

\footnotetext{
${ }^{13}$ Duarte foi responsável pela criação da Comissão de Pré-História (1952), e do Instituto de Pré-História e Etnologia (1957), ambas em São Paulo. O jornalista foi também um dos fundadores do Instituto de PréHistória da Universidade de São Paulo (1962) (ALCANTARA, 2008), uma das instituições que dá origem ao atual MAE/USP, criado em 1989 a partir da fusão do antigo Museu de Arqueologia e Etnologia do Instituto de Pré-História, dos setores de arqueologia e etnologia do Museu Paulista e do Coleção Plínio Ayrosa do Departamento de Antropologia da Faculdade de Filosofia Letras e Ciências Humanas da USP. Sua militância em prol do patrimônio arqueológico está presente ainda hoje nas pesquisas desenvolvidas em todo o território brasileiro a partir da lei 3.924 de 26 de julho de 1961, a qual aponta os parâmetros definidores de patrimônio arqueológico nacional e sua preservação, aprovada graças aos esforços de Duarte (SANABRIA, 2011).
} 
de Leroi-Gourhan aos sítios cerâmicos estudados no oeste paulista no âmbito do Projeto Paranapanema (Proj Par). Segundo Faccio e Lopes (2005):

"A metodologia da escola francesa oferece os instrumentos necessários à resolução de alguns questionamentos a respeito dos grupos pregressos que habitaram o sítio, permitindo que se ultrapasse a mera caracterização dos objetos, do ambiente e a descrição do trabalho de escavação. Ela pressupõe uma abordagem mais teórica e permite uma discussão dos conceitos de território e territorialidade, aplicados à arqueologia" (Ibid., 45).

Os trabalhos desenvolvidos no âmbito do ProjPar tiveram início em 1968 a partir de pesquisas desenvolvidas em um único sítio arqueológico, o sítio Fonseca, localizado no município de Itapeva. A partir daí Pallestrini desenvolve o Projeto Paranapanema, expandindo a área de pesquisa e abrangendo uma grande extensão do Vale do Paranapanema do lado paulista.

"O Projeto Paranapanema tem por objetivo o levantamento da PréHistória de uma área de, aproximadamente, $47.300 \mathrm{~km}^{2}$, o que representa quase $20 \%$ do território do Estado. Num sentido geológico, pode-se frisar que a área do Projeto abrange trechos bastante diversificados, fato que proporcionou diferentes formas de aproveitamento das matérias-primas disponíveis nos arcabouços geológicos locais: a evidenciação precisa de artefatos líticos e cerâmicos nos espaços habitacionais decorrentes da ocupação pré-histórica de sítios situados em províncias geológicas diferentes tem corroborado tal afirmação" (MORAIS, 1981: 142).

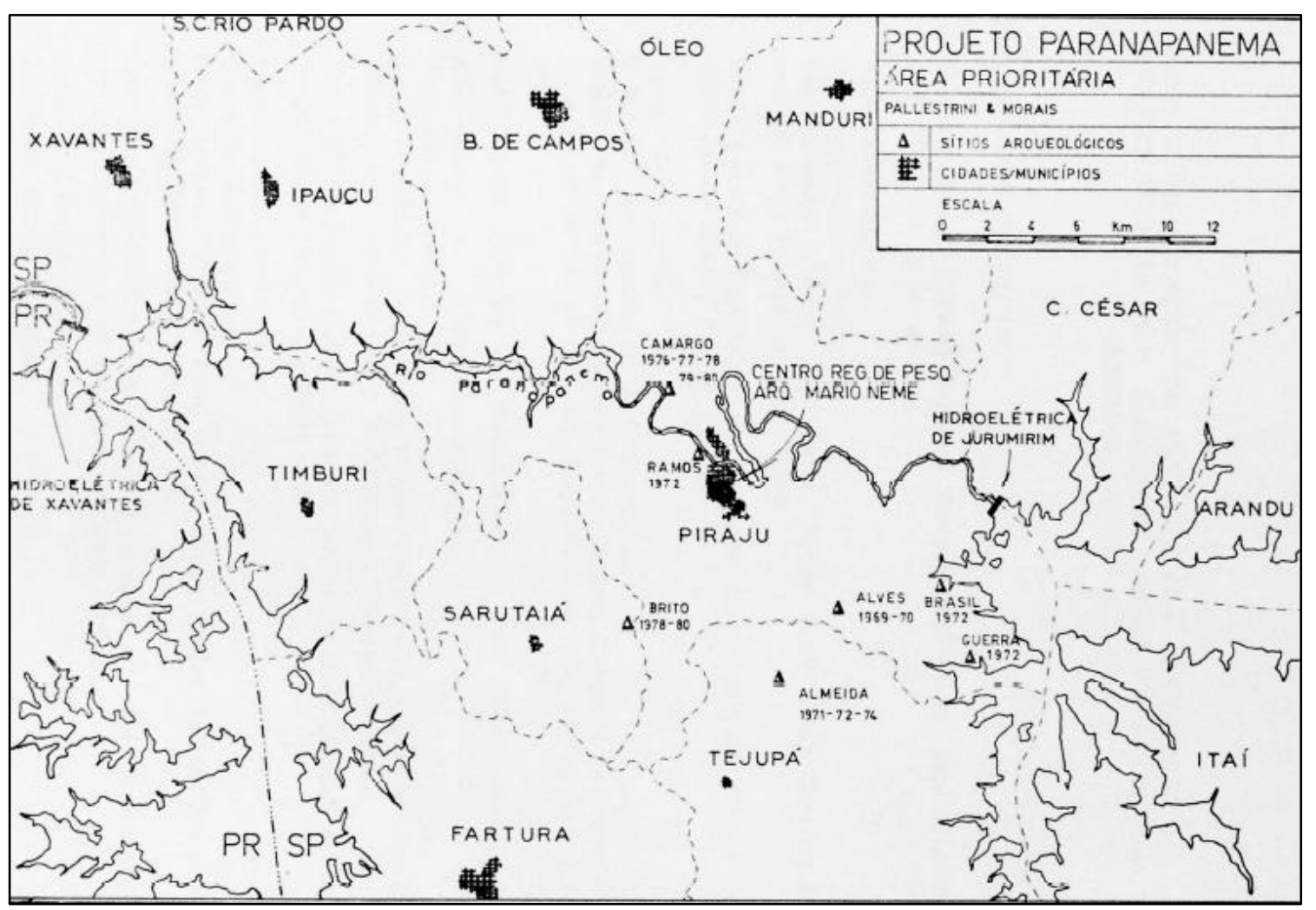

Figura 4: Plano Cartográfico do Projeto Paranapanema, Morais, 1995 
Oficialmente o Projeto passa a ser desenvolvido em 1969 com atividades que se concentraram no sítio Alves, situado no município de Piraju, sendo expandido posteriormente para outros municípios da bacia do Paranapanema, evidenciando uma série de sítios arqueológicos associados à ocupação de povos indígenas de matriz cultural Tupi.

Entre os anos 1987 e 1992 já sob coordenação de José Luiz Morais, do então Museu Paulista, hoje Museu de Arqueologia e Etnologia da USP, iniciam-se uma série de levantamentos arqueológicos e ambientais na área de abrangência do Projeto, culminando com a implantação de vários projetos especiais de salvamento arqueológico nas áreas impactadas por empreendimentos hidrelétricos (MORAIS, 1999: 44).

O novo quadro de pesquisas no âmbito do Proj Par aponta para as necessidades de novas parcerias, por sua vez estabelecidas com a Faculdade de Ciências e Tecnologias de Presidente Prudente (FCT/UNESP) e com a CESP, a fim de se constituir um Projeto multidisciplinar e interinstitucional (MORAIS, 1999). Segundo o autor

"A nova postura, além de fomentar o enfoque das relações intersítios, privilegiou o reconhecimento e a análise das estratégias de exploração, conservação e degradação do meio ambiente pelas comunidades indígenas pré-coloniais no decorrer de ciclos de desenvolvimento sócioeconômico, cultural e tecnológico" (MORAIS, 1999: 44).

O Projeto sem dúvida colaborou para o fortalecimento da arqueologia regional com a criação do Centro Regional de Pesquisas Arqueológicas de Piraju $^{14}$ (Lei Municipal $n^{\circ} 715$ de 10 de dezembro de 1970) a partir da parceria entre Museu Paulista da Universidade de São Paulo e Prefeitura Municipal de Piraju, e do Museu de Arqueologia de lepê (MAI) (Lei Municipal n.ํ 080/2000 de 10 de janeiro de 2000) a partir de parceria entre FCT/UNESP e Prefeitura Municipal de lepê, instituições que guardam atualmente grande parte do acervo gerado no âmbito do ProjPar.

Vale ressaltar que, diferente do CRAA, a história do MAI não está exclusivamente atrelada ao ProjPar. Sua trajetória começa em 1992 com uma doação Roberto Ekman Simões à FCT/UNESP. A doação consistia em três caixas de material cerâmico proveniente de sua fazenda, hoje alagada pela Usina Hidrelétrica Capivara. Este entusiasta da arqueologia identificou cinco sítios 
arqueológicos em sua propriedade e, como o apoio da FCT/UNESP e de Neide Barrocá Faccio, professora desta instituição, apoiou e participou de escavações arqueológicas no município de lepê.

"As pesquisas realizadas pela equipe da FCT-UNESP, sob a
coordenação da arqueóloga Dra. Neide Barrocá Faccio, em 16 sítios
arqueológicos do município, possibilitaram o resgate de
aproximadamente 40 mil objetos referentes à cultura material dos índios
Guarani. São recipientes de argila, lâminas de machado de pedra,
polidores, pontas de flechas, boleadeiras, adornos, potes cerâmicos,
pedras lascadas e polidas, utilitários em geral e urnas funerárias, entre
as quais, está uma das maiores urnas funerárias indígena Guarani do
Brasil com 1,16 m de diâmetro" (Informações disponíveis no site oficial
do museu ${ }^{15}$ ).

Concomitantemente ao Poj Par, com atuação em nível nacional, o PRONAPA (1965-1970) foi criado com apoio da então Secretaria do Patrimônio Histórico e Artístico Nacional (SPHAN) e do Instituto Smithsonian.

O Programa, coordenado pelos professores Betty Meggers e Clifford Evans, trouxe um avanço considerável para as pesquisas arqueológicas no Brasil, com estudos exaustivos de grande número de sítios e acervos arqueológicos a fim de estabelecer categorias classificatórias a partir de dados cronológicos (alcançados por métodos de datação absoluta) e tipológicos (DIAS, 1995).

A atuação do PRONAPA foi intensa em muitos estados brasileiros, porém o mesmo não ocorreu no estado de São Paulo. Contudo, os padrões classificatórios propostos pelos pronapianos são muito fortes na arqueologia brasileira e contribuíram muito para que outros pesquisadores realizassem pesquisas em terras paulistas, sobretudo no que diz respeito à chamada "Tradição Tupiguarani".

Segundo Moraes (2007), os poucos trabalhos desenvolvidos em São Paulo no âmbito do PRONAPA foram de autoria dos pesquisadores Fernando Altenfelder, Silvia Maranca e Igor Chmyz. Este último trouxe contribuições no campo teórico e metodológico na arqueologia como um todo a partir da proposta de elaboração de uma terminologia unificada para material cerâmico, possibilitando assim estudos comparativos entre materiais distintos (CHMYZ, 1966).

Altenfelder atuou na porção centro-leste do estado de São Paulo, região drenada pelos rios Corumbataí e Piracicaba, afluentes da margem direita do rio

${ }^{15} \mathrm{http}: / /$ museuiepe.blogspot.com.br/p/mai.html 
Tietê, desenvolvendo pesquisas arqueológicas do final da década de 1950 até os anos 1960 como professor da Faculdade de Filosofia Ciências e Letras de Rio Claro. Em 1966 o autor se insere oficialmente no PRONAPA, realizando um extenso projeto de levantamento de sítios arqueológicos, mas não permanece vinculado ao mesmo por muito tempo. Este projeto, cujas etapas de prospecção foram desenvolvidas entre 1965 e 1967, sob coordenação de Tom O. Miller Jr, abrangeu os municípios de Rio Claro, Ipeúna, Charqueada, Itirapina, Cordeirópolis e Piracicaba, resultando na identificação de 97 sítios arqueológicos (ARAUJO, 2001), dos quais a maioria indicavam a presença de grupos caçadores-coletores.

Segundo Araujo (2001), que realiza uma síntese do panorama arqueológico da região de Rio Claro, os sítios identificados por Altenfelder e Miller Jr apontavam para três horizontes temporais.

\begin{abstract}
"Altenfelder coloca tentativamente uma cronologia baseada nos dados disponíveis a época: um nível pré-cerâmico antigo, que seria datado entre 5.000 e 3.000 anos AP, contendo apenas material lítico; um nível pré-cerâmico mais recente, entre 3.000 e 1.000 anos AP, apresentando artefatos polidos; finalmente, o nível cerâmico, entre 1.000 AP e a época da colonização europeia" (ARAUJO, 2001: 129).
\end{abstract}

O nível cerâmico apontava para dois horizontes culturais: um representado por sítios com cerâmicas espessas, com decorações plásticas e/ou policromia, associadas à tradição Tupiguarani, e outro por sítios, que se apresentavam em menor quantidade, com cerâmicas mais finas e de coloração escura, mais tarde associadas à tradição Itararé, que por sua vez está associada aos povos indígenas de língua Jêêt

Mesmo tendo se dedicado prioritariamente ao estudo dos sítios líticos, Altenfelder realizou coletas de material cerâmico associado à Tradição Tupiguarani.

\footnotetext{
"No município de Rio Claro foram detectados 06 sítios arqueológicos Tupiguarani, 05 deles localizados no bairro Vila Paulista e um localizado no bairro Prema, sendo este último alvo de cortes estratigráficos. Em Rio Claro também foram recuperadas 03 urnas fragmentas. Em ambos os casos o autor chama a atenção para o predomínio das decorações pintadas" (MORAES, 2007: 43).
}

\footnotetext{
${ }^{16}$ Não pretendo neste trabalho me aprofundar na aproximação entre cerâmica arqueológica da tradição Itararé e povos indígenas de matriz cultural Jê, no entanto, para os interessados no debate, ler "A tradição cerâmica Itararé-Taquara: características, área de ocorrência e algumas hipóteses sobre a expansão dos grupos Jê no sudeste do Brasil" (ARAÚJO, 2007) e "Os caçadores-ceramistas do sertão paulista: um estudo etnoarqueológico da ocupação Kaingang no vale do rio Feio/Aguapeí” (RODRIGES, 2007).
} 
De maneira geral, a atuação de Altenfelder e Miller Jr. teve relevância no campo arqueológico e histórico do estado de São Paulo, uma vez que seus trabalhos indicam a presença de povos indígenas de diferentes matrizes culturais, o que mais tarde veio a fomentar pesquisas que apontam para o estado de São Paulo como "terra de fronteiras" (MORAIS, 2002; AFONSO, 2005; MORAES, 2007). Seus trabalhos contribuíram mais para a formação de um considerável acervo bibliográfico sobre a arqueologia regional do que para a formação de coleções arqueológicas, uma vez que tais pesquisadores não realizaram escavações sistemáticas nos sítios identificados.

“(...) trabalho de escavação implica na destruição (...) e somente deve ser realizado (...) para salvá-lo [o sitio] de uma destruição já iniciada ou inevitável, ou para responder um problema específico que não poderá ser resolvido de outra forma" (ALTENFELDER, 1968: 158).

Silvia Maranca também desenvolveu importantes trabalhos no estado de São Paulo sob orientação do PRONAPA, contudo, seu projeto mais significativo no estado consiste em pesquisas desenvolvidas no Baixo Vale do Rio Tietê em decorrência da construção da Usina Hidrelétrica de Ilha Solteira nos anos 1970. Segundo a autora, prospecções realizadas na área do empreendimento apontaram para a presença de 8 sítios arqueológicos (denominados pela autora como aldeamentos), a maioria apresenta vestígios líticos e cerâmicos com predominância de cerâmica, associado pela autora à tradição Tupiguarani. Dos sítios identificados, quatro foram datados por termoluminescência, cujos resultados apontam para ocupações entre 2200 e 1040 A.P. (MARANCA et al., 1994).

Vale a pena apontar que, nos anos 1980, um convênio estabelecido entre Companhia Energética do Estado de São Paulo (CESP) e Museu Paulista, posteriormente Museu de Arqueologia e Etnologia, ambos pertencente à Universidade de São Paulo, possibilitaram pesquisas sistemáticas nas áreas impactadas pela Usina, gerando novos dados: 26 sítios (aldeamentos) foram identificados, sendo 25 deles lito-cerâmicos e um sítio lítico (MARANCA et al., 1994).

$\mathrm{Na}$ bacia do Mogi-Guaçu, Edson Franco de Godoy ao fazer o embasamento de sua casa em 1979, encontra uma urna funerária e entra contato com o Museu Paulista. 
O sítio, denominado Franco de Godoy, associado à tradição Tupiguarani, apresenta datação de 1550 AP e contou com várias intervenções arqueológicas. A primeira delas realizada pela equipe do Museu Paulista, sob a liderança de Pallestrini, ainda em 1979. Posteriormente, o sítio foi retomado durante os estudos de doutorado de Márcia Angelina Alves (1988) e em 1992 contou com campanhas de escavações no âmbito do projeto de salvamento arqueológico da PCH-MogiGuaçu, desta vez sob a coordenação de José Luís Morais do MAE/USP (MORAES, 2007).

O último estudo realizado neste sítio consiste no mestrado de Moraes (2007), no qual "foi efetuado um diagnóstico do estado atual de conservação do sítio arqueológico, sem a realização de intervenções arqueológicas” (p. 70). A autora se dedicou ao estudo da variabilidade artefatual do sítio a partir da análise das peças coletadas nas intervenções anteriores, dialogando com os dados produzidos por Pallestrini e Morais, além de analisar o acervo particular de Edson Franco de Godoy.

O acervo arqueológico resultante das diversas intervenções ao sítio Franco de Godoy encontra-se atualmente disperso: parte salvaguardado pelo MAE/USP e parte depositado no Museu de História e Ensino "Edson Franco de Godoy", um museu particular, que já contou com apoio do poder público local e atualmente encontra-se desativado ${ }^{17}$.

A partir das informações supracitadas, é possível notar a multiplicidade de perspectivas sobre o registro arqueológico. Neste sentido, as práticas arqueológicas acadêmicas trazem inovações em teorias e métodos de pesquisa, sejam elas desenvolvidas em campo, com a escavação de novos sítios, ou ainda nos estudos que propõem revisitar coleções arqueológicas presentes em museus e instituições de pesquisa.

A densidade de registros associados à tradição Tupiguarani chama a atenção de pesquisadores, entre eles Maria Cristina Scatamacchia, que em seu mestrado (1981) reúne um quadro geral dos estudos sobre a chamada tradição Tupiguarani, a fim de unificar informações e terminologias sobre este tema. Já em

\footnotetext{
${ }^{17}$ Na ocasião de minhas pesquisas de campo para esta pesquisa, visitei o senhor Edson Franco de Godoy na expectativa de analisar suas vasilhas inteiras trazendo novas abordagens analíticas sob a perspectiva da iconografia. No entanto, o acesso às peças (quatro vasilhas inteiras) não foi possível, uma vez que o proprietário não estava com as chaves da sala onde se encontravam as vasilhas.
} 
seu doutorado (1990) a autora retoma a ideia de dispersão Tupi proposta por Brochado (1984) a fim de sistematizar dados sobre a ocupação indígena na costa brasileira entre os séculos V e XVI. A autora faz ainda algumas contribuições importantes para os estudos de iconografia com base em estudos no litoral paulista, propondo métodos de análise dos motivos pintados (MAROIS, R.; SCATAMACCHIA, M.C.M.; SERRANO, 1994) e ainda propondo estudos detalhados dos motivos pintados da cerâmica Tupi, realizando um levantamento minucioso destes motivos em todo o estado de São Paulo (SCATAMACCHIA, 2008).

Na bacia do Paraná, inicia-se em 1991, o projeto de salvamento arqueológico na área da instalação da Usina Hidrelétrica Engenheiro Sérgio Motta (Porto Primavera), localizada entre os estados de São Paulo e Mato Grosso do Sul.

A área de pesquisa, até então pouco conhecida do ponto de vista arqueológico, passou a ser explorada cientificamente com o apoio do convênio estabelecido entre a CESP e a USP, chegando a resultados interessantes:

"Com os trabalhos de campo ligados aos projetos PAPPMS e PAPPSP
foram registrados e mapeados 97 sítios arqueológicos na margem
esquerda (SP), sendo 63 cerâmicos ou lito-cerâmicos e na margem
direita (MS), 118 sítios arqueológicos, sendo 57 cerâmicos ou lito-
cerâmicos, além de uma centena de ocorrências arqueológicas"
(RODRIGUES, 2008: 132).

Ao mesmo tempo, inicia-se na região o projeto arqueológico intitulado "Décima Região", sob coordenação de Ruth Künzli, da Faculdade de Ciências e Tecnologia da UNESP (Campus de Presidente Prudente), a partir do qual foram desenvolvidos outros projetos, como o mestrado de Rodrigues (2001) tendo como enfoque o estudo da ocupação Guarani pré-colonial na região a partir dos vestígios arqueológicos, o mestrado de Rosângela, o doutorado de Emília Kashimoto (1997), o doutorado de Jean í. A. Cabrera (2015) que se debruça sobre o sítio Lagoa São Paulo 02, entre outros.

Na região central do estado, na bacia do rio Piracicaba, destaco a atuação do arqueólogo Desidério Aytai e sua esposa, Elisabeth Aytai, que realizaram escavações na região de Monte Mor (SP), tendo trabalhado com a ocupação Tupi na região, dando especial atenção aos estudos dos motivos pintados presente nas vasilhas e fragmentos encontrados (AYTAI, 1991). O casal foi ainda idealizador do 
Museu Municipal “Elisabeth Aytai”, localizado no município de Monte Mor, onde se encontram expostos os materiais resultantes de suas pesquisas.

Na bacia do Mogi-Guaçu, abrangendo também a bacia do rio Pardo, o mestrado de Moraes (2007) sobre o estudo da variabilidade artefatual da cerâmica Tupi no nordeste paulista consiste em um estudo de referência no estado. A autora aponta para a importância dos estudos da iconografia para o conhecimento das sociedades do passado, entendendo a cerâmica como um meio de comunicação social importante.

A partir de coleções variadas, algumas resultantes de salvamento em arqueologia de contrato, outras resultantes da atuação de entusiastas da arqueologia, Moraes (2007) lança mão de novos olhares sobre a ocupação Tupi no estado de São Paulo, entendida pela autora como um local de intensas relações interétnicas. Dentre as coleções resultantes de salvamento arqueológico revisitadas pela autora, destaco a pesquisa realizada no âmbito do "Programa de Resgate Arqueológico - Empreendimento Ponte de Concreto sobre o rio MogiGuaçú - Cachoeira de Emas, Município de Pirassununga, São Paulo”, pela empresa Zanettini Arqueologia em meados dos anos 2000, resultando no resgate de 4 sítios arqueológicos no município de Pirassununga, sendo o sítio Cachoeira de Emas 2 associados à tradição Tupiguarani (ZANETTINI ARQUEOLOGIA, 2006), e o trabalho de salvamento arqueológico dos sítios Água Branca, Lambari I e Lambari II, associados à duplicação da rodovia SP340, trecho Casa Branca Mococa, que apresenta um contexto arqueológico interessante e representante de ocupações de grupos indígenas Jê e Tupi nesta região (AFONSO, 2001; AFONSO \& MORAES, 2006). Moraes realiza ainda estudos de coleções particulares, como a de Manuel Pereira de Godoy e de Edson Franco de Godoy (MORAES, 2007).

Nesta mesma região, os trabalhos de doutorado (2007) de Solange Schiavetto, no qual a autora realiza atividades de campo ${ }^{18}$ e laboratório com uma proposta educativa, contribui para a formação de acervos arqueológicos com grande potencial informativo acerca da ocupação Tupi no estado.

\footnotetext{
${ }^{18}$ Entre as atividades de campo podemos destacar as coletas sistemáticas nos municípios de Rincão, Boa Esperança do Sul e São Carlos. Em ocasião de coletas no município de Rincão, a autora revisitou o Sítio Rapatoni, localizado na Fazenda Bom Retiro, município de Rincão (SP), identificado por Pallestrini na década de 1970, de onde resgatou uma urna funerária pintada, atualmente em exposição no Museu de Arqueologia e Paleontologia de Araraquara (MAPA).
} 
Também se configura como área abundante em registros arqueológicos a região banhada pela bacia do Tietê, região de Sorocaba. Segundo o museólogo e antigo diretor do Museu Histórico Sorocabano (MHS) Adolfo Friolli ${ }^{19}$, os primeiros achados arqueológicos da região remetem ao ano de 1969, ocasião em que foi encontrada uma urna funerária corrugada nas proximidades de Araçoiaba da Serra. Esta, porém foi destruída pela população local, apenas seus fragmentos foram entregues ao museu. Os achados se tornaram recorrentes nos anos que seguiram, sendo constantemente documentados pela mídia local e estadual.

No início dos anos 1990 o arqueólogo Wanderson Esquerdo Bernardo desenvolve o projeto intitulado "Gênesis Sorocabana"20, no qual realiza junto com um grupo de funcionários do MHS um intenso trabalho de mapeamento de sítios arqueológicos na região, além de realizar coletas assistemáticas em alguns bairros do município.

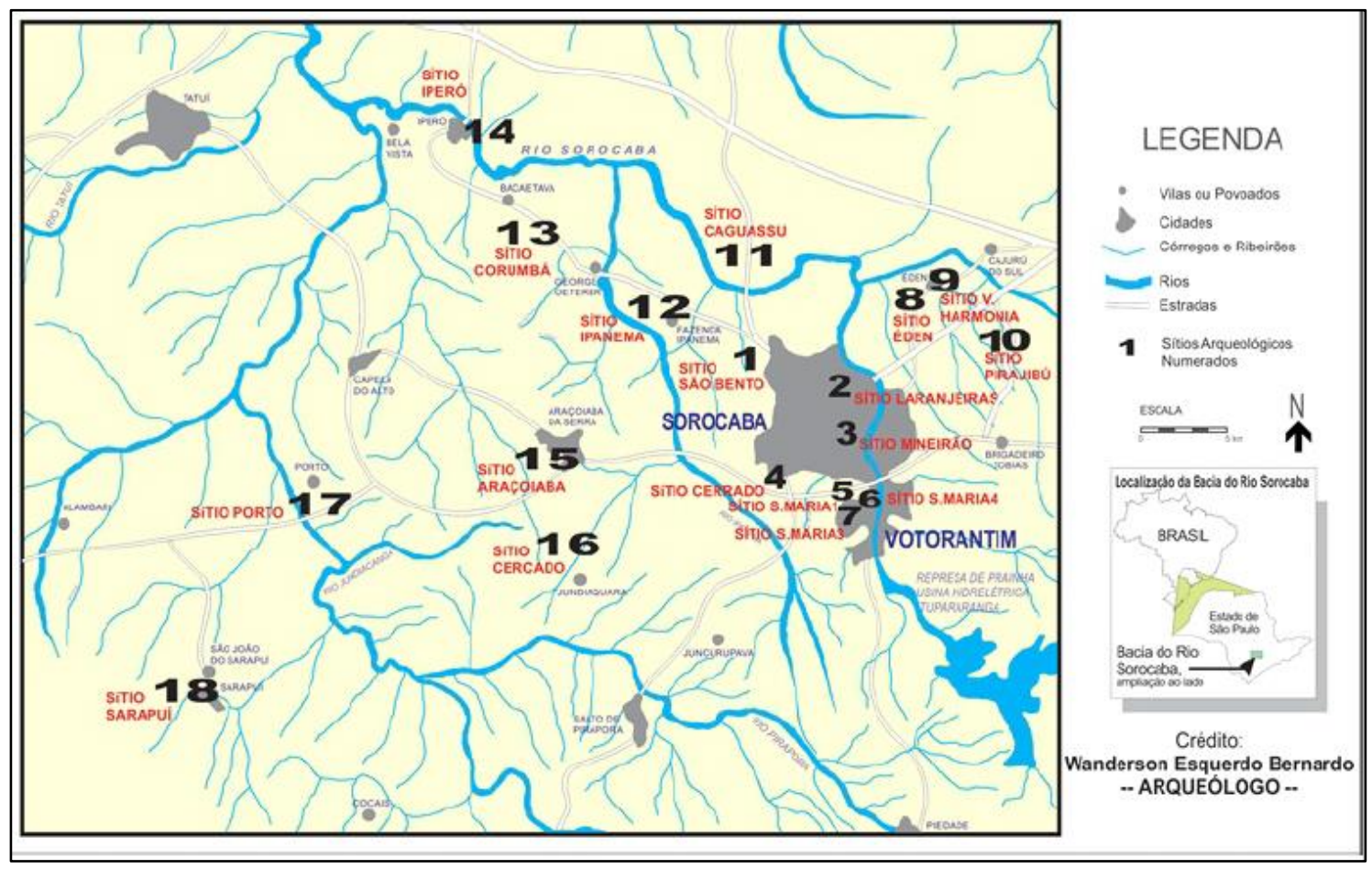

Figura 5: Mapa arqueológico da região de Sorocaba - Wanderson Esquerdo Bernardo (sem data)

\footnotetext{
${ }^{19}$ As informações sobre os diversos achados na região de Sorocaba foram registradas por Friolli em um pequeno texto que encontra-se no MHS. Além disso, a instituição conta com uma série de recortes de jornais que registraram a riqueza dos achados arqueológicos.

${ }^{20}$ As informações sobre o projeto "Gênesis Sorocabana" me foram passadas em comunicação pessoal por membros do projeto Wanderson Esquerdo Bernardo, Sônia Paes (em 2014 por ocasião de uma pesquisa de arqueologia preventiva em nome da Fundação Araporã) e por Daniella Moreira, atual museóloga responsável pelo MHS. No entanto, não encontrei no MHS relatórios ou documentos com informações mais detalhadas do projeto.
} 
Bernardo também participou de algumas pesquisas de salvamento realizadas na região. Entre elas o resgate do Sitio Pirajibu, realizada pela empresa Documento em 2000 e o resgate do Sítio Fazenda Ester, realizado pela empresa A Lasca em 2013. Estes sítios compõem atualmente o acervo do Museu Histórico Sorocabano.

Rodrigues (2012) aponta ainda para a realização de diversas pesquisas associadas à arqueologia de contrato na construção de obras municipais ou na instalação de empresas. Uma destas pesquisas, realizada no ano de 2006, resultou no resgate de uma urna funerária. Segundo o autor

"A principal concentração de sítios arqueológicos encontra-se dentro da zona urbana de Sorocaba com cinco sítios arqueológicos do período précolonial associados à Tradição Arqueológica Tupiguarani, nos bairros do Cerrado, Mineirão, Laranjeiras, Éden e Caguassu" (RODRIGUES, 2012: 35).

Ainda na bacia do rio Tietê, aponto para o trabalho desenvolvido por Marianne Sallum (2011) no sítio Gramado, no município de Brotas, Vale do Tietê SP. Este sítio foi resgatado em 1994 a partir de uma parceria entre MAE/USP e Prefeitura de Brotas, sob a coordenação de Marisa Coutinho Afonso, sendo retomado no mestrado de Sallum, que realizou análises do material cerâmico e oficinas de experimentação, tendo como objetivo "o estudo do gesto do artesão [ã], compreendido como reflexo de atitudes que refletem normas sociais" (p. 3) ${ }^{21}$

No Vale do Paraíba paulista, o trabalho desenvolvido por Marcel Lopes (2014) no sítio arqueológico Santa Maria, localizado no município de Jacareí (SP) tem o objetivo de realizar um estudo interdisciplinar, na tentativa de compreender a ocupação indígena no vale do Paraíba Paulista a partir do estudo detalhado de fontes arqueológicas, históricas e linguísticas. O sítio, identificado na década de 1970 durante a instalação de unidades industriais e de conjuntos habitacionais no município de Jacareí, contou com três etapas de pesquisa de arqueologia preventiva, desenvolvidas em 1991, 1999 e 2009/2010 (LOPES, 2014). Segundo o autor, "estas atividades resultaram na coleta de mais 20 mil peças, entre fragmentos de cerâmica e artefatos líticos, além da identificação de inúmeros vestígios, como terra preta (solo antropogênico), fogueiras, enterramentos, etc." (LOPES, 2014: 12).

\footnotetext{
${ }^{21}$ Segundo informações etnohistóricas que apresentarei mais adiante nesta dissertação, a produção cerâmica é caracterizada como atividade feminina. Logo, optei neste trabalho por me referir à "artesã(s)", no feminino, ainda que na bibliografia geral consagrada neste tema, os autores o termo no masculino.
} 
Tendo apresentado, ainda que de maneira breve, algumas pesquisas desenvolvidas no interior paulista que serviram de referência para o conhecimento do contexto histórico pré-colonial, parto agora as informações históricas que datam do período colonial aos dias atuais.

\subsection{Ocupação Tupi no estado de São Paulo: um olhar etnohistórico ${ }^{22}$}

As fronteiras e limites políticos tal qual os conhecemos hoje como municípios e estados constituem marcos territoriais recentes, delimitados a partir das relações que se estabeleceram com a chegada do colonizador.

A região que atualmente se configura como o estado de São Paulo, foco deste estudo, foi outrora ocupada por diversos grupos indígenas, que mantinham relações sociais pacíficas e/ou conflituosas entre si, a partir das quais estabeleciam seus limites territoriais.

"o que podemos considerar é que o território brasileiro tem fornecido um
extenso leque de diversidade cultural a partir de variados sistemas
sociopolíticos; uma vasta rede de comunidades inter-relacionadas com
um conjunto linguístico e demográfico de grande heterogeneidade"
(RODRIGUES, 2008: 129).

Considerando a abundância de documentos (cartas, diários de viagem, gravuras, etc.) que se dedicam à descrição das terras brasileiras, sua fauna, flora e habitantes nos primeiros séculos de colonização, é possível perceber que o interesse pela presença dos grupos indígenas, no que diz respeito ao seu modo de vida, organização social, manejo dos recursos naturais e produção material, teve início logo nos primeiros anos da situação colonial no Brasil. Porém, com o passar do tempo, o olhar do colonizador sobre essas populações foi se alterando e ganhando novas perspectivas e abordagens, até chegar nos dias atuais em que se busca uma aproximação entre saberes científicos e tradicionais a partir do reconhecimento do papel ativo destes povos (bem como de outros grupos historicamente excluídos) nas diversas trajetórias históricas brasileiras.

\footnotetext{
${ }^{22}$ Neste trabalho utilizo a etnohistória como um método de pesquisa que consiste em utilizar fontes diversas como documentos, fotografias, objetos e textos etnográficos para criar narrativas históricas que coloquem os grupos nativos enquanto sujeitos históricos, propondo uma análise interdisciplinar de suas fontes a partir de uma visão crítica, que almeja criar uma narrativa histórica que seja "completa” (Eleonor LEACOCK, 1961), ou seja, que inclua a participação das diversas culturas humanas.
} 
Diante do cenário delineado, busco apresentar neste tópico, alguns documentos produzidos sobre povos indígenas ao longo de cinco séculos de contato entre índio e não-índio, com o objetivo de juntar algumas peças deste enorme quebra-cabeças que é a história do Brasil.

Antes de me concentrar nos documentos produzidos sobre os povos indígenas sob a perspectiva do colonizador nesses cinco séculos de dominação, preciso ressaltar a importância da história oral, sobretudo aquela contada pelos povos indígenas na composição de um cenário etnohistórico. No entanto, me concentro aqui no estudo e na leitura crítica dos documentos escritos, figuras e fotografias produzidas a partir do olhar do não-índio, uma vez que estes são fontes abundantes e de fácil acesso, além de possibilitar uma viagem nos valores e perspectivas do colonizador ao longo do tempo.

O que se tem de conhecimento a respeito dos povos nativos no primeiro século de colonização é fruto de produções literárias destinadas à descrição das novas terras para que a Coroa, Clero e outros interessados que desejavam conhecer (e explorar) "novo mundo". Este período foi marcado pela produção de cartas, crônicas de viagens e relatos de jesuítas que, em contato com os povos nativos, colhiam importantes informações sobre a ocupação de grupos indígenas e sobre as relações estabelecidas entre o sujeito colonizador e o outro "nativo", cujos hábitos Ihes pareciam selvagens.

“(..) as primeiras descrições dos habitantes das terras paulistas, já no
início do século XVI, foram feitas pelos europeus que chegaram ao litoral
e, posteriormente, ocuparam o planalto de Piratininga. O misto de
fascínio e horror causado por este primeiro "encontro", descrito em
crônicas quinhentistas, como as de Hans Staden, Jean de Léry, Gabriel
Soares de Sousa, André Thevet, dentre outros, permite-nos compreender
que, após a ocupação do planalto de Piratininga, a entrada para o sertão
desconhecido levaria o europeu, sem dúvidas, a confrontar-se com
povos indígenas das mais variadas etnias" (RODRIGUES, 2014: 60).

Como foi apontado por Rodrigues no trecho supracitado, datam deste período as crônicas de Hans Staden e Jean de Léry, que se tornaram uma referência para estudos de populações Tupi no litoral sudeste.

Staden, um viajante alemão, passa pelo Brasil em duas ocasiões: a primeira delas em 1546 pelo litoral nordeste, a segunda em 1550 pelo litoral sul/sudeste, região que viria a pertencer mais tarde aos estados de Rio de Janeiro e São Paulo, então capitania de São Vicente. 
Suas experiências, narradas em primeira pessoa, exaltando seus sentimentos e sensações como prisioneiro dos Tupinambá ${ }^{23}$, foram publicadas pela primeira vez na Alemanha em 1557, anunciada na época como a

\begin{abstract}
"História Verídica e descrição de uma terra de selvagens, nus e cruéis comedores de seres humanos, situada no Novo Mundo da América, desconhecida antes e depois de Jesus Cristo nas terras de Hessen até os dois últimos anos, visto que Hans Staden, de Homberg, em Hessen, a conheceu por experiência própria, e que agora traz a público com essa impressão" (Título da primeira publicação dos relatos de viagem de Staden, 1557).
\end{abstract}

O viajante passou pelas terras de Bertioga, localizada, segundo ele, a cinco milhas de São Vicente, na região de Bertioga, atualmente conhecida como Baixada Santista. O local consistia em uma importante zona de conflitos interétnicos, que envolviam não apenas povos nativos, mas também os colonizadores, sendo os Tupinambás (na porção norte) filiados aos franceses, os Tupiniquins (na porção central) filiados aos portugueses e, por fim, os Carijós (na porção sul) filiados aos espanhóis.

"Os portugueses que vivem ali [em São Vicente] são amigos de uma tribo
dos brasileiros, os Tupiniquins, cujo domínio se estende por cerca de
oitenta milhas para dentro da terra e cerca de quarenta milhas ao longo
da costa. Ao norte e ao sul moram inimigos dessa tribo. Os inimigos ao
sul são os Carijós, e ao norte, os Tupinambás. Estes últimos também são
chamados de Tabajaras pelos seus inimigos, o que simplesmente quer
dizer 'inimigo"' (STADEN, 2011: 44). O francês Jean de Léry, outro cronista de referência para o conhecimento das populações Tupi da costa brasileira, relata em sua obra "Viagem à Terra do Brasil', intitulada em sua primeira versão, impressa em 1578, como:

"Narrativa de uma viagem feita à terra do Brasil, também dita América, contendo a navegação e coisas notáveis vistas no mar pelo autor: a conduta de Villegagnon naquele país, os estranhos costumes e modos de vida dos selvagens americanos; com um colóquio em sua língua e mais a descrição de muitos animais, plantas e demais coisas singulares e absolutamente desconhecidas aqui, cujo sumário se verá dos capítulos no princípio do livro. Tudo colhido no próprio lugar por Jean de Léry, natural de La Margelle, Saint-Seine, ducado de Bourgogne. La Rochelle, Antoine Chuppin, $1578-$ I vol. in $8^{\circ}$ com gravuras sobre madeira, uma das quais repetida" (Título da primeira publicação dos relatos de viagem de Léry, 1578).

\footnotetext{
${ }^{23}$ Devo lembrar que o etnônino Tupinambá é atribuído na bibliografia histórica (e mesmo arqueológica) para designar diversos grupos indígenas de matriz cultural Tupi que ocupavam a costa do atual Brasil. Já entre viajantes e missionários havia o reconhecimento de grupos diversos, muitas vezes com relações belicosas, ainda que possuíssem a mesa matriz cultural, como é possível observar nos relatos de Abbeville (1874) em sua passagem pelo Maranhão "Emborasejam da mesma Nação e tenham o mesmo nome de Tupinamba, o Diabo o atiça uns contra os outros a ponto de uns comerem os outros” (p. 303).
} 
Em suas viagens Léry passa pelas terras do atual estado do Rio de Janeiro, onde conviveu com Tupinambá, relatando seus costumes e práticas cotidianas, incluindo dois cânticos em língua Tupi, o mais antigo registro escrito de uma língua indígena brasileira.

Embora o autor descreva experiências vividas em terras fora do foco de estudo desta dissertação, sua obra me chama atenção pelo cuidado e atenção ao descrever a imagem e as atividades femininas na produção oleira.

"As mulheres, a quem cabe todo o trabalho doméstico, fabricam muitos
potes e vasilhas de barro para guardar o cauim; fazem ainda panelas
redondas ovais, frigideiras e pratos de diversos tamanhos e ainda certa
espécie de vaso de barro que não é muito liso por fora mas tão
completamente polido por dentro e tão bem vidrado que não fazem
melhor os nossos oleiros" (LÉRY, [1578] 1961: 186-187).

Entre os séculos XVI e XVIII, são importantes os relatos criados a partir de missões religiosas, entre elas a mais conhecida é aquela desenvolvida por Jesuítas filiados à Companhia de Jesus, que se instalaram em diversas regiões do Brasil, sobretudo no Sul ${ }^{24}$, onde estabeleceram pequenas unidades territoriais conhecidas como "reduções" ou "missões". Nestes espaços, entendidos como partes de um sistema unificado, os Jesuítas tinham como objetivo principal a "catequese", que por sua vez, tinha como função domesticar os povos indígenas, tornando-os sedentários e aptos ao trabalho agrícola.

"aos olhos dos paulistas essas missões se apresentavam como uma
mercadoria que poderia ser facilmente aprisionada. Ao entrarem nelas,
os paulistas mataram, queimaram e saquearam seus bens: gado,
adornos de igrejas e ferramentas, e escravizaram os índios
catequizados" (MANO, 2009: 31).

Ainda neste período, entre os séculos XVII e XVIII, uma série de movimentos expansionistas, conhecidas como bandeiras/entradas e monções, buscava a ampliação ${ }^{25}$ do território até então desconhecido.

"Com o século XVII começa a grande era das bandeiras paulistas. Com ele enceta o Brasil, que amanhecia, a sua penetração definitiva Brasil adentro. O núcleo piratiningano, pião deste movimento, já compreendia, além dos poucos reinóis, numerosos euro-americanos, uns e outros ávidos de aventuras selváticas" (TAUNAY, 2012: 26).

\footnotetext{
${ }^{24}$ As referências acerca de reduções no estado de São Paulo são escassas e pouco confiáveis, no entanto, Almeida (2002) aponta para fazendas localizadas em Guareí e Botucatu que pertenciam a Jesuítas, onde eram mantidos, segundo o autor "índios puros". Há também o trabalho de Rosângela C. C. Thomaz (1995) que identifica sítios arqueológicos de influência jesuítica localizados à margem direita do rio Paranapanema. No entanto a autora aponta para o caráter genérico das fontes históricas sobre a presença jesuítica na ragião, o que limita as possibilidades interpretativas no campo da arqueologia.

${ }^{25}$ Para Mano (2009), os primeiros movimentos das bandeiras e monções não tinham como objetivo a expansão do território, mas o "esgarçamento das fronteiras" (p. 22), uma vez que o objetivo inicial destas práticas consistia em conhecer novas terras, não conquistá-las.
} 
Neste momento, as terras do atual estado de São Paulo eram pouco conhecidas, visto que sua exploração e ocupação efetiva pelo colonizador a oeste do estado se deram tardiamente, apenas no final do século XIX, sendo caracterizadas até o século XVIII como rota de passagem de tropeiros e bandeirantes que seguiam viagem rumo às minas de Goiás e Mato Grosso (RODRIGUES, 2014). Portanto, o que se conhecia do estado nos primeiros séculos de situação colonial se limitava à faixa litorânea e à região até então conhecida como campos [ou planalto] de Piratininga, que atualmente compreende a cidade de São Paulo, toda sua região metropolitana e alguns municípios próximos, como Piracicaba, Campinas e Jundiaí.

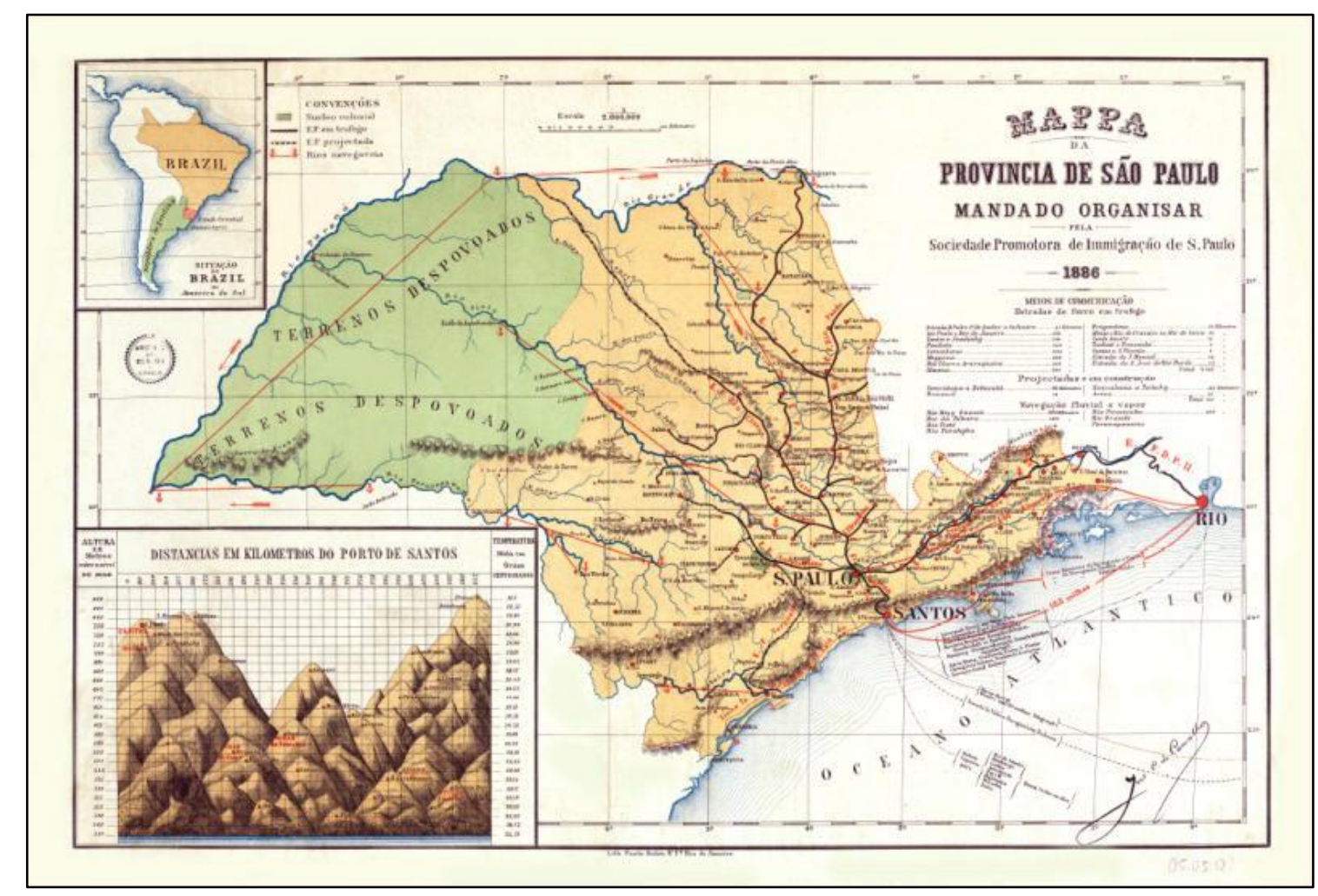

Figura 6: Mapa da Província de São Paulo promovido pela Sociedade Promotora de Imigração de São Paulo em 1886 destaca o "sertão despovoado" na região oeste do estado

Os bandeirantes ${ }^{26}$, reconhecidos na nossa história como um verdadeiro "herói nacional", que desbravou terras desconhecidas e viabilizou o avanço e o progresso, mantiveram contatos bélicos constantes com diversos povos indígenas, sendo eles mesmos, os próprios bandeirantes, mestiços, dominavam os povos nativos, fazendo-os cativos e vendendo-os como escravos.

\footnotetext{
${ }^{26}$ Não pretendo me ater ao debate sobre a ação bandeirante no estado de São Paulo, pois trata-se de um tema complexo. Para aqueles(as) que pretendem se aprofundar no tema e vê-lo sobre uma nova ótica, a partir de um olhar mais crítico, indico a leitura da obra "Negros da Terra", de John Manuel Monteiro.
} 
Assim, a relação entre bandeirantes e jesuítas era deveras conflituosa, uma vez que os primeiros capturavam os índios "domesticados" pelos religiosos, pois esses estavam aptos ao trabalho, diferente daqueles que se encontravam em terras paulistas.

A região de Sorocaba e Jundiaí, por exemplo, consiste em uma das mais antigas do estado, do ponto de vista da colonização. Já no século XVI bandeirantes instalavam ali pontos de parada para aqueles que transitavam a caminho do interior. Outra atividade que impulsionava as viagens de bandeirantes era escravidão indígena, como aponta Aluísio de Almeida (2002) em sua obra "Sorocaba: 3 séculos de história" ao citar seu estudo em livros de registro e batismo de "administrados", como eram chamados os cativos indígenas, uma vez que a escravidão indígena, também conhecida como "escravidão vermelha" era proibida pela coroa. Esta prática, encoberta ainda hoje pelo discurso histórico oficial, foi responsável pelo aumento da diversidade étnica no estado de São Paulo em período colonial, uma vez que os bandeirantes buscavam índios de outros grupos e outras localidades.

"No fim do século 17 e no seguinte, os nossos bandeirantes, conforme documentação conservada nos livros de batismo de 'administrados', trouxeram representantes das tribos gualis, bororos, parecis, e outras que não ficaram anotadas" (ALMEIDA, 2002: 15).

Segundo o autor, estes índios foram, com o tempo, se misturando à população local, dando origem ao que o autor chama de "caipira", população mestiça de brancos, negros e índios. 


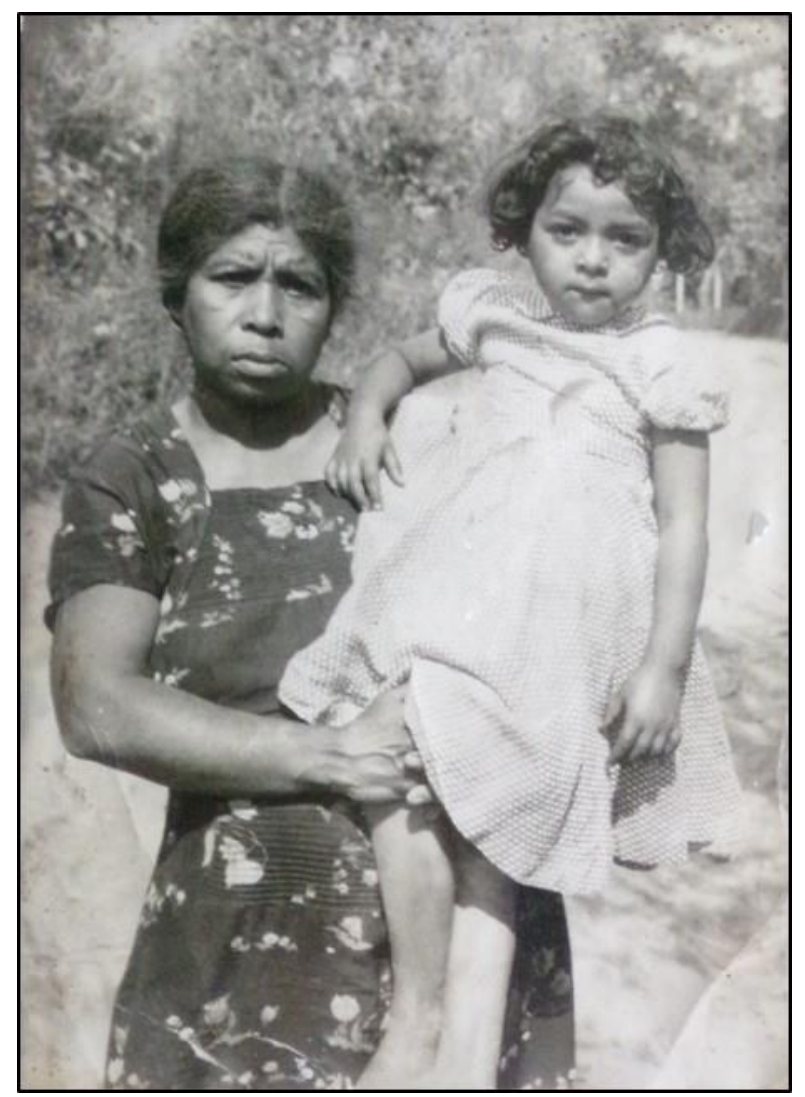

Figura 7: Últimos indígenas (sem denominação étnica) que habitaram a "Aldeia Velha de Carapicuíba". Fotografia de 1950 (Acervo MHS)

Sobre a presença e distribuição dos grupos indígenas na província de São Paulo:

\begin{abstract}
"O quadro etnográfico de São Paulo assim o desenhou Capistrano de Abreu: guaianases no interior das terras até o Espírito Santo com inserção de goitacases, de posição desconhecida, tupiniquins e tupinambás vindos posteriormente e ainda carijós ou guaranis. Pelo sertão comunicavam-se os tupiniquins com os homônimos de llhéus e Porto Seguro. Supõe o mestre que os representantes últimos do grupo venham a ser os puris desaparecidos do vale do Paraíba no decorrer do século XIX. A oeste nas terras afastadas de São Paulo dominavam os ubirajaras e bilreiros que Capistrano identifica como caiapós" (TAUNAY, 2012:22).
\end{abstract}

Na segunda metade do século XVIII e primeiras décadas do século XIX os registros bibliográficos acerca da presença indígena em todo o território nacional passam a ter, pela primeira vez, um caráter científico devido à influência do pensamento iluminista que se desenvolvia na época. A partir de relatos de viajantes naturalistas que buscavam conhecer as especificidades da fauna e flora local, este período representa os primeiros passos da arqueologia no Brasil (BARRETO, 1999/2000).

Neste contexto, a coroa Portuguesa passa a investir em expedições científicas às capitanias com o objetivo de alimentar a economia colonial a fim de recuperar a metrópole portuguesa (VARELA, 2009). No estado de São Paulo, a 
principal rota dos viajantes incluía a passagem pelo rio Tietê que corta o todo o estado, nascendo no litoral e desaguando no rio Paraná. Neste circuito, muitos naturalistas seguiam o curso do rio sentido oeste, se deparando com grande diversidade de povos indígenas.

Entre tantos naturalistas que passaram pelo estado de São Paulo, destaco a atuação de Hercule Florence, naturalista francês que viajou pelo interior do Brasil no início do século XIX, passando pelos rios Tietê e Pardo, rumo ao Amazonas. Em sua viagem, Florence realizou registros escritos e pictográficos sobre espécimes diversas, estes publicados sob o título "Viagem Fluvial pelo Interior do Brasil - 1825 a 1829" pelo Instituto Histórico e Geográfico Brasileiro (IHGB) sob tradução de Visconde de Taunay. Sobre os povos indígenas com os quais entrava em contato, Florence demonstrava interesse particular pelas pinturas corporais, as quais registrava minuciosamente. Além disso, era de interesse do autor o cotidiano em família, os objetos utilizados nas tarefas diárias e a organização social e espacial dos povos indígenas.

Foi neste período, na passagem do século XVIII para XIX que as terras até então denominadas "sertão desconhecido" passaram a ser efetivamente exploradas.

Além de alguns grupos de matriz cultural Tupi, a região que compreende o norte e oeste do estado de São Paulo era (e ainda é) povoada por povos indígenas de matriz cultural Jê, historicamente conhecidos como "Coroados" (Kaingangs). Além disso, muitos são os relatos da presença dos Guaianá, que ainda hoje não se sabe se são Tupi ou Jê.

Com base nos estudos do antropólogo Júlio Cesar Melatti, Rodrigues (2007) aponta para três frentes de expansão no oeste paulista: a frente dos criadores de gado oriundos de Minas Gerais; a frente do café e uma frente caracterizada por uma agricultura mais diversificada (p. 50), sendo o período cafeeiro no século XIX a mais intensa provocando, segundo o autor, uma procura frenética por terras no oeste paulista.

Tamanho desenvolvimento econômico e crescimento populacional trouxe a necessidade de novos meios de transporte (de produtos e pessoas). Assim, iniciase a construção de ferrovias que adentram o interior paulista. 
Kaingang, vai provocar o choque entre esse povo e a frente de expansão ocidental" (RODRIGUES, 2007: 51).

Com a intensificação dos conflitos entre indígenas e a população nãoindígena que acompanhava a frente expansionista, algumas ações estratégicas foram adotadas por parte do Estado. Uma delas consistiu na criação do Serviço de Proteção aos Índios e Localização dos Trabalhadores Nacionais (SPILTN) ${ }^{27}$, atual Fundação Nacional do Índio (FUNAI). O SPILNT foi criado em 1910 por decreto-lei o 8.072 com o objetivo de criar e garantir as políticas indigenistas que previam proteção e tutela dos índios, sobretudo àqueles em contextos de colonização recente, como foi o caso dos Kaingang e Guarani do oeste paulista.

Em seus primeiros anos de atuação, o SPI criou Postos Indígenas em diversas localidades que contavam com territórios ocupados por grupos indígenas. O objetivo era "pacificar" estes grupos, garantir sua segurança e seu direito a terra e oferecer recursos nas áreas de saúde e educação. Além disso, esta política era favorável ao trânsito dos povos indígenas no ambiente externo ao posto, desta forma, os índios seriam gradativamente incorporados na sociedade civil. Um pensamento progressista e evolucionista norteava a atuação deste e dos demais órgãos públicos, que viam a diversidade étnica brasileira como um momento passageiro. $\mathrm{O}$ fim desta diversidade aconteceria via mestiçagem e com a incorporação dos grupos indígenas na sociedade nacional.

Este processo culminou na demarcação das primeiras Terras Indígenas (Tls) brasileiras: TI Araribá (1912) no município de Avaíin, TI Índia Vanuíre (1913) no município de Arco Íris, TI Icatu ${ }^{29}$ (1916) no atual município de Arco Íris que atualmente abrigam as etnias: Guarani, Kaingang, Krenak, Terena, entre outras em menor quantidade.

\footnotetext{
27 Os dados sobre a atuação do SPI estão disponíveis no site da FUNAI <http://www.funai.gov.br/index.php/servico-de-protecao-aos-indios-spi?start=1\#>

${ }^{28}$ Sobre a demarcação da TI Araribá, ver Nimuendaju (1987).

${ }^{29}$ Sobre a demarcação das Tis India Vanuíre e Icatu ver Rodrigues (2007).
} 


\section{Capítulo 2: Base teórica para uma arqueologia crítica}

"The past, then, is gone; it can't be recaptured in itself, relived as object. It only exists now in its connection with the present, in the present's practice of interpretation" (SHANKS e TILLEY, 1987: 26).

A arqueologia, como o próprio nome sugere (do latim: archaios = antigo; logos = estudo), nasce a partir do interesse humano em compreender o passado, mas vem se reconstruindo ao longo dos anos, e hoje pode ser entendida a partir de suas múltiplas abordagens teóricas e metodológicas que buscam compreender as sociedades humanas a partir de sua produção material, sem preocupações de caráter cronológico (FUNARI, 2010).

Neste sentido, o conhecimento arqueológico pode e deve ser caracterizado como discurso, uma interpretação da materialidade a fim de problematizar aspectos sociais e simbólicos das sociedades humanas que se apresentam, de alguma forma, distantes no tempo e no espaço, deixando marcas que ultrapassaram os limites do tempo. De acordo com Ulpiano Bezerra de Menezes:

"A exterioridade, a concretude, a opacidade, em suma, a natureza física
dos objetos materiais trazem marcas específicas à memória. (...). Basta
lembrar que a simples durabilidade do artefato, que em princípio costuma
ultrapassar a vida de seus produtores e usuários originais, já o torna apto
a expressar o passado de forma profunda e sensorialmente convincente"
(BEZERRA DE MENEZES, 1998: 90).

Esta perspectiva coloca o passado como narrativa construída a partir da memória de indivíduos ou grupos e tem sido uma das bases para um movimento teórico denominado Pós-processualista, que emerge no final da década de 1970 na Europa. Tal movimento originou-se da atuação de alguns estudiosos que buscavam romper com os pressupostos teóricos e metodológicos de uma ciência arqueológica que, segundo os pós processualista, se apresentava de maneira rígida, neutra e positivista.

A nova corrente surge com uma proposta diferenciada no que compete ao campo teórico, se libertando da necessidade de limites bem definidos e assumindo a pluralidade do discurso científico das abordagens metodológicas que, segundo Shanks (2005) devem dialogar com a realidade atual. 
for its own sake than a knowledge that linked intimately with contemporary issues and interests, such as different values placed on the pas" (SHANKS, 2005: 134).

Neste sentido, as novas arqueologias do movimento "pós" propõem uma releitura da própria ideia de sociedade, até então, entendida pela arqueologia processualista como um mecanismo extrassomático de adaptação ao meio. A proposta pós-processualista, por outro lado, se apoia na ideia de que a(s) sociedade(s) consiste(m) em um meio de comunicação social, no qual os indivíduos são constituídos, ou "influenciados", por fatores externos (ambientais e sociais), mas também atuam na formação da sociedade, alterando consequentemente, o meio social e ambiental a sua volta.

\begin{abstract}
"Overall this matter of agency has been sometimes caricatured as a postprocessual search for the individual in prehistory. It is not actually about this at all, but rather about how we are to conceive of society in a way that allows its constituent people to be active and creative in reproducing and changing their society" (SHANKS, 2005: 135).
\end{abstract}

A necessidade de uma ciência arqueológica engajada pode ser entendida a partir do contexto social, político e econômico em que emerge este movimento, uma vez que é sabido que as décadas de 1970 e 1980 contaram com intensos conflitos políticos em diversos países. No caso brasileiro, esta vertente passa a ser conhecida no âmbito acadêmico na década de 1990, com o processo de redemocratização do país. A nova Constituição Federal de 1988, com apontamentos mais humanitários, passa a reconhecer os direitos políticos de minorias étnicas, como negros e indígenas. Este cenário traz à tona a necessidade de uma prática arqueológica ativa no presente, com a proposta de dialogar com grupos sociais que passam a reivindicar seus direitos políticos. Este mesmo fator trouxe mudanças nos paradigmas teóricos propostos inicialmente por esta corrente.

\footnotetext{
"What emerged in the 1990s was a modification of the initial thesis (objects as text), and a realization that (material) culture, one of archaeology's prime interests, is indeed meaningful, but meaning is inherently slippery, negotiated by makers, users, and interpreters. The words used to express this include poly semous and undecideable" (SHANKS, 2005: 140).
}

De acordo com Funari (2000), o advento de uma prática arqueológica mais humanista, já defendida por Paulo Duarte desde o período militar, vem da necessidade de ruptura com uma arqueologia "neutra" e empírica, focada apenas no desenvolvimento científico. 
Para Shanks e Tilley (1987), a seleção dos objetos a serem preservados (ou não) e estudados (ou não), produzindo assim "conhecimento" (que entendo aqui como discurso), está intrinsecamente ligada aos interesses de indivíduos ou grupos sociais. Dito isso, entendo que o caráter relativista da construção do conhecimento tem como ponto de partida, o reconhecimento de múltiplos passados.

Neste sentido, as abordagens pós-processualistas apontam para a importância da valorização dos aspectos singulares de cada cultura, retomando alguns debates já propostos pela corrente Histórico-Culturalista, somando ao fator social cultural a ação de indivíduos e suas capacidades cognitivas, que tem papel central na compreensão das dinâmicas sociais do passado e do presente.

Os(as) adeptos(as) das diversas correntes do movimento pósprocessualista entendem a cultura como algo dinâmico e fluído que entende a produção material como resultado de um conjunto de fatores: sociais, econômicos, ambientais, históricos e também individuais, uma vez que cada indivíduo é dotado de capacidade criativa, podendo gerar processos inovadores na produção material.

Assim, o estudo da diversidade étnica e cultural vem ganhando espaço na agenda científica da(s) arqueologia(s) pós-processualista(s). Os trabalhos interdisciplinares, que estabelecem o diálogo com outras áreas do conhecimento, a fim de enriquecer as pesquisas arqueológicas, vem cada vez mais ganhando destaque.

Além disso, a prática ativista e engajada de alguns pesquisadores busca integrar ao discurso científico os saberes tradicionais das pessoas que convivem diariamente com a cultura material. Esta junção de saberes tem sido o foco dos trabalhos colaborativos, que buscam romper com o caráter colonialista e unilateral, tão marcantes na história da arqueologia no Brasil e no mundo.

\footnotetext{
"Essa reflexão vem fundamentando as críticas sobre a natureza colonialista da disciplina, provocando transformações nas práticas arqueológicas. As críticas são pautadas nos questionamentos sobre os benefícios e os beneficiários das pesquisas arqueológicas, na relativização do direito e da capacidade dos arqueólogos de controlar o conhecimento sobre o passado e na eliminação da supremacia da interpretação científica em detrimento das interpretações êmicas sobre o passado" (SILVA et al., 2011: 36-37).
} 
Neste contexto, passa a ser de interesse para arqueologia também os aspectos simbólicos da(s) cultura(s), o que trazem à baila temas como decoração cerâmica e design dos objetos que antes assumiam papel secundário na arqueologia. Segundo Shanks (2005) o estudo dos aspectos subjetivos que permeiam todas as esferas sociais nos permite chegar ao potencial criativo humano e na capacidade de realizar projetos a partir de um conhecimento subjetivo. Neste sentido, a atenção despendida ao fator simbólico demonstra o interesse de uma arqueologia que se dedica ao estudo não apenas na produção e comportamento humanos, mas também no seu potencial cognitivo.

Para os críticos do movimento "pós", estes dois fatores (relatividade e ativismo científico) afastam a arqueologia do conhecimento científico, levando a arqueologia a contradição.

\begin{abstract}
"Dar ênfase à análise do discurso é, para muitos, como que proclamar a autodestruição de uma ciência que, por definição, tem como fonte primária objetos concretos que podem provar a existência de um passado [logo] se os acontecimentos do passado tornaram-se relativizados, como poderiam os arqueólogos recorrer às analogias entre passado e presente?" (SCHIAVETTO, 2003: 43).
\end{abstract}

A crítica à subjetividade na arqueologia também é direcionada aos estudos de etnicidade, pois se a própria questão da identidade étnica, segundo Barth (1969), é por si subjetiva e relacionada ao autorreconhecimento, a tentativa de constituir histórias de longa duração a partir da aproximação entre vestígio arqueológico e populações atuais seria impossível.

Tais críticas são encaradas pelos pesquisadores que defendem a prática ativista da arqueologia como a expressão de um pensamento acrítico, resultante da polarização do pensamento científico.

Diante do exposto, trago alguns conceitos e abordagens teóricas que permeiam meu trabalho e serviram como pano de fundo para as reflexões apresentadas no Capítulo 4.

\title{
2.1 Conceitos tradicionais, novas abordagens
}

Os vestígios cerâmicos tem sido o foco de muitas pesquisas arqueológicas, isso acontece devido à sua durabilidade, ampla dispersão territorial e alto 
potencial interpretativo (MORAES, 2006), uma vez que carregam aspectos importantes sobre as relações estabelecidas entre sujeitos e objetos.

Os primeiros estudos arqueológicos brasileiros se apoiavam nos pressupostos teóricos e metodológicos da escola Histórico-culturalista, se apoiando nas tipologias dos artefatos (ou seja, as caraterísticas morfológicas e decorativas) para identificar unidades socioculturais no espaço e no tempo. $O$ método adotado buscava era orientado por três perguntas básicas: "Quem?", "Onde?" e "Quando?", as quais buscavam, a partir da identificação de tipos e de informações contextuais, levantar hipóteses sobre as diversas ocupações humanas em todo o território nacional.

Posteriormente, sob influência da corrente processualista, novas questões foram inseridas ao debate arqueológico, entre elas a relação estabelecida entre sujeito e objeto que premeiam os processos produtivos.

Neste contexto, se destaca o conceito de cadeia operatória cunhado por André Leroi-Gourhan na primeira metade do século $\mathrm{XX}$, cujo objetivo inicial era compreender todas as etapas que envolviam a produção dos objetos, desde a busca pela matéria prima ideal, seleção de ferramentas e técnicas a serem empregadas no processo.

Este conceito, foi adaptado por Pierre Lemonnier, que busca compreender não apenas as etapas produtivas de confecção dos artefatos, mas também sua utilização e descarte. Neste sentido, compreender o ciclo de vida dos objetos consiste em compreender a interdependência existente entre o comportamento humano a partir das técnicas e escolhas tecnológicas ("technological choices"), e o artefato em si.

\footnotetext{
"The nature and range of such interdependence of technical behaviors with logics that are mostly "non-technical" is the subject of an enquiry which attempts to determine how and to what extent societies play with the apparently overriding laws that govern their action on the material world" (LEMONNIER, 1993: 2).
}

Para o autor há a produção e as escolhas tecnológicas estão intrinsecamente ligadas ao "estilo tecnológico". Este conceito carrega consigo a necessidade de compreender os modos de fazer, abordando as escolhas realizadas pelos(as) produtores(as) de artefatos. 
É válido ressaltar que tais escolhas não são inerentes ao processo produtivo, mas consistem em um corpo de conhecimentos passados tradicionalmente entre as gerações em um determinado tempo e lugar, representando aspectos sociais de seus (suas) produtores(as).

\begin{abstract}
"the logic and coherence of this technological knowledge - or whatever we call the information and mental operations that underlie individual action and behavior - are not related solely to the physical phenomena that are set in motion by a given technique. Social representations of technology are also a mixture of ideas concerning realms other than matter or energy. In short, the mental process that underlie and direct our actions on the material world are embedded in a broader, symbolic system" (LEMONNIER, 1993: 3).
\end{abstract}

Ao apresentar e desenvolver este conceito (de estilo tecnológico), o autor revela as dificuldades em compreendê-lo, uma vez que as escolhas realizadas pelo indivíduo não acontecem de forma arbitrária, mas são sempre orientadas por inúmeros fatores, alguns de ordem técnica [e prática], como a busca pela economia de energia, a disponibilidade matérias-primas e ferramentas adequadas, etc., mas as escolhas também são orientadas por fatores sociais e simbólicos, por exemplo o contato com outros grupos e a aprendizagem de novas técnicas de produção que possam ser incorporadas ao processo produtivo, o que influencia nas características físicas (estilo) e performance do objeto.

O estilo tecnológico e a escolha do (a) produtor (a) por sua vez, consiste em um dos elementos-chave da chamada Arqueologia Comportamental, desenvolvida pelo arqueólogo Michael Schiffer na segunda metade do século XX nos Estados Unidos. Esta corrente teórico-metodológica (um desdobramento da Arqueologia Processual) busca compreender as diversas relações sociais que permeiam os processos produtivos, entre elas a relação de ensino e aprendizado, a partir da qual o "saber fazer" (o que inclui a técnica utilizada, a escolha de matérias-primas, o gesto, etc.) é perpetuado ao longo de gerações (SCHIFFER \& SKIBBO, 1987).

Neste contexto, ganham destaque as relações de ensino e aprendizado, pois é nesta relação que os (as) produtores (as) conhecem, reconhecem e se familiarizam com os gestos, texturas e imagens que circundam o universo produtivo. Segundo Silva (2001), o aprendizado entre as populações indígenas se dá pela observação e pela prática, é desta forma que as ceramistas mais velhas ensinam o ofício às mais jovens. Segundo a autora, os processos de ensino e aprendizado perpassam pelas relações de parentesco e de gênero, uma vez que 
a produção oleira cabe apenas às mulheres, que por sua vez ensinam suas filhas e noras na mesma medida em que aprendem com suas mães, avós e sogras.

A escolha da argila, os elementos a serem adicionados até que a pasta seja ideal para a produção das vasilhas, a forma de manusear o barro, o acabamento, a pintura, como organizar as vasilhas para a queima, etc. Todas as etapas são minuciosamente aprendidas e garantem a perpetuação de estruturas sociais tradicionais.

Apenas a partir da década de 1980, com as correntes teóricas associadas ao movimento pós-processualista, os estudos estilísticos são retomados e ressignificados a partir de debates interdisciplinares que buscavam acessar os aspectos simbólicos que permeiam a produção e utilização dos artefatos. Com isso, busca-se romper com a dicotomia até então existente entre estilo e função, uma vez que, entre as populações indígenas, os objetos são concebidos em sua totalidade, não havendo distinção entre objetos "úteis" e "belos" (RIBEIRO, 1987a e b; SCHANN, 1996; SILVA, 2001; LAGROU, 2003, 2007; OLIVEIRA, 2016). Além disso, o discurso do estilo passa a integrar questões subjetivas como identidades étnicas e representatividade.

Seguindo esta linha, Polly Wiessener (1983), com base em sua pesquisa realizada entre os $\mathrm{San}^{30}$, identifica aspectos estilísticos da indústria de pontas de projétil destes povos que podem estar associados ao universo individual e coletivo. A autora estabelece duas categorias de estilos, o emblemático e o assertivo. O primeiro se relaciona com o meio social e pode ser entendido como um importante indicador de identidade social, pois o estilo emblemático seria "um emblema" do grupo, o qual pode ser percebido nas características tecnológicas e/ou decorativas dos objetos. A segunda categoria estaria relacionada ao universo do individual. Segundo a autora, os indivíduos tendem a buscar uma autoimagem positivas de si mesmos, ou seja, buscam, por meio da produção material, passar mensagens para os demais membros do grupo sobre sua identidade individual.

Peter Roe (1995), reconhecendo as limitações da prática arqueológica que se debruça sobre objetos para compreender dinâmicas sociais do passado, assume uma perspectiva interdisciplinar que parte do diálogo entre arqueologia, etnologia e arte.

${ }^{30}$ Povos indígenas na África Austral. 
O objetivo do autor é romper com a perspectiva materialista sobre o estilo, difundida na corrente processualista, que deixa em segundo plano os aspectos estilísticos e se concentra nos elementos relevantes para o desempenho funcional dos artefatos. Nas palavras do autor.

\begin{abstract}
"materialists like Dunnell (1978), drawing upon the framework of the German technologist Semper, via Boas (1955 [1927]), find style useless. Functional attributes are those relevant to evolution and selection; the residuum is style. Similarly, Binford (1962) defines style as whatever attribute is left over after all techno functional or "technomic" parameters are subtracted." (ROE, 1995:34)
\end{abstract}

Para tanto, Roe aponta para a realidade multidimensional dos artefatos, a qual abrange cinco aspectos: psicológicos (ligados à capacidade criativa); formais, sociais, míticas (relacionado às mensagens conscientes que conferem significado aos componentes) e estruturais.

\title{
2.2 Diálogos Interdisciplinares
}

Por muito tempo antropólogos(as) mantiveram sua atenção voltada para temas imateriais e subjetivos, buscando compreender as incontáveis estruturas sociais que permeiam as mais diversas relações humanas, relegando para 0 segundo plano os objetos produzidos em meio a tais relações. Apenas em meados do século XX alguns antropólogos incorporam os objetos às suas pesquisas etnográficas, debruçando-se sobretudo sobre àqueles objetos considerados, segundo o senso estético ocidental, objetos de arte (como cestarias, máscaras, adornos, entre outros objetos quase sempre associados a contextos rituais), originando o que conhecemos hoje como antropologia da arte.

A antropologia da arte configura-se ainda como um campo recente na antropologia. Segundo Els Lagrou (2003), alguns antropólogos se dedicaram ao estudo das artes não-ocidentais antes de Gell, entre eles Franz Boas (2015) e Cliford Geertz (1997). O primeiro se dedica a arte decorativa dos povos melanésios, apresentando em sua obra "Arte Primitiva" 31 a relação entre estética e técnica com o objetivo de romper com os paradigmas evolucionistas ainda presentes na antropologia da primeira metade do século XX. Boas não desvincula a arte da percepção estética, pelo contrário, o autor se concentra em elementos 
formais, como simetria e ritmo, presentes na arte de povos sem escrita. No entanto, Boas rompe com paradigmas evolucionistas ao abordar os valores estéticos como um fenômeno cultural, construído a partir de processos históricos particularidades para cada povo.

Geertz (1997) dedica algumas páginas de sua obra "O saber local: ensaios de antropologia interpretativa" ao estudo da arte como sistema cultural, propondo, segundo Lagrou (2003), uma etnografia do gosto, ou seja, o autor busca compreender como determinado povo pensa e interpreta elementos visuais, considerando que tais interpretações são resultado de um conjunto de normas estéticas (conscientes e inconscientes) que são construídas localmente. Para Geertz a arte tem papel comunicativo em cada sociedade, neste sentido, artista e observador devem compartilhar dos mesmos valores sociais e habitus ${ }^{32}$ para que a mensagem proposta por meio do objeto de arte seja transmitida de forma satisfatória.

Tais autores foram fortemente criticado por Alfred Gell (1998, 2001) que acredita que o fato dos pesquisadores supracitados voltarem suas pesquisas para objetos ritualísticos/cerimoniais (e não em objetos que circulam em atividades rotineiras) está associado ao valor estético atribuído pelo pesquisador sobre os mesmos. Para Gell antropólogo não possui as mesmas ferramentas que os artistas não-ocidentais por pertenceram a contextos culturais distintos, o que dificultaria a percepção do primeiro sobre a produção do segundo, uma vez que ambos possuem sensibilidades estéticas diversas.

Neste sentido, o problema para o desenvolvimento de uma antropologia da arte, segundo Gell, estava no próprio conceito de arte. O autor dialoga com o conceito de arte moderna, cujo valor não se limita a questão estética, que por sua vez considera arte aquele objeto que responde a determinados critérios mínimos que permitem que ele seja distinguido de outros objetos não produzidos com este fim (LAGROU, 2003: 108). A proposta de Gell vai além e abrange inclusive o papel social e técnico desempenhado pela mesma.

\footnotetext{
${ }^{32}$ Neste trabalho utilizo o conceito de habitus proposta por Pierre Bourdieu (1983), que consiste em um corpo de regras sociais (implícitas e/ou explícitas) construídas a partir de experiências individuais e que estão na base de cada sociedade, permitindo a comunicação entre sujeito e sociedade.
} 
A antropologia da arte vinculada à estética, segundo o autor, traz uma série de problemas, entre eles a oposição entre arte e artefato decorrente da classificação a partir do senso estético do pesquisador, uma vez que este conceito não é trans-cultural ou inerente ao ser humano, mas sim construído a partir de uma rede relações sociais. Gell aponta ainda para a apreciação do belo em todas as esferas sociais, desde objetos utilizados em rituais até objetos cotidianos, como a rede de caça dos Zande exposta por Suzan Vogel na exposição intitulada Art/Artifact no Cen ter for African Art em Nova lorque (GELL, 1996 ${ }^{33}$ ).

Diante disso, Gell (1998) propõe o que ele mesmo denomina a verdadeira antropologia da arte, que tem como objetivo compreender as diversas relações sociais que envolvem os objetos de arte, que podem ser de naturezas diversas, inclusive o próprio corpo humano. Neste contexto, os objetos são considerados agentes sociais, pois são capazes de iniciar um evento. Nas palavras do autor: an agent is defined as one who has the capacity to initiate causal events in his/her vicinity, which cannot be as escribed to the current state of the physical cosmos, but only to a special category of mental states (GELL, 1998: 19).

Neste sentido, o que se espera da antropologia da arte proposta pelo autor é a compreensão da relação "ação/reação" existente entre pessoas e objetos.

A título de exemplo, Gell (1998) discorre sobre o papel ativo das decorações presentes nas embarcações utilizadas no ritual do Kula entre os habitantes das ilhas Trobriand, descrito pelo antropólogo Bronislaw Malinowski em "Os Argonautas do Pacífico Ocidental'. O autor compreende que tais desenhos não foram produzidos para serem contemplados, mas para serem eficientes, confundindo e encantando seus espectadores, de modo que estes acabam cedendo aos vizinhos seus objetos mais valiosos.

No Brasil, Lagrou (2007) em seus estudos sobre a arte Kaxinawa (Acre), dedica especial atenção ao aspecto fluido presente na (trans)formação de pessoas a partir da sua relação com os objetos. Estes aspectos, segundo a autora, estão intrinsecamente ligados à percepção e, consequentemente, aos sentidos, dentro do contexto da interação social. Assim:

\footnotetext{
${ }^{33}$ Sobre este fato, Gell publicou um livro, traduzido para o português sob o título "A rede de Vogel, armadilhas como obras de arte e obras de arte como armadilhas" onde faz uma reflexão sobre a exposição da artista, defendendo o valor artístico da citada rede de caça a partir de sua complexidade técnica.
} 
"Entender o processo da emergência do sentido como fenômeno histórico significa prestar atenção não somente nas formas e relações entre formas, mas também na relação temporal entre o aparecimento e o desaparecimento das formas, na relação entre forma e ausência de forma (Kingston, 2003), assim como entre fixidez e fluidez da forma" (LAGROU, 2007: 25).

Lagrou (2011) busca compreender a fluidez dos objetos como uma consequência da subjetividade dos sentidos e da dinâmica das relações sociais estabelecidas no tempo e no espaço. Assim, a autora busca uma definição interpretativa da arte ameríndia a partir de critérios de discurso, [ou seja] é arte aquilo que se produz em diálogo com a história da arte ou que se destaca de alguma maneira do fluxo cotidiano (LAGROU, 2011: 747-748).

Além da teoria de Gell, outros intelectuais pensaram uma antropologia da arte inovadora, porém com outro foco. Trata-se do debate norte-americano encabeçado por Sally Price (2000).

A autora propõe uma abordagem antropológica voltada para o estudo das práticas expositivas em museus e galerias de arte que integram aos seus acervos objetos etnográficos (e objetos arqueológicos também circulam neste meio) como objetos de arte, atribuindo-Ihes uma percepção estética supostamente universal. Segundo Lagrou (2007):

"defende a inclusão da arte não ocidental em exposições de arte, porém
segundo os critérios dos próprios produtores e receptores originais da
estética local em questão e com o mesmo tratamento que é
tradicionalmente dado aos artistas ocidentais, ou seja, com uma
circunstância da identificação do artista e dos estilos locais utilizados,
acompanhados de análise histórica dos mesmos" (LAGROU, 2007: 39-
40).

Este debate está centrado não na relação "sujeito/objeto", mas na relação "sujeito/sujeito", mais especificamente na relação "nós/outros", buscando romper com as relações assimétricas existentes entre a produção material ocidental e não-ocidental.

Tais teorias, num primeiro momento, podem parecer excludentes, contudo acredito que o fazer arqueológico consiste na construção do conhecimento a partir das relações entre pessoas e objetos ao longo do tempo.

A abordagem de Price (2000) se faz importante neste estudo por provocar reflexões acerca do papel de destaque atribuído aos vasilhames cerâmicos em exposições museológicas, mesmo que esses estejam, na maior parte dos casos, 
deslocados de seu contexto original. Isso acontece porque, como aponta Mano (2009), o caráter estético de tais objetos aguça nossos sentidos, provocando admiração, curiosidade, etc. e talvez este seja um dos motivos pelos quais se tornam objeto de estudo de tantos pesquisadores.

Já a abordagem de Gell (1998) provoca reflexões acerca da relação entre a cerâmica e seu contexto social original, a partir da qual levanto questões como "Por que foram produzidas?”, “Em que circunstâncias foram produzidas?", "Qual a relação existente entre os objetos e as artesãs?". Assim, considerando os contextos históricos, arqueológicos e etnológicos conhecidos, busco nesta dissertação compreender o papel ativo da cerâmica Tupi pintada diante de seus produtores e espectadores originais. 


\section{Capítulo 3: Pressupostos Metodológicos e Abordagens Analíticas}

No presente trabalho me proponho a realizar um ensaio interpretativo sobre os usos e funções da cerâmica Tupi pintada do interior paulista abrangendo desde seus aspectos tecnológicos e estilísticos até seus aspectos subjetivos, presentes sobretudo nos elementos decorativos.

Para tanto optei neste trabalho em analisar vasilhas que apresentam no mínimo $50 \%$ de integridade e/ou conjuntos de fragmentos que formam uma unidade de análise que permite sua reconstituição (e consequentemente a identificação de seu contorno).

Os dados alcançados em pesquisa foram interpretados a partir de duas abordagens: quantitativa, que se atém aos dados estatísticos do material estudado e se dedica ao estudo da frequência e distribuição de determinadas características (GOULART, 1982), e qualitativa, que permite o estabelecimento de tipos que determinam a tipologia ao levar-se em consideração as características de confecção, acabamento, forma, entre outras, que possam ser detectadas e cada um dos vestígios coletado (RODRIGUES, 2001: 06).

Vale a pena ressaltar que grande parte dos indivíduos alvo de estudo são provenientes de coletas aleatórias ou são resultados de pesquisas sistemáticas, porém contam com pouca ou nenhuma documentação primária (relatórios, fichas de análise, fotografias, etc.), muitos deles sequer passaram por um processo de higienização e/ou curadoria arqueológica. Logo, muitas vasilhas não receberam número de registro ou de tombo em suas instituições de guarda.

Diante deste cenário, com 0 intuito de facilitar a organização e sistematização dos meus dados, optei por atribuir um número de análise para cada unidade. Este número é formado por um código alfanumérico composto pela sigla da instituição ${ }^{34}$ de guarda seguida por um número sequencial, por exemplo: no Museu Histórico Sorocabano (MHS) analisei 6 vasilhas, logo, o número de análise para cada uma delas segue o padrão: MHS-01, MHS-02, MHS-03...

\footnotetext{
${ }^{34}$ As siglas de cada instituição de guarda estão descritas na Lista de Siglas no início deste volume. Vale ressaltar que, quando a peça apresentava algum tipo de numeração, este foi registrado no campo "Número da Peça" presente na ficha de análise.
} 
Tendo apresentado delimitado os critérios para seleção de um conjunto amostral, passo agora para os métodos e abordagens analíticas que permearam todo o processo de construção deste trabalho.

\subsection{Métodos de análise}

Para este trabalho, optei por realizar análises sob diferentes perspectivas: tecnológica, estilística e iconográfica, sendo a primeira aplicada ao total da amostra (53 vasilhas) a partir de uma abordagem quantitativa e qualitativa, onde busco interpretar os aspectos da produção oleira. Para as demais perspectivas (estilística e iconográfica) optei por trabalhar apenas com as vasilhas que apresentassem motivos gráficos bem preservados, formando o seguinte universo amostral:

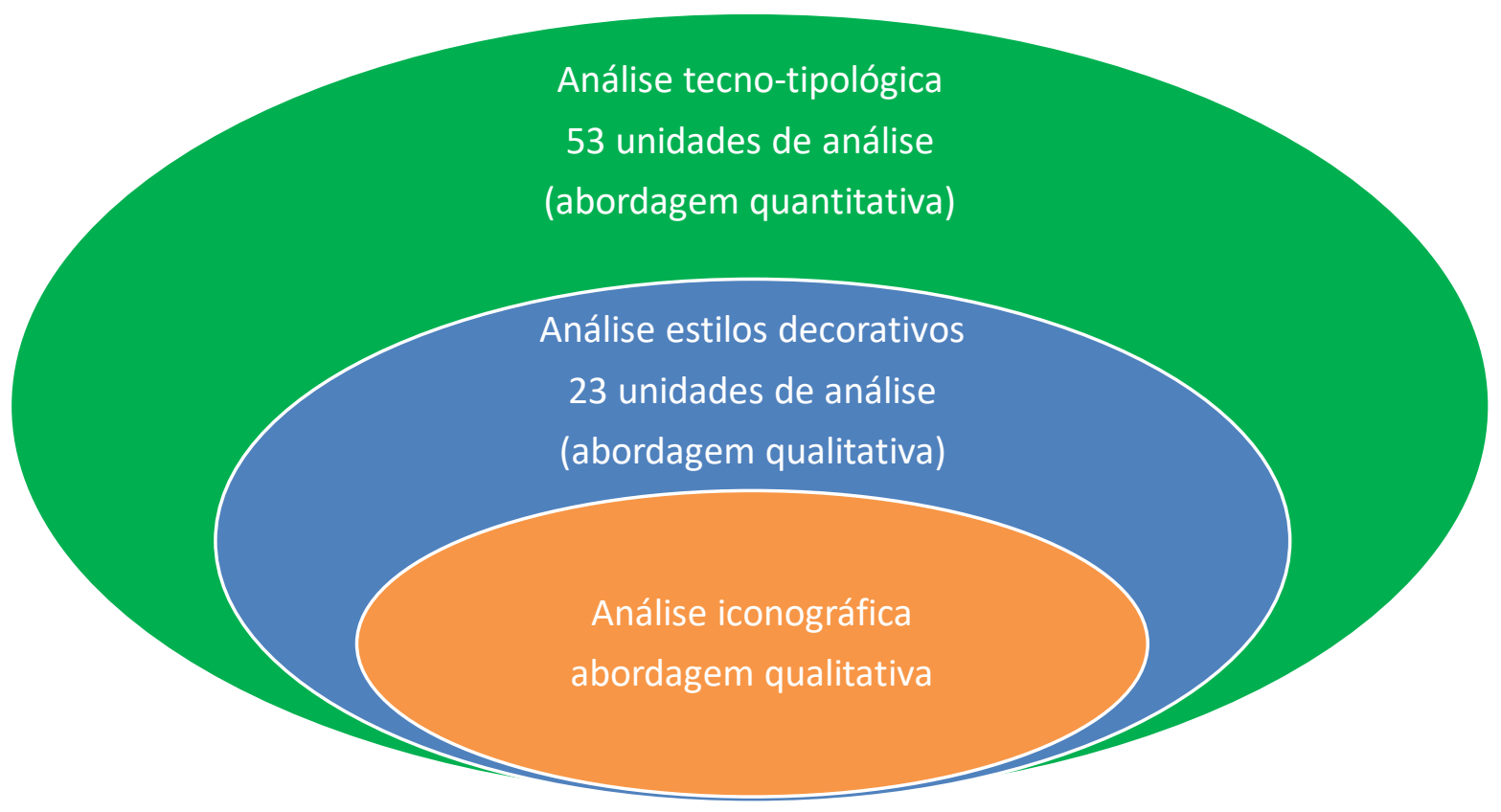

Figura 8: Relação quantitativa de indivíduos analisados em cada nível de análise

Para a perspectiva tecnológica elaborei uma ficha de análise ${ }^{35}$ (Anexo 1) contendo 27 atributos, agrupados em três categorias: relativo à produção, relativo à forma e relativo à pintura/decoração.

\footnotetext{
35 A ficha de análise foi elaborada junto com um roteiro de orientações (Anexo 2), no qual constam detalhadamente as informações e classificações de cada atributo.
} 
No que compete a primeira categoria, me apoiei no conceito de cadeia operatória, já apresentado no Capítulo 2, para elencar atributos que fizessem referência a todas as etapas do processo produtivo da cerâmica, desde o preparo da pasta até o acabamento final (decorativo).

Outro conceito importante que permeia toda a análise e abrange as três categorias supracitadas é o estilo tecnológico, uma vez que a produção oleira é resultado da ação de indivíduos inseridos em um determinado contextos social/histórico e aprendem o ofício passado a partir de narrativas e gestos, de geração para geração.

Neste campo meus principais referenciais metodológicos são àqueles que se dedicaram ao estudo da cerâmica Guarani, sobretudo La Salvia \& Brochado (1989), que realizaram um extenso levantamento de vasilhas no sul do país e se dedicaram exaustivamente aos estudos tecnológicos e formais das vasilhas, a partir dos quais levantaram um leque de possibilidades funcionais, cruzando fontes de diversas naturezas (antropológica, linguística, histórica, arqueológica, etc.). Também foram importantes manuais internacionais de análise cerâmica, com àqueles produzidos por Rice (1987), Rye (1981), Shepard (1971) e Orthon et al. (1997).

Neste trabalho, dedico atenção especial aos grafismos que estampam as superfícies cerâmicas, os quais foram descritos e agrupados por semelhança, considerando os fatores: composição do padrão gráfico ${ }^{36}$ no campo primário, orientação das repetições deste padrão (se houver), cores utilizadas, composição do padrão gráfico no campo secundário (se houver).

Algumas obras foram referência para análise sistemática dos padrões decorativos, como a síntese publicada por Marois et al.(1994) e a dissertação de Oliveira (2008) que se dedica não apenas à descrição dos traços, mas também às cores utilizadas para a composição da decoração.

É importante ressaltar que por se tratar de um tema pouco debatido no cenário arqueológico, os estudos dos padrões decorativos em cerâmica são sempre relativos, não sendo raro que pesquisadores(as) se deparem com

\footnotetext{
${ }^{36}$ Entendo por padrão gráfico uma composição de elementos que se combinam para formar o motivo gráfico presente nos campos primários e/ou secundários.
} 
múltiplos termos regionais que abordem os mesmos conceitos e objetos. Neste sentido, são importantes trabalhos que se dediquem a sínteses e unificações terminológicas que permitam estudos comparativos em níveis regionais e/ou nacionais.

Por fim, proponho um diálogo com a antropologia da arte e a semiótica, na tentativa de compreender as representações gráficas como partes de um sistema de comunicação visual, no qual as vasilhas ocupam, assim como os demais membros do grupo, o papel de agentes sociais. Neste contexto, busquei realizar uma análise qualitativa com o foco em alguns motivos que formam unidades figurativas como "cruz", "seta", "representações humanas" entre outros, entendendo-os como signos gráficos, dotados de significado para determinado grupo social.

Para tanto, dialogo com estudos etnológicos que se concentraram na interpretação da arte gráfica de populações indígenas atuais, em estudos etnográficos que abordem a arte indígena (sobretudo pintura corporal) de populações atuais, bem como em relatos de viajantes que mantiveram contato com populações indígenas nos primeiros três séculos de contato. Também são relevantes narrativas míticas coletadas por pesquisadores nas últimas décadas, mostrando elementos subjetivos da cultura.

\subsection{Métodos de registro pictográficos}

Entre os estudos que se dedicam à arte gráfica indígena, sobretudo àquelas de contextos arqueológicos, é comum o registro pictográfico dos grafismos por fotografias e/ou desenhos que reproduzam os motivos. No entanto, poucos são os trabalhos que descrevem o(s) método(s) de registro utilizados.

Posso dizer que há uma quantidade significativa de métodos de registros pictográficos além da fotografia, cabendo a cada pesquisador(a) a escolha do método que melhor se adequa ao material e condições de pesquisa.

Segundo Rodrigo Montero et al (2008):

"No que se refere à metodologia de representação gráfica de vasilhas pintadas ou dos motivos estéticos nelas contidos, a bibliografia existente no Brasil é pouco extensa, limitando-se a breves referências em 
trabalhos cujos objetivos discutem questões de natureza variada" (Ibid. p. 26).

Deste modo, os autores apresentam algumas possibilidades de registro e em qual (quais) situação(ões) seriam mais adequados, entre eles: reprodução dos grafismos a partir do desenvolvimento da superfície (Decalque), reprodução dos por meio da representação gráfica de projeções cilíndricas ou ortogonais, sistema de representação cônico ou de projeção oblíqua.

Entre os métodos apresentados pelos autores, o mais comum é a reprodução por decalques, e foi este o método que escolhi para reproduzir os padrões gráficos das vasilhas que analisei, considerando as dimensões e formas dos objetos e recursos disponíveis para pesquisa.

O decalque resulta na reprodução da superfície aberta do objeto decalcado (p. 28) e consiste em revestir a superfície do objeto com plástico transparente flexível o suficiente para se moldar sobre a peça e rígido o suficiente para evitar irregularidades que podem afetar o resultado final.

Preciso ressaltar que, de maneira geral, as vasilhas que analisei apresentavam grafismos em duas grandes categorias: internos e externos, muitos deles um tanto gasto. Diante disto, optei por selecionar o ponto da vasilha onde os motivos estavam melhor preservados e neste ponto realizei o decalque, partindo do pressuposto, considerando a bibliografia arqueológica sobre 0 assunto (OLIVEIRA, 2008; MORAES, 2007; PROUS, 2005, 2009, 2011; LA SALVIA \& BROCHADO, 1989), de que a pintura/decoração é composta por um conjunto de elementos que constituem um padrão gráfico que se repete ordenadamente na vasilha. 


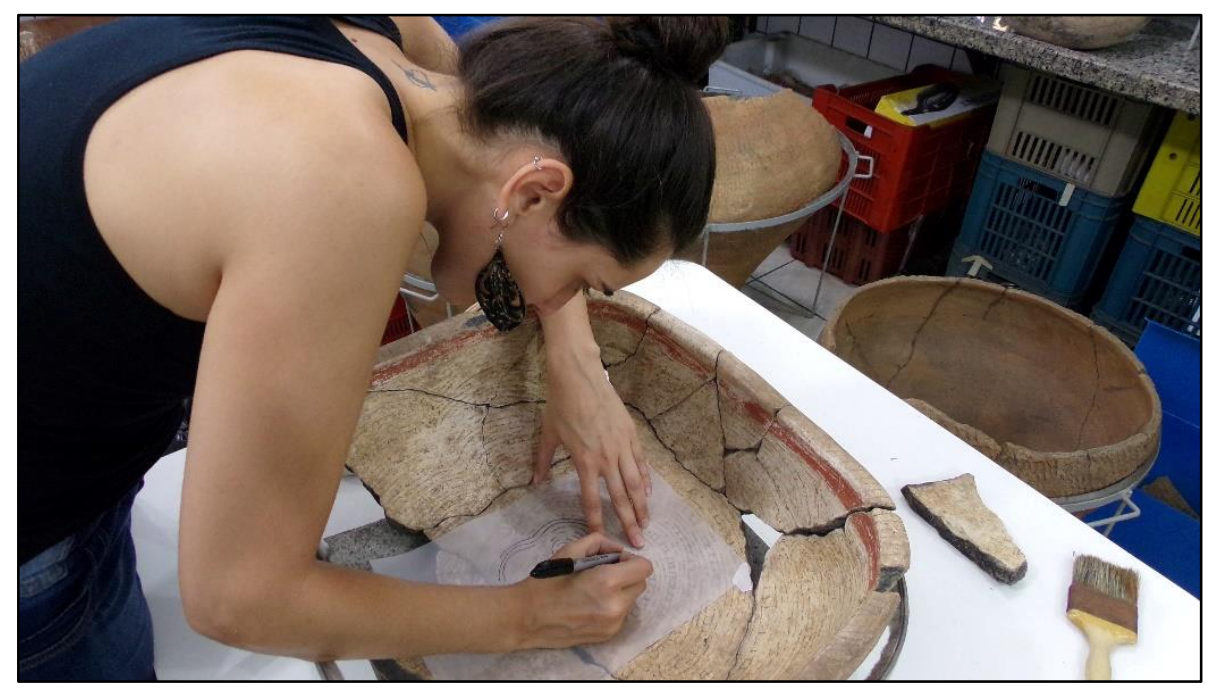

Figura 9: Decalque de vasilha com pintura interna

Os decalques foram feitos em plásticos ou papel vegetal em alguns casos. Para os desenhos utilizei canetas permanentes com espessura 1.0 para reproduzir os motivos confeccionados com pincel fino, adotando a cores vermelha (para representar cores escuras) e preta (para representar as cores muito escuras $^{37}$ ), e 2.0 para reproduzir os motivos confeccionados em pincel grosso e para as faixas (bandas) que delimitam os campos gráficos.

O segundo passo no que se refere ao registro da pintura/decoração foi escanear os decalques e vetorizar as imagens utilizando o programa Vector Magic, com ele é possível transformar a imagem em um vetor, o que possibilita alterar seu tamanho sem prejudicar a resolução da mesma.

Vale ressaltar que os decalques foram destinados a vasilhas cujos motivos estavam em bom estado de conservação, permitindo a identificação de um padrão gráfico. Porém, todas as vasilhas foram devidamente fotografadas, a fim de registrar detalhes da pintura e seu contorno.

${ }^{37}$ No item 4.1 da dissertação apresentarei melhor a questão das cores para as populações Tupi. 


\section{Capítulo 4: A análise das Coleções e os Resultados Obtidos}

Para esta pesquisa elenquei um conjunto de vasilhas de coleções arqueológicas salvaguardadas por 10 museus e/ou instituições de pesquisa do interior paulista, abrangendo um total de 53 indivíduos (unidades de análise), conforme indico na Tabela 1. As coleções estudadas se concentram principalmente nas porções leste e oeste do estado, conforme indicado na Prancha 01.

\begin{tabular}{|c|c|c|c|c|}
\hline & Instituição & Município & $\begin{array}{c}\text { Unidades de } \\
\text { Análise }\end{array}$ & $\begin{array}{l}\text { Percentual da } \\
\text { amostra }\end{array}$ \\
\hline 1 & Museu Histórico Sorocabano & Sorocaba & 6 & $11 \%$ \\
\hline 2 & Museu da Cidade de Salto & Salto & 1 & $2 \%$ \\
\hline 3 & Museu Santuário Nacional de Aparecida & Aparecida & 4 & $7 \%$ \\
\hline 4 & $\begin{array}{l}\text { Centro de Museologia, Antropologia e } \\
\text { Arqueologia }\end{array}$ & $\begin{array}{l}\text { Presidente } \\
\text { Prudente }\end{array}$ & 14 & $26 \%$ \\
\hline 5 & Museu de Arqueologia Regional & $\begin{array}{l}\text { Presidente } \\
\text { Prudente }\end{array}$ & 6 & $11 \%$ \\
\hline 6 & Museu de Arqueologia de lepê & lepê & 3 & $6 \%$ \\
\hline 7 & Centro Regional de Arqueologia Ambiental & Piraju & 4 & $8 \%$ \\
\hline 8 & Fundação Cultural Jacareí & Jacareí & 12 & $23 \%$ \\
\hline 9 & Museu Municipal Elizabeth Aytai & Monte Mor & 2 & $4 \%$ \\
\hline \multirow[t]{2}{*}{10} & Museu Municipal de Mogi Guaçu & Mogi Guaçu & 1 & $2 \%$ \\
\hline & Total & & 53 & $100 \%$ \\
\hline
\end{tabular}

\section{Tabela 1: Relação de indivíduos analisados por instituição}

Optei por organizar o capítulo em duas partes: na primeira trago, sob abordagem quantitativa e qualitativa, informações que compreendem os modos de fazer cerâmica, tendo como eixo norteador os conceitos de cadeia operatória e estilo tecnológico, já apresentados no Capítulo 2; na segunda parte me concentrarei nos estilos decorativos apresentando uma breve descrição e espacialização dos padrões identificados os quais serão interpretados a luz da teoria antropológica da arte na tentativa de compreender o papel agentivo dos objetos em seus contextos originais. 
Parte 1

A relação da artesã com a vasilha tem início nos primeiros momentos da produção em que a ceramista se depara com inúmeras possibilidades tecnológicas e realiza suas escolhas considerando fatores de ordem prática e social. Estas escolhas estão sob influência das condições apresentadas pelo meio ambiente, mas também carregam traços de identidade individual e coletiva, como apresentarei adiante.

Trago na Figura 10 um fluxograma com as etapas que compõem a cadeia operatória das vasilhas pintadas.

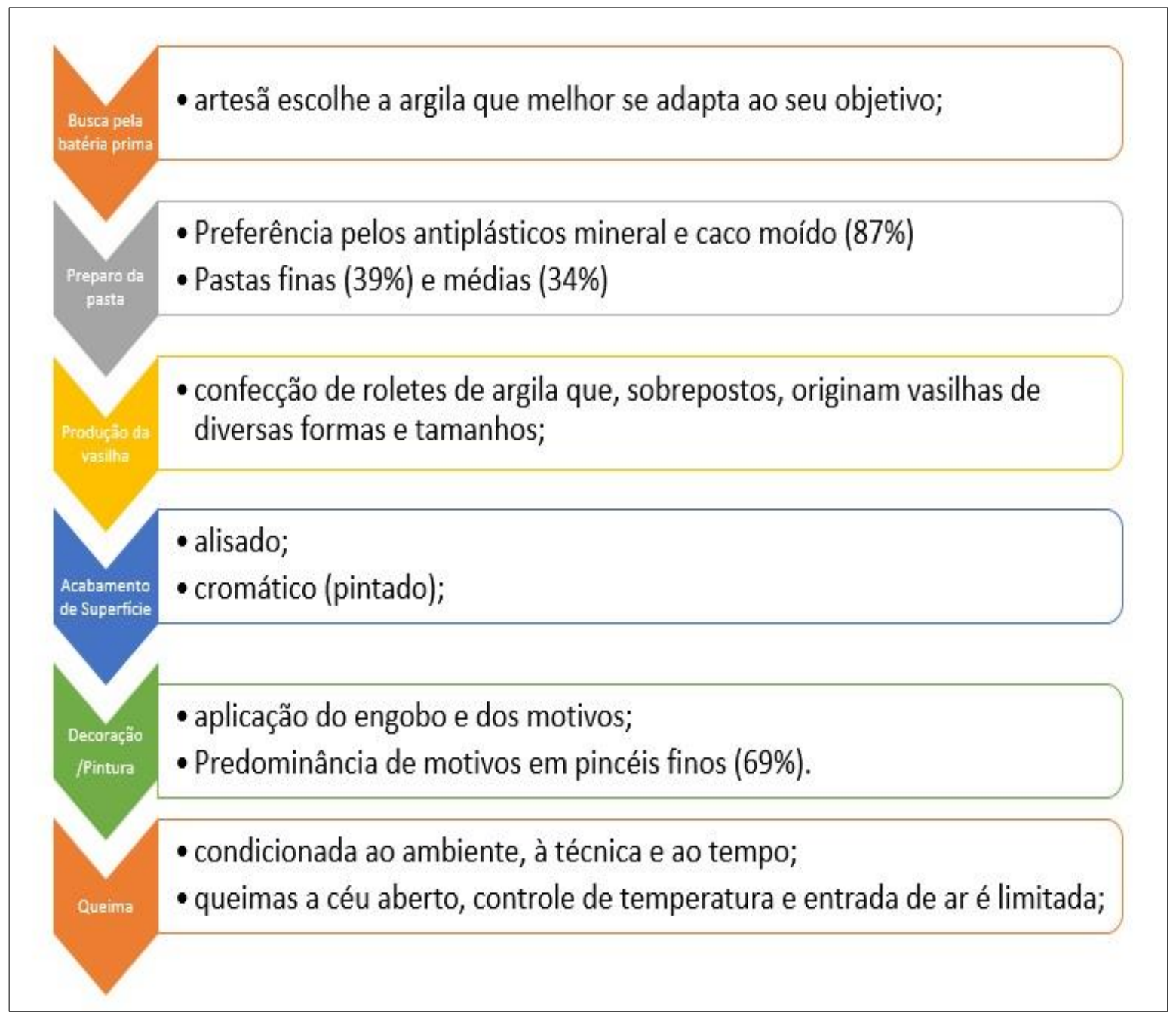

Figura 10: Fluxograma da cadeia operatória da cerâmica Tupi baseada em La Salvia e Brochado (1989)

No que compete à técnica de manufatura, La Salvia e Brochado (1989) afirmam que o acordelado é a mais comum entre as vasilhas identificadas pelos autores como "Guarani”. Esta técnica foi definida como uso de cordéis de argila que, sobrepostos, dão a forma pretendida (LA SALVIA \& BROCHADO, 1989: 11). 


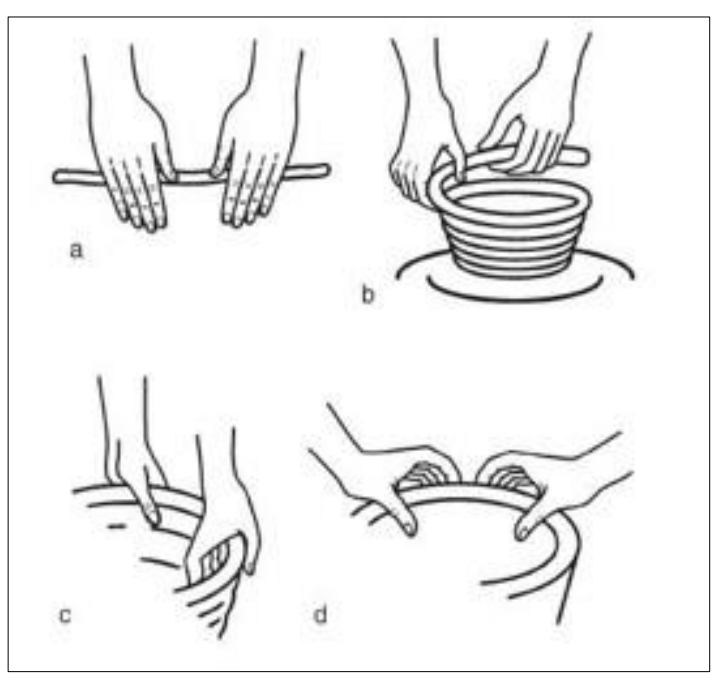

Figura 11: Etapas do processo de montagem a partir da técnica do acordelado (SCATAMACHIA, 2004: 292)

Pude identificar o uso do acordelado em todas as vasilhas que analisei. A técnica é evidenciada principalmente em fragmentos cujas fraturas ocorreram justamente na junção entre um rolete e outro, mas também são perceptíveis na textura da superfície.

Para confeccionar uma vasilha, a ceramista precisa de matéria-prima adequada, ou seja, deve selecionar uma argila à sua exigência que se molde às suas necessidades, que se adapte ao seu desejo de ceramista, sem maiores alterações (LA SALVIA E BROCHADO, 1989: 11). Porém, algumas vezes a argila in natura não é o suficiente para que a ceramista alcance a forma desejada. Por isso, é comum que arqueólogos(as) identifiquem nos artefatos cerâmicos a presença de elementos minerais (areia, caco de cerâmica moída, também conhecida como chamote, quartzo, óxido de ferro, etc), vegetais (fibra vegetal, também conhecida como cariapé) e/ou animais (conchas, ossos ou dentes triturados), denominados na bibliografia arqueológica como antiplásticos (ou temperos).

Trata-se de elementos importantes no processo de confecção cerâmica, contudo, sua definição ainda gera debates. Se por um lado alguns pesquisadores(as) definem antiplásticos como elementos que reduzem a plasticidade da argila, influenciando também no processo de secagem e queima, diminuindo o risco de rachaduras, podendo ser resultado de ação antrópica ou não, por outro lado, alguns pesquisadores consideram antiplásticos apenas aqueles elementos adicionados no processo de confecção da vasilha. 
Neste trabalho, dialogo com a primeira definição, considerando todos aqueles elementos que reduzem a plasticidade da pasta, seja ele natural ou não. Esta abordagem é defendida por Shepard (1971), Rye (1981) e, no Brasil, por La Salvia e Brochado (1989), que apontam para dificuldade de identificar os elementos minerais que são adicionados à pasta por escolha da artesã, lembrando que $A$ determinação de antiplásticos existentes ou adicionados só será possível quando as amostras de argila forem comparadas com as já queimadas, de um mesmo sítio, contemporâneo e em uma mesma posição estratigráfica (LA SALVIA \& BROCHADO, 1989: 12). Apenas um elemento mineral foge desta regra: o caco moído, que consiste no aproveitamento de vasilhas cerâmicas que se quebram durante a queima ou uso e tem seus fragmentos triturados e acrescentados à argila.

A combinação de antiplásticos é muito comum e, segundo Moraes a variabilidade dos antiplásticos presentes e a associação frequente de mais de um tipo de antiplástico na mesma peça revelam a atenção do grupo ceramista em controlar a resistência e permeabilidade da argila (MORAES, 2006: 8).

Nas vasilhas que analisei pude identificar a ocorrência de três elementos: mineral, provavelmente grãos de quartzo provenientes de areia, caco moído e carvão, que na maioria dos casos se apresentam de forma combinada, sendo a combinação mineral + caco moído a mais frequente, presente em $87 \%$ das amostras, como fica evidente no Gráfico 1.

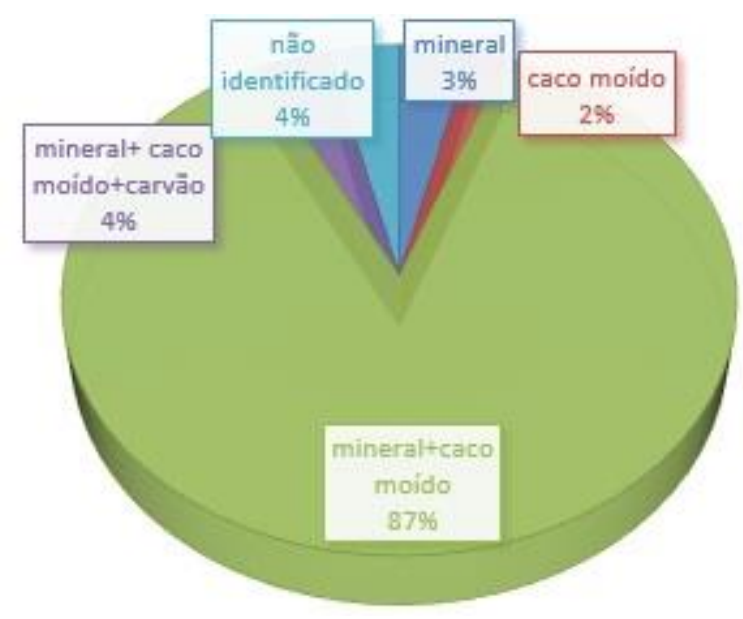

Gráfico 1: Tipos de antiplástico

Para alguns pesquisadores (MEGGERS \& EVANS, 1970), além de trazer informações acerca dos processos produtivos, o estudo dos antiplásticos pode 
revelar traços culturais, sendo elencado pelos pronapianos como importante demarcador para identificação de tradições e fases arqueológicas

La Salvia e Brochado (1989), embora reconheçam a importância do estudo minucioso da pasta e dos tipos de antiplásticos e temperos utilizados na produção cerâmica, tecem uma crítica à utilização deste atributo como definidor de tradições arqueológicas, uma vez que tanto a escolha da argila quanto a escolha dos elementos adicionados são guiadas por uma série de fatores de ordem natural e social, nas palavras dos autores:

"Todo artefato cerâmico parte de uma argila transformada em pasta e os
elementos intervenientes são tantos e a interdependência e o inter-
relacionamento são tais, que não podemos aceitar a sua presença como
elemento decisório de um contexto cultural. Não é um simples fato de
pertencer a uma cultura e habitar um conjunto ecologicamente classificado
que determinará uma produção igual" (LA SALVIA \& BROCHADO, 1989: 12).

Assim, reconheço a relação complexa que permeia o processo produtivo da cerâmica. No entanto, é evidente a preferência da combinação de caco moído e mineral como antiplásticos pelas ceramistas Tupi, o que vem sendo, desde as pesquisas desenvolvidas pelo PRONAPA, um traço marcante na produção oleira destes grupos.

Os antiplásticos aparecem nas vasilhas em diferentes graus de concentração e dimensões, indicando a intenção da ceramista em adequar a argila à sua maneira, dominando suas características naturais, tornando-a mais ou menos plástica de acordo com suas necessidades. Existe uma gama muito grande de pasta e inter-relação entre argila e antiplástico, mas a fixação de um critério define melhor, como também facilita o entendimento descritivo por parte do arqueólogo [a] (LA SALVIA \& BROCHADO, 1989: 17). La salvia \& Brochado propõem uma análise da pasta a partir do percentual de antiplásticos, definindo a partir daí cinco categorias: dura, seca, medianamente seca, plástica e muito plástica, nas quais o grau de plasticidade vai diminuindo de acordo com a quantidade de antiplásticos utilizados. Com base na proposta dos autores, elenquei três possibilidades de pasta ${ }^{38}$ : fina (menos antiplástico, mais argila),

\footnotetext{
${ }^{38} \mathrm{O}$ detalhamento percentual de argila e antiplástico não foi possível neste estudo, uma vez que o único equipamento utilizado em análise foi uma lupa portátil de aumento 40x, não trazendo informações precisas. Por isso, optei por simplificar a proposta dos autores, identificando apenas três tipos de pasta.
} 
média (relação antiplástico/argila equilibrada) e grossa (mais antiplástico, menos $\operatorname{argila}^{39}$.

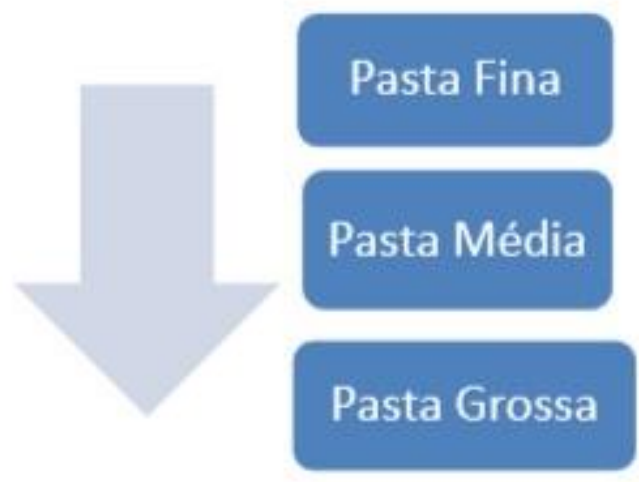

Figura 12: Grau de plasticidade da pasta

Para as vasilhas em epígrafe identifiquei a predominância de pastas finas e médias, conforme indicado no Gráfico 2, o que atesta a preferência das ceramistas em trabalhar com pastas mais plásticas e maleáveis que permitam seu manuseio sem que o rolete se rompa no momento da confecção da vasilha.

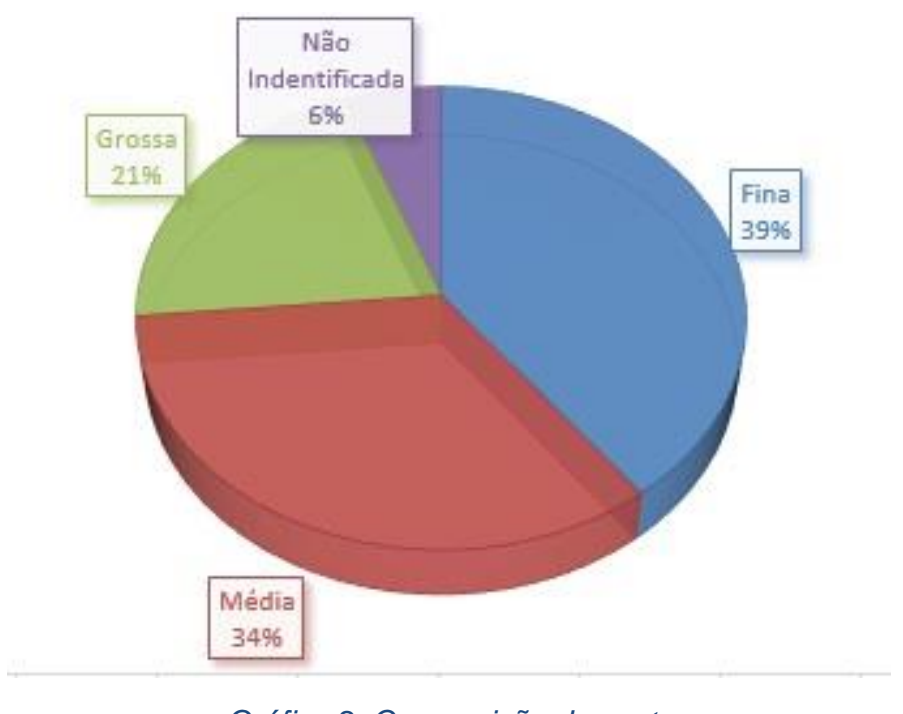

Gráfico 2: Composição da pasta

Tendo finalizado a etapa de construção e alcançando a forma desejada, a artesã se dedica ao acabamento de superfície do recipiente na tentativa de eliminar rugosidades e/ou corrigir possíveis imperfeições. Este tratamento pode ser realizado de diversas maneiras.

\footnotetext{
${ }^{39}$ Para La Salvia e Brochado (1989) em uma mesma vasilha é possível identificar diversas pastas utilizadas em diferentes etapas do processo produtivo: uma para a confecção dos roletes utilizados na construção da vasilha, outra, muitas vezes com menor quantidade de antiplásticos, para o acabamento de superfície, e uma terceira pasta, por sua vez bem fina, para a "decoração" [engobo, por exemplo]. Neste trabalho, tive como foco a análise da pasta utilizada no processo de confecção da vasilha.
} 
La Salvia e Brochado (1989) apontam para cinco tipos de acabamento de frequentemente identificados em vasilhas Tupi, são eles: alisamento, que pode variar entre alisamento bom ou ruim, este último caracterizado pelas marcas da ferramenta utilizada pela artesã no momento do alisamento. Este tipo de tratamento é o mais frequente, pois mesmo vasilhas ornamentadas (seja com pinturas ou texturas) costumam apresentar partes alisadas; barbotina, que pode ser caracterizada como um revestimento superficial de argila mais refinada, aplicado à cerâmica antes da queima (LA SALVIA \& BROCHADO, 1989: 17); banho, caracterizado pelos autores como revestimento superficial delgado, proveniente de um caldo ou nata de argila em suspensão na água, aplicado à superfície cerâmica antes da queima (LA SALVIA \& BROCHADO, 1989: 18); acabamento cromático, este tipo de tratamento se refere aos "engobos", um banho de argila de espessura delgada e com algum tipo de pigmentação, frequentemente branco ou vermelho, o primeiro frequentemente aparece associado às pinturas, servindo de pano de fundo para destacar os motivos desenhados; acabamento plástico, caracterizado como aquele que provoca alterações tridimensionais na superfície da parede (LA SALVIA \& BROCHADO, 1989).

Os autores classificam os acabamentos em duas categorias: de cunho prático, que tem como finalidade aprimorar construção da vasilha com a fixação dos cordéis de argila e, consequentemente solidificando as paredes; e de cunho artístico, aquele que tem como objetivo decorar a vasilha.

Neste trabalho entendo que os tratamentos de cunho artístico/decorativo também podem ser entendidos como práticos, pois assumem funções técnicas ou simbólicas. Os próprios autores apontam para a dupla função dos tratamentos plásticos ${ }^{40}$, como o corrugado por exemplo, uma vez que estes podem estar associados ao ato da ceramista no momento de unir os roletes. $\mathrm{O}$ tratamento de superfície pintado, por outro lado, assume papel importante na dinâmica social dos indivíduos e/ou grupos.

\footnotetext{
${ }^{40}$ Além disso, diversos autores (MONTOYA, 1876; LA SALVIA \& BROCHADO, 1989; NOELLI, 1993; BROCHADO \& MONTICELLI, 1994) apontam para o uso recorrente das cerâmicas corrugadas nas atividades de cocção, podendo estar associado a manutenção e distribuição de calor ou ainda acelerar o aquecimento. No entanto, em um estudo de experimentação realizado por Cerezer (2011), o autor aponta que não foi possível identificar diferenças significativas neste sentido para cerâmicas alisadas e corrugadas.
} 
É comum que os acabamentos apareçam de forma combinada. No caso das vasilhas que analisei, a combinação mais comum é pintura e alisamento. No entanto, três vasilhas, todas da mesma região, sendo um proveniente do sítio arqueológico Tuiuiu, localizado no município de Rosana, e dois provenientes do sítio Mandaguari, localizado no município de Presidente Prudente, apresentaram a combinação de acabamentos plástico e pintado na superfície externa (Figura 13).

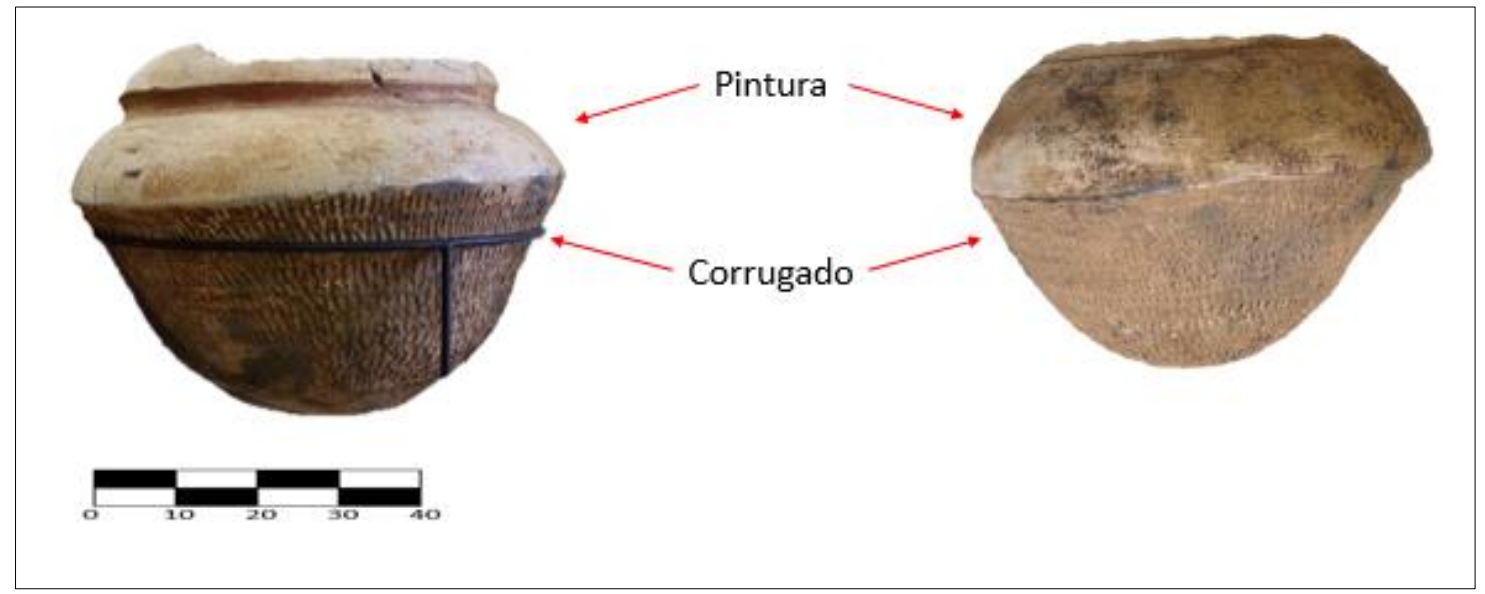

Figura 13: Vasilhas com acabamento cromático (pintura) na parte superior ao bojo e acabamento plástico (corrugado) na parte inferior ao bojo

A presença de dois tipos de acabamento considerados artísticos foi definida por La Salvia e Brochado como decoração mista. Segundo os autores, estes casos são pouco comuns, não havendo estudos detalhados a respeito. Ainda hoje não há estudos que se debrucem sobre este tema. No entanto, alguns questionamentos podem ser levantados a partir destas peças: segundo consta em bibliografias de referência sobre usos e funções da cerâmica entre grupos de matriz cultural Tupi (LA SALVIA \& BROCHADO, 1989; NOELLI, 1993; MONTOYA, 1639) é consenso a recorrência da utilização de vasilhas com acabamento plástico, sobretudo corrugado, no preparo de alimentos por fervura. Por outro lado, vasilhas ornamentadas com pinturas seriam destinadas ao armazenamento de líquidos, sobretudo bebidas fermentadas e não podem ser utilizadas em contato direto com o fogo. Temos, portanto, que repensar os usos e funções das vasilhas e de seus acabamentos.

Também pude identificar a combinação de pintura com pintura. Vale ressaltar que, no caso de vasilhas abertas a pintura é aplicada na face interna e o alisamento na face externa. $O$ inverso acontece com vasilhas restritas, onde a 
pintura se encontra na face externa e o alisamento na face interna. No entanto, ainda que de forma pontual, pude identificar vasilhas com acabamento cromático em ambas as faces. No caso de vasilhas a face externa recebeu engobo vermelho (Figura 14), já nas vasilhas restritas, apresentaram marcas de dedos na face interna, próximo à borda (Figura 15).

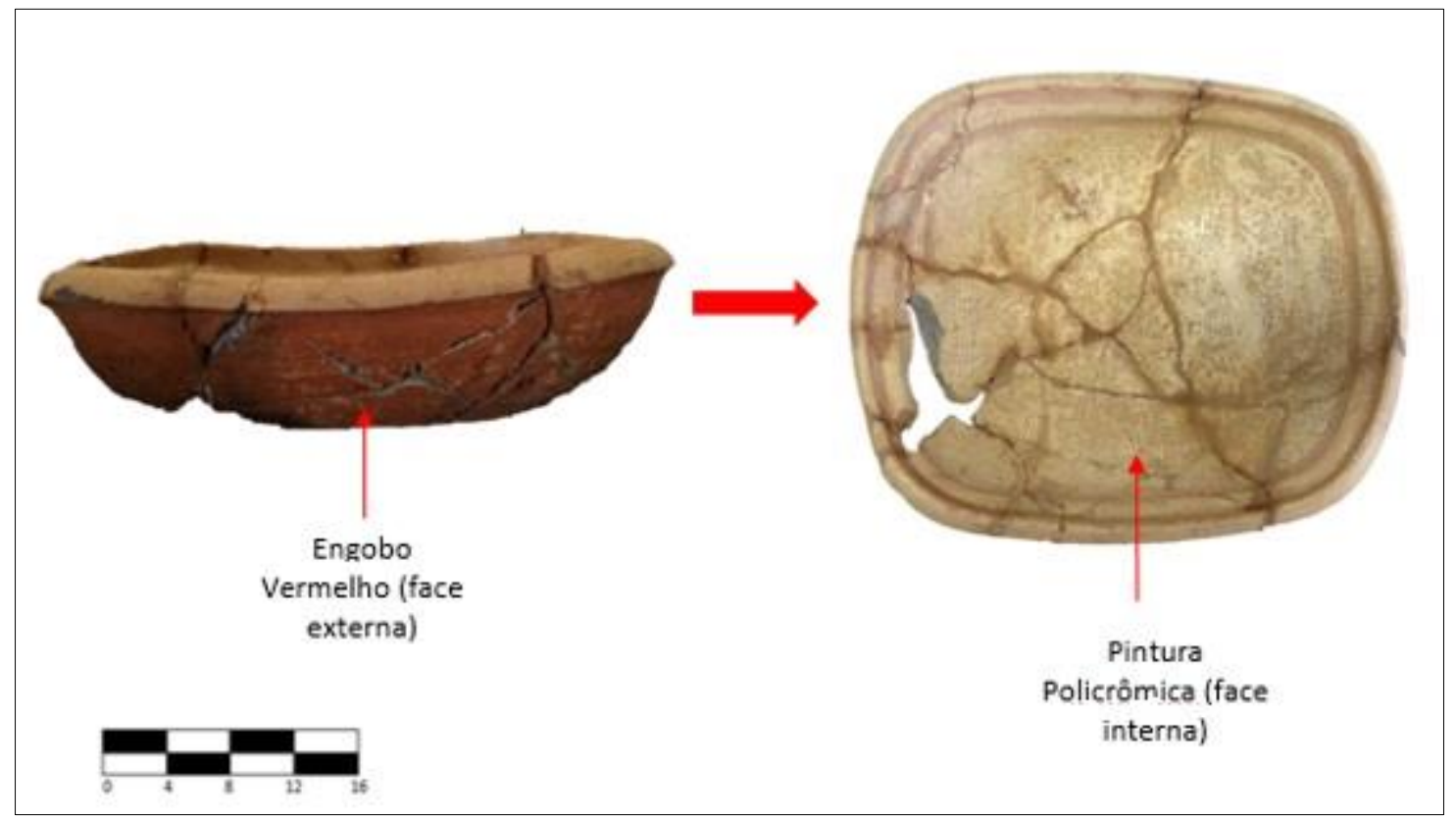

Figura 14: Vasilha com engobo vermelho na face externa e pintura na face interna (MHS-03)

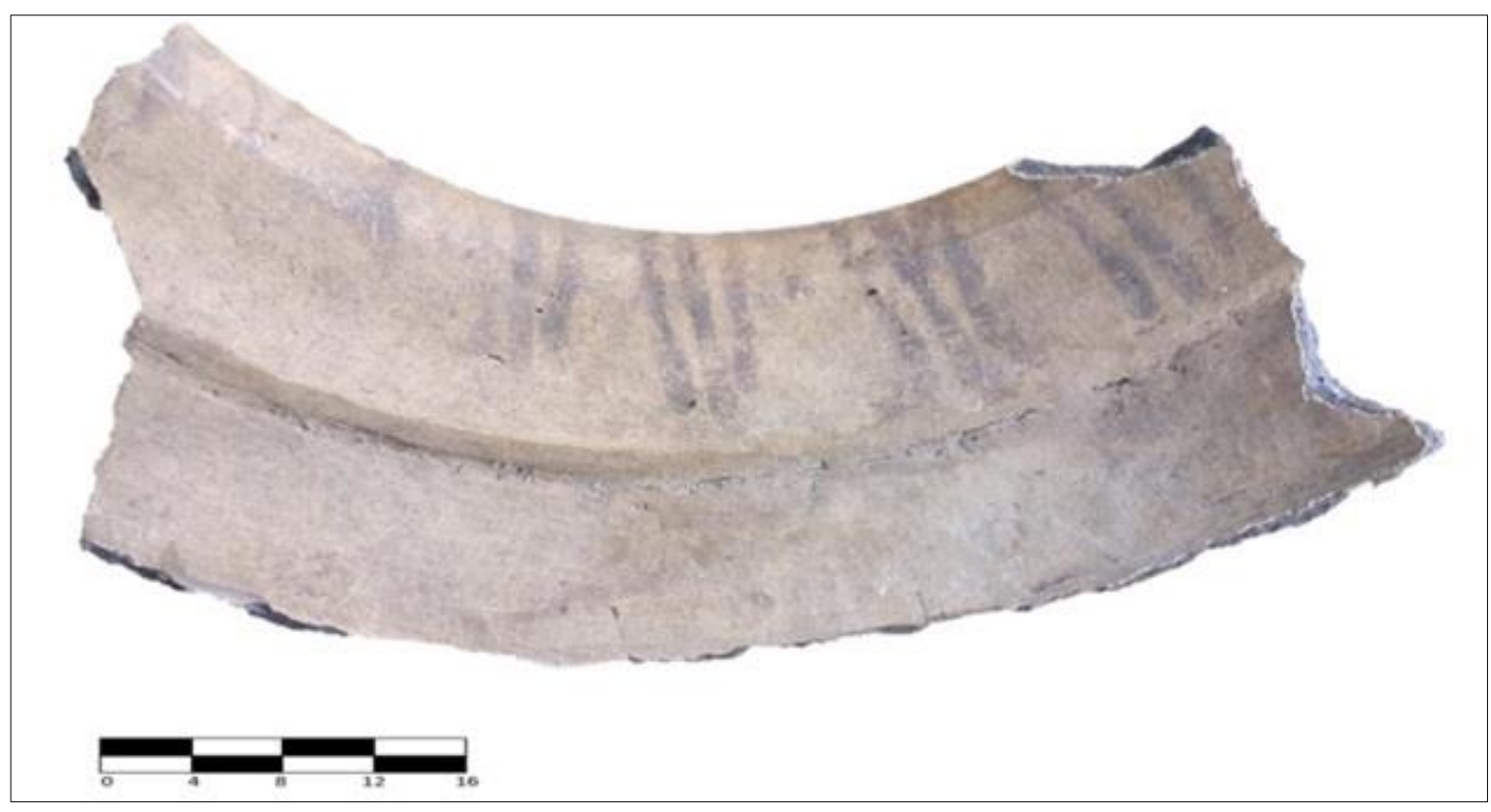

Figura 15: Vasilha com marcas de dedos na face interna próximo ao lábio

As pinturas seguem um padrão: o preparo da superfície com a aplicação do engobo branco e aplicação dos motivos, que costumam ser feitas com pincéis de variam em espessura, como fica evidente no Gráfico 3. 


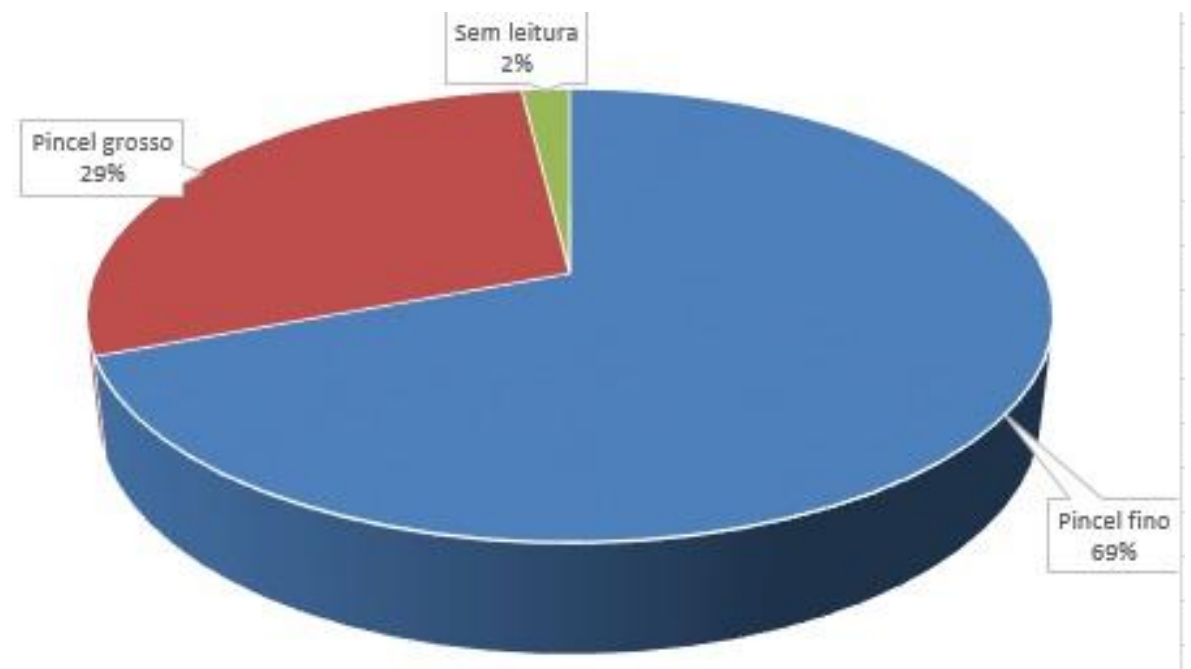

Gráfico 3: Ferramenta utilizada na aplicação dos grafismos

Identifiquei a predominância de grafismos aplicados com pincel fino, representando $69 \%$ da amostra. Estes são mais comuns em vasilhas abertas e eram utilizados para a confecção de linhas contínuas com menos de espessura de $1 \mathrm{~mm}$ e/ou linhas pontilhadas que tendem a formar motivos curvilíneos.

Em menor quantidade identifiquei o uso de pincel grosso, mais comum em vasilhas restritas, utilizados na confecção de linhas que variam de 1 a $3 \mathrm{~mm}$ de espessura e geralmente compõem motivos retilíneos.

O uso de pincéis por povos Tupi para a confecção de pinturas corporais e nas vasilhas cerâmicas, bem como em outros suportes, é apontado na bibliografia histórica por Léry.

"Para esse serviço [a aplicação de grafismos em vasilhas cerâmicas]
usam um certo licor branco [engobo] que logo endurece. Preparam
também tintas pardacentas com as quais pintam a pincel pequenos
enfeites, como ramagens, lavores eróticos etc., principalmente nas
vasilhas de barro em que se guarda a farinha" (LÉRY, [1578] 1961: 186-
187).

No entanto, o viajante não entra em detalhes a respeitos de como e a partir de quais materiais eram confeccionados. Alguns trabalhos de etnoarqueologia apontam para a utilização de elementos animais e/ou vegetais para sua confecção, que podem gerar traços finos e/ou grossos, de acordo com o desejo da ceramista.

Fabíola A. Silva (2001), ao acompanhar o processo de produção cerâmica das mulheres Assurini (povo indígena de matriz cultural Tupi), descreve: 
"Depois de resfriadas as vasilhas, as mulheres iniciam a pintura na superfície externa. Com um chumaço de algodão (amyniju) elas passam o pigmento amarelo sobre a superfície da vasilha, o que constitui no fundo da pintura.

Depois elas iniciam a pintura propriamente dita com pigmentos vermelho e preto. Para aplicá-los, elas usam três tipos de pincéis: pena de mutum (muturuaja) para os traços finos, raque de babaçu ou inajá (pina 'wype) e o talo de uma leguminosa (jupuywa) para os traços grossos" (SILVA, 2001: 71).

É possível perceber alguns pontos em comum entre a cerâmica arqueológica Tupi e a etnográfica apresentada pela autora no que se refere à composição da decoração, pois sambas são formadas por motivos nas cores preta e vermelha sobre um fundo mais claro.

A autora aponta ainda para uma última etapa no tratamento de superfície: a aplicação de uma resina sobre a pintura que, no caso da cerâmica etnográfica Assurini é feita a partir do jatobá (jutaika). No caso da cerâmica arqueológica, La Salvia e Brochado (1989) reconhecem que há narrativas apontando para a utilização de um verniz que fixa a pintura nas vasilhas e torna as cores mais vivas, no entanto, os autores não identificaram sua presença nas coleções analisadas no sul do Brasil.

Jácome (2006) em seu mestrado analisou uma série de fragmentos cerâmicos pintados associados ao elemento Tupi de Minas Gerais. A autora aplicou testes de solubilidade (entre outros) em um conjunto de amostras a fim de identificar elementos resinosos que atuassem na preservação dos motivos. $O$ teste deu positive para um número pequeno de amostras, porém não foi identificado a origem da resina, se animal ou vegetal. Além disso, a autora aponta para a associação duvidosa entre a amostra e seu contexto arqueológico.

Em minha pesquisa não realizei testes químicos que atestassem a utilização de verniz e/ou resinas, estas também não foram identificadas mesmo com o auxílio de lupa. No entanto, considerando a longevidade e o estado de preservação dos motivos identificados em algumas vasilhas, há de se considerar a utilização de elementos destinados a fixação e conservação dos mesmos.

Acredita-se que a aplicação das pinturas em vasilhas arqueológicas seja anterior à queima, pois a combustão auxiliaria na fixação dos pigmentos (BROCHADO, 1984). No entanto trabalhos de etnoarqueologia como o de Silva (2001) demonstram a aplicação da pintura após a queima, 
Sallum (2011) em seu trabalho experimental realizou testes com as duas possibilidades: aplicação de pintura antes da queima e depois da queima e concluiu que a aderência dos pigmentos é maior quando aplicados antes do processo de queima e que o engobo (a base da pintura) tende a descascar com maior facilidade quando aplicado após a cozedura da argila.

O processo de queima das vasilhas, executado logo após o acabamento de superfície e secagem, pode ser considerado uma etapa importante da produção oleira, pois é a partir dela que a argila é transformada em cerâmica por meio do aquecimento, que por sua vez, provoca transformações químicas na estrutura da argila, tornando-a mais resistente e impedindo que a vasilha se desfaça quando em contato com a água ou se rompa quando em contato com o fogo (CEREZER, 2011).

Segundo Cerezer (2011), as formas de cozer a cerâmica variam de acordo com a estrutura utilizada. No caso de povos indígenas, o mais comum era a realização de queimas em ambientes abertos, podendo acontecer em fogueiras ou covas. Nestes contextos, o resultado é a formação de uma atmosfera que chamamos oxidante por apresentar maior quantidade gás oxigênio (O2) e menor quantidade de gás carbônico (CO2). Vale ressaltar que, segundo o autor, nestes ambientes o controle de temperatura é dificultado, pois depende da quantidade de combustível disponível e das condições climáticas. O resultado deste processo é a presença de manchas escuras que podem ocorrer na superfície das vasilhas ou ainda a presença de núcleos e/ou faixas escuras perceptíveis nos planos de fratura de fragmentos cerâmicos. 


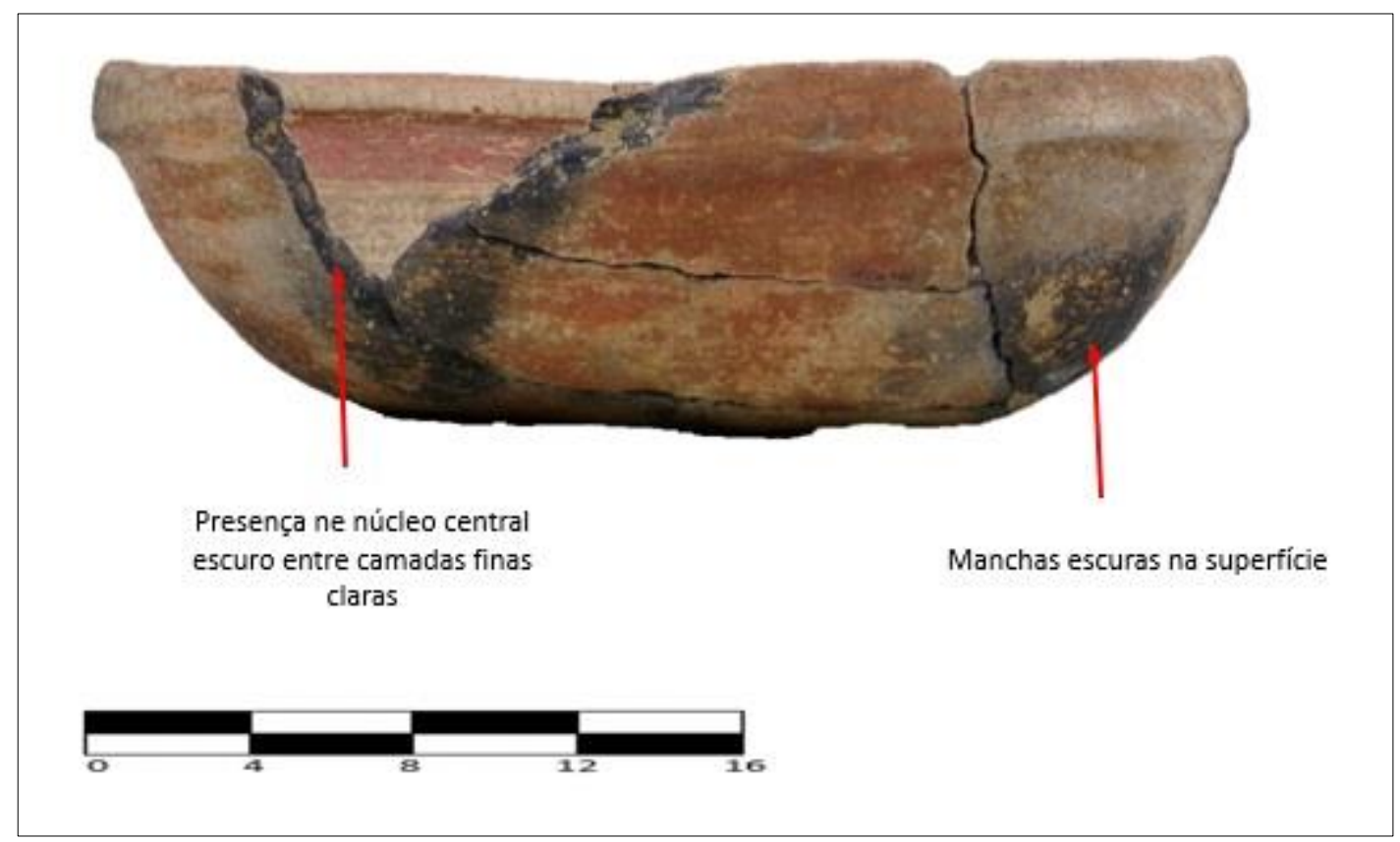

Figura 16: Vasilha (FCJ 03) com mancha escura na superfície externa e núcleo escuro no plano de fratura resultantes de queima em atmosferas oxidantes

Para identificar o método de queima e a estrutura de combustão adotada pelas ceramistas que produziram as vasilhas que estão em foco neste estudo, adotei a proposta de análise de Orton e Hugues (2013), que consiste na observação na coloração em cinco zonas de uma vasilha. A primeira delas é o núcleo, ou seja, a parte menos exposta à atmosfera de combustão. Segundo os autores, as vasilhas cujos núcleos são escuros, com cores que variam de preto a cinza escuro, provavelmente contém carbono derivado da queima incompleta de material orgânico presente na pasta, à medida em que os elementos orgânicos vão sendo oxidados, a pasta vai assumindo cores mais claras. A segunda zona observada seria as margens dos planos de fratura (definida pelos autores como aquela entre o núcleo e as superfícies). As margens podem seguir o mesmo padrão de cores e tonalidades do núcleo ou apresentar cores mais claras. No primeiro caso, podemos entender que as estruturas de combustão permitiram a queima completa da argila (quando claras), ficando em condições adequadas de calor e/ou em tempo suficiente para que a porção central seja oxidada na mesma medida que as extremidades. Ou ainda, pode ocorrer de o plano de fratura apresentar uma única camada escura. Neste caso, entendemos que a quantidade de calor e o tempo de combustão não foram suficientes para que os elementos orgânicos presentes na pasta passem pelo processo de oxidação. 
No segundo caso, ou seja, a formação de margens claras ao redor do núcleo escuro sugere que o processo de oxidação dos elementos orgânicos foi iniciado, porém não concluídos. Nestes termos, apresento na Figura 19 as variações de cores nos planos de fratura segundo Orton e Hugues (2013).

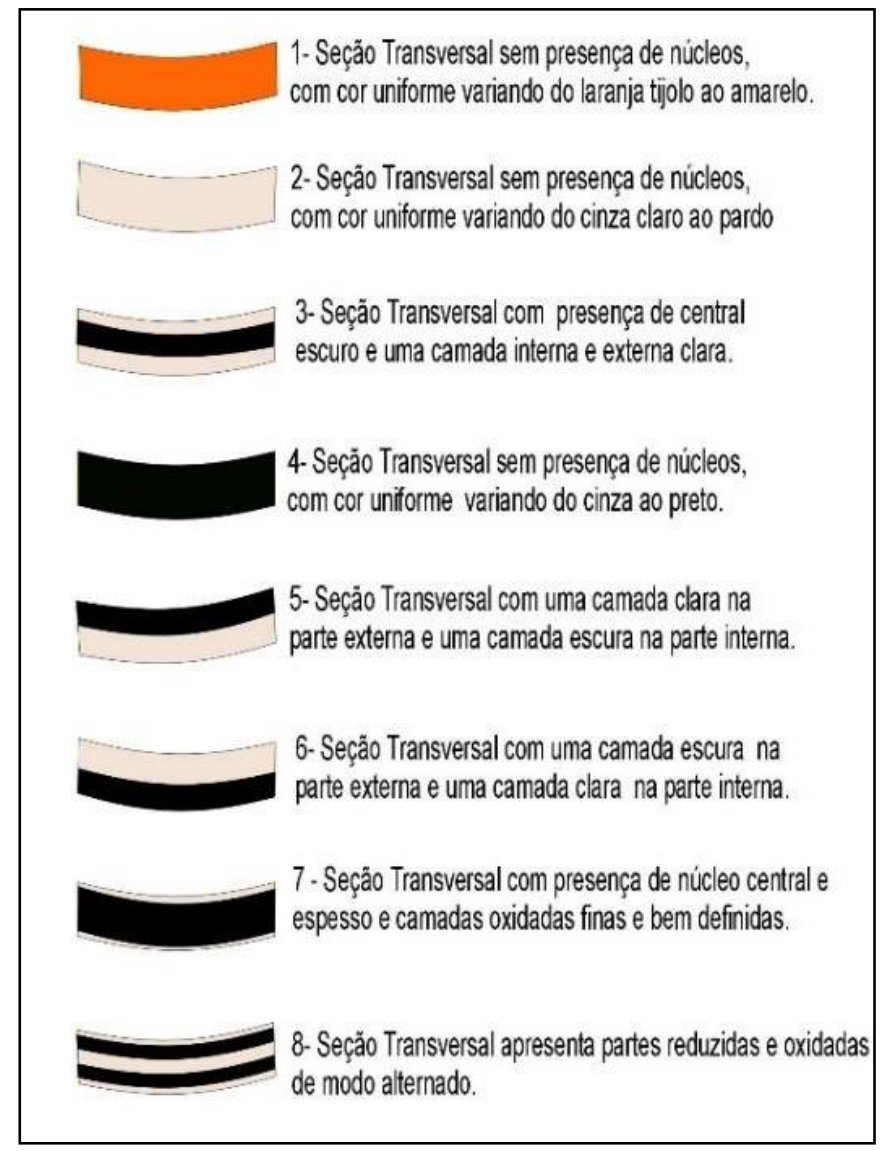

Figura 17: Classificação dos planos de fratura (MORAES, 2006: 11)

A presença de camadas claras e escuras pode sugerir que a boca do pote estava fechada de alguma forma, talvez por estar na posição emborcada no momento da queima, por exemplo.

Por fim, observam-se as cores das superfícies da vasilha, se forem diferentes das margens, provavelmente houve uma alteração de curta duração nas condições de queima. Este é o caso, por exemplo, de vasilhas que apresentam manchas pontuais na superfície.

No que diz respeito às vasilhas foco deste estudo, é notável a predominância de planos de fratura com coloração escura, ao passo que apenas $8 \%$ dos indivíduos apresentaram coloração clara e uniforme, como é possível notar no Gráfico 4. 


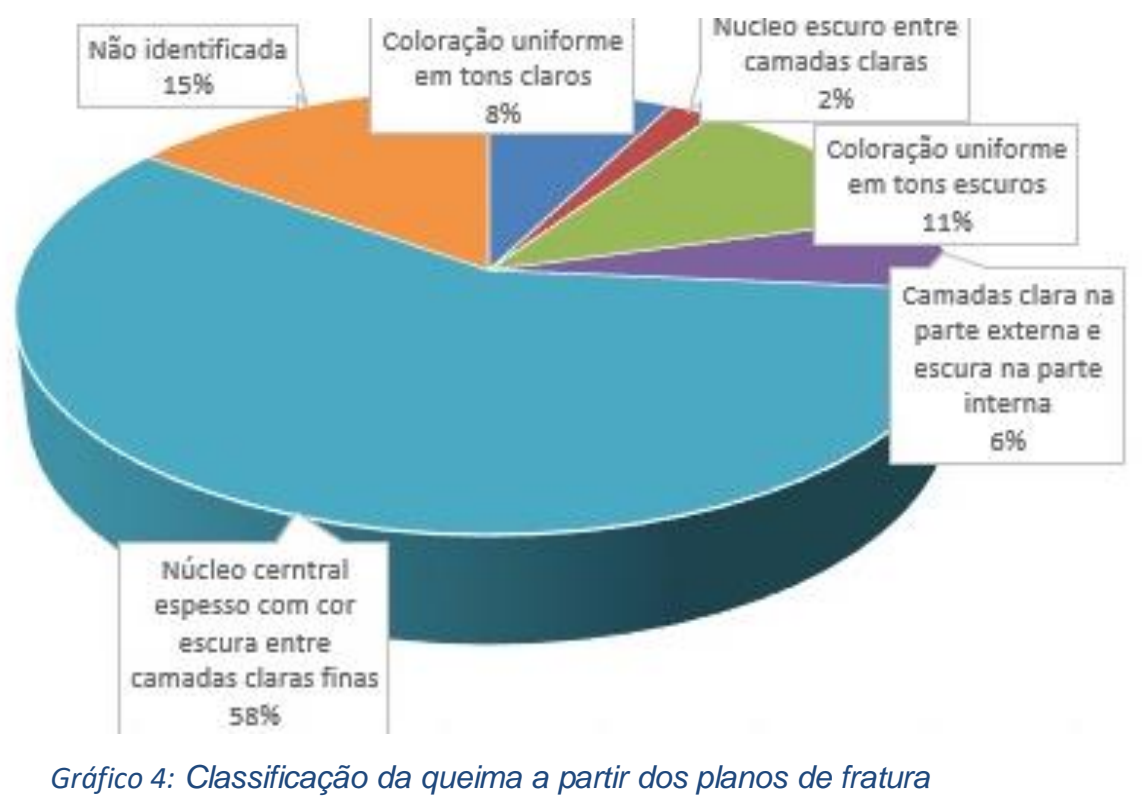

É válido ressaltar que em atmosferas oxidantes a distribuição de calor é irregular, bem como sua manutenção, o que pode resultar em diferentes graus de cozedura da pasta em uma mesma vasilha.

As evidências nos permitem levantar hipóteses acerca das estruturas de combustão utilizadas na queima das vasilhas, porém as formas de cozer podem ser diversas maneiras.

De acordo com Silva (2001), o processo de queima das vasilhas cerâmicas Assurini era realizada em duas etapas: a primeira acontecia em fogueiras aproveitando o calor do fogo destinado ao preparo de alimentos.

"Quando a vasilha está seca, elas a colocam perto do fogo ou sobre o fogo para fazer a queima inicial. Elas deixam a vasilha próxima ao fogo até ela ficar preta, aproximadamente durante meio dia. Normalmente elas aproveitam o fogo onde estão cozinhando" (SILVA, 2001: 67).

A segunda etapa acontecia em uma estrutura de fogueira preparada para a cozedura final vasilha.

"o processo de queima é relativamente simples, ou seja, elas arrumam uma base circular com tijolos ou vasilhas quebradas e no meio colocam as brasas. Depois apoiam a vasilha sobre esta base, com a boca virada para cima (...). Feito isso elas cobrem as vasilhas com as cascas da espata de babaçu, ou de outras madeiras" (SILVA, 2001: 68).

Para além dos aspectos produtivos, é interessante apresentar e reconhecer as semelhanças e diferenças de formas, pois, segundo Rice (1987) e Skibo (1992) a forma de um artefato está diretamente relacionada à função do mesmo, bem como podem ser um aspecto estilístico de determinados grupos. Por isso, 
dedicarei algumas páginas à descrição e quantificação das formas de bordas, bases e contornos que pude identificar nas vasilhas analisadas.

Vale ressaltar que 0 acesso a formas inteiras e bem preservadas em contextos arqueológicos é raro. Arqueólogos(as) partem da reconstituição gráfica de bordas e outros fragmentos diagnósticos (base, parede angular, etc.) para inferir possibilidades de formas e a partir delas desenvolver hipóteses acerca das dinâmicas sociais do passado. Neste contexto, pesquisas que se dedicam ao estudo de vasilhas inteiras podem se tornar uma referência para outros(as) pesquisadores(as).

Pensando nisso, optei por analisar a morfologia de bordas e bases, além da silhueta e estrutura das vasilhas, a fim de apresentar a variedade de formas no contexto regional.

No que compete às bases, apenas dois tipos foram identificados: bases convexas (arredondadas) e bases planas (Figura 18), sendo as primeiras as mais comuns, representando $62 \%$ da amostra, conforme indico no Gráfico 5 .

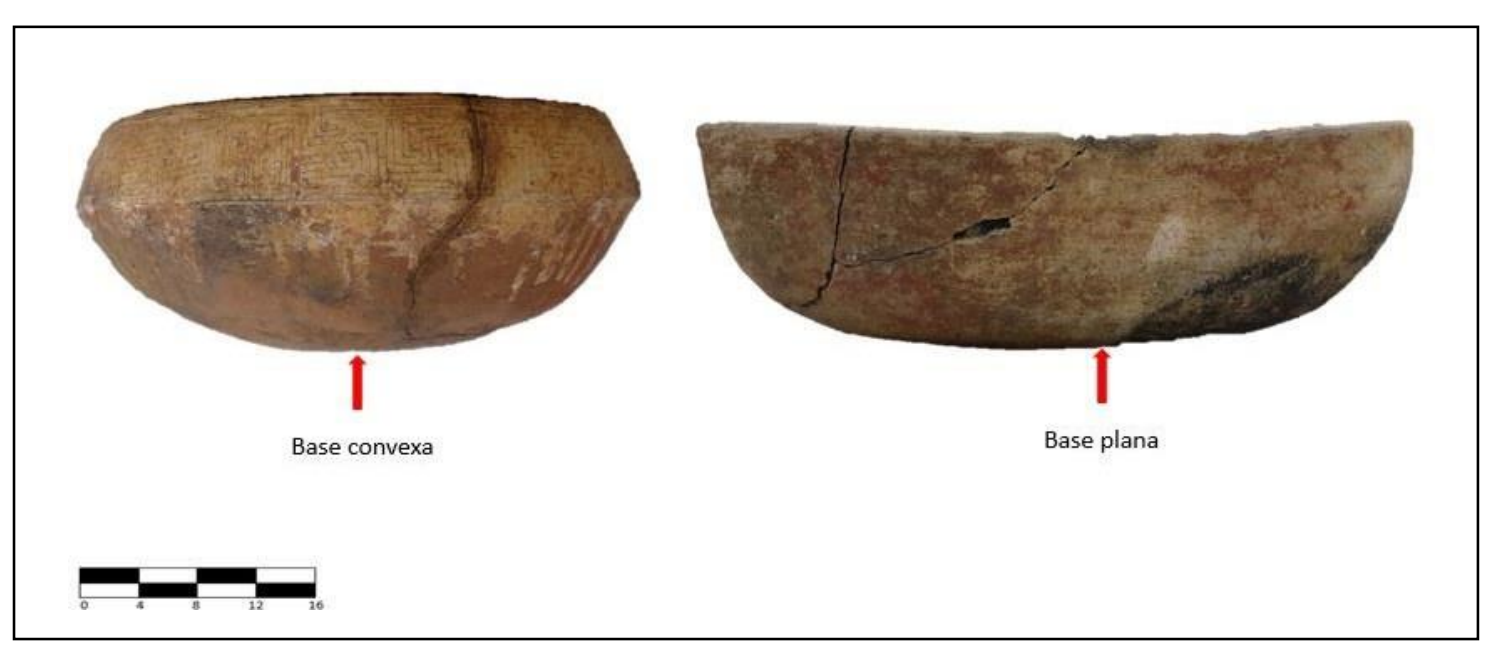

Figura 18: Morfologias de base 


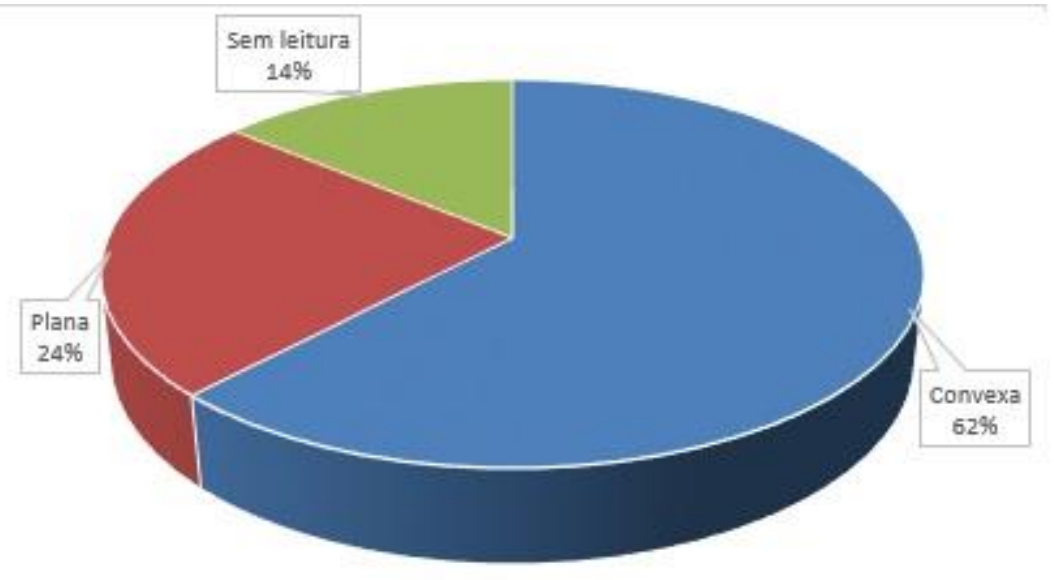

Gráfico 5: Morfologia de base

As bases convexas estão presentes em vasilhas restritas e, em alguns casos, vasilhas abertas. As bases planas, por outro lado, estão presentes apenas em vasilhas abertas. Algumas unidades (14\%) estavam com suas bases quebradas ou deterioradas demais para que sua morfologia fosse identificada.

A análise das bordas compreende $x$ atributos: morfologia, espessura em relação ao corpo, lábio e contorno da boca.

As morfologias, segundo Robrahn-González (2000) podem ser: Direta quando há continuação da curvatura do corpo, sem mudança de direção ou formação de ângulos; Infletida - quando apresenta uma mudança de direção em relação ao corpo, formando uma inflexão para fora; Introvertida (ou extrovertida) - quando apresenta uma mudança de direção em relação ao corpo, formando uma inflexão para dentro; Cambada - quando apresenta uma mudança de direção em relação ao corpo, formando dupla inflexão; Contraída - quando apresenta uma "quebra" na direção do contorno, formando um ângulo para dentro; Carenada - quando apresenta uma mudança na direção do contorno, formando um ângulo para dentro acompanhado de reforço externo. 


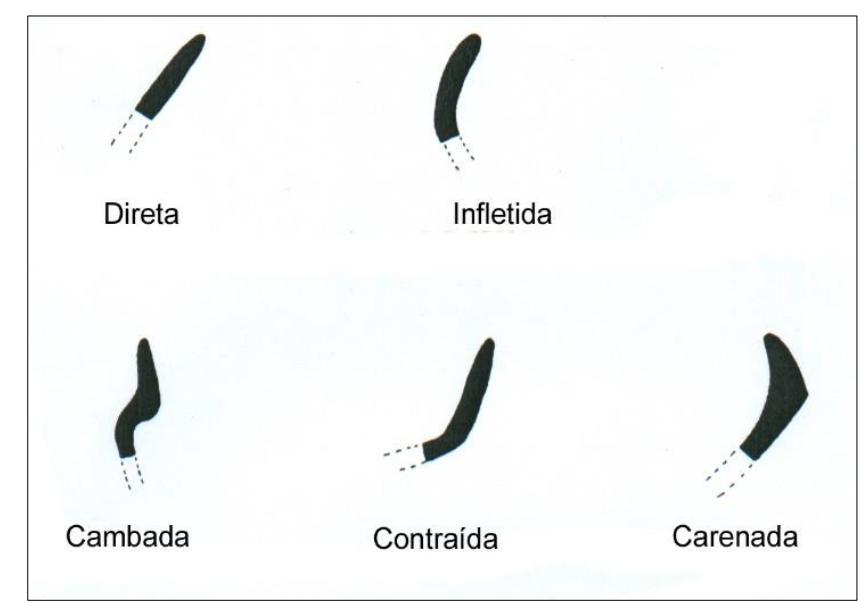

Figura 19: Morfologias de bordas segundo Robrahn-González (2000)

É possível notar no Gráfico 6 que o tipo de borda mais comum são as diretas, e que há uma certa equivalência entre as bordas do tipo extrovertida (Infletida), introvertida e cambada. Algumas vasilhas ainda apresentarem o lábio deteriorado, não sendo possível identificar sua morfologia.

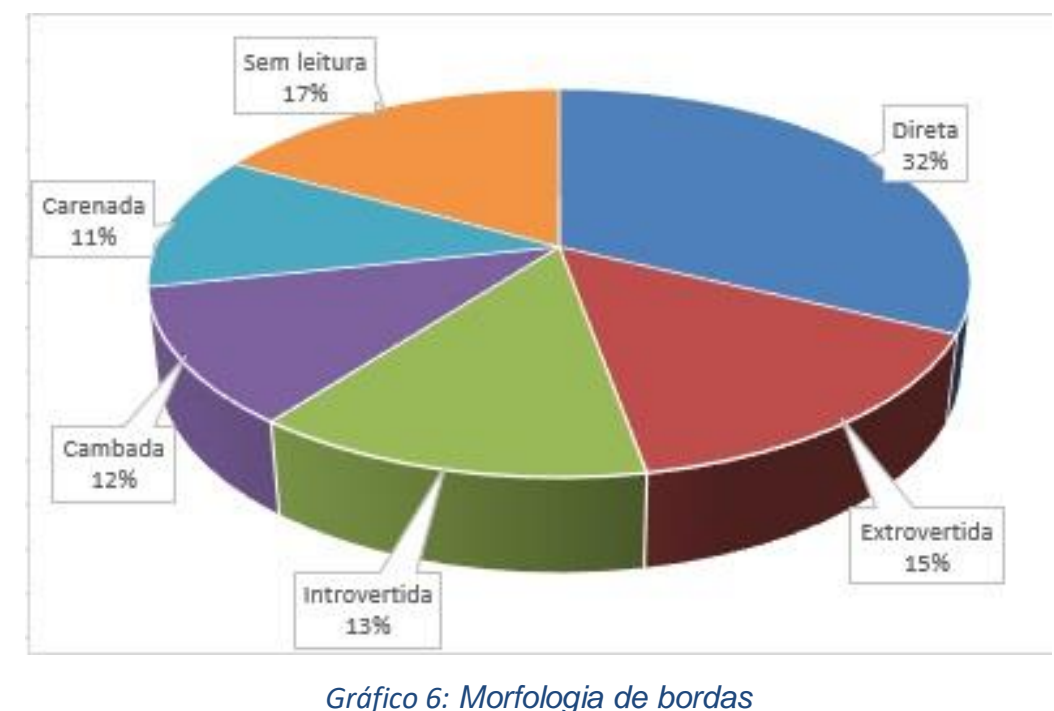

Gráfico 6: Morfologia de bordas

No que se refere à espessura das bordas em relação ao corpo da vasilha, a maioria apresentou a mesma espessura (64\%), no entanto, identifiquei uma quantidade significativa de bordas com algum tipo de reforço, como é possível notar no Gráfico 7. 


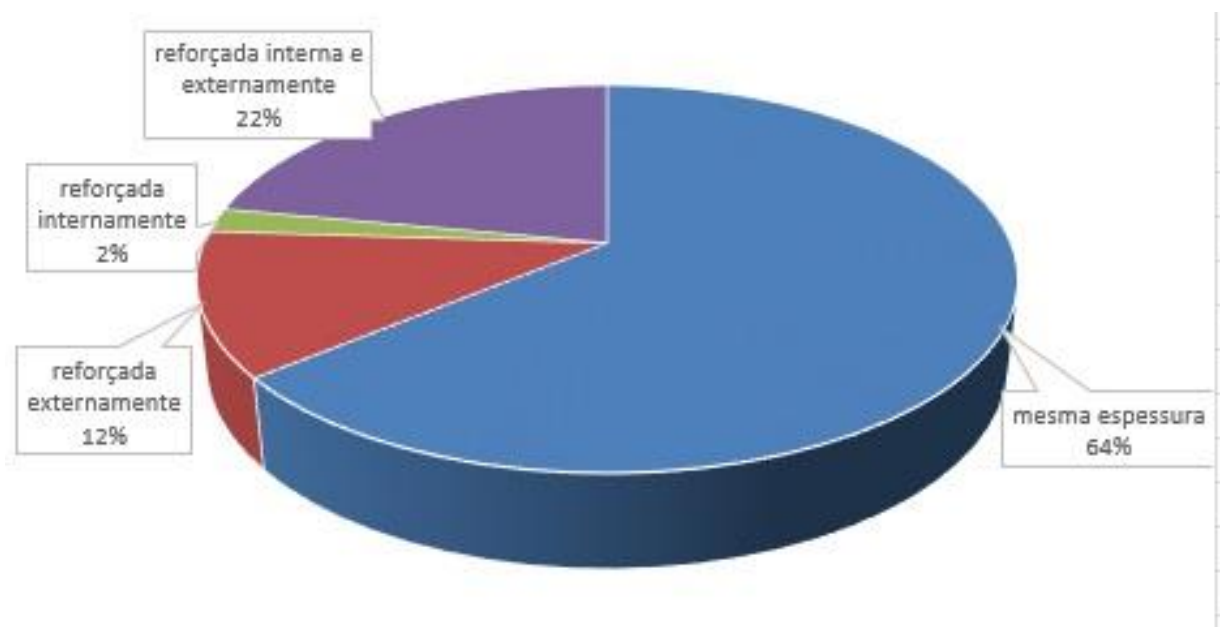

Gráfico 7: Espessura da borda em relação ao corpo

Gostaria de chamar atenção para os $22 \%$ de vasilhas que apresentaram bordas do tipo expandida, representando 11 unidades de análise, das quais 10 são provenientes do município de Canas e uma delas proveniente do município de Aparecida, ambas localizadas no vale do Paraíba. Este pode ser um traço de estilo regional.

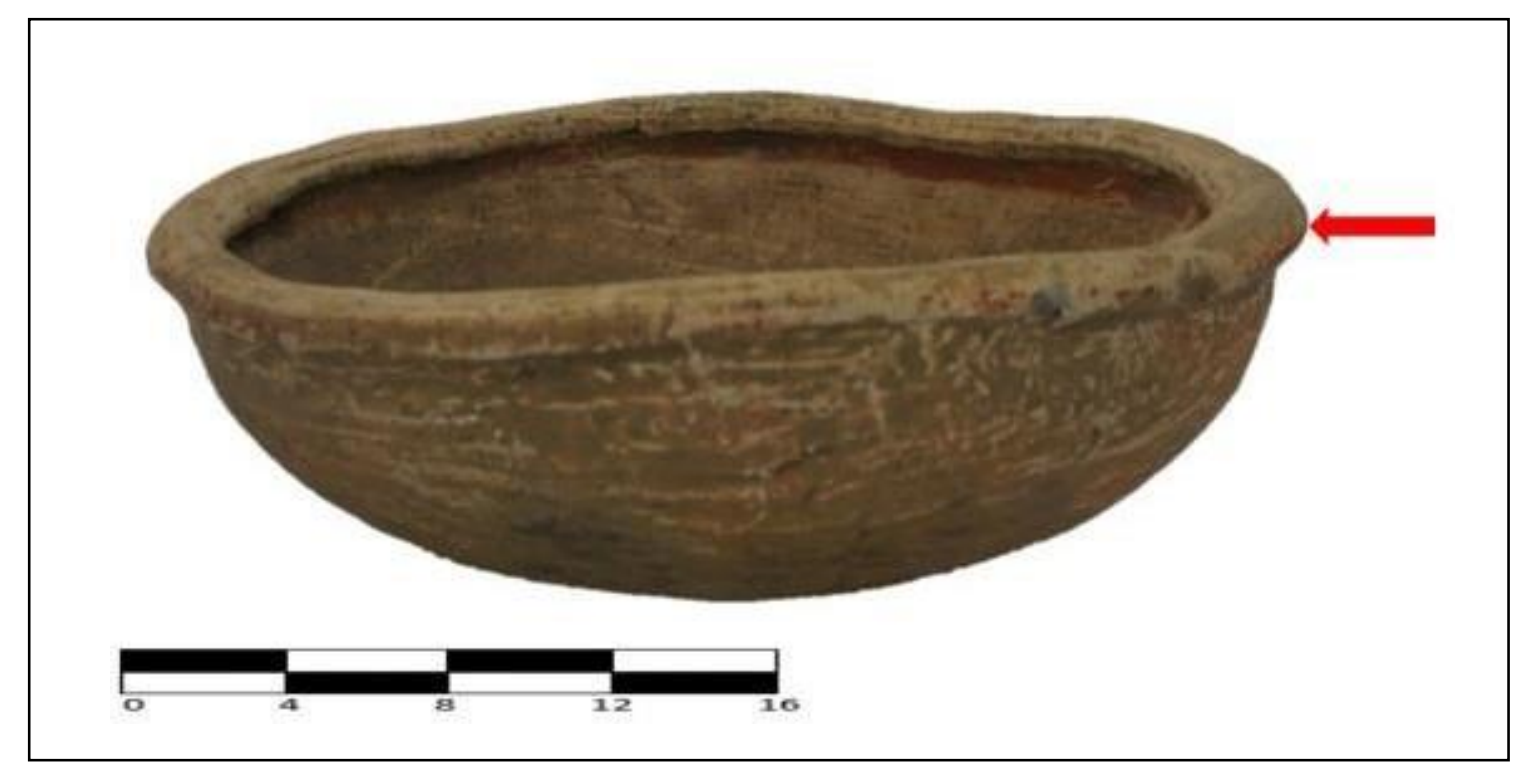

Figura 20: Vasilha cerâmica com borda expandida. MNSA 02

No que se refere ao tipo de lábio, pude identificar três formas: arredondado, plano e apontado, distribuídos conforme indicação do Gráfico 8. 


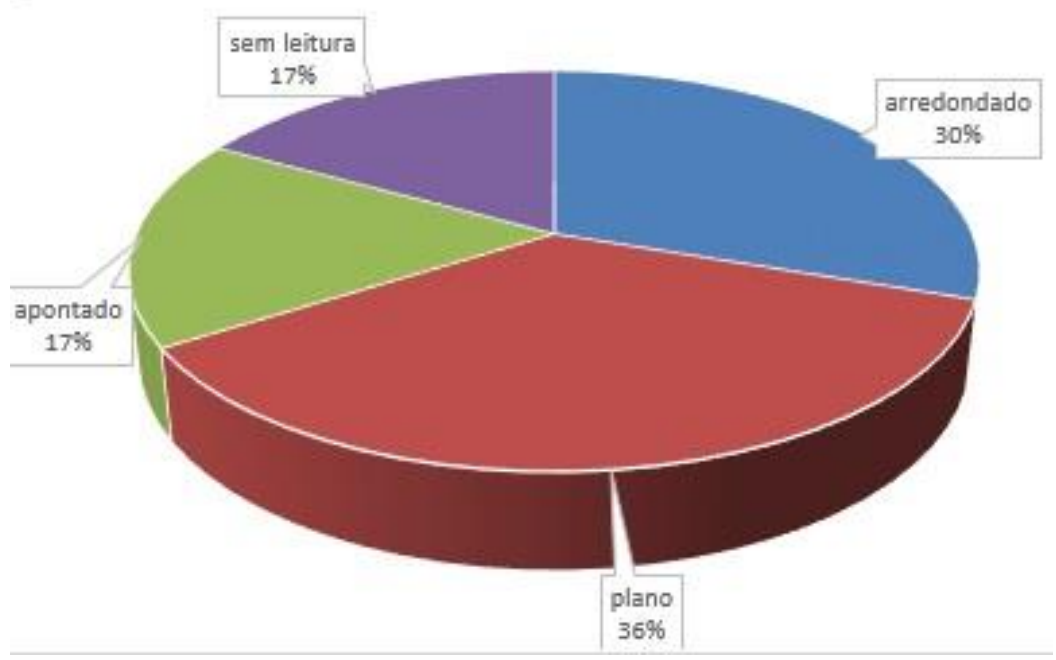

Gráfico 8: Morfologia de lábio

Os lábios do tipo plano são os mais recorrentes, no entanto, há também uma quantidade expressiva de lábios do tipo arredondado, ao passo que os lábios do tipo apontado estão presentes em apenas $17 \%$ das amostras. Mais uma vez, é possível observar peças cuja morfologia do lábio não foi identificada por apresentar parte da borda quebrada ou lábio gasto.

Outra característica morfológica observada e de suma importância para a análise é o contorno da boca, definida por Scatamachia (2004) como a linha que delimita a boca da vasilha. Ao observar o recipiente no seu plano superior ( $p$. 293). Pude identificar quatro formas, a saber: circular, elíptica, quadrangular ou retangular (Figura 21).

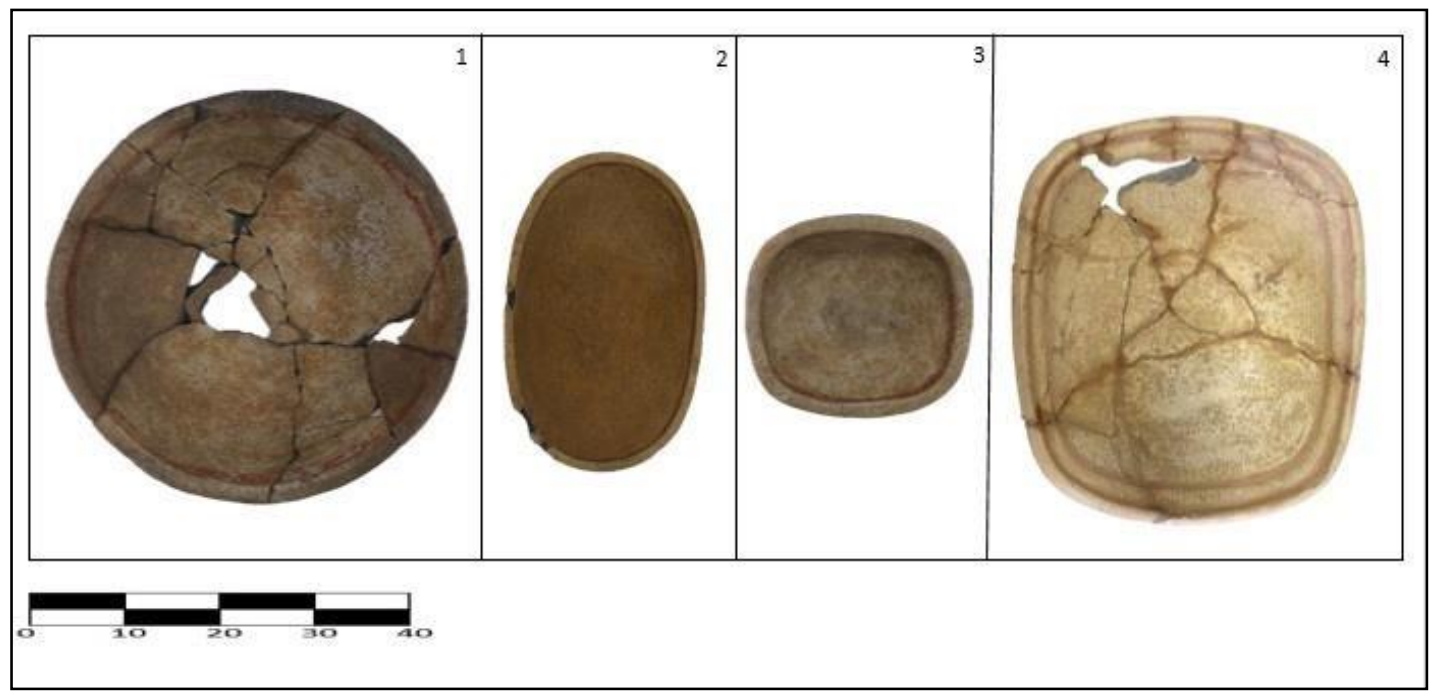

Figura 21: Morfologias contorno de boca: 1. Circular (FCJ 07); 2. Elíptica (MNSA 04); 3. Quadrangular (FCJ 02); 4. Retangular (MHS 03) 
Como é evidenciado no Gráfico 9, a grande maioria das vasilhas apresentaram contorno da boca com formato circular, presente em vasilhas de grande, médio e pequeno porte, sejam elas restritas ou abertas. As bocas com contorno elíptico, quadrangular e retangular, esta última identificada em uma única vasilha, estão presentes apenas nas vasilhas abertas, todas provenientes da porção leste do estado.

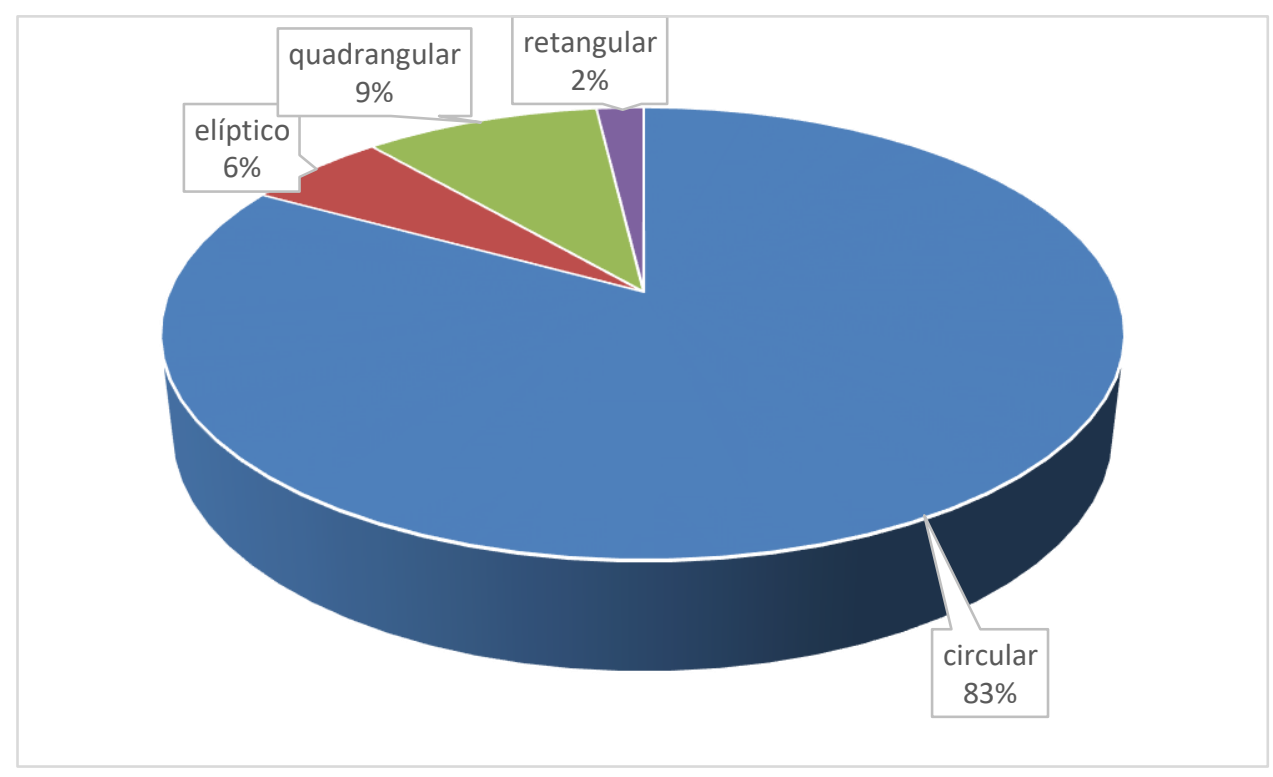

Gráfico 9: Contorno da boca

No que se refere às características gerais dois atributos são relevantes: contorno da vasilha e estrutura geral.

Alguns autores (SHEPARD, 1971; CHMYZ, 1976; LA SALVIA \& BROCHADO, 1989. SCATAMACHIA, 2004) consideram a quantidade de pontos (ângulos) de junção das vasilhas para definir a silhueta em: simples, àquelas que não possuem ângulos, se aproximando de formas básicas geométricas; composta, àquelas que possuem um ângulo de junção de duas partes do vaso; e complexa, àquelas que apresentam dois ou mais ângulos de junção (Figura 22). 


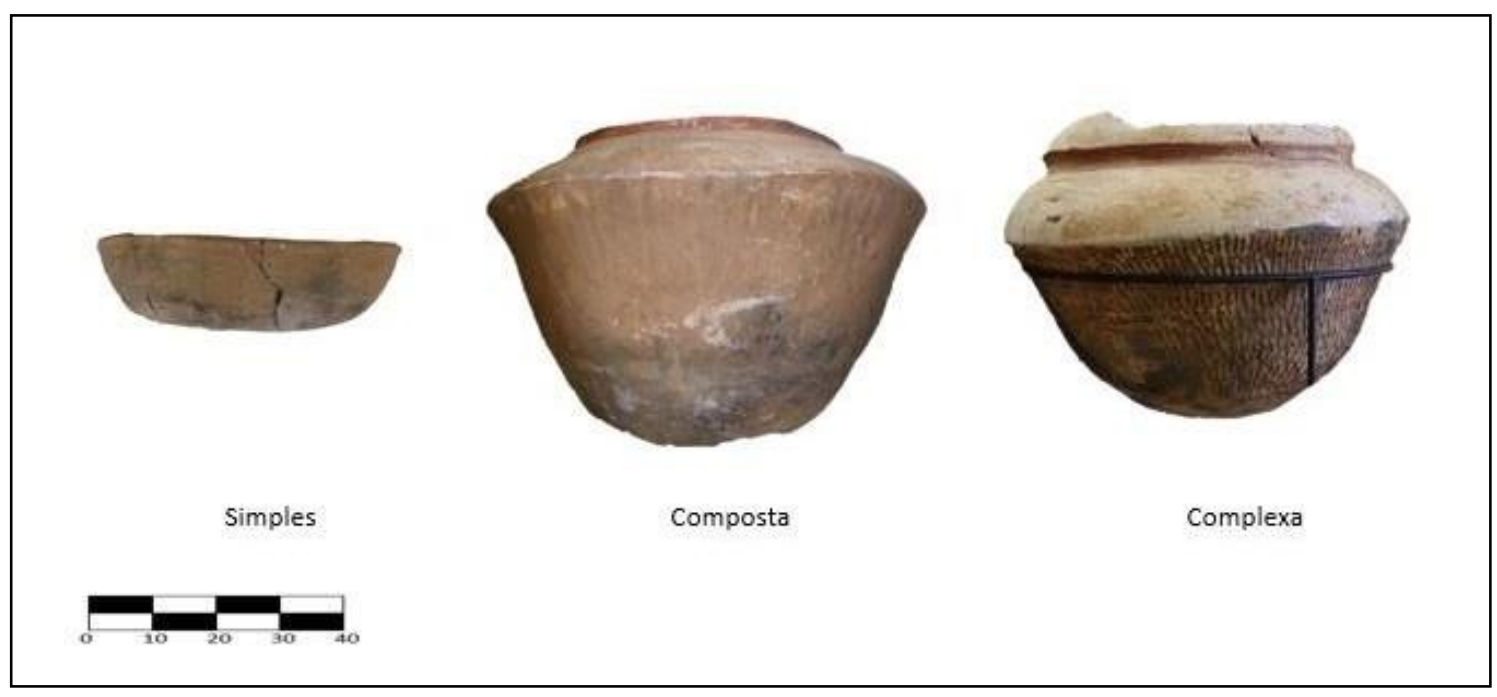

Figura 22: Contorno das vasilhas (CEMAARQ 04; FCJ 05)

Em minhas amostras, 28 vasilhas (53\%) foram caracterizadas como formas compostas, 21 vasilhas $(40 \%)$ apresentaram contorno simples e, apenas 4 vasilhas (7\%) apresentaram contorno complexo, como fica evidente no Gráfico 10.

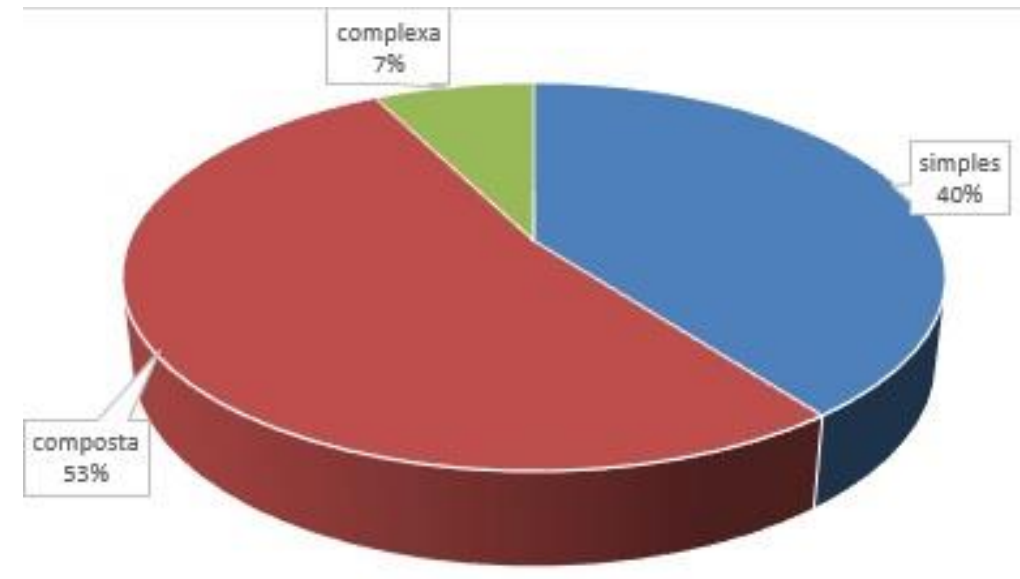

Gráfico 10: Contorno da vasilha

Sobre a estrutura geral da vasilha, Shepard (1971) apresenta diversas classes, considerando o diâmetro da boca em relação ao corpo, as quais podem ser resumidas em apenas três, considerando o ângulo de inclinação da borda: vertical, quando a borda apresenta um ângulo de $90^{\circ}$ em relação à base; restrita/fechada, quando a borda apresenta angulação inferior a $90^{\circ}$; e aberta, quando a borda apresenta angulação superior a $90^{\circ}$.

De maneira geral as vasilhas que analisei apresentaram estruturas fechadas (com ângulos inferiores a $90^{\circ}$ ), entre as quais optei por subdividi-las em dois grupos: vasilhas levemente restritas (diferença entre a maior largura e o 
diâmetro da boca é suave) e vasilhas restritas (cujo diâmetro da boca é muito inferior à medida da maior largura), pois acredito que as funções para cada caso são diferentes (consumo e armazenagem, respectivamente). Há ainda vasilhas abertas (nas quais a maior largura identificada é justamente o diâmetro da boca) em menor proporção (28\% das amostras) como fica evidente no Gráfico 11.

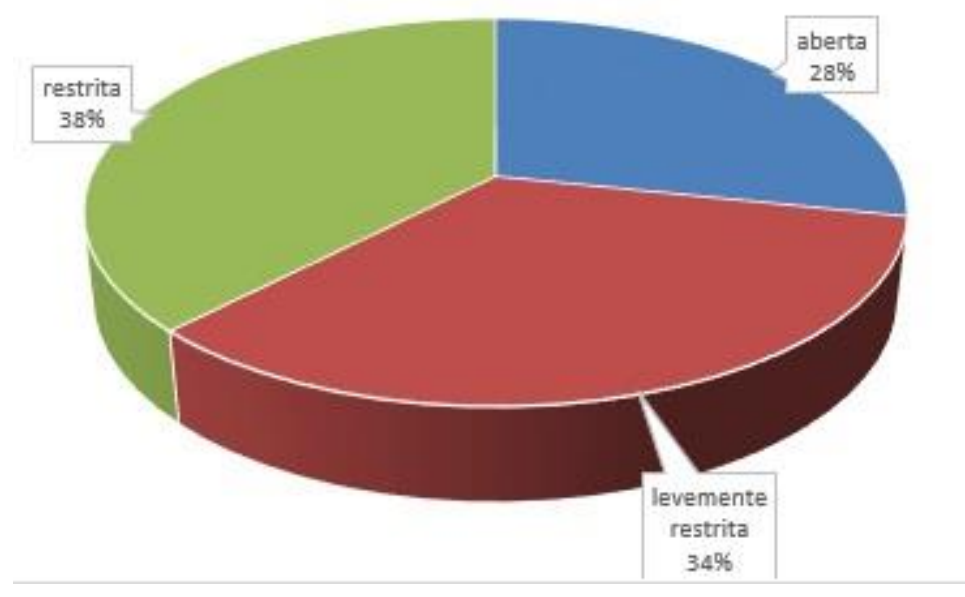

Gráfico 11: Estrutura geral da vasilha

Este atributo pode ser decisivo para que possamos compreender em qual/quais contextos sociais circulavam as vasilhas produzidas.

Assim, considerando a vasta bibliografia existente sobre estudos cerâmicos em contextos associados à ocupação de populações Tupi (LA SALVIA \& BROCHADO, 1989; NOELLI, 1993; BROCHADO \& MONTICELLI, 1994; MORAES, 2007; CORRÊA, 2014; LOPES, 2014), identifiquei três classes de vasilhas entre àquelas que foram alvo de estudo em meu mestrado, são eles: Cambuchí (jarras para bebidas), Cambuchí caguãba (tigelas para beber) e ñaembé ou teembirú (pratos para comer).

A partir destas categorias agrupei as vasilhas em epígrafe considerando sua forma e função presumida (Pranchas 02, 03 e 04). Estas, assim como outras tantas, foram identificadas pelo Padre Antônio Ruiz Montoya no século $X V I I$ durante o período em que viveu em reduções jesuíticas no Paraguai. $O$ sacerdote se dedicou ao estudo da língua Tupi-Guarani, sendo reconhecido atualmente como o criador da linguística Guarani a partir de sua obra "Tesoro de la lengua Guarani", publicada em 1639. 


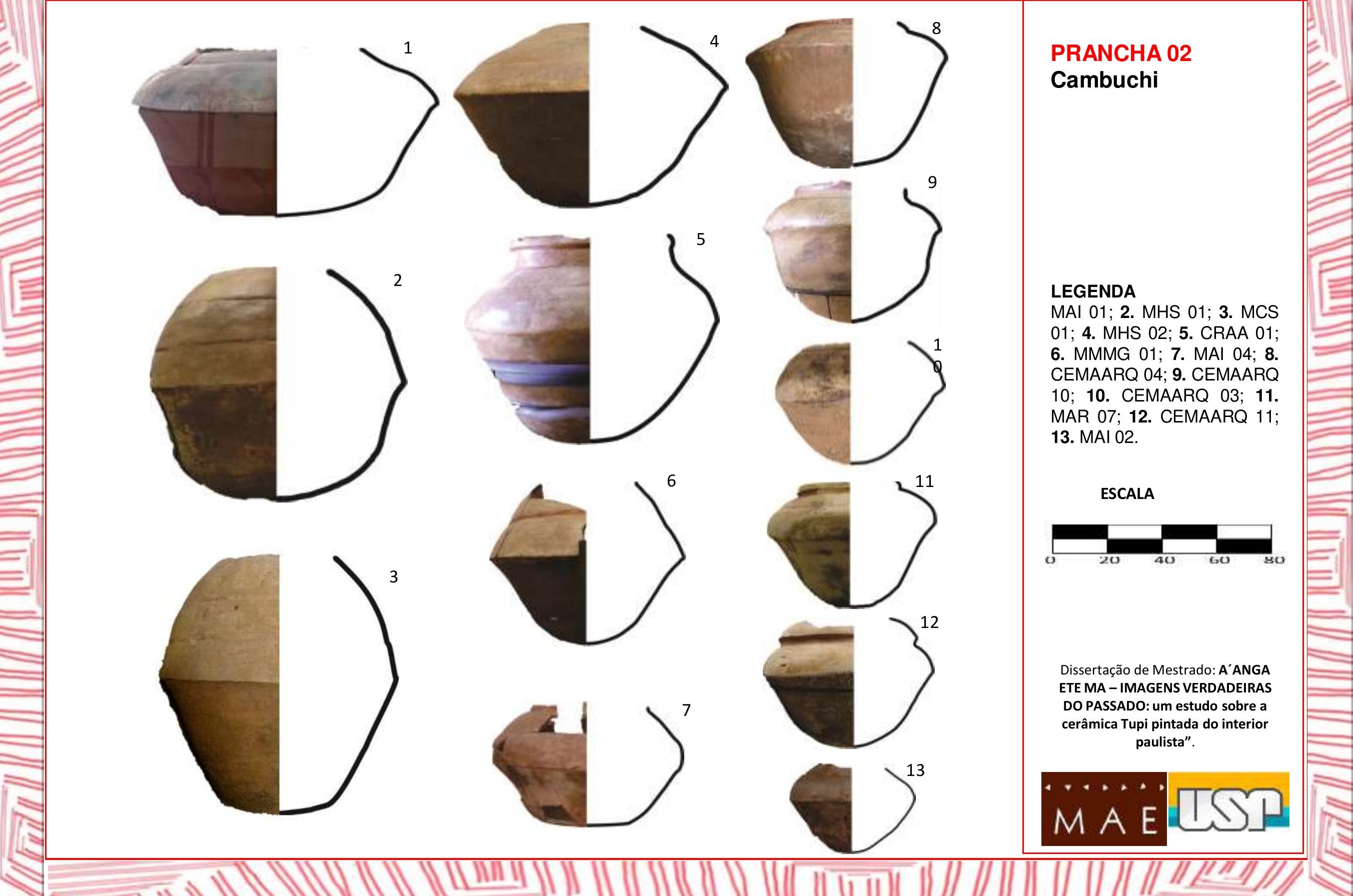



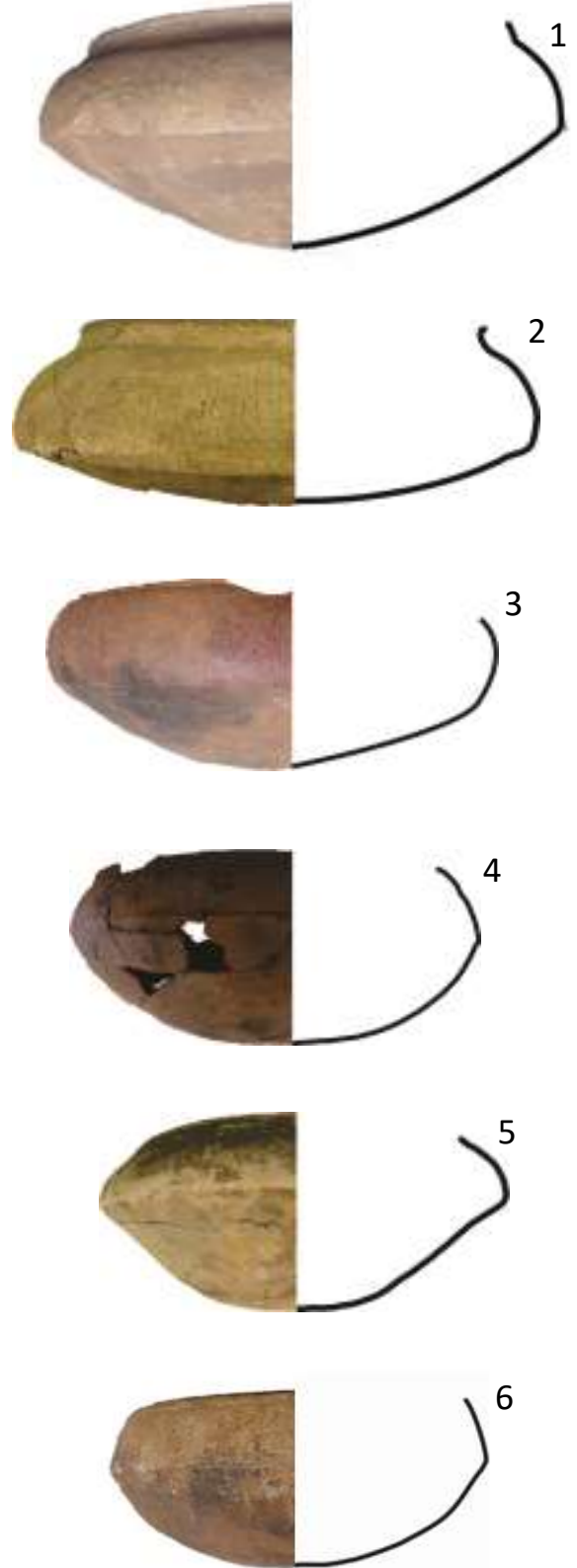
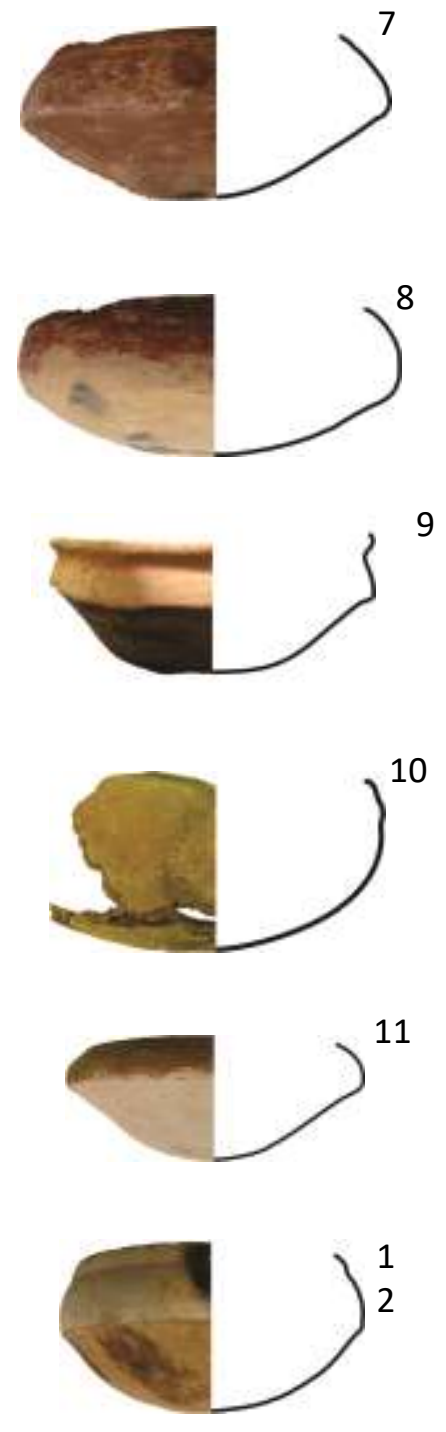

PRANCHA 03

\section{Cambuchi caguaba}

\section{LEGENDA}

1. CEMAARQ 09; 2. MAR 01; 3. MAR 05; 4. CRAA 04; 5. MAR 04; 6. CRAA $02 ; 7$. CRAA 03 ; 8. CEMAARQ 08; 9. MHS 04; 10. MAR 02; 11. MAR 03; 12. MAR 06.

\section{ESCALA}

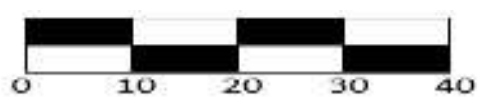

Dissertação de Mestrado: A'ANGA ETE MA - IMAGENS VERDADEIRAS DO PASSADO: um estudo sobre a cerâmica Tupi pintada do interior paulista".

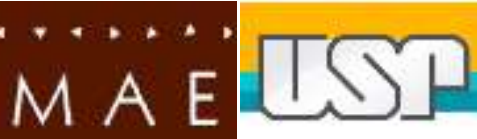




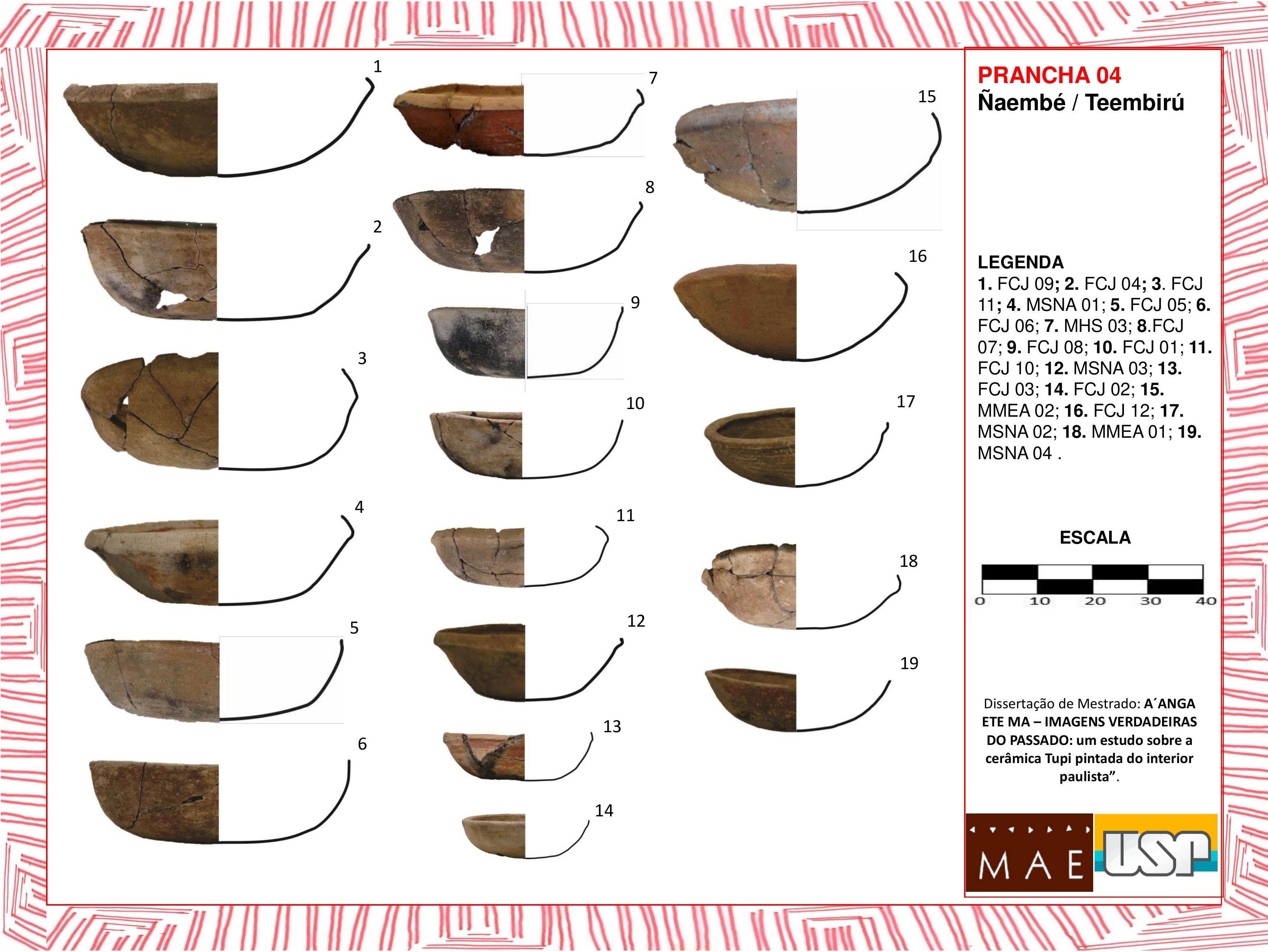


As classes de utensílios cerâmicos identificados por Montoya foram revistas por La Salvia e Brochado (1989), Noelli (1993) e Brochado e Monticelli (1994), que identificaram algumas classes básicas de vasilhas, considerando suas funções essências: cozinhar, armazenar, servir e consumir.

As três categorias que integram este estudo, de acordo com Montoya (1639), circulam em ambientes rituais, sendo destinadas ao preparo e armazenamento de bebidas alcoólicas (no caso dos cambuchí), ao consumo destas bebidas (no caso dos cambuchí caguãba) e no consume coletivo de comidas em ocasiões festivas (ñaembé / teembirú).

No que se refere às dimensões, observei as seguintes medidas: diâmetro da boca, maior largura e altura, a partir das quais notei certa variação em algumas classes de vasilha, como fica evidente no Gráfico 12.

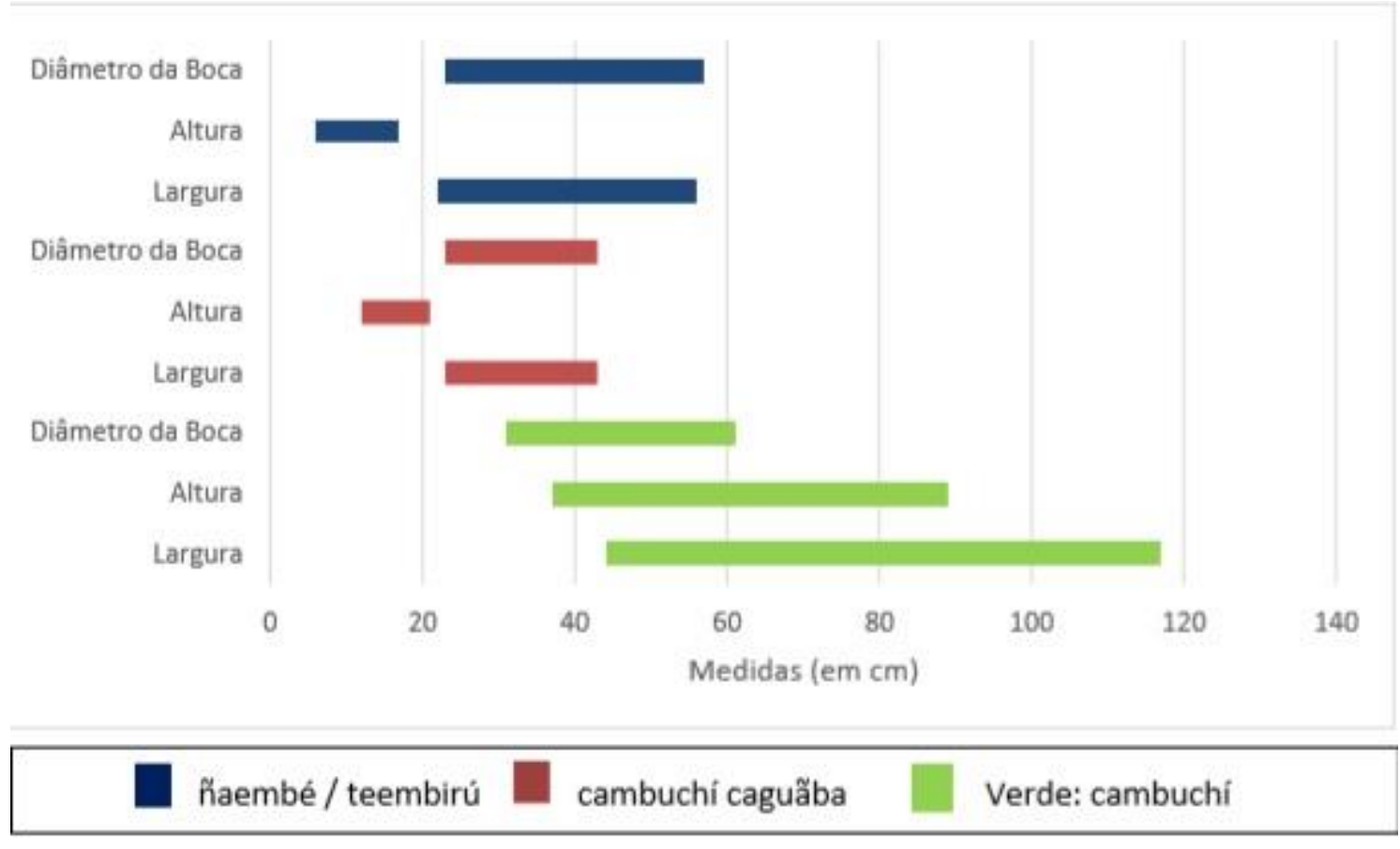

Gráfico 12: Variação de diâmetros da boca, alturas e larguras por tipos de vasilha

As vasilhas do tipo cambuchí são as que apresentam maior variação em altura e largura, variando também em proporções e contornos, como já expus anteriormente. As vasilhas do tipo cambuchí caguãba, por outro lado, apresentam unidades mais homogêneas. Por fim, as vasilhas do tipo ñaembé / teembirú apresentam pouca variação no que se refere à altura e contornos, no entanto, no que compete à largura (diâmetro da boca), variam entre 23 a 56 $\mathrm{cm}$, podendo indicar variação nas formas de consume (individual ou coletivo). 
Tendo apresentado os aspectos morfológicos das vasilhas analisadas, passo agora à segunda parte da exposição, centrada nos conjuntos decorativos e sua função simbólica dentro do grupo.

\section{$\underline{\text { Parte } 2}$}

Os estudos de arqueologia brasileira além da região amazônica, no que diz respeito à cerâmica, tem se concentrado principalmente em aspectos tecnológicos que permeiam a produção oleira, a fim de levantar hipóteses sobre os modos de vida de populações pré-coloniais, levantando questionamentos sobre dietas alimentares, agricultura, manejo dos recursos naturais, densidade populacional, entre outros. Neste contexto, aspectos subjetivos da cultura como relações de poder, representatividade e identidade de grupo ficam em segundo plano.

De maneira pontual os trabalhos que se dedicam ao estudo das decorações cerâmicas for a da Amazônia se limitaram a descrição e classificação de pinturas e texturas. No máximo estabelecem a relação entre forma, aspectos decorativos e função.

Talvez este fato esteja relacionado à escassez de vestígios que permitam estudos aprofundados sobre o tema, uma vez que muitos contextos foram intensamente impactados pela ação colonizadora; talvez os(as) arqueólogos(as) não veem beleza (ou arte) em todos os utensílios cerâmicos; talvez os(as) pesquisadores(as) estejam mais preocupados em compreender aspectos gerais de uma cultura do que suas particularidades e subjetividades; talvez os(as) arqueólogos(as) brasileiros não tenham familiaridade com correntes teóricas que valorizem a subjetividade da cultura a agentividade do artefato.

Acredito que estudos que dediquem maior atenção à arte indígena, e neste caso trago especificamente o caso das pinturas em cerâmicas, possam levantar algumas hipóteses interpretativas sobre aspectos subjetivos dos povos do passado.

Antes de apresentar os dados que obtive com a análise das vasilhas cerâmicas em questão, convém aqui esclarecer alguns pontos-chave sobre os 
traços estilísticos que são marcantes nas pinturas identificadas em determinadas vasilhas cerâmicas produzidas por diversos povos de matriz cultural Tupi.

O primeiro diz respeito à forma como as ceramistas percebem as vasilhas e, consequentemente, concebem os motivos decorativos em setores. A ceramista aplica os motivos no campo visual mais atraente ao observador, geralmente na face externa, na parte superior em vasilhas restritas (nestes casos os motivos cobrem a área que vai da borda ao ombro/carena) e na face interna em vasilhas abertas. Estes padrões deixam claro a intenção da ceramista em produzir motivos para serem vistos e notados, uma vez que os motivos se encontram em setores da vasilha aos quais temos contato visual direto.

A parte da vasilha que recebe os motivos pode receber diversos nomes. Oliveira (2008) estabelece uma distinção entre "campo" e "zona", sendo o primeiro termo utilizado para denominar o motivo principal (o mais complexo) e o segundo termo é utilizado para denominar os motivos complementares. Optei neste trabalho por utilizar os termos "campo primário" e "campo secundário" para designar os motivos principais e complementares, respectivamente, adotando a proposta de Moraes (2007). Estes campos são delimitados por linhas e/ou faixas acima e abaixo, denominadas bandas.

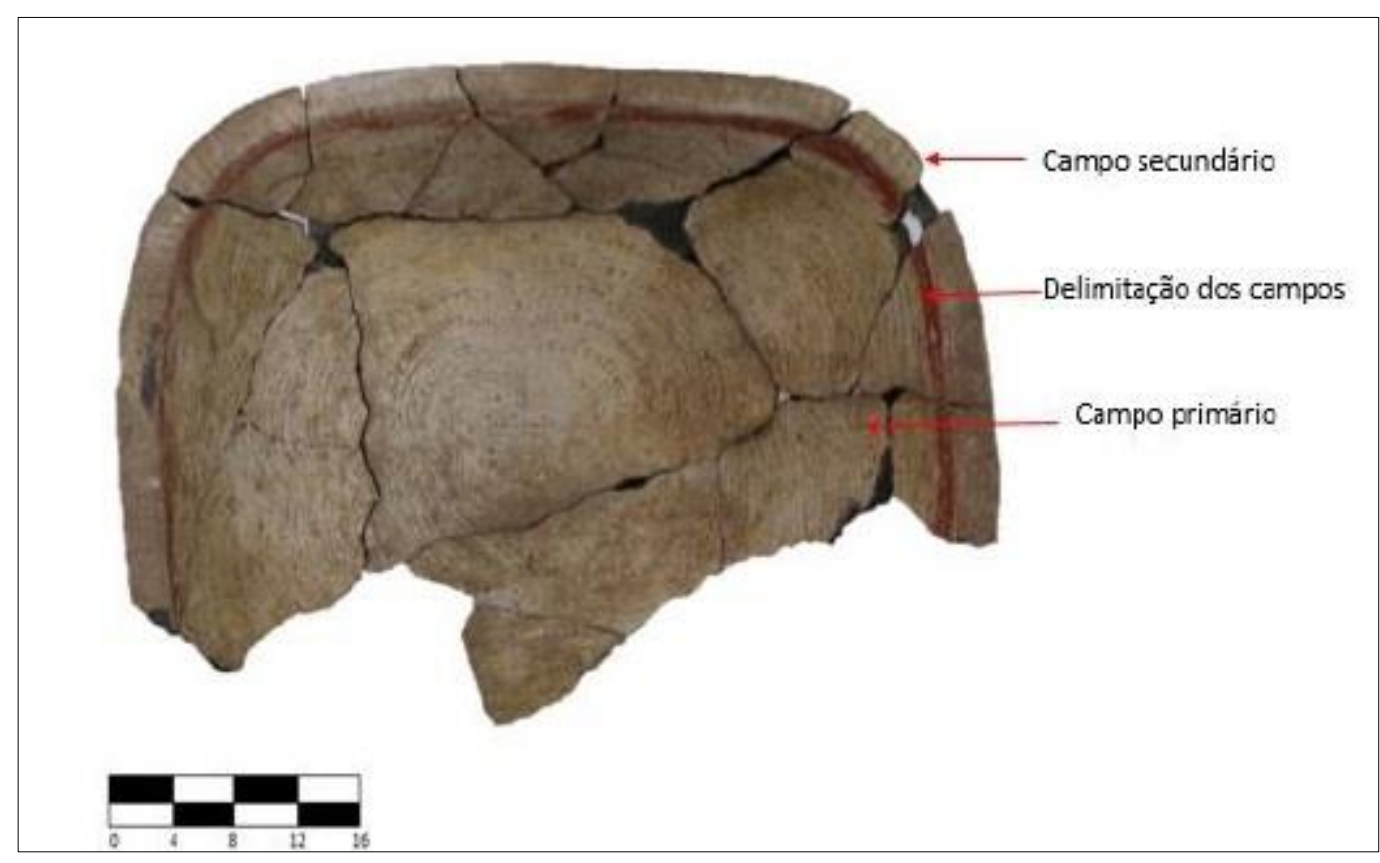

Figura 23: Vasilha com campos gráficos na face interna (FCJ 04) 


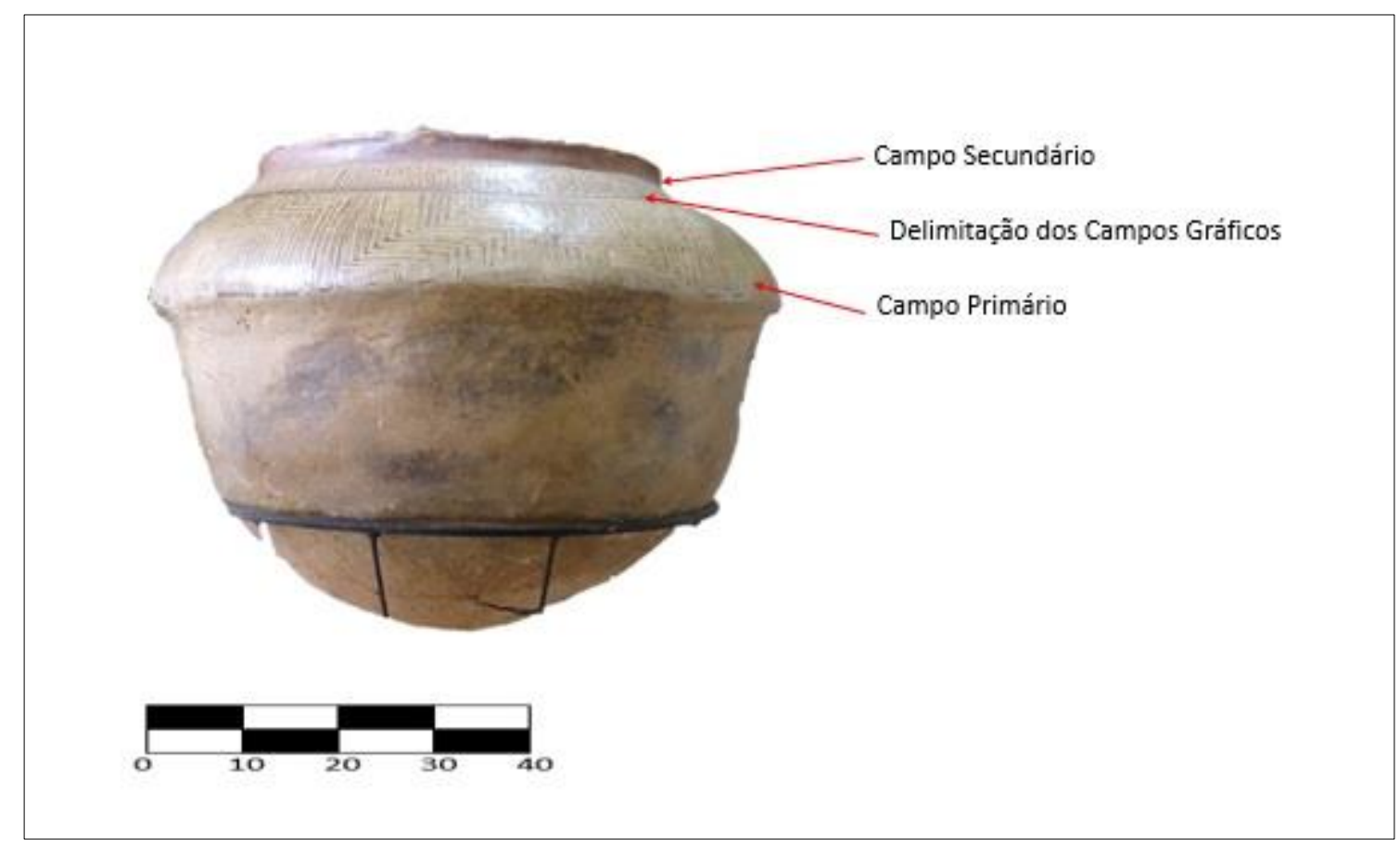

Figura 24: Vasilha com pintura na face externa (CEMAARQ 10)

La Salvia e Brochado (1989) propõem uma interpretação para este padrão considerando a forma e função das vasilhas. Assim, no caso das vasilhas do tipo cambuchí, a pintura era aplicada na parte superior, pois a parte inferior, quando em uso, permanecia enterrada ou presa em um jirau e, portanto, não eram vistas e por isso não recebiam pintura. Também observei a ocorrência de vasilhas que possuíam engobo vermelho na parte inferior, provavelmente aplicado para impermeabilizar a parte da vasilha que permaneceria em contato direto com a terra. Já as vasilhas do tipo cambuchí caguâba, utilizadas no consumo de líquidos, apresentariam a pintura na parte superior da face externa, ao passo que sua parte inferior, onde as pessoas acomodariam as mãos, permaneceria alisada.

Segundo os autores, os motivos se alternam entre bordas e bojo (ou zona central, no caso de vasilhas abertas), de acordo com a função de armazenar e servir.

\footnotetext{
"O que é mais importante, a borda ou o bojo? Por um se expele, no outro guarda-se o conteúdo. Razão pela qual motivos se alternam na medida em que se modifica o momento das estilizações. Os motivos seriam semelhantes, mas nunca iguais e sua alternância demonstraria a mesma força das entidades espirituais sobre o que faze, de sua força e da forma em que agem" (LA SALVIA \& BROCHADO, 1989: 95)
}

No que compete às cores utilizadas na produção cerâmica, segundo Oliveira (2008), é possível notar a presença constante de três cores, as quais 
aparecem em múltiplas variações de tonalidades, seja por influência de sua composição ou ainda como resultado de processos pós-deposicionais. São elas: preto, vermelho e branco.

Para Prous $(2005,2009)$, estas cores podem ser entendidas como expressão de categorias de pensamento mais amplas. Assim, utilizando dos termos do vocabulário Tupi-guarani para designar as cores utilizadas na pintura cerâmica, o autor percebe a intenção em representar: Cores Muito Escuras: como o preto e o marrom escuro frequentemente utilizadas para a produção de desenhos ponteados; Cores Escuras: como o vermelho escuro e o preto, utilizadas para traçar linhas; Cores Intermediárias: como o vermelho, utilizadas para pintar o lábio e demarcar os limites entre os campos gráficos (bandas); Cores Muito Claras: como o branco, utilizadas como pano de fundo para a produção dos grafismos, conferindo destaque a eles.

É importante salientar que entre as cores utilizadas na produção dos grafismos existem duas possibilidades: escuro, geralmente um vermelho mais escuro do que àquele utilizado para a delimitação dos campos com bandas (Figura 25) e muito escuro, geralmente preto (Figura 26). Também há casos em que os motivos são feitos a partir da combinação de cores escuras e muito escuras (Figura 27). 


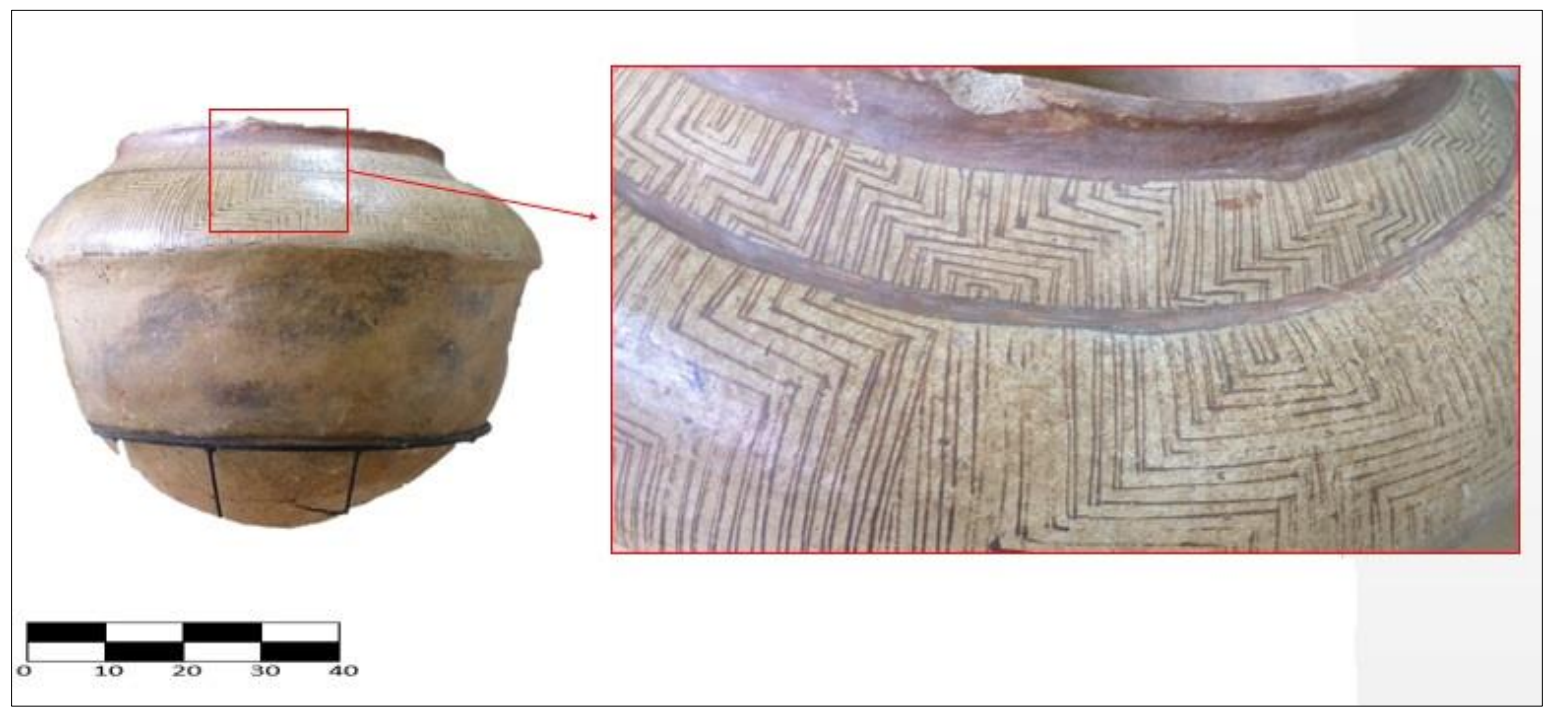

Figura 25: Vasilha com motivos feitos com cor escura - vermelho (CEMAARQ 10)

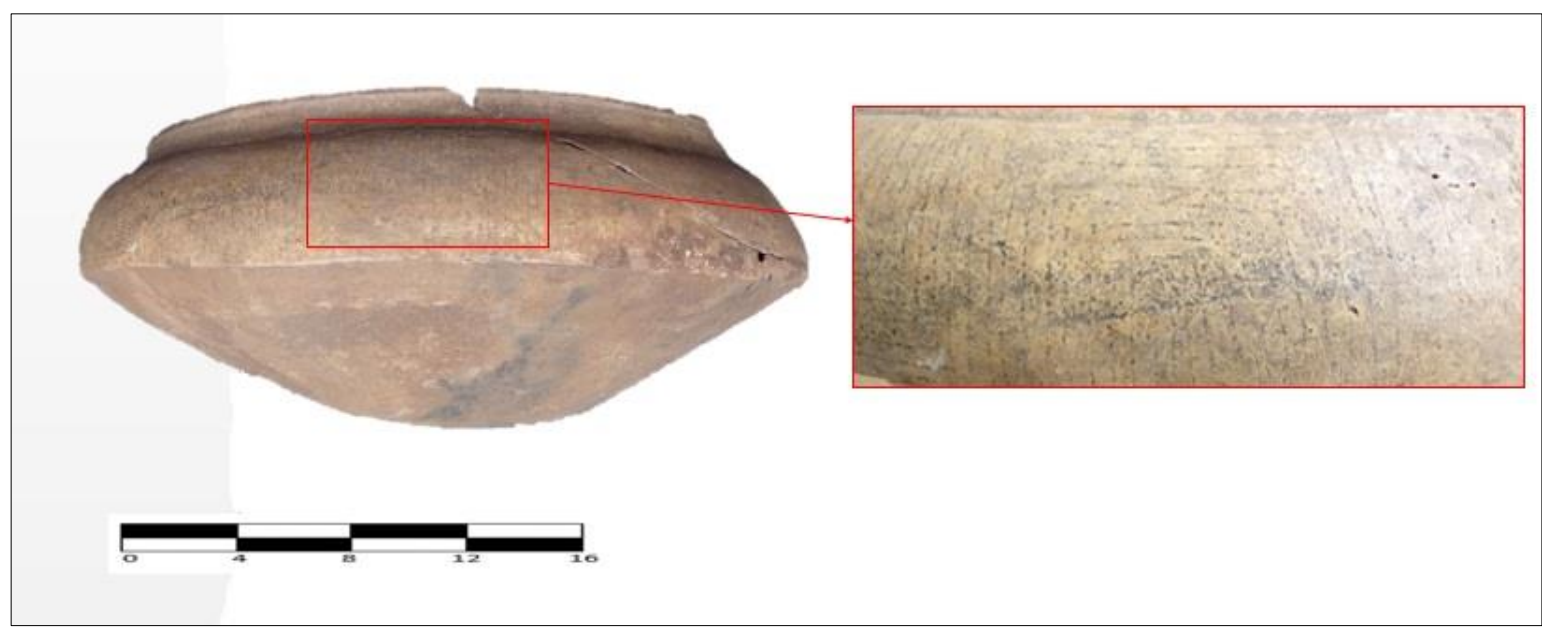

Figura 26: Vasilha com motivos feitos com cor muito escura -preto (CEMAARQ 09)

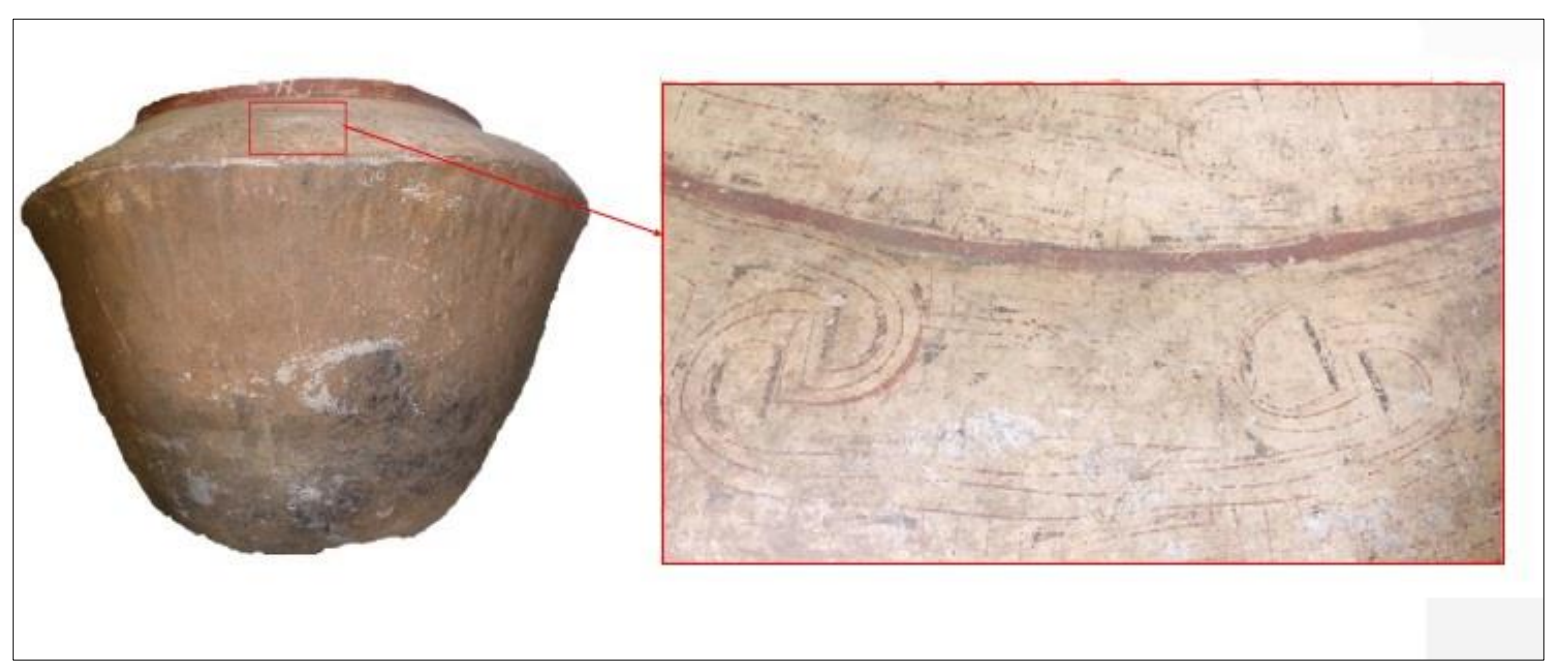

Figura 27: Vasilha com motivos feitos com cor escura e muito escura (CEMAARQ 04) 
Notei nas amostras a preferência das ceramistas em produzir grafismos em cores muito escuras, seja nos campos primários ou secundários. Dez vasilhas apresentaram motivos que combinavam cores escuras e muito escuras no campo primário, ao passo que apenas duas vasilhas apresentaram a mesma combinação de cores para o campo secundário (Gráfico 13).

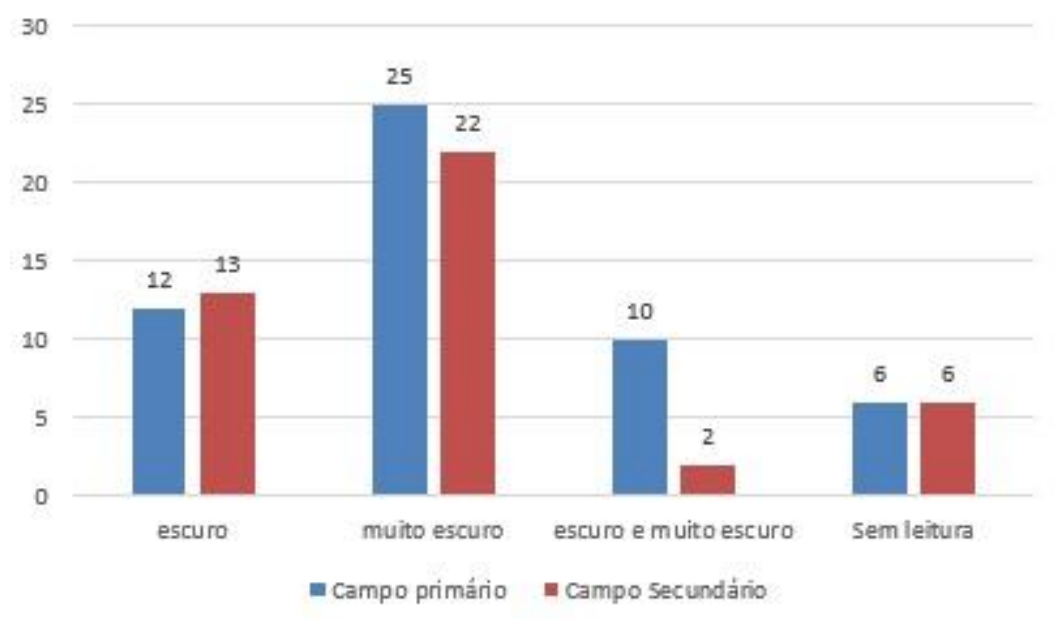

Gráfico 13: Cor dos motivos

No caso de vasilhas abertas, os motivos principais eram confeccionados a partir de linhas escuras (vermelho) preenchidas com pequenos pontos muito escuros (preto ou vermelho escuro). É possível notar aqui a intenção da ceramista em usar a linha contínua como guia, sendo a linha pontilhada aquela que formaria o desenho (Figura 28). No caso das vasilhas fechadas, os motivos são confeccionados em cores escuras (vermelho), enquanto as cores muito escuras (preto) estavam presentes pontualmente em junções de linhas e/ou cantos (Figura 27). 


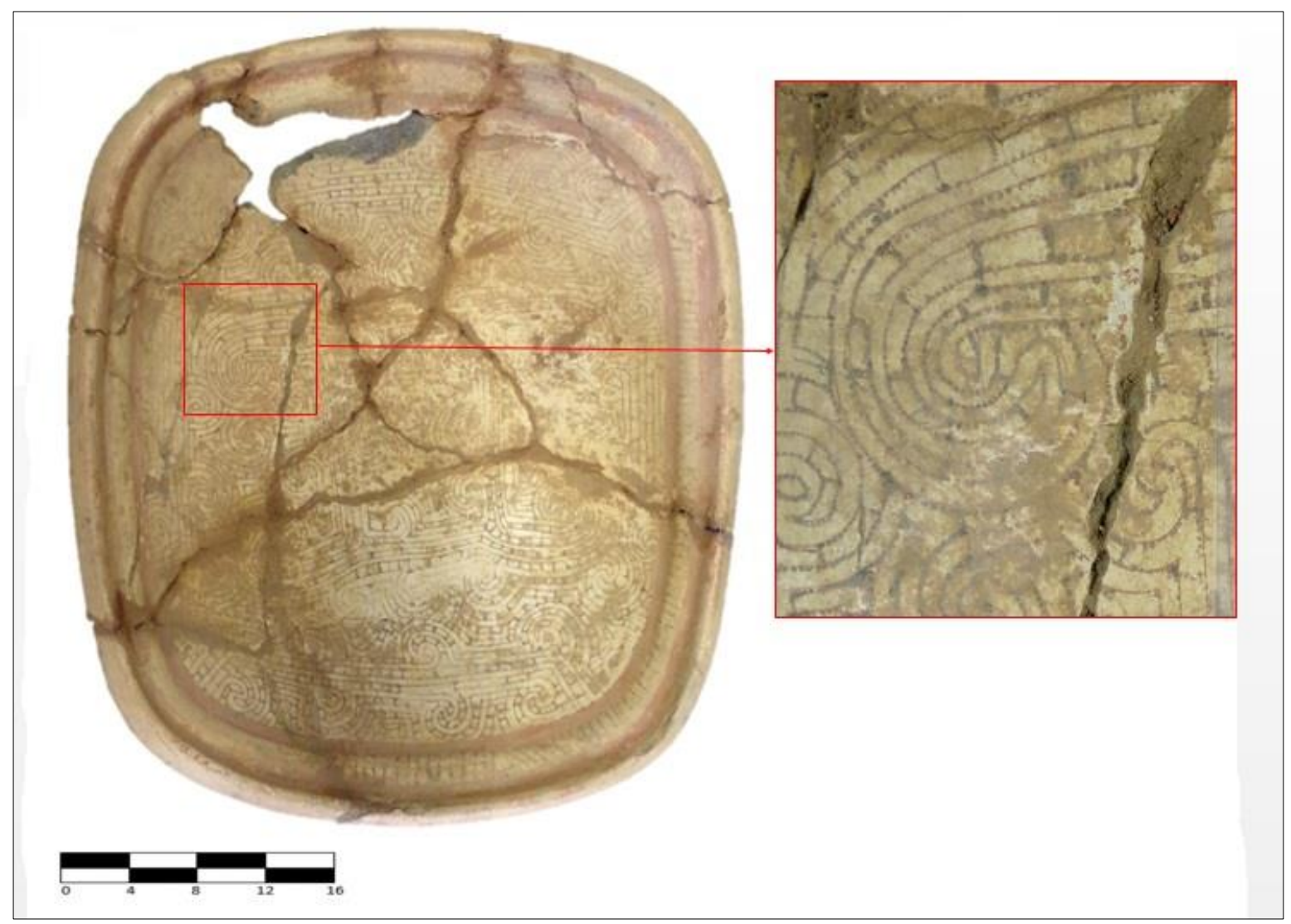

Figura 28: Vasilha aberta com motivo no campo primário confeccionados em linhas contínuas escuras sobrepostas por linhas pontilhadas muito escuras (MHS 03)

Estes motivos são aplicados sobre uma superfície preparada com uma camada de argila (engobo) de "cor muito clara", frequentemente branca. As vasilhas foco deste estudo não são diferentes, quase todas apresentaram engobo branco, com a exceção de uma única vasilha (CEMAARQ 05) que apresentou engobo vermelho (Figura 29).

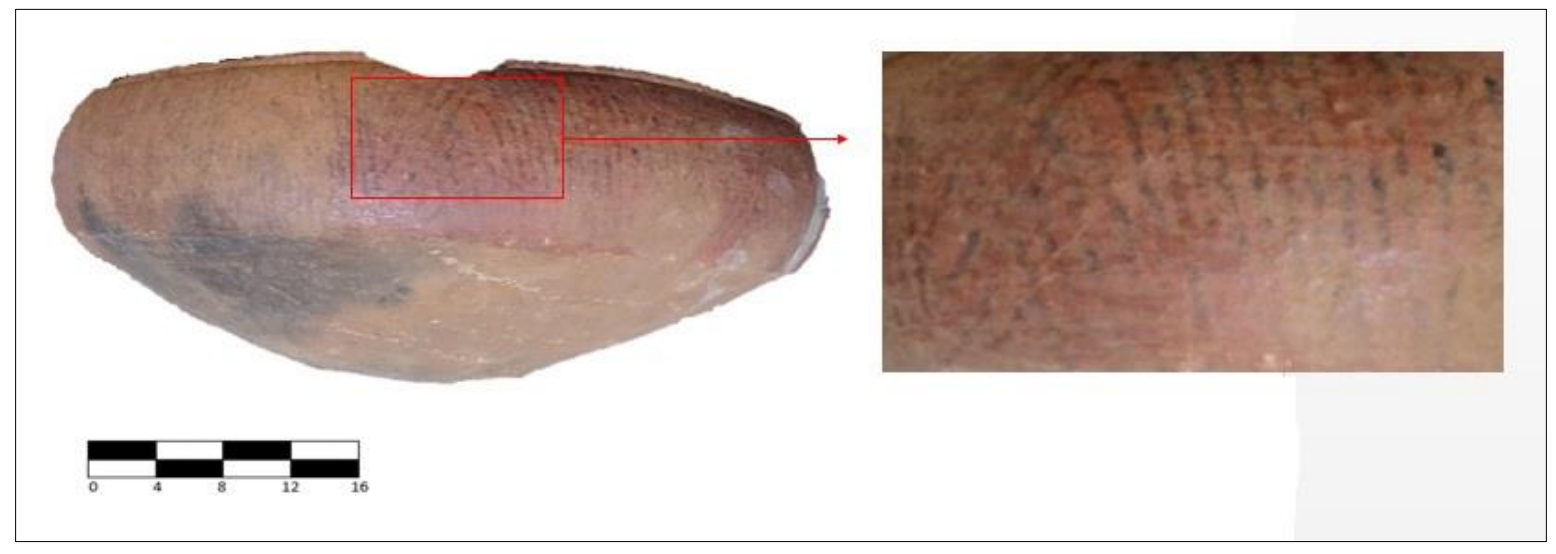

Figura 29: Vasilha com motivos pintados sobre engobo vermelho (CEMAARQ 05)

Vale ressaltar que não realizei neste estudo análises químicas que permitissem a identificação de elementos utilizados na produção das tintas/pigmentos destinados às pinturas em cerâmica. No entanto, alguns 
estudos arqueológicos (GODOY, 1946; APPOLONI et al., 1997; JÁCOME, 2006; PROUS, 2009), etnográficos (MÜLLER, 1992) e etnoarqueológicos (SILVA, 2001) afirmam que os pigmentos destinados à pintura de vasilhames são extraídos de elementos minerais, entre eles algumas variedades de óxidos de ferro para a produção de cores que variam de amarelo o vermelho e caulin para a produção de cores muito claras, como o branco (GODOY, 1946).

No que compete à composição dos grafismos, muitos autores registram e descrevem à sua maneira os motivos que identificam nas cerâmicas. No entanto, como afirmam Marois et al. (1994), quase sempre as descrições de decorações assumem padrões regionais e dificultam estudos comparativos a nível nacional. Neste sentido, optei por analisar atributos decorativos de acordo com a proposta terminológica proposta pelos autores.

Me dediquei especialmente a observação de dois atributos: gênero e categoria.

O gênero pode ser classificado como simples ou composto, considerando a composição dos elementos que fazem parte do motivo gráfico. Uma pintura simples é caracterizada por um conjunto de elementos iguais, ou seja, que seguem o mesmo sentido e movimento. Uma pintura composta, por outro lado, é caracterizada por um conjunto de elementos diversos, que seguem sentidos e movimentos diversos.

Nas vasilhas que analisei, quase todas apresentaram motivos compostos no campo primário, com exceção de um único indivíduo (MAR 04) que apresentou motivo simples (Figura 30), formado por pontos muito escuros localizados junto às faixas que delimitam o campo gráfico.

No campo secundário, a ocorrência por motivos simples foi maior (16 vasilhas), no entanto, a presença de motivos compostos ainda se mostrou mais expressiva (21 vasilhas), como é evidenciado no Gráfico 14. 


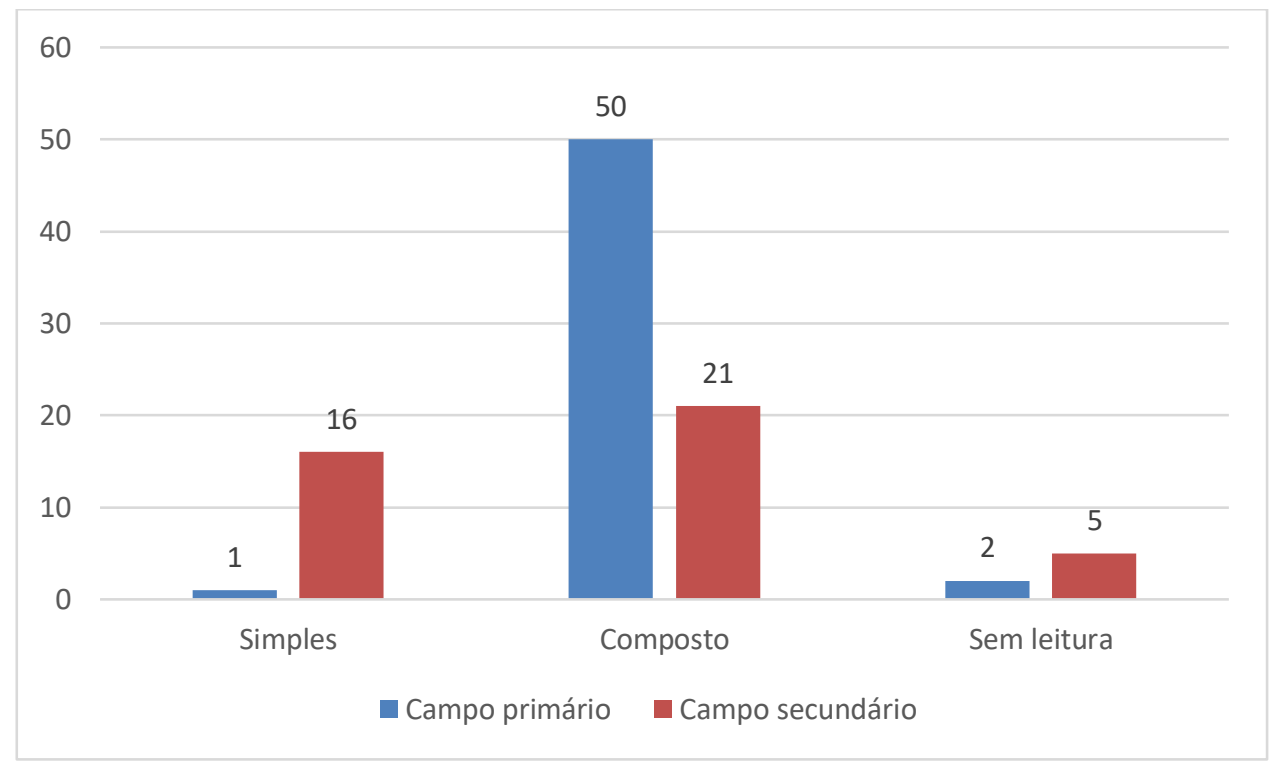

Gráfico 14: Gênero dos motivos

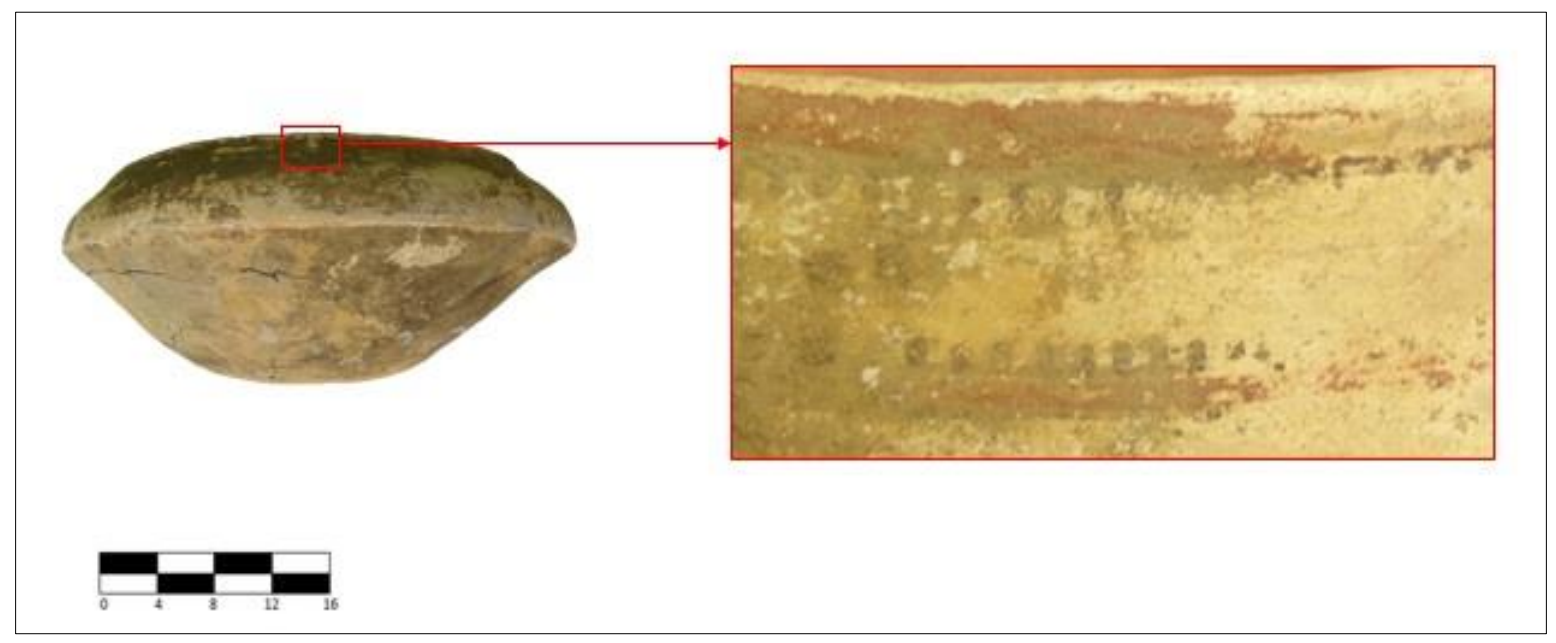

Figura 30: Vasilha com motivos simples (MAR 04)

Com relação à categoria existem três possibilidades de classificação: retilíneo, curvilíneo e pontilhado. Estas podem aparecer de maneira isolada ou associadas entre si. Uma única peça (MAR 04, Figura 30) apresentou motivo caracterizado somente como pontilhado, as demais apresentavam a combinação de traços, como fica evidente no Gráfico 15. 


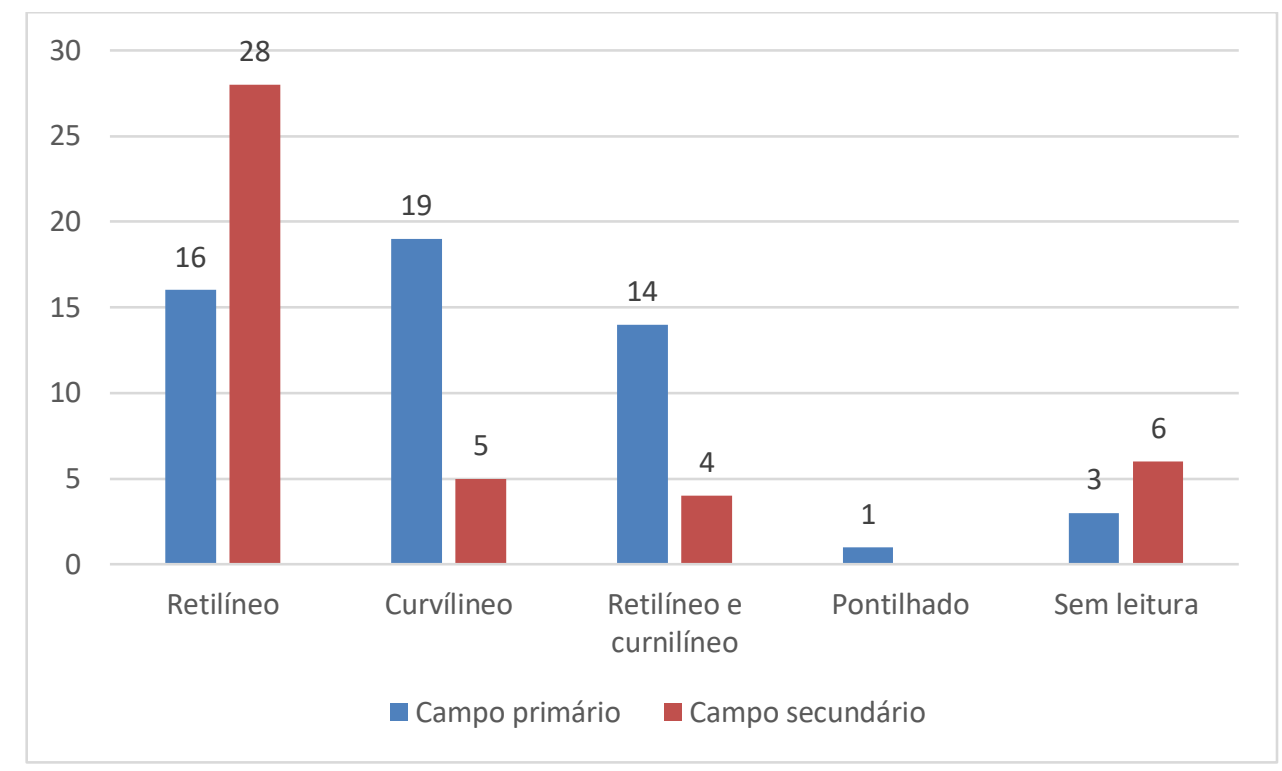

Gráfico 15: Categoria dos motivos

Os campos primários apresentam distribuição equivalente de motivos, retilíneos, curvilíneos e combinados. Estes podem costumam se formados por motivos mais complexos, sendo mais comuns motivos retilíneos e retilíneos/curvilíneos para vasilhas restritas e motivos curvilíneos para vasilhas abertas. Os campos secundários, por outro lado, apresentam maioria expressiva de motivos retilíneos de composição mais simples, frequentemente formada por linhas retas oblíquas e/ou verticais que se repetem por todo 0 campo.

Vale ressaltar que, não raro, é possível identificar no conjunto decorativo ${ }^{41}$ a formação de unidades figurativas que podem estar associadas a representações de elementos e/ou personagens do universo cosmológicos de seus grupos produtores.

\subsection{Estilos Regionais (?)}

É consenso na bibliografia arqueológica, bem como nos relatos etnohistóricos, a semelhança comportamental entre os diversos grupos Tupi, sobretudo no que diz respeito à produção tecnológica (NOELLI, 1993). Neste contexto, a indústria cerâmica destes povos se destaca pelos traços decorativos, sejam eles cromáticos ou plásticos, que se perpetuam no espaço e no tempo.

\footnotetext{
${ }^{41}$ Entendo por conjunto decorativo a junção de todos os elementos que compõem a decoração, ou seja, a decoração como um todo, incluindo os campos primário e secundário.
} 
"Por dois ângulos os Tupi-Guarani derrubam qualquer ideia de mudanças rápidas nos diversos níveis da cultura. Pelo ângulo arqueológico constata-se, com uma profundidade temporal que deve ultrapassar em muito os 3.000 anos (BROCHADO, 1984), que houve uma uniformidade na produção das vasilhas cerâmicas e nos implementos líticos" (NOELLI, 1993: 4).

Embora as semelhanças sejam marcantes no que se refere às escolhas tecnológicas para a confecção das vasilhas e de sua decoração, parto do pressuposto, como aponta Moraes (2007) e Oliveira (2008), de que a produção oleira apresenta particularidades regionais, o que pode ser percebido principalmente em seus aspectos decorativos, ou seja, na pintura. Estas particularidades podem ser consideradas estilos regionais, ou micro estilos que podem ser indicadores de representatividade étnica dentro de povos da mesma matriz cultural. Assim, embora um determinado grupo perpetue suas origens na produção oleira a partir de padrões normativos, arqueologicamente reconhecemos como tradição Tupiguarani, é possível notar especificidades nos traços e composição dos grafismos em um nível regional.

Neste sentido, me proponho a identificar semelhanças existentes nos traços, composição dos motivos e cores utilizadas pelas artesãs do passado como um conjunto de elementos característicos (e por que não, representativos) de um grupo.

Para realizar análise estilística dos motivos gráficos das vasilhas, selecionei aquelas que apresentavam motivos bem preservados, em que fosse possível identificar padrões gráficos. Estes motivos foram registrados em fotografias e decalques, conforme indicado no Capítulo 3. Optei por dividi-los em duas categorias: motivos externos e motivos internos.

\section{Motivos Externos}

No que compete aos motivos externos, identifiquei quatro grupos, os quais denominei de $A, B, C$ e $D$ (PRANCHA 05).

Os motivos do Grupo A podem ser caracterizados primeiramente pela utilização de duas cores: uma escura, representada nos desenhos pelo vermelho, e outra muito escura, representada nos desenhos pelo preto. A cor escura é utilizada na aplicação de múltiplas linhas retas e curvas que formam ganchos ou semicírculos concêntricos que se repetem horizontalmente. A cor 
muito escura, por sua vez, aparece de maneira pontual, reforçando a junção de linhas ou ainda de forma contínua ao longo das linhas. O campo secundário deste grupo pode ser caracterizado por linhas retas oblíquas à direita e esquerda que se unem de maneira alternada, ora na parte superior do campo, ora na parte inferior, formando uma espécie de triângulo, ou seja, trata-se de um conjunto decorativo composto, com motivos diferentes no campo primário e secundário (LA SALVIA \& BROCHADO, 1989). Também identifiquei uma vasilha cujo conjunto decorativo é do tipo simples, ou seja, o mesmo motivo se repete em dois campos gráficos. Interessante notar que este padrão está presente majoritariamente em vasilhas cambuchuí, mas aparece em uma vasilha do tipo cambuchí caguâba.

O Grupo B pode ser caracterizado principalmente por motivos em linhas muito escuras aplicados apenas em vasilhas do tipo cambuchí caguâba, todas elas com apenas um campo gráfico, composto por linhas oblíquas à direita e à esquerda que se unem de maneira alternada na parte superior e inferior do campo, formando triângulos que se repetem no sentido horizontal. Há também uma vasilha que apresentou linhas oblíquas e verticais, estas últimas apareciam em quantidade reduzida (apenas 3 linhas) e marcavam 0 início e/ou fim de uma sequência de linhas oblíquas a direita. É interessante notar neste grupo a presença do engobo vermelho em todas as vasilhas: duas delas apresenta engobo na parte inferior ao ombro, ou seja, abaixo dos motivos e uma delas recebe a pintura sobre o engobo vermelho.

Os motivos do Grupo $\mathbf{C}$ podem ser caracterizados por múltiplas linhas em cor escura, representada nos decalques pelo vermelho, com pequenas ondulações, que por sua vez, formam motivos sinuosos que se organizam de maneira concêntrica. Este padrão esteve presente apenas em vasilhas do tipo cambuchí.

Os motivos do Grupo D podem ser caracterizados pela composição em linhas simples ou duplas nos sentidos vertical e horizontal formando motivos geométricos que se repetem horizontalmente, podendo haver uma ou mais fileiras de motivos. Os motivos deste grupo estão presentes em vasilhas do tipo cambuchí e cambuchí caguâba. 


\section{PRANCHA 05}

\section{Motivos Externos}

A
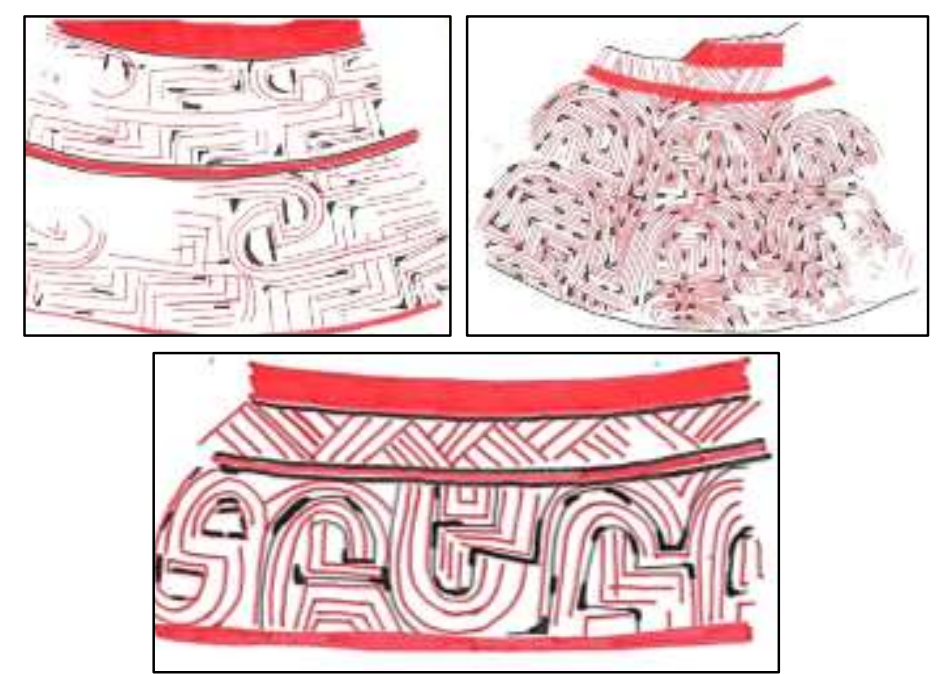

D
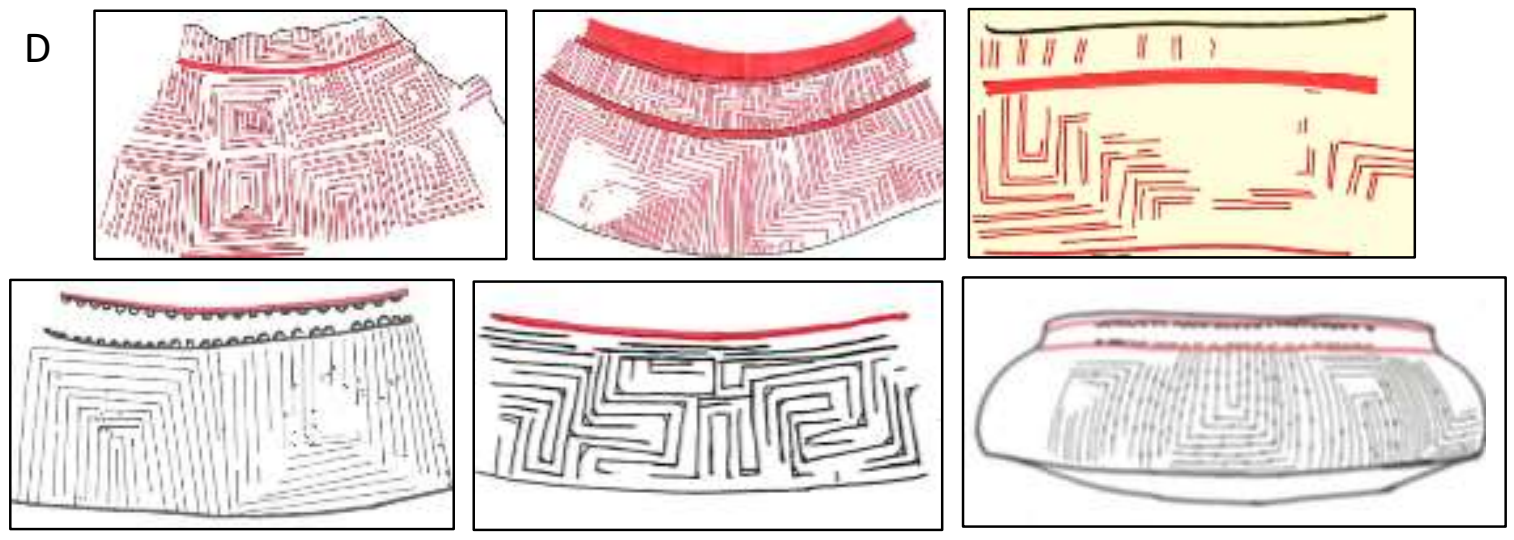

* As imagens são meramente ilustrativas e estão fora de escala
B
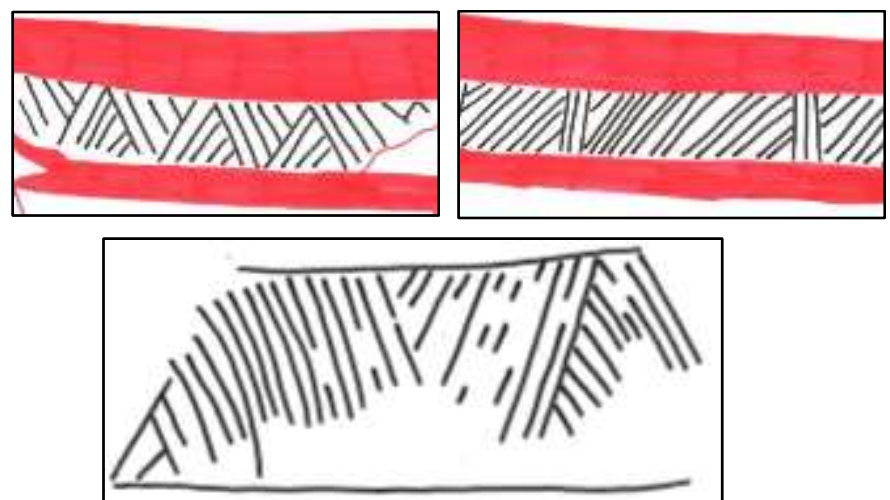

C

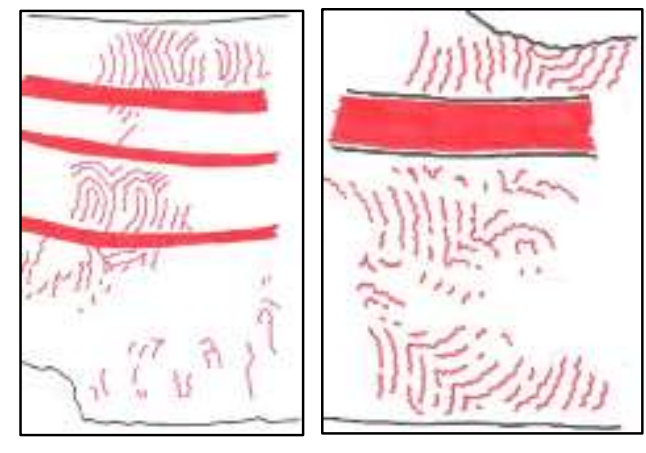

Dissertaç̧̃o de Mestrado: A'ANGA ETE MA - IMAGENS VERDADEIRAS DO PASSADO: um estudo sobre a ceramica Iupi pintada do interior paulista

$M A E[S]$ 
Dando sequência aos padrões gráficos, identifiquei nos campos internos outros quatro grupos, os quais denominei E, F, G (Prancha 06).

Os motivos do Grupo E podem ser caracterizados principalmente pela composição concêntrica presente no campo primário. Neste sentido, a oposição centro/periferia é ainda mais evidente, pois há um motivo principal na porção central que orienta toda a composição do desenho preenchido no sentido periférico. Os motivos são compostos por múltiplas linhas paralelas que dobram sobre si mesmas, formando desenhos sinuosos que lembram a forma de um ser (humano ou não), conforme apresentarei no tópico seguinte. O espaço entre as linhas paralelas é preenchido alternadamente por pequenos traços pontilhados. Os motivos presentes nos campos secundários apresentam linhas retas oblíquas à direita e à esquerda, formando triângulos.

É interessante notar que duas vasilhas deste grupo apresentam o mesmo motivo, sendo uma vasilha grande (FCJ $04-53 \mathrm{~cm}$ de borda) e uma vasilha pequena ( $F C J 02-23 \mathrm{~cm}$ de borda). As duas são acervo da $F C J$ e foram resgatas em um mesmo contexto funerário no município de Canas (SP), no âmbito do projeto "Salvamento Arqueológico Sítio Caninhas" desenvolvido em 2002 (Figura 31). 


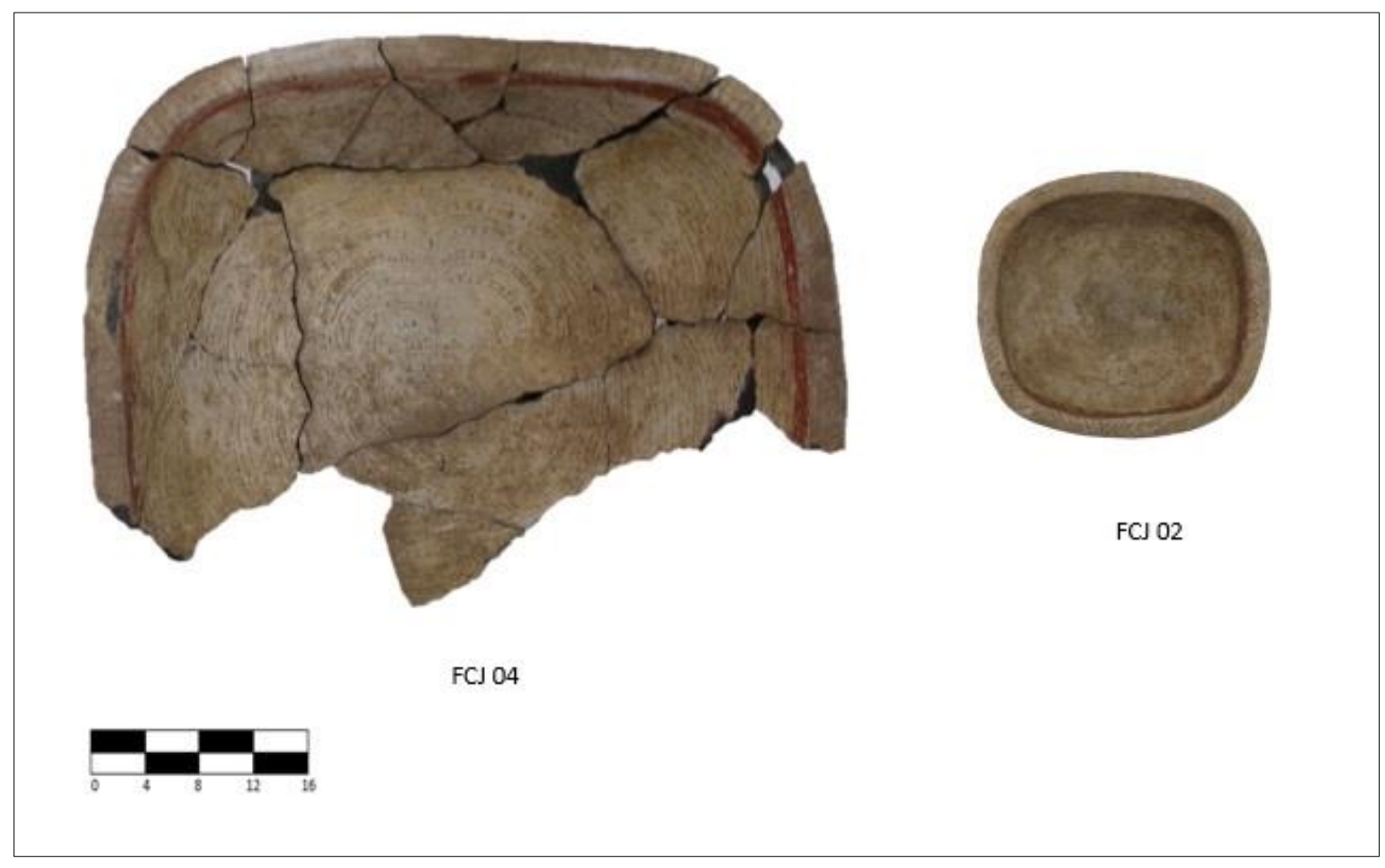

Figura 31: Vasilhas de dimensões diferentes apresentam o mesmo padrão (FCJ 04, FCJ 02)

Também chamo a atenção para a vasilha acervo do MHS (MHS 03) que apresenta um padrão gráfico semelhante às demais unidades deste grupo, porém, as linhas contínuas paralelas que formam o motivo são sobrepostas por linhas pontilhadas ao longo de toda a decoração, diferente das demais, onde as linhas pontilhadas apenas preenchem os espaços entre as linhas.

Os motivos do Grupo F podem ser caracterizados pela utilização de duas cores, uma escura (representada pelo vermelho) e outra muito escura (representado pelo preto). Assim como os motivos do Grupo A presentes em superfícies externas, os motivos do Grupo F também são confeccionados em linhas retas e curvas formando ganchos e/ou semicírculos, estas linhas são reforçadas com traços muito escuros.

Duas vasilhas deste grupo apresentam o mesmo padrão gráfico no campo secundário, formado predominantemente por múltiplas linhas onduladas nas paredes internas da vasilha.

As bandas que delimitam os campos gráficos são bem finas (com largura inferior a $0,5 \mathrm{~cm}$ ) e são reforçadas por linhas muito escuras.

Os motivos do Grupo G podem ser caracterizados por motivos em cores muito escuras, compostos segmentos de linhas curvas preenchidas por pequenos pontos. Os conjuntos decorativos deste grupo se diferenciam dos 
demais motivos localizados na face interna por se organizar de maneira linear. Este tipo de distribuição dos motivos em vasilhas abertas com pintura interna é menos frequente, pois devido à morfologia do vasilhame o observador não é capaz de identificar a orientação do conjunto decorativo, ou seja, um motivo pode ser observado por diversos ângulos. Neste sentido, a única "lógica" que parece estar presente em vasilhas neste formato seria a relação centro/periferia, a mesma lógica que orienta a localização dos campos primários e secundários. 
Brochado (1984) aponta para dois grandes conjuntos cerâmicos vinculados às populações Tupi, são eles: Guarani e Tupinambá. Tal separação, segundo o autor, está centrada nos seguintes atributos: forma, técnicas de acabamento de superfície, localização da decoração na vasilha e categoria funcional das vasilhas.

No que se referem às pinturas, as vasilhas Guarani e Tupinambá apresentam muitas semelhanças: ambas são marcadas pela policromia e pela presença de campos decorativos com estruturas semelhantes, seguindo as mesmas regras gerais, sendo comuns os motivos geométricos. No entanto, segundo Prous (2011), a pintura da cerâmica Tupinambá é marcada pela predominância de motivos curvilíneos que seguem uma minuciosa simetria, tais como àqueles dos Grupos A. E, F e G.

A pintura Guarani, por outro lado, seria marcada pela predominância de traços retilíneos, tais como os motivos dos Grupos B, C e D.

$\mathrm{Na}$ Prancha 07 apresento um mapa coma distribuição espacial dos motivos gráficos que pude identificar com mais clareza nas vasilhas, estes já apresentados nas Pranchas 05 e 06. 


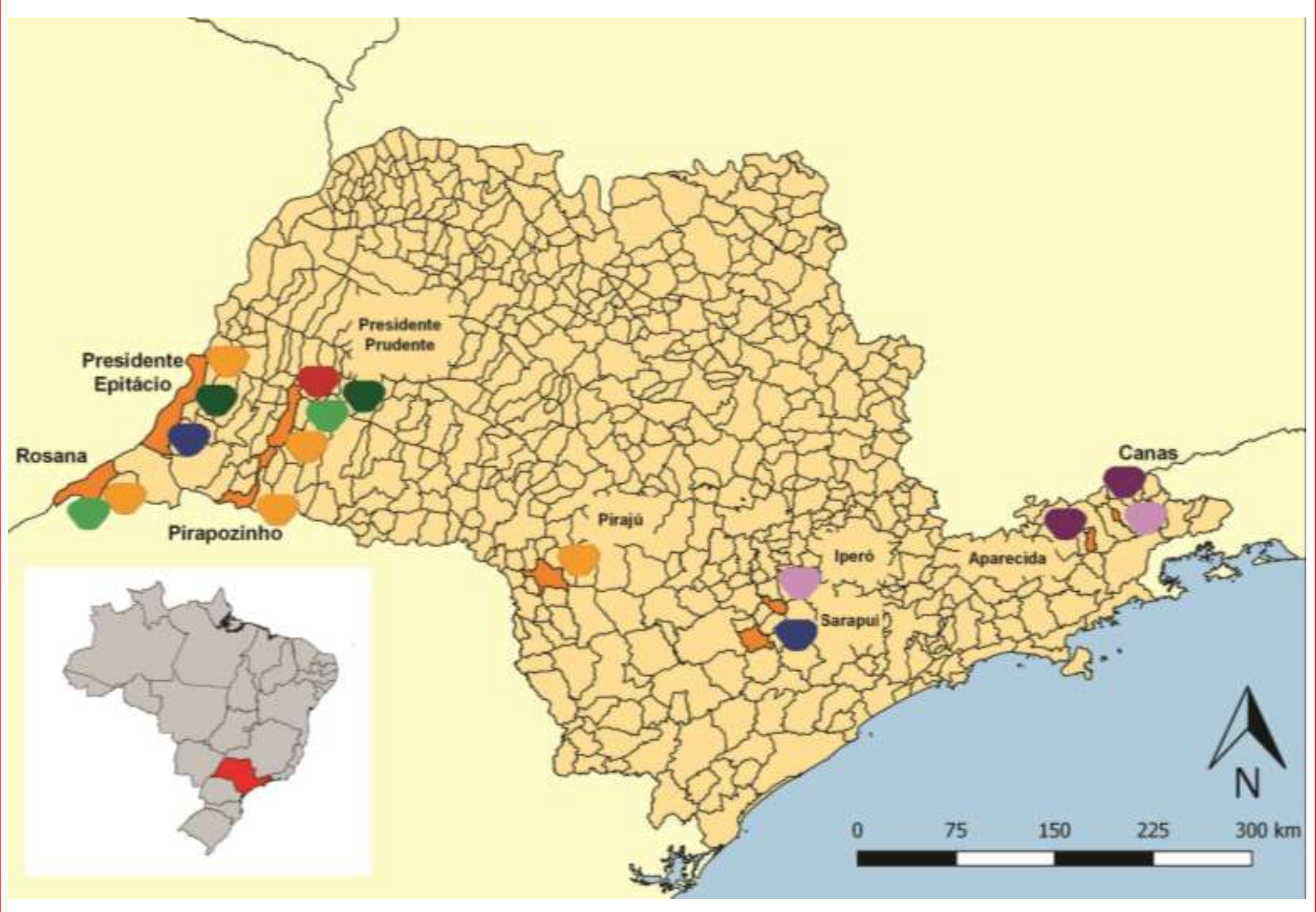

\section{PRANCHA 07}

Distribuição espacial

dos motivos gráficos

\section{LEGENDA:}

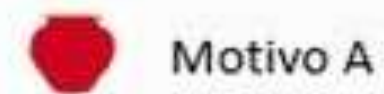

CMotivo B

Motivo C

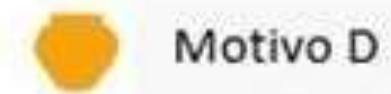

\section{Dotivo E}

b Motivo F

B Motivo $G$

Dissertaçäo de Mestrado: A'ANGA ETE MA - IMAGENS VERDADEIRAS DO PASSADO: um estudo sobre a cerâmica Tupi pintada do interior paulista". 
No mapa é possível notar três concentrações de material, a primeira na região do Pontal do Paranapanema (PP) e Alto Paranapanema (ALPA), a segunda na região do Vale do Paraíba e a terceira na região de do Tietê/Sorocaba.

A porção oeste do estado apresenta maior concentração de estilos gráficos (e é também a região onde analisei a maior quantidade de indivíduos). Nesta região identifiquei vasilhas com os motivos dos tipos $A, B, C, D$ e $E$ distribuídos conforme a Tabela 2.

\begin{tabular}{|c|c|c|}
\hline $\begin{array}{c}\text { Proveniência } \\
\text { (Município) }\end{array}$ & $\begin{array}{c}\text { Tipo de } \\
\text { Grafismo }\end{array}$ & $\begin{array}{c}\text { Quantidade } \\
\text { de vasilhas }\end{array}$ \\
\hline \multirow{3}{*}{$\begin{array}{c}\text { Presidente } \\
\text { Prudente }\end{array}$} & $\mathrm{A}$ & 3 \\
\cline { 2 - 3 } & $\mathrm{C}$ & 2 \\
\cline { 2 - 3 } & $\mathrm{D}$ & 1 \\
\cline { 2 - 3 } & $\mathrm{F}$ & 1 \\
\hline \multirow{2}{*}{$\begin{array}{c}\text { Presidente } \\
\text { Epitácio }\end{array}$} & $\mathrm{F}$ & 1 \\
\cline { 2 - 3 } & $\mathrm{B}$ & 1 \\
\cline { 2 - 3 } & $\mathrm{D}$ & 1 \\
\hline \multirow{2}{*}{ Rosana } & $\mathrm{C}$ & 2 \\
\cline { 2 - 3 } & $\mathrm{D}$ & 1 \\
\hline Pirapozinho & $\mathrm{D}$ & 1 \\
\hline Piraju & $\mathrm{D}$ & 1 \\
\hline
\end{tabular}

Tabela 2: Distribuição dos padrões gráficos na região do Pontal do Paranapanema

Esta região pode ser marcada pela predominância de vasilhas com motivos externos do tipo cambuchí e cambuchí caguãba. Apenas duas vasilhas (CEMAARQ 13 e CEMAARQ 14) apresentaram motivos internos (motivo do Grupo F).

A segunda concentração de material está na região do Vale do Paraíba, mais especificamente nos municípios de Canas e Aparecida. Nesta região identifiquei apenas duas classes de motivos: Grupos $\mathrm{F} \mathrm{e} \mathrm{H}$, ambos localizados na face interna, ou seja, em vasilhas abertas (Tabela 3). 


\begin{tabular}{|c|c|c|}
\hline $\begin{array}{c}\text { Proveniêia } \\
\text { (Município) }\end{array}$ & $\begin{array}{c}\text { Tipo de } \\
\text { Grafismo }\end{array}$ & $\begin{array}{c}\text { Quantidade } \\
\text { de vasilhas }\end{array}$ \\
\hline \multirow{2}{*}{ Canas } & E & 3 \\
\cline { 2 - 3 } & G & 2 \\
\hline Aparecida & G & 1 \\
\hline
\end{tabular}

Tabela 3: Distribuição dos padrões gráficos Vale do Paraíba

A terceira concentração está localizada na região de Sorocaba, mais especificamente nos municípios de Iperó e Sarapuí, onde identifiquei vasilhas com motivos dos grupos B e F, sendo duas vasilhas do tipo cambuchí caguãba com pintura externa e uma vasilha do tipo ñaembé / teembirúcom pintura interna.

\begin{tabular}{|c|c|c|}
\hline $\begin{array}{c}\text { Proveniência } \\
\text { (Município) }\end{array}$ & $\begin{array}{c}\text { Tipo de } \\
\text { Grafismo }\end{array}$ & $\begin{array}{c}\text { Quantidade } \\
\text { de vasilhas }\end{array}$ \\
\hline Sarapui & $\mathrm{B}$ & 2 \\
\hline Iperó & $\mathrm{E}$ & 1 \\
\hline
\end{tabular}

Tabela 4: Distribuição dos padrões gráficos Tietê/Sorocaba

A distribuição dos padrões gráficos reforça os dados apresentados por Correa (2014) com base no modelo de dispersão dos povos Tupi de Brochado (1984). A região entre Paranapanema e Tietê, mais especificamente na margem esquerda, consistem em um ponto de encontro entre as populações produtoras das cerâmicas Guarani e Tupinambá.

Já a região do Vale do Paraíba estaria associada ao conjunto Tupinambá, com predominância de vasilhas abertas e pinturas interna formadas por motivos curvilíneos.

\title{
4.2 Produção cerâmica: arte, comunicação e representação
}

\begin{abstract}
"Símbolos serpentinos, triângulos, animais como a rã, a coruja, a onça, o gavião; símbolos do feminino, da gravidez, da abundância, da prosperidade; assim como símbolos do masculino, do sol, da flecha, da lança, da ação, estão presentes como códigos universais em todos os materiais achados em sítios arqueológicos. Na verdade, são fragmentos registrados da produção dos primeiros tempos após o final do primeiro ciclo de Tupã" (JECUPÉ, 1998: 41).
\end{abstract}

Segundo Rice (1987), uma abordagem iconográfica sobre a arte, consiste em ultrapassar as questões sociais que envolvem as preferências estéticas na confecção de um objeto e buscar compreender seu significado, entendendo-o 
como um código simbólico que reforça as estruturas cosmológicas de um determinado grupo.

Neste estudo parto do pressuposto de que as vasilhas pintadas, bem como os demais objetos produzidos por grupos indígenas, não foram produzidas com uma finalidade meramente estética, mas sim para servir a determinado fim prático (VIDAL e SILVA, 1992; OLIVEIRA, 2008; SCHAN, 1997). Neste sentido, entre as sociedades indígenas, o que muitas vezes chamamos de arte/decoração (sobretudo a produção gráfica), pode ser entendido como um sistema de comunicação visual (PROUS, 2005, 2009, 2011; OLIVEIRA, 2008; TOCHETTO, 1996; LA SALVIA \& BROCHADO, 1989; SCHAN, 1997; VIDAL, 1992).

A pintura na cerâmica Tupi pode ser considerada um importante instrumento de comunicação social no qual a ceramista, tendo um corpo limitado de opções (pois seguem os mesmos padrões e/ou estruturas, de forma consciente ou não), cria sempre novos motivos a partir dos quais consegue se comunicar, com os demais membros do grupo. Contudo, como lembra Geertz (1997), a comunicação só se completa entre indivíduos que compartilham o mesmo sistema simbólico, uma vez que estes são formados culturalmente a partir de experiências individuais que envolvem, entre outros aspectos, as relações de ensino e aprendizagem.

Ainda que os grafismos tenham sido criados para comunicação interna, Vidal (1992) defende seu papel como indicadores de etnicidade, ou seja, a existência de um conjunto de características recorrentes, como as cores e a delimitação dos campos gráficos com limites gráficos (bandas) e físicos (bordas ombros), fariam referência ao grupo produtor (não ao indivíduo), comunicando ao "outro" sua identidade étnica.

Desvendar o(s) significado(s) deste sistema simbólico tão marcante na produção oleira de grupos indígenas de matriz cultural Tupi consiste em um desafio para os(as) arqueólogos(as), uma vez que o contato direto com as produtoras/artesãs é impossível devido à distância temporal. Diante disso, a arte gráfica presente no contexto arqueológico acaba, muitas vezes, sendo rotulada como abstrata, ou simplesmente descrita como geométrica (OLIVEIRA, 2008), ficando em segundo plano seu real papel social. 
Para contornar este problema, duas abordagens teórico-metodológicas podem colaborar para uma interpretação mais minuciosa sobre a arte gráfica em contextos arqueológicos, a saber: semiótica e a antropologia da arte.

A primeira delas consiste em compreender a arte gráfica de modo estrutural, isolando motivos mínimos que se combinam de formas diversas, formando um sistema de comunicação não-verbal. Neste contexto, os motivos são entendidos como signos e/ou símbolos, ou seja, um elemento dotado de significado para alguém em algum lugar (PEIRCE, 2008).

A segunda é composta por diversas abordagens, entre elas a proposta de Gell (1998), na qual os objetos são percebidos como agentes sociais capazes de desencadear ações. Neste caso, é preciso conhecer o contexto em que circulam as vasilhas em foco. Com base na bibliografia arqueológica (GODOY, 1974; LA SALVIA \& BROCHADO, 1989; BROCHADO, 1984; OLIVEIRA, 2008; PROUS, 2005, 2009, 2011), antropológica (FERNANDES, 2006 [1952]; SCHADEN, 1962; VIDAL, 1992; CARVALHO, 1999; MANO, 2009) e em fontes etnohistóricas (STADEN, 2011; LÉRY, 1961; CADOGAN, 1959), é possível chegar a um leque de possibilidades interpretativas sobre os usos e funções das vasilhas aqui estudadas.

É válido ressaltar que a aproximação de contextos arqueológicos com fontes etnohistóricas e etnográficas é deveras delicada, uma vez que as sociedades indígenas vêm se reconfigurando, assumindo novas formas de organização social, narrativas míticas, produção material, etc. a partir de contato com o "outro" (indígena e não indígena) ao longo dos anos. No entanto, insisto na continuidade e dispersão das populações Tupi em quase todo o território brasileiro (bem como em parte do Paraguai, Uruguai e Argentina) já atestada por outros autores (BROCHADO, 1984; LA SALVIA E BROCHADO, 1989; NOELLI, 1993; CORREA, 2014), o que nos permite estabelecer uma relação, ainda que tímida, entre as diversas fontes bibliográficas.

Neste sentido, as imagens e textos produzidos por viajantes do passado sugerem possibilidades de usos para diversos artefatos. No caso das vasilhas cerâmicas pintadas, podemos interpretá-las como objetos rituais, utilizados em sepultamentos primários e/ou secundários em urnas (vasilhas que assumem a função primeira de preparo e armazenagem de bebidas fermentadas), em rituais 
antropofágicos, para servir as partes internas do prisioneiro, ou ainda para consumir bebidas fermentadas, como foi registrado por cronistas que mantiveram contato com grupos Tupi da costa entre os séculos $\mathrm{XV}, \mathrm{XVI}$ e XVII.

Diante do exposto, parto agora para a exposição de alguns padrões figurativos que pude identificar em algumas vasilhas que foram alvo de análise nesta dissertação.

\section{Motivos Curvilíneos}

Os motivos curvilíneos, são mais comuns em vasilhas abertas, do tipo ñaembé / teembirú.

Inspirado nas diversas imagens produzidas por cronistas e viajantes que tiveram contato com povos indígenas nos primeiros séculos de situação colonial, Prous (2011) propõe uma interpretação interessante sobre as vasilhas abertas, as quais o autor denomina "Proto-Tupi", cuja pintura interna é composta por linhas sinuosas que se dobram sobre si mesmas. Essas linhas, segundo o autor, seriam representações de partes internas do corpo humano, como as vísceras ou o cérebro, provavelmente fazendo referência às partes consumidas do indivíduo sacrificado no ritual antropofágico (Figura 32).

O autor afirma ainda que, em alguns casos, feixes de linhas sinuosas podem representar o próprio corpo humano, e identifica padrões figurativos em uma série de vasilhas, como indica a Figura 34, que sugeririam tal representação, descritos pelo autor da seguinte maneira.

\footnotetext{
"Numerosas também são figuras parecidas, porém com as duas extremidades bífidas; ou uma parte central quadrangular, de cujas quinas saem apêndices curvos. Interpretamos estas últimas como representações esquematizadas do corpo humano" (PROUS, 2009: 13, grifo meu).
} 


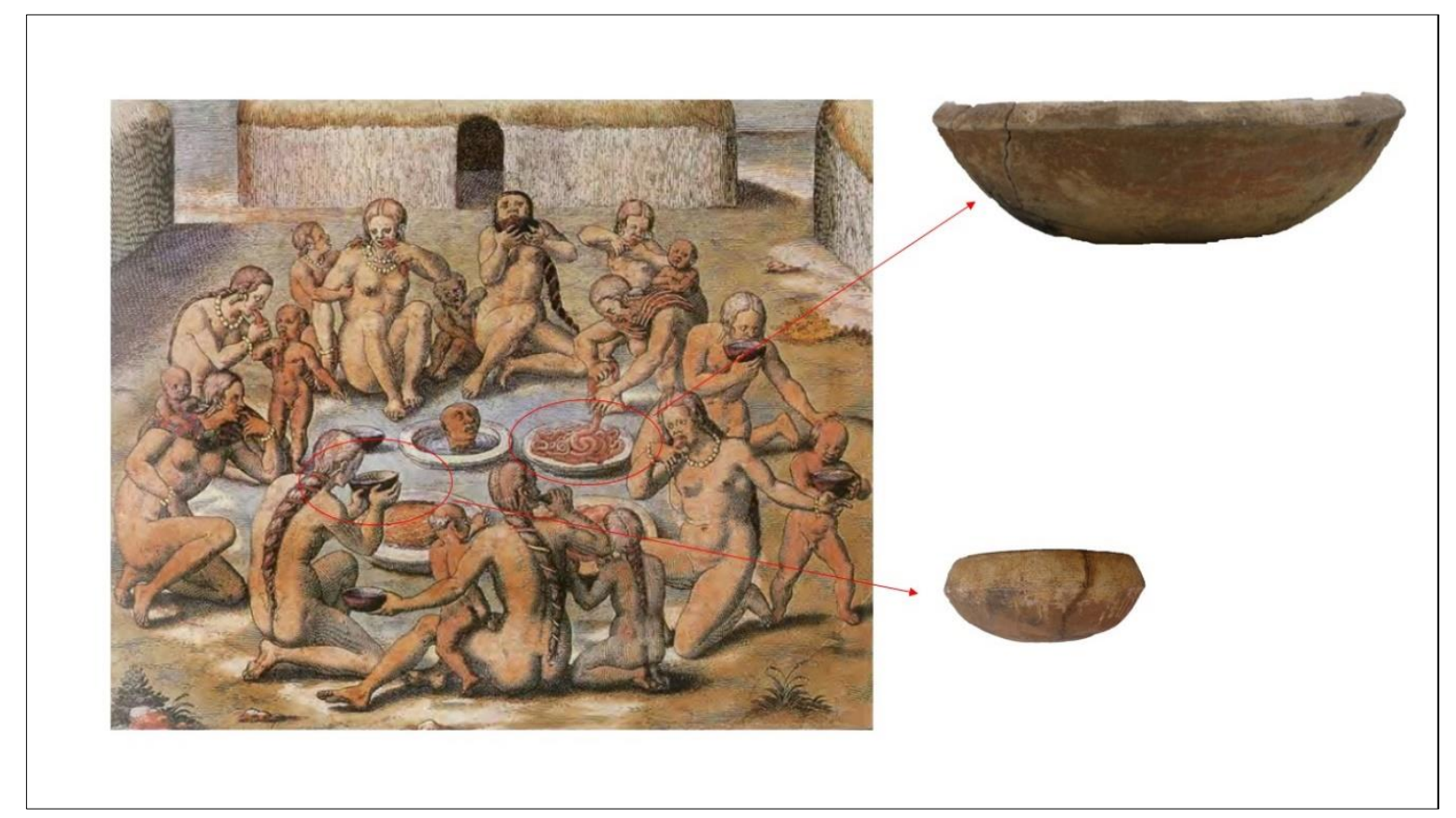

Figura 32: Imagem produzida por Theodore de Bry no século XVI, inspirado na obra e nas gravuras produzidas por Hans Staden. Na imagem vasilhas abertas recebem a cabeça e as partes internas do sacrificado. Ao mesmo tempo, vasilhas menores (provavelmente do tipo cambuchí caguâba) são utilizadas para o consumo de líquidos 


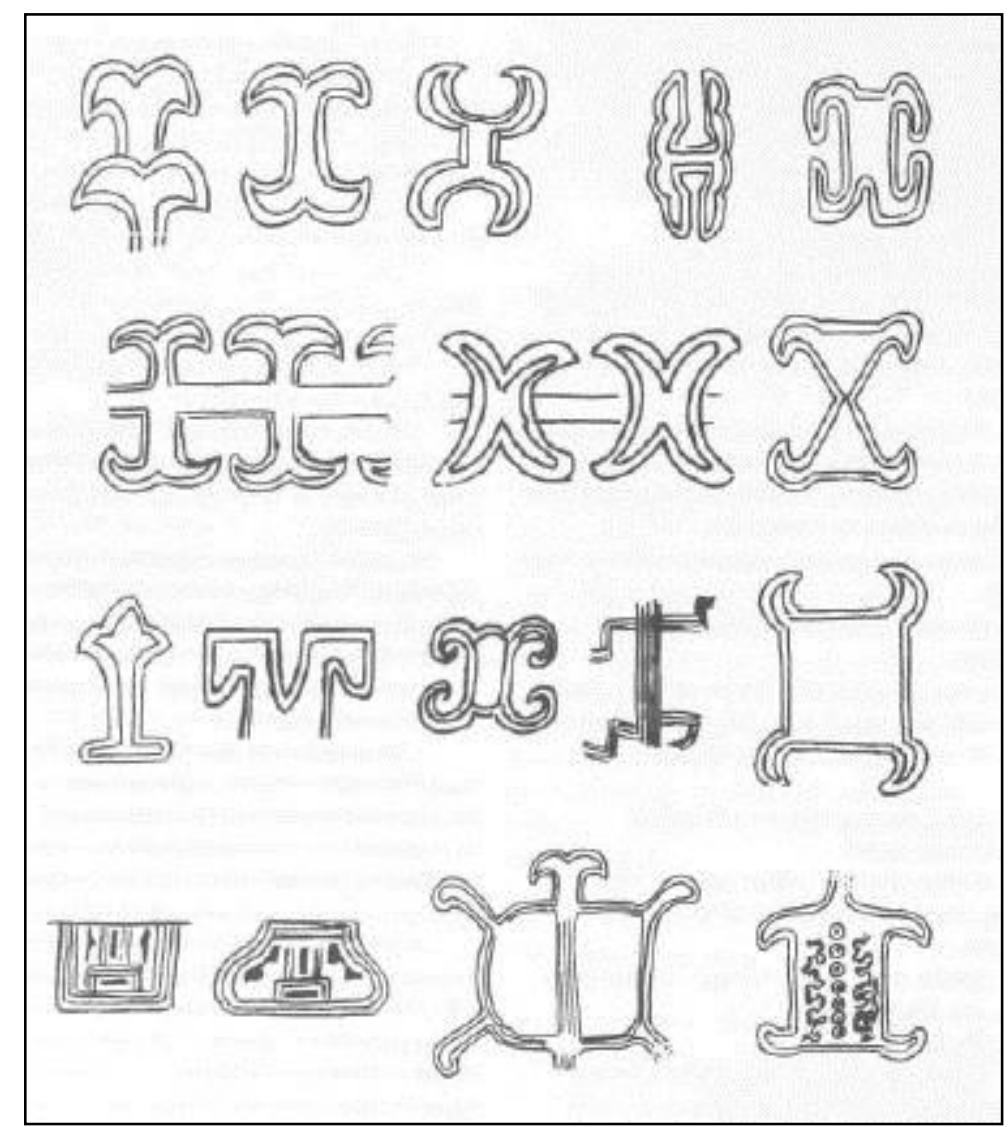

Figura 33: Possíveis representações corporais segundo Prous (2009)

Dentre as vasilhas que tive a oportunidade de analisar, três apresentaram os padrões descritos por Prous no trecho supracitado (Figura 33). Tratam-se das vasilhas pertencentes ao Grupo E (apresentados na Prancha 6), sendo duas delas acervo da FCJ, apresentando o mesmo grafismo e provenientes do mesmo contexto arqueológico (Sítio Canas), uma dentro da outra; uma terceira vasilha com estes padrões, acervo do MHS, foi identificada no município de Iperó. 


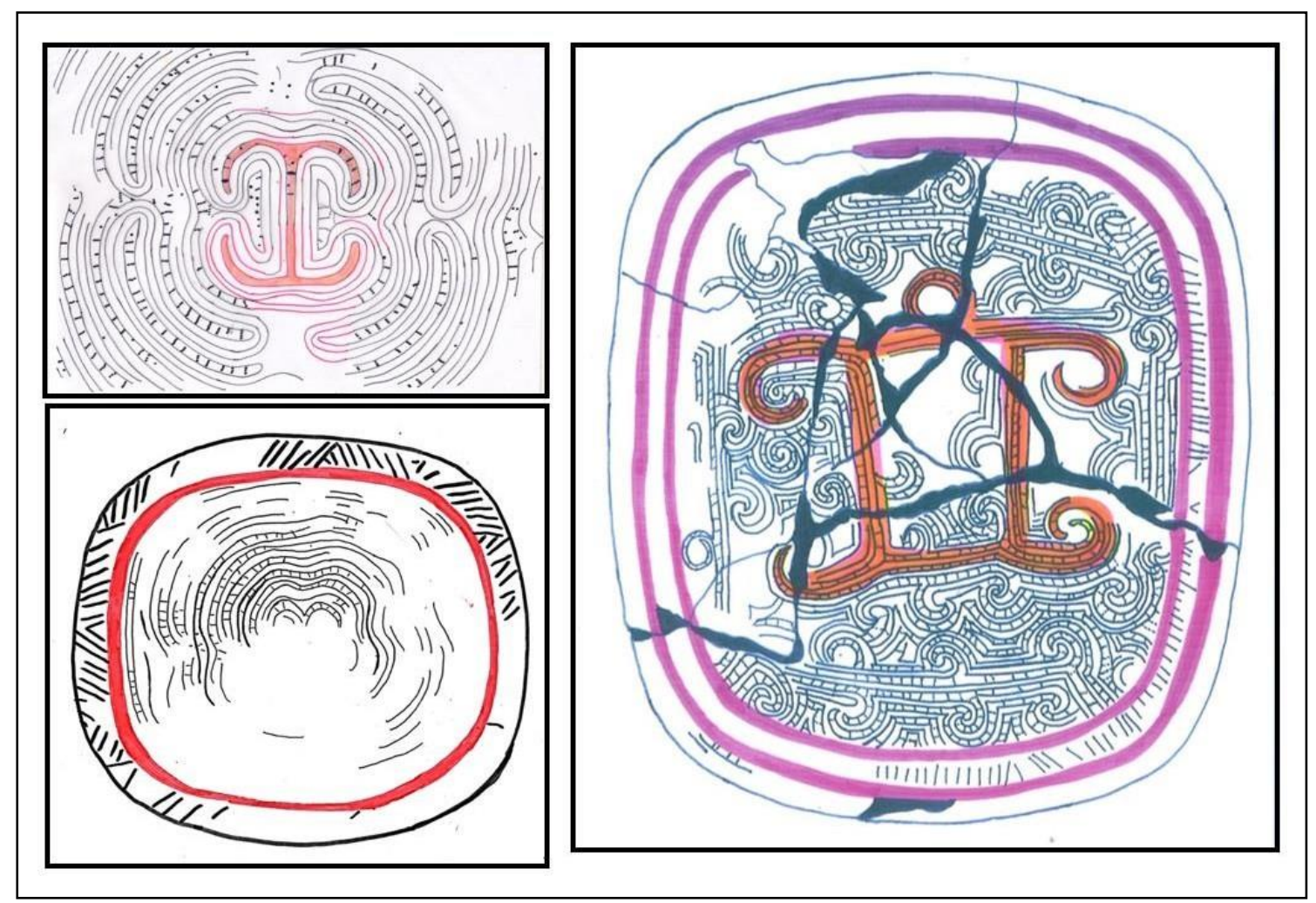

Figura 34: Vasilhas com representação humana

A Figura 34 mostra em destaque as unidades figurativas que podem ser a representação de um corpo humano. É possível notar que a parte interna está preenchida por pequenas espirais que podem fazer referência aos órgãos humanos internos ou à pintura corporal.

Interessante notar que, em ambos os casos, a representação dos membros superiores e inferiores se apresentam de forma bastante estilizada, como se fossem espirais. Padrões semelhantes foram identificados por Barreto (2008) em urnas Marajoara. Segundo a autora,

"Estas urnas [Marajoara] verdadeiramente antropomorfas se assemelham muito às formas plásticas encontradas nas urnas Guarita, com apliques laterais na forma de cobra indicando os braços, e os pés elevados como se o indivíduo estivesse sentado, com as pernas dobradas e os pés acima da base" (BARRETO, 2008: 198). 


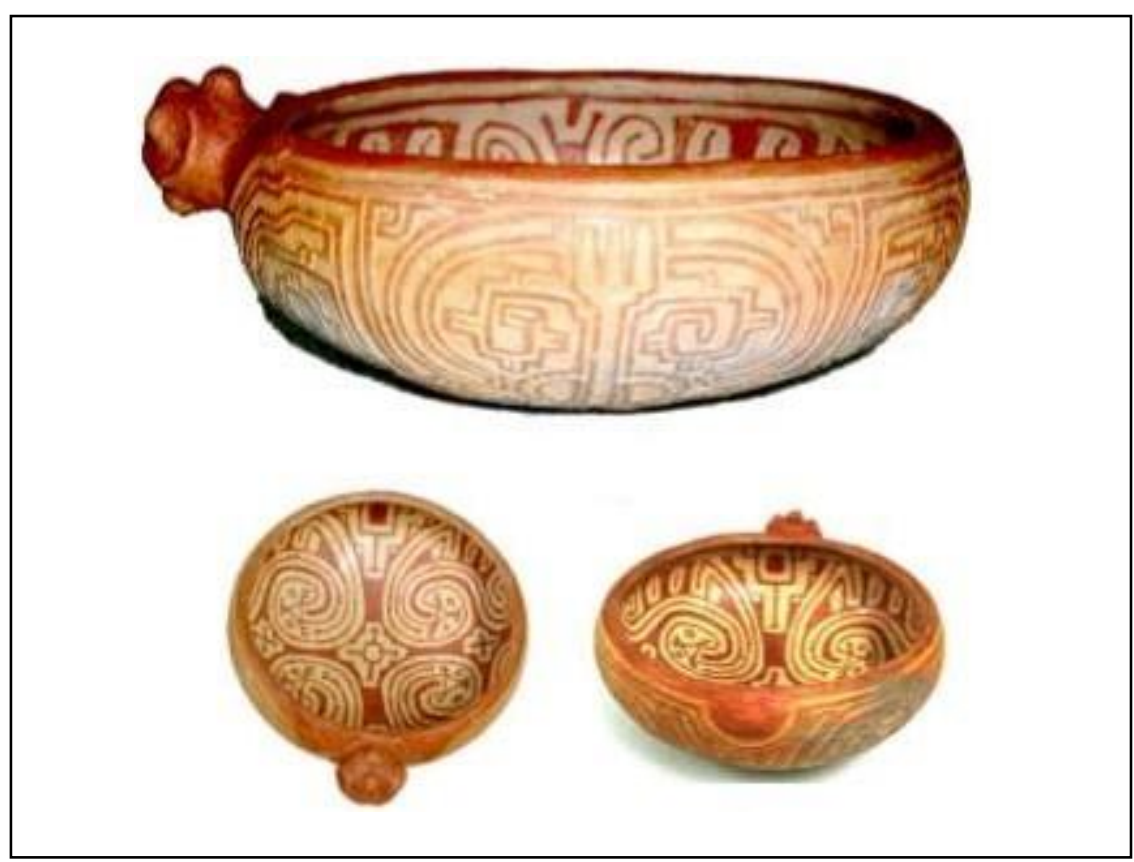

Figura 35: Vasilhacomrepresentaçõeshumanas, cujosmembrosseapresentam deformaespiralada. (BARRETO, 2008: 145)

Como sugerem as imagens e relatos produzidos por viajantes e cronistas ao longo dos primeiros três séculos de situação colonial no Brasil (STADEN, 2011; LÉRY, 1961) as vasilhas (Tupi) ornamentadas com ricos motivos gráficos eram produzidas para ocasiões específicas, entre elas aquelas que envolviam a morte, seja do inimigo (sacrifício ritual) ou de um membro do grupo.

Segundo Florestan Fernandes (2006 [1952]) entre os Tupinambá a guerra era um elemento crucial para a constante alimentação da estrutura social deste grupo, uma vez que um complexo sistema baseado na morte e na vingança era responsável pela produção de pessoas $^{42}$.Para o autor, a formação de todo indivíduo adulto do sexo masculino na sociedade Tupinambá envolvia necessariamente a guerra, a morte de membros do grupo, a captura e escravização de inimigos em busca de vingança e o ritual antropofágico. Esta cadeia de fatos seria responsável por alimentar uma complexa estrutura de relações mútuas entre os Tupinambá e seus inimigos, entre eles os Carijó e os Tupiniquim (STADEN, 2011).

Fernandes dedica algumas páginas à questão da escravidão entre os Tupinambá, pois acredita que esta caracteriza-se como uma relação-chave para

\footnotetext{
${ }^{42}$ Falo aqui em produção de pessoas, pois ao longo da vida um guerreiro poderia adquirir diversos nomes, e o sacrifício ritual geralmente culminava na conquista de um novo nome para o guerreiro, o que implicaria na transformação de sua personalidade (FERNANDES, 2006 [1952]) uma vez que, entre as populações de matriz cultural Tupi o nome consiste na própria essência/alma/espírito da pessoa (SCHADEN, 1962).
} 
compreender o mecanismo de formação e consolidação dos indivíduos adultos do sexo masculino ${ }^{43}$. Neste contexto, os cativos integravam a sociedade Tupinambá, desposando mulheres da aldeia (geralmente filhas e/ou irmãs de seu captor), participando das atividades rotineiras de pesca e caça, além de gozar de plena liberdade para transitar na aldeia e fora dela.

Mesmo gozando de liberdade, não era prática comum entre os cativos a fuga, pelo contrário, afirma Fernandes que o prisioneiro aguardava sua morte de maneira honrada por considerar uma vergonha/fraqueza fugir de seu destino (a morte ritual seguida de antropofagia). Este fato mostra que ambos, guerreiro e prisioneiro, vivem sob a mesma estrutura social e compartilham o mesmo sistema simbólico ${ }^{44}$.

Nestes rituais, voltados para formação e consolidação do guerreiro masculino, as mulheres cumpriam importante papel. Segundo Carvalho (1999) elas eram responsáveis pela confecção das vasilhas que conteriam o cauim e das tigelas que receberiam as entranhas do prisioneiro, além de ornamentar com pinturas as vasilhas, a arma utilizada para o sacrifício (chamada ibirapema), o prisioneiro e o guerreiro (Figura 36), tornando-os parte de uma mesma unidade.

"Uma decoração muito esmerada aparece, de fato, não só nas bordas dos grandes vasos de cauim, no interior dos alguidares - que servia, tanto para a farinha de mandioca, para a fabricação do cauim, quanto para receber as entranhas do prisioneiro sacrificado - como também no ibirapema e na testa do prisioneiro a ser morto.

(...)

Também a tatuagem feita no corpo dos guerreiros que sacrificavam um prisioneiro obedecia aos mesmos padrões da cerâmica e do ibirapema" (CARVALHO, 1999: 9).

\footnotetext{
${ }^{43}$ Segundo Fernandes mulheres também poderiam ser capturadas em guerra e mantidas cativas sendo consequentemente sacrificadas em rituais, assim como os homens. No entanto, o tratamento para ambos os sexos era diferenciado. Enquanto o homem desposaria mulheres (geralmente filhas ou irmãs de seu senhor) que se dedicavam ao seu cuidado, as mulheres cativas desposavam seus senhores (ou ainda eram ofertadas a amigos e parentes de seu senhor) assumindo a função de servi-los e cuidar de sua roça.

${ }^{44}$ A antropóloga Bertha Ribeiro (1987) aponta para situação semelhante entre dois povos xinguanos de matriz cultural Tupi. Segundo a autora, kaiabí e apiaká vivem em constante conflito, porém, se reconhecem como partes de um mesmo grupo, pois ambos falam a mesma língua, estabelecem relações de trocas e matrimoniais. Da mesma forma, sugere a autora, os diversos grupos reconhecidos como Tupinambá poderiam estabelecer relações belicosas com grupos afins, pois ambos compartilham do mesmo sistema simbólico.
} 


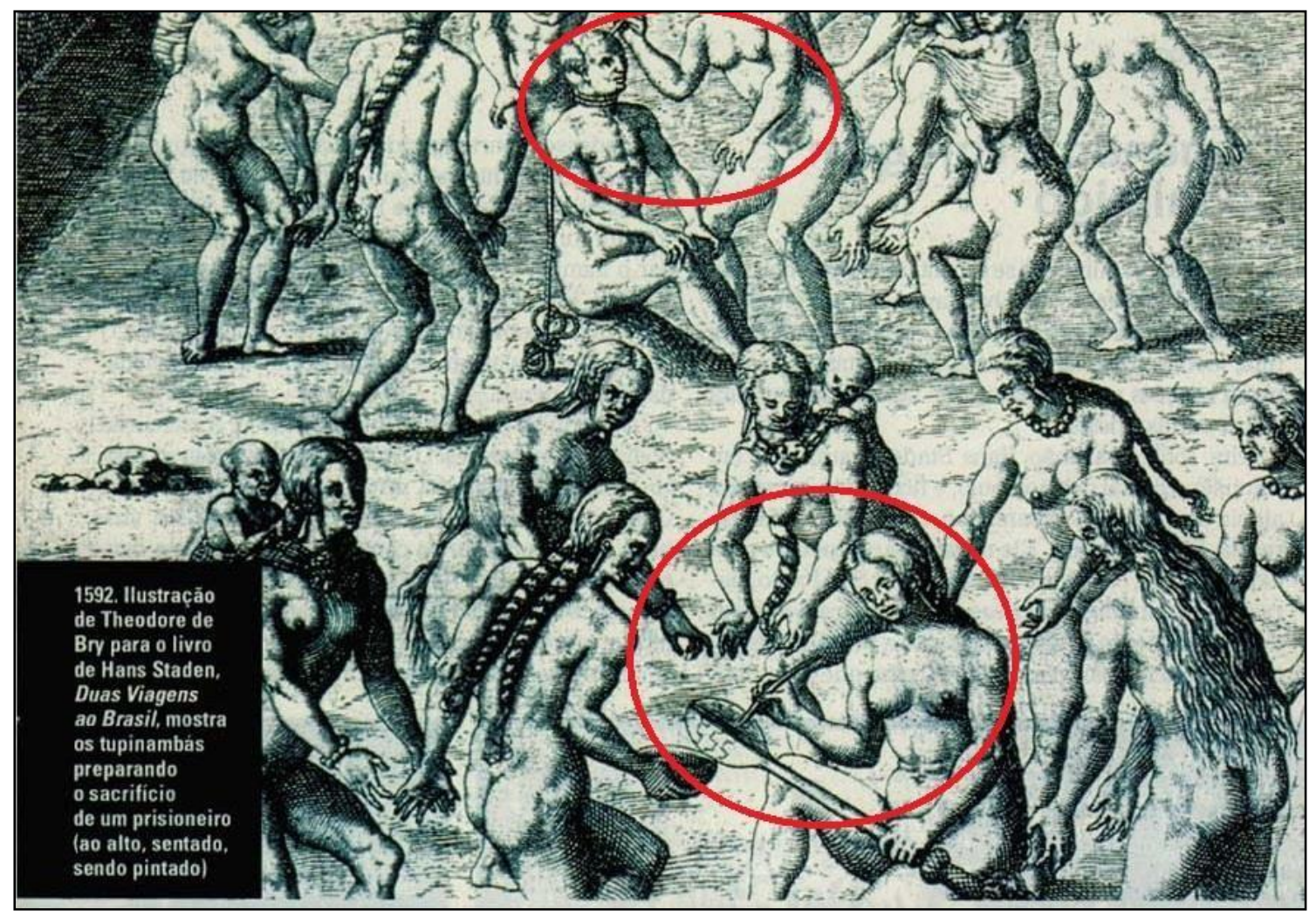

Figura 36: Mulherespreparamoprisioneiropara amorteritual. Ilustração de Theodorede Bryparaolivrode Hans Staden

Segundo Carvalho, grandes guerreiros apresentam uma série de tatuagens no corpo, as quais comunicavam sua valentia em batalhas, como se escrevesse no próprio corpo sua trajetória de guerreiro. Neste sentido, as tatuagens ${ }^{45}$ e pinturas corporais consistiam em uma proteção de combate, desorientando o inimigo que busca atingi-lo.

"Cremos que esta técnica [a pintura corporal] está relacionada a uma defesa real que as pinturas e tatuagens deveriam representar para os guerreiros em combates de lança e arco-e-flecha, em que, logicamente, o inimigo tem que fazer mira para as partes vitais, isto é, tem que escolher, em frações de segundo, um alvo no corpo do oponente" (CARVALHO, 1999: 10).

Gell (1998) utiliza o conceito de "tecnologias de encantamento" para discorrer acerca da capacidade de certos instrumentos (de arte) que possuem o poder de agir sobre as pessoas, desencadeando uma série de eventos e/ou reações. Para o autor, entre populações não ocidentais é comum que objetos rituais sejam produzidos e ornamentados com esmero, recebendo desenhos que

\footnotetext{
${ }^{45}$ Abbeville (1879) descreve a prática de alguns guerreiros de estampar o próprio corpo com pequenas feridas, injetando pigmentos escuros, a fim de marcar de forma permanente a própria pele. "Os maiores e valentes guerreiros, para serem mais estimados pelos seus, e temidos pelos inimigos, tem o costume de, com o osso da canela de certos pássaros, que afiam como navalha de barba, picar e fazer certas figuras no corpo, como se faz com o buril nas couraças. Julgam haver nisto grande coragem, e esfregando nestas incisões alguma cór negra de pó, de succo de qualquer planta, ou do que quer que seja, que se mistura com o sangue, que gira por todas as partes, este introduz-se nas ditas incisões, e assim fixa as figuras de maneira inalterável" (p. 317-318).
} 
se assemelham a labirintos. O mesmo sugere Carvalho (1999) ao dissertar sobre os desenhos presente nos elementos que circulam nos rituais antropofágicos Tupinambá (guerreiro, prisioneiro, ibirapema e vasilhas), onde motivos complexos se repetem em diversos sentidos com a intenção de confundir o observador.

Ainda sobre a repetição dos motivos, a autora ressalta que, embora sejam eles os mesmos para o guerreiro e o prisioneiro, as partes do corpo que recebem a pintura são diferentes: enquanto o prisioneiro recebe a pintura na testa, o guerreiro recebe suas tatuagens abaixo da linha dos olhos. O mesmo acontece na produção cerâmica, onde o mesmo motivo pode se apresentar como principal/primário em uma vasilha e como complementar/secundário em outras (CARVALHO, 1999).

Além da representação humana, alguns autores (PROUS, 2000, 2011; TOCHETTO, 1996) sugerem que os motivos sinuosos podem representar a figura da cobra, personagem constante na mitologia de diversos povos indígenas brasileiros (LÉVI STRAUSS, 1991). Alguns padrões, frequentemente descritos como "ampulheta", lembram o formato da cabeça de cobra, assim como o padrão que identifiquei na vasilha MSNA-04 (Figura 37).

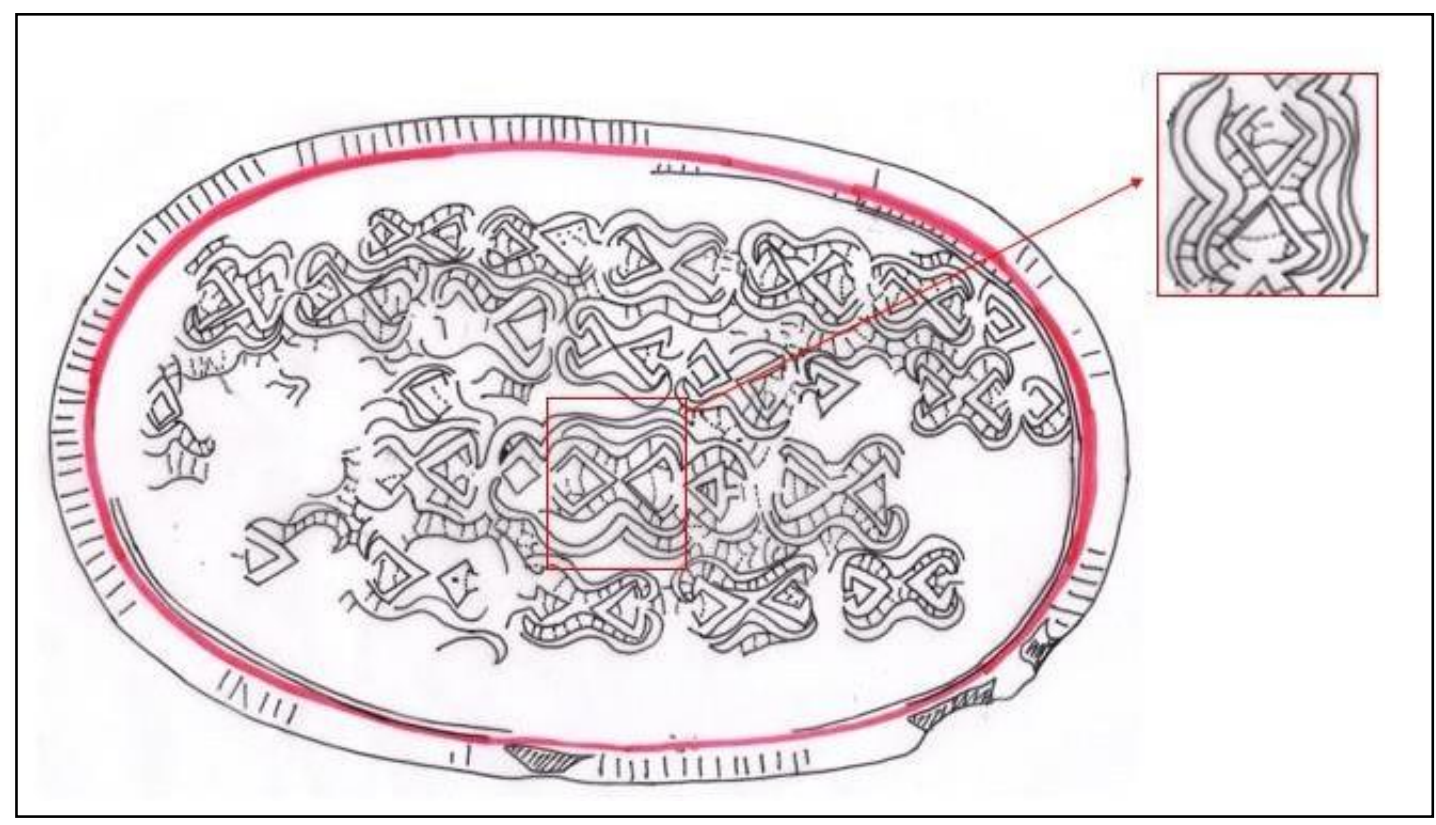

Figura 37: Vasilha MSNAQ 04 com padrão "ampulheta" 
Segundo o antropólogo Pierre Clastres (1990), na mitologia Guarani a cobra/serpente, tal como no mito cristão, é a primeira a poluir a terra, sendo, portanto, associada ao perigo e à morte.

Barreto (2008) e Lagrou (2007) apontam para constante representação da cobra entre as populações indígenas amazônicas, sejam elas pré-coloniais ou atuais. Neste contexto, a cobra (um animal que circula em ambientes diversos: o terrestre e o aquático) pode ser entendida como a representação de um ser sobrenatural que transita entre mundos (o mundo humano e mundo dos espíritos) e aparece em algumas narrativas associada à descoberta da ayahuasca.

Entre as vasilhas que foram alvo de análise nesta pesquisa, pude notar que os motivos curvilíneos são mais abundantes nas em vasilhas abertas (ñaembé/teembirú), por sua vez mais recorrentes em regiões próximas ao litoral (como no Vale do Jacareí). Passo agora a outro motivo bastante explorado: o retilíneo.

\section{Motivos retilíneos}

Além dos rituais antropofágicos, as vasilhas cerâmicas também estavam presentes nos sepultamentos daqueles guerreiros que não encontraram a morte em batalha. Nestes casos, vasilhas do tipo cambuchí e yapepó (esta última utilizada no preparo de alimentos por fervura) assumiam a função de urnas funerárias, abrigando o corpo do guerreiro morto, além de alguns objetos como vasilhas menores (cambuchí caguâba). Outras vasilhas ainda lhes serviam de tampas (provavelmente ñaembé/teembirú reaproveitados dos rituais antropofágicos) a fim de evitar que o corpo permanecesse em contato direto com a terra, uma vez que, segundo Carvalho (1999), no sepultamento primário em urnas "o morto é transformado simbolicamente em cauim e em alimento, num festim de Tântulo, ainda não recusado pelos deuses" (p. 13).

Nas vasilhas do tipo cambuchí que analisei, pude identificar alguns padrões formados a partir da composição de linhas retas na horizontal e na vertical, que podem sugerir a representação de figuras antropomorfas ou 
zoomorfas, tais como o padrão tayngava (Figura 38) identificado por Regina Müller (1992) entre os Assurini do Xingu, ou o padrão tanga/taangap (Figura 40) identificado por Ribeiro (1987b) em alguns artefatos (cestarias, cuias e bordunas) e na pintura corporal dos Kaiabí do Xingu (grupo de matriz cultural Tupi).

No primeiro caso, o padrão tayngava pode ser considerado uma formabase que origina os diversos motivos/representações utilizados pelos Assurini a partir de combinações diferentes. Além disso, segundo a autora, este padrão está relacionado com a própria ideia de "constitutivo do ser" (ynga = princípio vital, Ava = gente, acrescida do prefixo "t" - forma gramatical que indica possuidor humano), significando, assim, algo como "imagem do ser humano" (MÜLLER, 1992: 241).

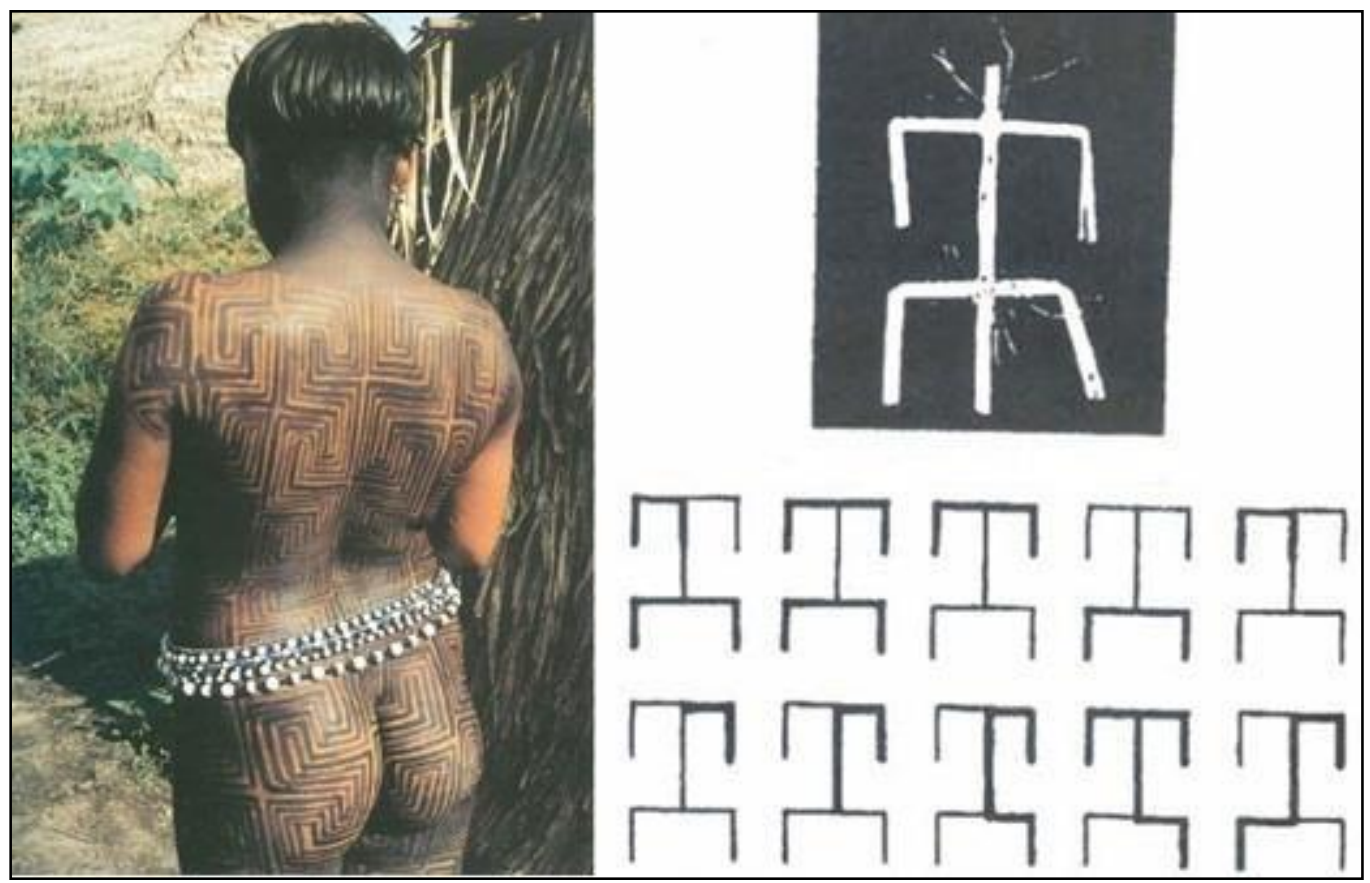

Figura 38: À esquerda o padrão tayngava presente na pintura corporal de um Assurini (MÜLLER, 1992); à direita o motivo mínimo do padrão tayngava (TOCHETTO, 1996)

Já os padrões identificados por Ribeiro (1987b) se assemelham à letra "H" e podem fazer referência à representação de seres mitológicos, sejam eles humanos ou animais (Figura 39). 


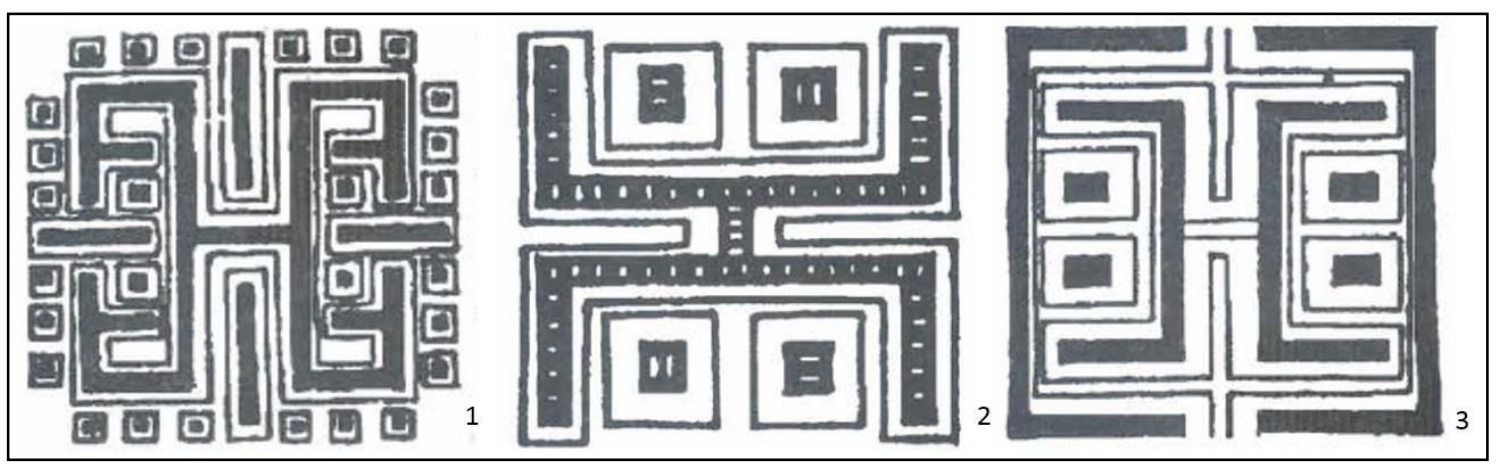

Figura 39: Motivos representativos de seres mitológicos: 1. Taangap faña (gente, dedos esticados/garra); 2. Sapo kururu; 3 taangap ta (criança com o pai) (RIBEIRO, 1987b: 269)

Pude identificar em uma das vasilhas que analisei (Figura 40) padrão muito semelhante ao motivo identificado pela autora como a representação do sapo kuru, cuja pintura é composta por dois campos gráficos, aparentemente com o mesmo padrão, ainda que com larguras diferentes. Os dois campos, complementares entre si, se combinam de modo a formar motivos distintos na mesma vasilha, dentre as quais pude identificar um padrão semelhante ao sapo kururu, podendo também fazer referência à figura humana, e o padrão "cruz", muito representado em vasilhas associadas à ocupação de grupos Tupi, o que já havia sido observado por outros autores (TOCHETTO, 1996; MORAES, 2007; OLIVEIRA, 2008; PROUS, 2005). Interessante notar que os padrões se repetem de maneira quase concêntrica provocando uma ilusão de ótica como se se destacassem de seu suporte a partir de um efeito tridimensional. 


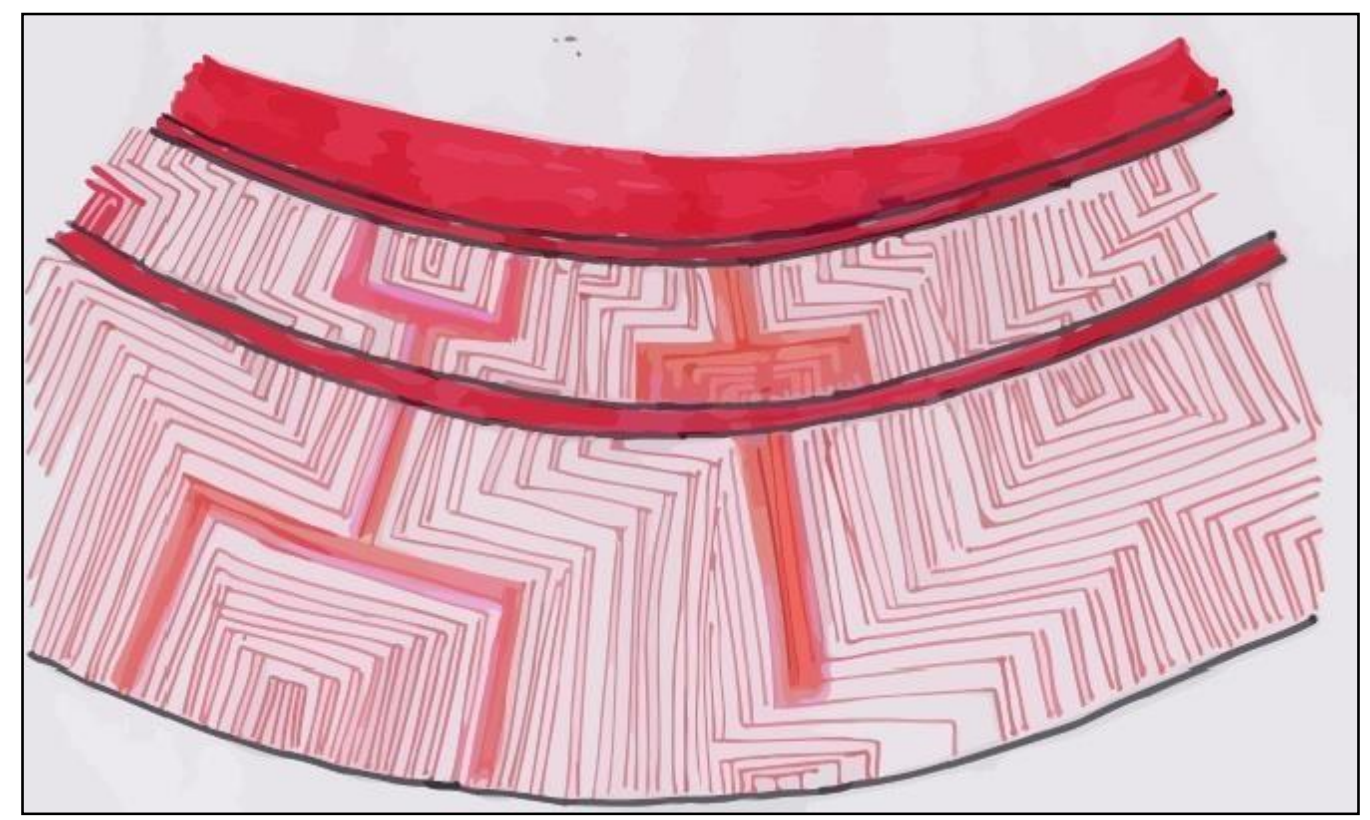

Figura 40: Vasilha (CEMAARQ 10) com motivos "sapo" e "cruz"

Os dois elementos (kururu e "cruz") estão presentes em narrativas míticas originárias de povos Guarani atuais. O primeiro é um dos personagens presentes no mito de origem do fogo, sendo o responsável de roubá-lo dos corvos, que eram os guardiões do fogo. Na versão recolhida por Pierre Clastres (1990 [1974]), o sapo se finge de morto para chamar a atenção dos corvos (ou urubus em algumas versões do mito) e quando estes se aproximam para cozinhá-lo o sapo espalha as brasas, guardando uma pequena porção em sua boca. Ao chegar na terra, o sapo guarda as brasas em um tronco de madeira. É assim que, segundo os Guarani, as pessoas passam a ter acesso ao fogo.

"Bastará aos homens, doravante, produzir fogo pelo método da fricção. Notemos que, para os Guarani, a fricção não produz verdadeiramente o fogo, mas permite simplesmente extraí-lo da madeira, onde já se encontra enclausurado" (CLASTRES, 1990 [1974]: 102-103).

Segundo Lévi Strauss (1986, 1991) o fogo ocupa papel central nas sociedades ameríndias, seu domínio marca a separação entre o mundo natural e o social, uma vez que os humanos consomem alimentos cozidos em oposição aos animais que consomem alimentos crus. Além disso, o fogo está presente também na produção oleira, pois é no processo de queima que a argila se transforma em cerâmica.

Sobre o padrão "cruz", em certa medida, é consenso na literatura arqueológica que aborda a questão dos grafismos entre as cerâmicas Tupi 
que a imagem da cruz pode ser uma representação da "escora da terra", que se mostra presente na mitologia dos Guarani historicamente conhecidos, como é possível notar nos mitos de criação e destruição do mundo dos Apapocúva-Guarani, coletados pelo indigenista Kurt Nimuendaju (1987). Segundo o autor,

"Ñanderuvuçú tinha o sol no peito. E ele trouxe a eterna cruz de madeira [yvy itá]; colocou-a na direção do leste, pisou nela e começou (a fazer) a terra. Hoje a eterna cruz de madeira permanece como escora da terra. Quando ele retira a escora da terra, a terra cai" (NIMUENDAJU, 1987: 143).

Vale ressaltar que alguns autores (PROUS, 2007; OLIVEIRA, 2008) apontam para semelhanças existentes entre a narrativa Guarani e a cristã, no entanto, a recorrência do padrão "cruz" em vasilhas cuja produção precedem o contato com o colonizador é grande e sugerem a presença deste elemento figurativo em um período mais recuado, no entanto devemos considerar a constante reformulação e ressignificação das narrativas mitológicas em diferentes contextos (sociais, temporais e geográficos). Algumas narrativas citam apenas a presença de um bastão (CADOGAN, 1959), logo, é possível que a situação de contato com o "outro", cristão, pode ter feito com que as populações Guarani se apropriassem do termo/ideia da "cruz" como escora da terra a fim de estabelecer uma comunicação mais efetiva com o colonizador ${ }^{46}$.

Sobre esta questão é interessante ressaltar que, Dominique Gallois (1992) aponta para o papel protetor da "cruz" como elemento que serviria de "escudo" contra os possíveis males causado pelo homem branco:

"Os mais velhos mencionam, ainda, uma proteção que participa do mesmo sistema: trata-se de tupana kuruça (a cruz de Tupã), gravada na testa dos homens como proteção contra as armas de fogo ("não morre com canhão, chumbo não acerta"). A tradição atribui este motivo de escarificação aos brancos, que o ensinaram aos Waiãpi "no tempo de Janejar", isto é, na época da criação do universo" (GALLOIS, 1992: 229).

Este padrão também está presente em um cambuchí do MAI (Figura 41), formado por linhas duplas na vertical e horizontal que se entrecruzavam

\footnotetext{
${ }^{46}$ Graciela Chamorro (1995) já sugere a indigenização da cruz, denominada entre os Guarani Kaiowa como kururu.
} 
ao meio. Este padrão-guia é contornado por linhas duplas que se dobram sobre si mesmas de modo a repetir o mesmo motivo.

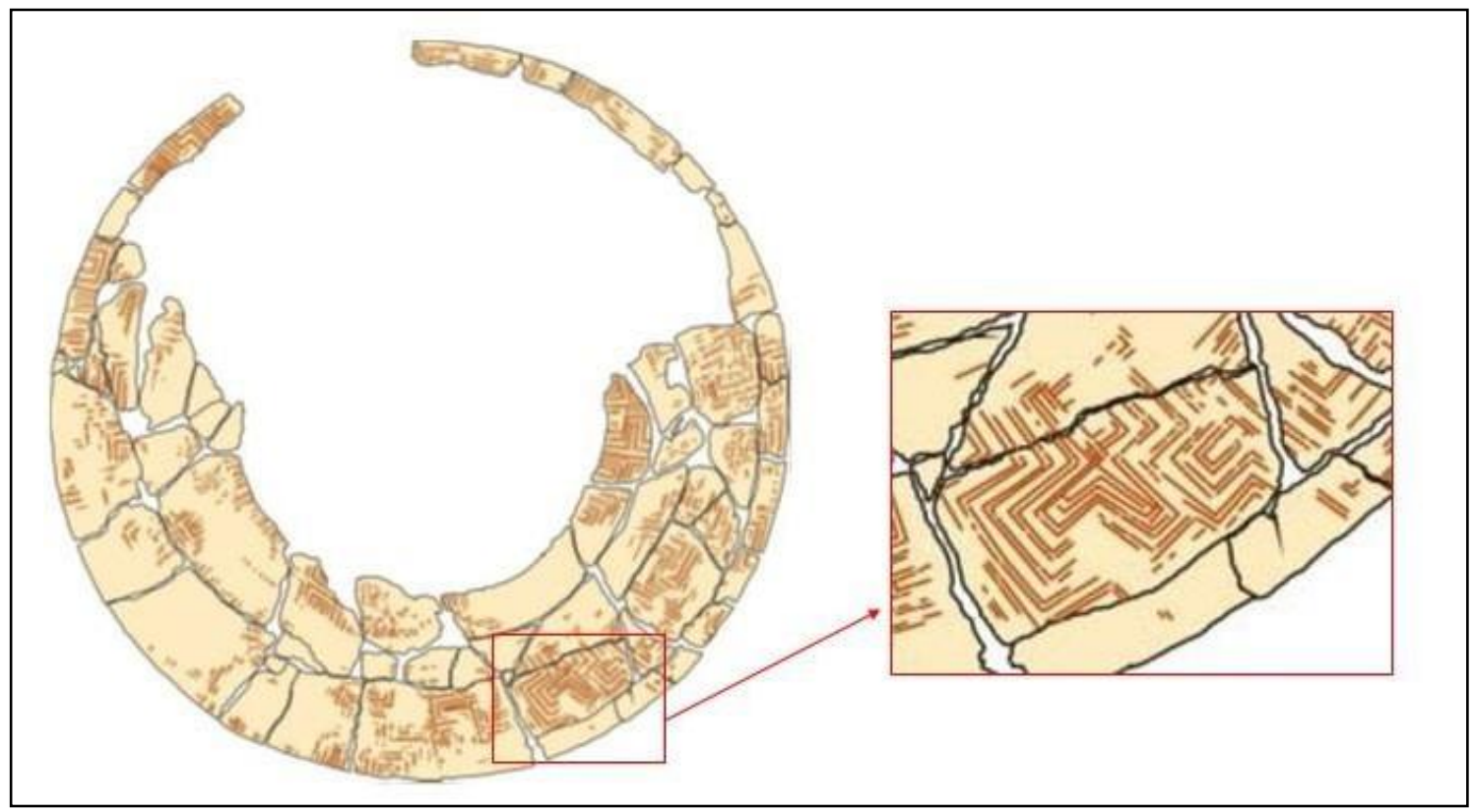

Figura 41: Vasilha do tipo cambuchí (MAI01) com destaque para motivo com padrão "cruz"(Imagem de FACCIO, 2011:160)

No interior paulista Moraes (2007) identificou a presença do padrão "cruz" em fragmentos cerâmicos da coleção particular de Manuel Pereira de Godoy e em urnas funerárias inteiras do sítio Franco de Godoy (Mogi Guaçu). Em ambos os casos os motivos são formados por múltiplas linhas escalonadas que se repetem de maneira concêntrica.

Outro motivo genericamente descrito como meramente geométrico é o "quadrado". Pude identificar este padrão na vasilha CEMAARQ 03 (sítio Alvin, Piraju). O motivo é composto por linhas duplas nos sentidos horizontal e vertical, formando quadrados concêntricos. Este se assemelha com alguns desenhos colhidos por Gallois (1992) entre os Waiãpi na década de 1980. Na ocasião a pesquisadora trabalhou com "desenhos espontâneos" produzidos por diversos indivíduos (homens, mulheres e crianças) tendo como suporte 0 papel e usando como ferramenta canetas coloridas.

Gollois notou que os desenhos produzidos não consistiam na representação de elementos de sua organização social, como ocorria entre outros povos indígenas, tampouco serviam de indicadores sociais de hierarquia. O que os Waiãpi buscavam representar, segundo a pesquisadora, eram seres, espécies naturais e/ou sobrenaturais, são motivos relacionados 
aos mortos e aos inimigos (GALLOIS, 1992: 210). Estes desenhos eram aplicados em suportes diversos: em cuias, nas cerâmicas, nos corpos, etc.

Entre os motivos representativos de animais é possível encontrar o motivo "casco de jabuti" composto por quadrados concêntricos, tal como o padrão que identifiquei na vasilha CEMAARQ 03 (Figura 42).

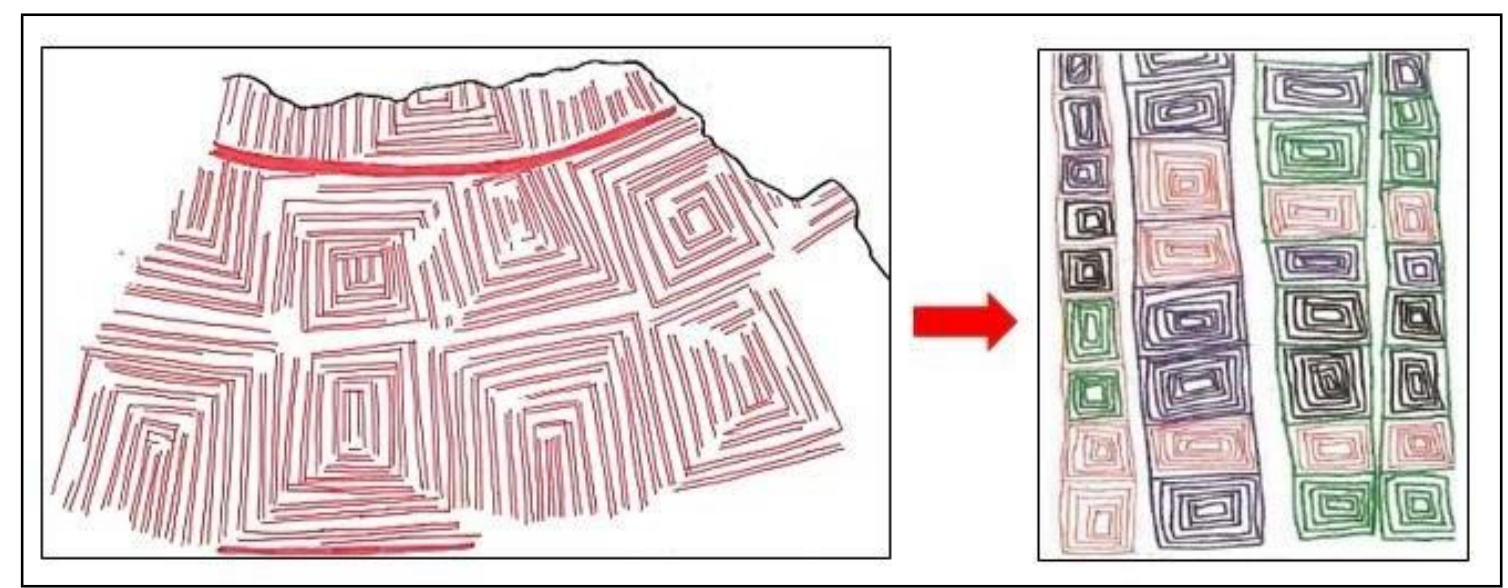

Figura 42: Desenho "casco de jaboti" presente na vasilha CEMAARQ 03 (à esquerda) e reproduzido em papelpor Nazaré, Waiãpi (GALLOIS, 1992: 214)

Interessante notar que, assim como a vasilha CEMAARQ 10, a vasilha CEMAARQ 03 apresenta o mesmo efeito tridimensional. Este efeito pode ser intencional, pois como aponta Jussara Gruber (1992) ao estudar a arte Ticuna (autodenominados Magüta, povo de língua Tikuna), alguns motivos representativos de parte de animais (como "casco de jabuti" ou a "escama de samoatá") tem como objetivo representar texturas.

Não identifiquei a figura do jabuti em registros de narrativas míticas de povos Tupi atuais. No entanto, sua figura parece ser uma constante na representação gráfica de populações amazônicas, sobretudo na pintura corporal (SILVA \& FARIAS, 1992; VIDAL, 1992; GALLOIS, 1992). Segundo Netto (1885), o jaboti/cágado (e outras espécies) ocupam espaço importante na alimentação dos povos amazônicos. Ao contrário do que sugere seus gestos vagarosos, o jaboti aparece nas narrativas mitológicas amazônicas associada à astúcia e esperteza (NETTO, 1885). 


\section{Considerações Finais}

Sobre os dados de análise

Diante da variedade de utensílios cerâmicos presentes atualmente nos museus do estado de São Paulo, optei neste estudo em me concentrar naqueles que apresentavam pinturas, com o objetivo de me aproximar de aspectos subjetivos da cultura de populações Tupi, pois como sabemos, estas vasilhas estão frequentemente associadas a contextos arqueológicos específicos, como sítios cemitérios ou cerimoniais.

De maneira geral, me concentrei em dois objetivos principais, a saber: compreender os usos e papel social das vasilhas cerâmicas em foco e identificar a existência de estilos regionais na produção oleira a partir da leitura dos padrões decorativos na tentativa de refinar o diálogo entre vestígio arqueológico e narrativas etnohistóricas, buscando na materialidade as particularidades de grupos étnicos que ocuparam o interior paulista no passado.

No decorrer da pesquisa me deparei com um volume muito pequeno de vasilhas inteiras, consequentemente, o volume de motivos e padrões gráficos identificados também foram reduzidos, o que impossibilitou a definição de estilos regionais específicos.

Neste contexto, foi possível identificar, tanto nos aspectos tecnológicos como decorativos das vasilhas analisadas, um corpo de características tecnológicas, formais e estilísticas que sugerem a permanência e continuidade de saberes tradicionais que permeiam a produção oleira destes povos e que podem ser entendidos como marcadores culturais, pois foram difundidos por longos períodos de tempo atingindo consequentemente uma vasta dispersão territorial.

Estes traços são evidenciados, sobretudo, nas escolhas dos elementos que compõem a pasta (uso de caco moído como antiplásticos), no contorno das vasilhas (que varia entre formas carenadas e vasilhas abertas com contorno simples) e nos padrões decorativos (delimitação dos campos 
gráficos com bandas vermelhas, motivos em cores vermelhas e/ou pretas sobre fundo branco) que seguem um modelo pré-concebido pelas ceramistas, os quais já descritos em trabalhos voltados para a cerâmica de populações Tupi (PRONAPA, 1969; LA SALVIA \& BROCHADO, 1989; BROCHADO \& MONTICELLI, 1990, 1994; NOELLI, 1993, SCATAMACHIA, 2004; MORAES, 2007; PROUS, 2009, 2011).

No que compete aos padrões decorativos, a espacialização dos padrões identificados nos permitiu reafirmar o modelo proposto por Brochado (1984) sobre a dispersão das populações Tupi nos sentidos meridionais (Guarani) e litoral (Tupinambá).

Tal modelo tão consagrado no cenário arqueológico nacional é defendido por pesquisadores recentes, entre eles Correa (2014) que avança no modelo inicial de Brochado no que compete aos vestígios cerâmicos, identificando não mais dois, mas cinco conjuntos cerâmicos atribuídos às populações de língua Tupi, são eles: Tupi Norte Ocidental, Tupi Norte Oriental, Proto Tupinambá, Tupinambá e Guarani. Neste contexto, segundo o autor, a região entre Tietê e Paranapanema consiste em uma área de encontro dos grupos produtores da cerâmica Guarani e Tupinambá.

Dentre as vasilhas que analisei na região supra citada (abrangendo sobretudo os municípios Presidente Prudente, Presidente Epitácio e Rosana), pude observer a coexistência de vasilhas com motivos curvilineos, confeccionados a partir de linhas muito finas em vermelho e preto, características associadas ao conjunto Tupinambá ${ }^{47}$ e vasilhas com motivos retilíneos, confeccionados a partir de linhas mais grossas, associadas ao conjunto Guarani ${ }^{48}$.

Sobre a relevância da pesquisa para o contexto arqueológico paulista

Acredito que as contribuições de minha pesquisa se dão em dois aspectos. $O$ primeiro diz respeito à divulgação e valorização de instituições de

\footnotetext{
${ }^{47}$ Ver motivos apresentados no Grupo A - Prancha 05.

${ }^{48}$ Ver motivos apresentados nos grupos C e D - Prancha 05.
} 
guarda e acervos do interior paulista, uma vez que grande parte das coleções que integraram esta pesquisa não foram alvo de pesquisa de outros arqueólogos(as). Neste sentido, as coleções aqui apresentadas podem ganhar visibilidade no meio acadêmico a partir desta dissertação e outras publicações que possam ser produzidas a partir deste estudo. Além disso, pesquisar coleções consiste em contribuir com a formação dos funcionários/educadores dos museus e, possivelmente, fomentar novas exposições e materiais de divulgação sobre acervos em exposição.

Outra contribuição relevante seria o início de um debate mais aprofundado sobre os aspectos decorativos e do papel agentivo dos artefatos cerâmicos a partir de uma leitura antropológica da arte e da semiótica, considerando que grande parte das pesquisas no estado de São Paulo acontecem no âmbito da arqueologia de contrato e que, embora gerem dados importantes e tragam à baila contextos desconhecidos e/ou poucos pesquisados, desenvolvem pesquisas rasas, frequentemente centradas nos aspectos tecnológicos e funcionais dos objetos.

\section{Sobre os desafios da pesquisa com coleções}

Assim como muitos(as) pesquisadores(as) me deparei com algumas dificuldades ao longo da pesquisa no que se refere ao acesso às coleções e documentação (primária ou museológica) a respeito.

Não raro nos deparamos com coleções cuja biografia são desconhecidas por suas instituições de guarda. Isso acontece devido a diversos fatores, um deles diz respeito à própria história da arqueologia e da formação de acervos museológicos no Brasil, uma vez que a preocupação em documentar contextos in situ é uma prática relativamente recente na arqueologia brasileira, que se manteve por muito tempo voltada ao colecionismo de objetos "exóticos" e "belos". Neste contexto é comum que instituições e acervos antigos apresentem lacunas nas narrativas que envolvam os objetos. Ainda nos dias atuais é possível notar certa desorganização com relação à documentos e acervos arqueológicos, seja por parte dos(as) arqueólogos(as) responsáveis pelas pesquisas, das instituições 
de guarda e/ou do próprio poder público que não possui políticas públicas que prezem pela guarda, preservação e comunicação de acervos.

\section{Sugestões para continuidade da pesquisa}

Creio que o um dos maiores problemas deste trabalho seja a o volume reduzido de dados, uma vez que optei por trabalhar com vasilhas com alto grau de integridade. Neste sentido, conforme sugestões da banca, futuras pesquisas possa incorporar dados de fragmentos de bordas, paredes angulares e/ou outros fragmentos que permitam a reconstituição de formas a partir da bibliografia arqueológica e que por sua vez apresentem motivos em bom estado de preservação.

Também seria importante o aprofundamento das etnohistóricas regionais, incluindo no discurso arqueológico as narrativas dos povos indígenas atuais sobre como percebem o registro arqueológico a partir de suas experiências individuais e coletivas. 


\section{Referências Bibliográficas}

AFONSO, M. C. Resgate Arqueológico dos Sítios Água Branca, Lambari I e Lambari II (Municípios de Casa Branca e Mococa, SP). Relatório Final, MAE/USP. São Paulo, 2001.

AFONSO, M. C. Um olhar para a arqueologia pré-histórica do Estado de São Paulo. Tese (Livre Docência) - Universidade de São Paulo, São Paulo, 2005

AFONSO, M. C.; MORAES, C. A. de. O Sítio Água Branca: interações culturais dos grupos ceramistas no norte do estado de São Paulo. Revista do Museu de Arqueologia e Etnologia. 15-16. São Paulo, 2006. (P. 59-71)

ALCANTARA, A. A. Paulo Duarte entre sítios e trincheiras em defesa da sua dama - a Pré-história. Dissertação MAE/USP. São Paulo, 2008.

ALMEIDA, A. Sorocaba: 3 séculos de história. Ottoni. Itu - SP, 2002.

ALTENFELDER SILVA, F. Informes preliminares sobre a arqueologia de Rio Claro. Programa Nacional de Pesquisas Arqueológicas - Resultados Preliminares do Primeiro Ano / 1965-1966. Museu Paraense Emilio Goeldi, Publicacoes Avulsas. Belém, 1967.

ALTENFELDER SILVA, F. Arqueologia pré-histórica da região de Rio Claro. Pré-Historia Brasileira, IPH/USP. São Paulo, 1968.

ALVES, M.A. Análise Cerâmica: estudo tecnotipológico. Tese de Doutorado. Faculdade de Filosofia, Letras e Ciências Humanas/USP. São Paulo, 1988

ARAÚJO, A.G.M. de. Arqueologia na Região de Rio Claro: uma síntese. Revista do Museu de Arqueologia e Etonologia n. 11. São Paulo, 2001.

ASCHER, R. Analogy in Archaeological Interpretation. In: Deetz, J. (Ed.). Man's Imprint from the Past. Boston, Little Brown. 1971. (P. 262-271).

AYTAI, D. Um estilo de decoração tupi: ordem no caos. Publicação do Museu Municipal de Paulínia n. 48. Paulínia (SP), 1991. (P. 22-35).

BARRETO, C. N. G. de B. A Construção de um Passado Pré-colonial: uma breve história da arqueologia no Brasil. Revista USP, n. 44. São Paulo, 1999/2000. (P. 32-51).

BARRETO, C. N. G. de B Meios Míticos de Reprodução Social: arte e estilo na cerâmica funerária da Amazônia antiga. Tese (Doutorado) - MAE/USP. São Paulo, 2008.

BERNARDO, W. E. Sorocaba, $\mathbf{3 4 3}$ anos de fundação...mais de $\mathbf{5 0 0}$ anos de história. Documento do Museu Histórico Sorocabano, sd.

BERNARDO, W. E. Índios em Sorocaba. Disponível em $<$ http://www.sorocaba.com.br/enciclopediasorocabana/index.php/files/?local=tit ulos\&tipo=verbetes\&ler $=1100458664>$, acesso em 23/03/2016.

BOAS, F. Arte Primitiva. Mauad. Rio de Janeiro, 2015. 
BOURDIEU, P. Sociologia. (organizado por Renato Ortiz). Editora Ática. São Paulo, 1983.

BROCHADO, J. P. Migraciones que difundieron la tradición alfarera Tupiguarani. Relaciones - Sociedad Argentina Antropologia. Nova Série, Buenos Aires VII, 1973.

BROCHADO, J. P. An ecological model of spread of pottery and agriculture into eastern South America. Tese de Doutoramento, University of Illinois at Urbana-Chapaign, 1984.

BROCHADO, J. P. A expansão dos Tupi e a cerâmica da tradição Policrômica amazônica. Dédalo, São Paulo, USP, n.ำ 27. 1989

BROCHADO, J. P. MONTICELLI, G. Regras práticas na reconstituição gráfica da cerâmica Guarani por Comparação com vasilhas inteiras. Estudos Ibero-americanos. 20 (2): 107-118, 1994.

BROCHADO, J. P. MONTICELLI, G. Analogia Etnográfica na reconstituição gráfica das vasilhas Guarani Arqueológicas. Veritas, PUCRS, 35 (140), 1990

BUARQUE, A. As estruturas funerárias das aldeias Tupinambá da região de Araruama, RJ. In: Os Ceramistas Tupiguarani. Vol. III. Eixos Temáticos. Belo Horizonte, Superintendência do IPHAN em Minas Gerais, 2010, p. 149-172.

CABRERA, J. I. A. O espaço ocupado pelo homem pré-histórico no oeste paulista: o caso do sítio arqueológico Lagoa São Paulo 02 no municipio de Presidente Epitpacio - SP. Tese de Doutorado FCT/UNESP. Presidente Prudente, 2015.

CADOGAN, L. Ayvu Rapyta. Textos míticos de los Mbyá-Guarani del Guairá. Universidade de São Paulo, Fac. Fil.Ciênc, e Letras, Boletim n. 227, Antropologia n. 05. São Paulo, 1959.

CAMARGO, C.B.R. Arqueologia do Vale do Paraíba - Escavações em Aparecida. Texto impresso por ocasião do X Simpósio de História do Vale do Paraíba. Roseira, 1990.

CARVALHO, S. M. S. A morte heroica do guerreiro. In: CARVALHO, S.M.S. (Coord.) Rituais Indígenas Brasileiros. CPA Editora Ltda. São Paulo, 1999.

CEREZER, J. F. Cerâmica Guarani - Manual de Experimentação Arqueológica. Habilis Press Editora. Erechim, RS, 2011.

CHAMORRO, G. Kurusu Ñe'ëngatu: palavras que la historia no podría olvidar. IEPG/COMIN. São Leopoldo, 1995.

CHMYZ, I. Terminologia Arqueológica Brasileira para a Cerâmica. Universidade Federal do Paraná. Curitiba, 1966.

CLASTRES, H. Terra sem Mal: o profetismo tupi-guarani. Editora Brasiliense. São Paulo, 1978.

CLASTRES, P. A fala sagrada: mitos e cantos sagrados dos índios Guarani. Tradução Níeia Adan Bonatti. Papirus. Campinas, 1990. 
CORREA, A. Pindorama de Mboîa e l̂akaré: continuidade e mudança na trajetória das populações Tupi. Tese de Doutorado MAE/USP. São Paulo, 2014.

COSTA, A. Introdução à Arqueologia Brasileira. Etnografia e História. $2^{\mathrm{a}}$. Edição. Companhia Editora Nacional. Rio de Janeiro, 1934.

DEETZ, J. Invitation to archaeology. The Nat. History. Garden City, NY, 1967.

DIAS, A. S. Um projeto para a arqueologia brasileira. Breve histórico da implantação do PRONAPA. Revista do Centro de Ensino e Pesquisa da Universidade Federal do Paraná, 1995. (P. 22:25-39)

DIAS, A. S.; NEUMAN, M. A.; MONTEIRO, R.; PASSOS, M. M. dos; MEIRELLES, P. V. M.; MARQUES, R. P. O discurso dos fragmentos: sóciocosmologia e alteridade na cerâmica Guarani pré-colonial. Espaço Ameríndio, v. 2 n². Porto Alegre, 2008

DIAS JR., O. A Tradição Tupiguarani no estado do Rio de Janeiro. Estado da arte das pesquisas arqueológicas sobre a Tradição Tupiguarani. Juiz de Fora: EDUFJF, 2009, p. 65-88.

FACCIO, N. B. Estudo do sítio arqueológico Alvim no contexto do Projeto Paranapanema. Dissertação de Mestrado. FFLCH/USP. São Paulo, 1992.

FACCIO, N. B. Arqueologia dos cenários das ocupações horticultoras da Capivara, Baixo Paranapanema. Tese de Doutorado. FFLCH/USP. São Paulo, 1998.

FACCIO, N. B. Arqueologia Guarani na área do Projeto Paranapanema: estudos dos sítios de lepê, SP. Relatório de Livre-docência - Museu de Arqueologia e Etnologia/USP. São Paulo, 2011.

FACCIO, N. B. LOPPES, P. R. O Sistema Regional de Ocupação do Vale do Rio Paranapanema no Período Pré-Colonial. Anais do $X$ Encontro de Geógrafos da América Latina. Universidade de São Paulo. São Paulo, 2005.

FERNANDES, F. A função social da guerra na sociedade Tupinambá. Prefácio Roque de Barros Laraia, 3. ed. Globo. São Paulo, 2006.

FONSECA, D. P. O Viajante Hércules Florence: águas, guanás e guaranás. Pontes. Campinas, 2008.

FRIOLLI, A. A bacia do rio Sorocaba na formação pré-histórica da região. Documento Museu Histórico Sorocabano, sd.

FUNARI, P. P. Arqueologia. Contexto. São Paulo, 2010.

Funari, P. P. Memória Histórica e Cultura Material. Revista de Ciências Históricas. Porto, 10, 1995.

GALOIS, D. T. Arte iconográfica Waiãpi. In: VIDAL, L. VIDAL, L. (Org.) Grafismo Indígena: estudos de antropologia estética. Edusp. São Paulo, 1992. 
GARCIA, E. F. O projeto pombalino de imposição da língua portuguesa aos índios e a sua aplicação na América meridional. Tempo [online]. 2007, vol.12, n.23, pp.23-38.

GELL, A. Art and Agency: an Anthropological Theory. Oxfor: Clarendon, 1998.

GELL, A. A rede de Vogel, armadilhas como obras de arte e obras de arte como armadilhas." In: Arte e Ensaios - Revista do Programa de PósGraduação em Artes Visuais. Escola de Belas Artes/UFRJ. ano VIII - n.8. Rio de Janeiro, 2001. P. 174-191.

GEERTZ, C. O saber local: novos ensaios em antropologia interpretativa. Editora Vozes. Petrópolis - RJ, 1997.

GODOY, M. P. Los extinguos painguá de la cascada de Emas (Estado de São Paulo - Brasil). Imprenta de La Universidad Cordoba, República Argentina, 1946.

GODOY, M. P Contribuição à História Natural e Geral de Pirassununga. Prefeitura municipal de Pirassununga, v. 1. 1974.

GOSDEM, C. What do Objects Want? Journal of Archaeological Method and Theory, v. 12, n. 3. September, 2005

GOULART, M. Novas Perspectivas de análise cerâmica em pré-história brasileira. Tese de Doutorado. FFLCH/USP. São Paulo, 1982.

GRUBER, J. G. A arte gráfica Ticuna. In. VIDAL, L. (Org.) Grafismo Indígena: estudos de antropologia estética. Edusp. São Paulo, 1992.

HEGMON, M.; KULOW, S. Painting as Agency, Style as Structure: Innovations in Mimbres Pottery Designs From Southwest New Mexico. Journal of Archaeological Method and Theory, Vol. 12, No. 4. December, 2005.

HODDER, I. The Present Past: an introduction to anthropology for archaeologists. Batsford. London, 1982.

HODDER, I. Interpreting Archaeology: finding meaning in the past. Routledge. New York, 1995.

HODDER, I. Archaeological Theory Today. Cambridge, UK. Polity Press Malden, MA: Black Well Publishers, 2002.

JÁCOME, C. P. Ayquatiá da Yapepó: Estudo dos Materiais Utilizados na Cerâmica Pintada Tupiguarani de Minas Gerais. Dissertação de Mestrado Escola de Belas Artes UFMG. Belo Horizonte, 2006.

JECUPÉ, K. W. A terra dos mil povos: história indígena brasileira contada por um índio. Série Educação Para a Paz. Peirópolis. São Paulo, 1998.

KASHIMOTO, E. M. Variáveis Ambientais e Arqueologia no Alto Paraná. São Paulo: USP, Tese (Doutorado em Arqueologia) - Museu de Arqueologia e Etnologia, Universidade de São Paulo, 1997. 
KNAPP, B. Archaeology without gravity. Posmodernism and the past. Journal of Archaeological Method and Theory, 3(2). 1996. (P. 109-125).

KÜNZLI, R. Arqueologia regional: primeiros resultados das pesquisas realizadas na área de Presidente Prudente. Revista do Museu Paulista, v. 32, n. 5. São Paulo, 1987.

LA SALVIA, F. BROCHADO, J. P. Cerâmica Guarani. Posenato Arte \& Cultura. Porto Alegre, 1989.

LADEIRA, M. I. O Caminhar Sob a Luz: território mbya à beira do oceano. Editora Unesp/FAPESP. São Paulo, 2007.

LAGROU, E. Antropologia e arte: uma relação de amor e ódio. PPGASUFRJ. Rio de Janeiro, 2003

LAGROU, E. A Fluidez da Forma: arte, alteridade e agência em uma sociedade amazônica (Kaxinawa, Acre). Topbooks Editora. Rio de Janeiro, 2007.

LAGROU, E. Existiria uma arte das sociedades contra o Estado? Revista de Antropologia US, v. 54 n². São Paulo, 2011.

LATHRAP, D. The Upper Amazon. Thames \& Hudson. London, 1970.

LAYTON, R. The Anthropology of Art. Cambridge University Press.Cambrige,1991.

LEMONNIER, P. Technological Choices: transformation in material cultures since the Neolithic. Routledge. London and New Your, 1993.

LÉRY, J. de. Viagem à Terra do Brasil. Tradução Sérgio Miliet. Biblioteca do Exército, 1961.

LÉVI-STRAUSS, C. Antropologia Estrutural. Tempo Brasileiro. Rio de Janeiro, 1975.

LÉVI-STRAUSS, C. Antropologia Estrutural II. Cosac Naify. São Paulo, 2013

LÉVI-STRAUSS, C. As Estruturas Elementares do Parentesco. Vozes. Petrópolis, 1982.

LÉVI-STRAUSS, C. O cru e o Cozido. As mitológicas Brasiliense. São Paulo, 1991.

LÉVI-STRAUSS, C. A oleira ciumenta. As mitológicas. Brasiliense. São Paulo, 1986.

LOPES, M. Ocupação Tupinambá no vale do Paraíba Paulista: vista a partir da análise do sítio arqueológico Santa Maria. Dissertação de Mestrado MAE/USP. São Paulo, 2014

MADEIRA, J. L. O Desenho na Arqueologia. Instituto de Arqueologia da Faculdade de Letras de Coimbra. Coimbra, 2013.

MALINOWSKI, B. Argonautas do Pacífico Ocidental. Os Pensadores. Abril Cultural. Curitiba, 1984. 
MANO, M. Os Campos De Araraquara: Um estudo de história indígena no interior paulista. Tese (Doutorado). IFCH/UNICAMP. Campinas, 2006

MANO, M. A Cerâmica e os Rituais Funerários: xamanismo, antropofagia e guerra entre os Tupi-Guarani. Interações - Cultura e Comunidade. V. 5 n. 5. 2009. (P. 111-128).

MARANCA, S. Relatório das atividades do quarto e quinto ano do Pronapa no Estado de São Paulo. In: Programa Nacional de Pesquisas Arqueológicas V, Resultados preliminares do quinto ano (1969.70). Publicações Avulsas, Museu Paraense Emílio Goeldi. Belém, 1974. (P. 117-126).

MARANCA, S; SILVA, A.L.M.; SCABELLO, A.M.P. Projeto Oeste Paulista de Arqueologia do Baixo e Médio Vale do Rio Tietê: síntese dos trabalhos realizados. Revista do museu de Arqueologia e Etnologia n. 4. São Paulo, 1994.

MAROIS, R.; SCATAMACCHIA, M.C.M.; SERRANO, E.D. Ensaio sobre a composição das decorações. Instituto Panamericano de Geografia e História. México, 1994.

MEGGERS, B.; EVANS, C. Como interpretar a linguagem cerâmica. Smithsonian Institution. Washington, 1970

MELIÁ, B. A experiência religiosa guarani. In: MARZAL, Manuel (coord.). O rosto índio de Deus. Vozes. São Paulo, 1989.

MENDONÇA, A. S. História da Arqueologia Brasileira. Pesquisas, Antropologia, 46. 1991.

MILLER, T. O. Arqueologia da Região Central do Estado de São Paulo. Dédalo 8(18). São Paulo, 1972.

MINDLIN, B. $O$ fogo e as chamas dos mitos. Estudos Avançados n. 44, 2002

MONTEIRO, J M. Negros da Terra: Índios e Bandeirantes nas Origens de São Paulo. São Paulo, Companhia das Letras 1994.

MONTEIRO, J M. Tupis, Tapuias e historiadores: Estudos de História Indígena e do Indigenismo. Tese de Livre Docência. UNICAMP. Campinas, 2001

MONTICELLI, G. Vasilhas de cerâmica Guarani: resgate da memória entre os Mbyá. Dissertação (Mestrado) - PUCRS, Porto Alegre, 1995.

MONTOYA, A. R. Conquista Espiritual Hecha por los Religiosos de la Compañia de Jesús em las Provincias del Paraguay, Paraná, Uruguay y Tape. Martins Livreiro. Porto Alegre, 1985.

MONTOYA, A. $R$ Vocabulario y Tesoro de la lengua guarani ó más bien tupi. Viena/Paris, 1976.

MORAES, C. A. Arqueologia Tupi no Nordeste de São Paulo: um estudo de variabilidade artefatual. Dissertação de Mestrado. Museu de Arqueologia e Etnologia da Universidade de São Paulo. São Paulo, 2007 
MORAES, C. A. A cerâmica arqueológica brasileira: definições e princípios de análise. Apostila Curso de Análise Cerâmica. II Simpósio Jauense de Arqueologia. Prefeitura Municpal de Jaú. Jaú - SP, 2006.

MORAIS, J. L. Projeto Paranapanema: avaliação e perspectiva. Revista de Antropologia da Universidade de São Paulo. V. 24. São Paulo, 1981.

MORAIS, J. L. Projeto Paranapanema: avaliação e perspectiva. Revista do Museu Paulista, V. 24 São Paulo, 1994.

MORAIS, J. L. Salvamento Arqueológico na área de influência da PCH MojiGuaçu. Revista do Museu de Arqueologia e Etnologia, n. 5. São Paulo, 1995. (P. 77-98).

MORAIS, J. L. Perspectivas geoambientais da arqueologia do Paranapanema paulista. Tese de Livre-Docência MAE/USP. São Paulo, 1999.

MORAIS, J. L. Resgate arqueológico na área de influência da duplicação das rodovias SP342 e SP346: preservação do patrimônio dos sítios Ipê e Mota Pais. Relatório Técnico Científico Final. São Paulo, 2002

MORALES, W. F. MOI, F. P. Índios e Africanos no interior paulista: um estudo sobre a transição do cativeiro indígena para a escravidão africana na Vila de Jundiaí, SP, no século XVIII. Revista do Museu de Arqueologia e Etnologia. São Paulo, 2008

MÜLLER, R. P. Tayngava, a noção de representação na arte gráfica Asurini do Xingu. In: VIDAL, L. (Org.) Grafismo Indígena: estudos de antropologia estética. Edusp. São Paulo, 1992.

MYASAKI, N. AYTAI, D. A aldeia pré-histórica de Monte Mor. Publicaçãp Avulsa da Pontifícia Universidade Catórlica de Campinas. Campinas, 1974.

NETTO, L. Archivos do Museu Nacional. Rio de Janeiro: v. VI, 1885.

NEUMANN, Mariana Araújo. Ñande Rekó: diferentes jeitos de ser Guarani. Dissertação de Mestrado apresentada ao Programa de Pós-graduação em História da Universidade Federal do rio Grande do Sul. Porto Alegre, 2008.

NIMUENDAJU, C. U. As lendas de criação e destruição do mundo como fundamentos da religião dos Apapocúva-Guarani. Tradução Charlotte Emmerich e Eduardo Viveiros de Castro. HUCITEC-EDUSP. São Paulo, 1987.

NOELLI, F. S. Sem Tekohá não há Tekó. Em busca de um modelo etnoarqueológico da aldeia de subsistência guarani e sua aplicação a uma área de domínio do Delta do Jacuí. Dissertação (Mestrado) - PUC-RS. Porto Alegre, 1993.

NOELLI, F. S. As hipóteses sobre o centro de origem e rotas de expansão dos Tupi. Revista de Antropologia FFLCH/USP. V. 39 N. 2. São Paulo, 1996.

OLIVEIRA, K. Estudando a cerâmica pintada da tradição Tupiguarani: a coleção Itapiranga, Santa Catarina. Dissertação de Mestrado. Pontíficia Universidade Católica do Rio Grande do Sul. Porto Alegre, 2008.

OLIVEIRA, E. Potes que encantam: estilo e agência na cerâmica policroma da Amazônia. Dissertação MAE/USP. São Paulo, 2016 
ORTON, C.; TYERS, P.; VINCE, A. Pottery in Archaeology. Cambridge Manuals in Archaeology. Cambridge University Press, Cambridge, 1997.

PALLESTRINI, L. Interpretações das estruturas arqueológicas em sítios do Estado de São Paulo. Tese de Livre Docência, FFLCH/USP. São Paulo, 1975.

PALLESTRINI, L. Achados de aldeias pré-históricas no vale do Paranapanema. Revista de Atualidade Indígena, ano I, n. 4. Brasília, 1977. (P. 34-39).

PANACHUK, L. Fragmentos da tradição arqueológica Tupiguarani (Minas Gerais/Brasil). Monografia (Graduação em Ciências Sociais) - Faculdade de Filosofia e Ciências Humanas, Universidade Federal de Minas Gerais, Belo Horizonte, 2004.

PEREIRA JÚNIOR, J. A. Contribuição para o estudo da arqueologia do extremo norte paulista. Revista do Instituto Histórico e Geográfico, x. LIV. São Paulo, 1957. (P. 313-357).

PEREIRA JÚNIOR, J. A. Cerâmica Indígena do Morumbi. Apontamentos Arqueológicos, n. 6. São Paulo, 1964a

PEREIRA JÚNIOR, J. A. Notícia sobre um achado arqueológico ocorrido em Itapeva (Faxina) (Estado de São Paulo). Apontamentos Arqueológicos, n. 7. São Paulo, 1964b.

PEREIRA JÚNIOR, J. A. Cerâmica Arqueológica, Indígena, de Peruíbe (Litoral do Estado de São Paulo) (Primeiras Informações). Apontamentos Arqueológicos, n. 8. São Paulo, 1965.

PEIRCE, C. S. Semiótica. Tradução de José Teixeira Coellho Neto. 3. ed. Perspectiva. São Paulo, 2003.

PRICE, S. Arte Primitiva em Centros Civilizados. Tradução de Inês Alfano. Editora UFRJ. Rio de Janeiro, 2000.

PRONAPA. Arqueologia Brasileira em 1968. Museu Paraense Emílio Goeldi. Belém, 1969.

PROUS, A. A Arqueologia Brasileira. Editora da Universidade de Brasília. Brasília, 1992.

PROUS, A. A pintura em cerâmica Tupiguarani. In: Ciência Hoje, 213, 2005.

PROUS, A. A pintura tupiguarani em cerâmica. Revista do Museu de Arqueologia e Etnologia, São Paulo, Suplemento 8, 2009. (P. 11-20)

PROUS, A. Arte Pré-histórica do Brasil. Editora com Arte. Belo Horizonte, 2011.

QUEIROZ, C. M.; BORNAL, W. G. Salvamento Arqueológico Sítio Caninhas. Canas - SP, 2002.

RIBEIRO, B. A linguagem Simbólica na cultura material: Introdução. In.: RIBEIRO, B. (Cord.) Suma etnológica brasileira. Edição utilizada do Handbook of South american indians. Volume 3. Arte Indígena. FINEP $2^{\text {a }}$ Edição. Petrópolis, 1987a. 
RIBEIRO, B. Desenhos semânticos e identidade étnica: o caso Kayabí. In.: RIBEIRO, B. (Cord.) Suma etnológica brasileira. Edição utilizada do Handbook of South american indians. Volume 3. Arte Indígena. FINEP 2a Edição. Petrópolis, 1987b.

RIBEIRO, L. B. Limpando Ossos e Expulsando Mortos: estudo comparativo de rituais funerários em culturas indígenas brasileiras através de uma revisão bibliográfica. Dissertação de Mestrado em Antropologia Social. UFSC. Florianópolis, 2002.

RICE, P. Pottery Analysis: a source book. Chicago University Press. Chicago, 1987.

RODRIGUES, R. A. A Cenários da ocupação Guarani na calha do alto Paraná: um estudo etnoarqueológico. Dissertação de Mestrado. MAE/USP. São Paulo, 2001.

RODRIGUES, R. A. Ocupação Guarani na Calha do Alto Paraná: Dados Preliminares Para Futuras Interpretações. Revista Topos, v. 2 n. 2. São Paulo, 2008. (P. 113-152)

RODRIGUES, R. A. Diagnóstico Arqueológico Para Licenciamento Ambiental: relatório de avaliação e caracterização da situação atual na área do loteamento Parque Itaici, município de Indaiatuba (SP). Novembro, 2012.

RODRIGUES, R. A. (Org.) Programa de Gestão do patrimônio Arqueológico Área do Sistema de Transmissão de Energia Mata de Santa Genebra Entre os Estados de São Paulo e Paraná. Relatório 01: Diagnóstico dos Bens Culturais. Fundação Araporã. Araraquara, 2014.

ROE, P. G. Style, Society, Myth and Structure. In: CARR; NEITZEL. Style, Society and Person. Archaeological and Ethnological Perspective. New York, Plenum, 1995.

RYE, O.S. Pottery Technology. Principles and reconstruccion. Manual of Archaeology 4. Insmithsonian Institute. Whasington, 1981.

SALLUM, M. Estudo do gesto em material cerâmico do spitio Gramado Município de Brotas / São Paulo. Dissertação de Mestrado MAE/USP. São Paulo, 2011,

SANABRIA, I. S. B. Paulo Duarte e a Construção do Patrimônio Plural - a Inclusão de Outras Memórias no Conceito de Patrimônio Brasileiro. Anais do XXVI Simpósio Nacional de História - ANPUH. São Paulo, julho 2011.

SCATAMACCHIA, M. C. M. Tentativa de caracterização da Tradição Tupiguarani. Dissertação de Mestrado, FFLCH/USP. São Paulo, 1981.

SCATAMACCHIA, M. C. M. A tradição policrômica no leste da América do Sul evidenciada pela ocupação guarani e tupinambá: fontes arqueológicas e eteno-históricas. Tese de Doutorado, FFLCH/USP. São Paulo, 1990. 
SCATAMACCHIA, M. C. M. Proposta de terminologia para a descrição e classificação da cerâmica arqueológica dos grupos pertencentes à família linguística Tupi-Guarani. Revista do Museu de Arqueologia e Etnologia n. 14. São Paulo, 2004.

SCATAMACCHIA, M. C. M. Considerações sobre a distribuição das sociedades tribais de filiação linguística Tupi-Guarani no estado de São Paulo. Os Ceramistas Tupi-Guarani. V. 1. Sigma. Belo Horizonte, 2008.

SCHADEM, E. Aspectos Fundamentais da Cultura Guarani. Difusão Europeia do Livro. São Paulo, 1962.

SCHAN, D. P. A Linguagem Iconográfica da Cerâmica Marajoara. Dissertação (Mestrado) - PUCRS. Porto Alegre, 1996.

SCHIAVETTO, S. N. O. A Arqueologia Guarani: construção e desconstrução da identidade indígena. FAPESP. Annablume. São Paulo, 2003.

SCHIAVETTO, S. N. O. Arqueologia Regional e Educação: propostas de estudos sobre um "passado excluído" de Araraquara/SP. Tese de Doutorado. IFCH/UNICAMP. Campinas, 2007.

SETTON M. G. J. A teoria do habitus em Pierre Bourdieu: uma leitura contemporânea. Revista Brasileira de Educação. № 20 Maio/Jun/Jul/Ago 2002.

SHANKS, M. Post- Processual Archaeology and After. In: CHIPPINDALE, C.; MASCHNER, $\mathrm{H}$. (Eds). Handbook of Archaelogical Methods and Theories. New York, 2005. P. 133-144.

SHANKS \& TILLEY Social Theory and Archaeology. Oxforf. Polity Press, 1987.

SHANKS \& TILLEY Re-Constructing Arqchaeology. Routledge. London, 1996.

SHEPARD, A. Ceramics for the Archaeologist. Carnegie Institution of Washington. Washington, 1971.

SILVA, F. A. Etnoarqueologia: Uma perspectiva arqueológica para 0 estudo da cultura material. Revista Métis: história \& cultura - vol.8 n.16, p.121-139, jul/dez, 2009.

SILVA, S. B. Etnoarqueologia dos Grafismos Kaingang: um modelo para a compreensão das sociedades Proto-Jê Meridionais. Tese de Doutorado em Antropologia. PPGAS/USP. São Paulo, 2001.

SINÓPOLI, C.A. Approaches to archaeological ceramics. Plenum Press. New York and London, 1991.

SKIBO, J. Pottery and Function: a use-alternation perspective. Plenum Press. New York, 1992. 
SOARES, A. L. R. Contribuição à Arqueologia Guarani: estudo do sítio Ropke. Tese de doutorado. Museu de Arqueologia e Etnologia da Universidade de São Paulo. São Paulo, 2004.

STADEN, H. Duas Viagens ao Brasil: Primeiros registros sobre o Brasil. Tradução de Angel Bojadsen. L\&PM Pocket. Porto Alegre, 2011.

TAUNAY, A.D. História das Bandeiras Paulistas. Centro de Documentação do Conhecimento Brasileiro. 2012.

THOMAZ, R.C.C. Arqueologia da influência jesuítica no Baixo Paranapanema: um estudo do sítio Taquaruçu. Dissertação de Mestrado FFLCH/USP. São Paulo, 1995.

TOCHETTO, F. B. Possibilidades de Interpretação do Conteúdo Simbólico da Arte Gráfica Guarani. Revista do Museu de Arqueologia e Etnologia. N.6. São Paulo, 1996. (P. 34-45)

VARELA, A. G. Atividades científicas na "Bela e Bárbara" capitania de São Paulo (1796-1823). Annablume. São Paulo, 2009.

VIDAL, L.; SILVA, F. A. Antropologia Estética: enfoques teóricos e contribuições metodológicas. In: VIDAL, L. (Org.) Grafismo Indígena: estudos de antropologia estética. Edusp. São Paulo, 1992.

ZANETTINI ARQUEOLOGIA. Programa de Resgate Arqueológico Empreendimento Ponte de Concreto sobre o rio Mogi-Guaçú - Cacheira de Emas, Município de Pirassunuinga, São Paulo. Relatório Final. São Paulo, 2006.

ZANETTINI ARQUITETURA. Sítio Santa Marina. Relatório Final de Atividades de Salvamento Jacareí-SP, 1998.

WIESSNER, P. Style and Social Information in Kalahari San Projectile Points. American Antiquity, Vol. 48, No. 2. 1983. p. 253-276.

WOLF, Eric R. Europa y La gente sin história. México DF: FCE, 2005. 
Anexo 1: Ficha de análise 
ANÁLISE CERÂMICA TUPI

\begin{tabular}{|c|c|c|c|c|c|c|c|c|c|c|c|c|c|c|c|c|c|c|c|c|c|c|c|c|}
\hline \multicolumn{5}{|c|}{ DADOS GERAIS } & \multicolumn{7}{|c|}{ PRODUÇÃO } & \multicolumn{10}{|c|}{ MORFOLOGIA } & \multirow[b]{2}{*}{ 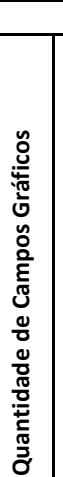 } & \multirow[b]{2}{*}{ 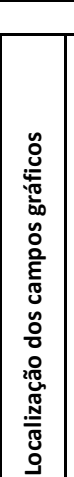 } & \multirow[b]{2}{*}{ 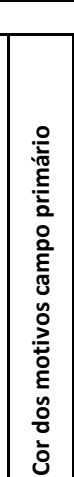 } \\
\hline 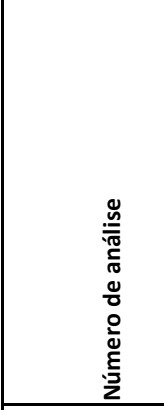 & 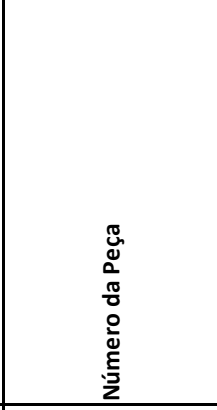 & 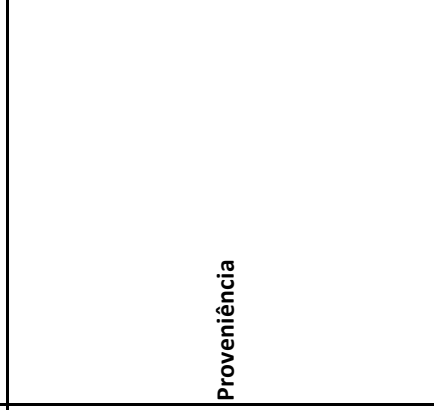 & 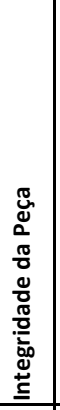 & 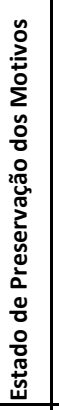 & 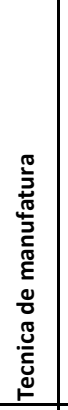 & 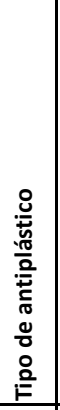 & 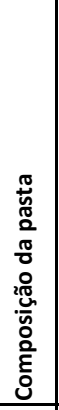 & 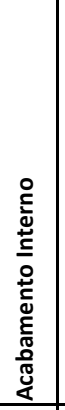 & 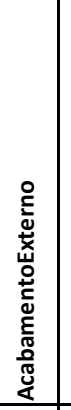 & 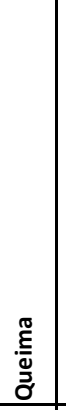 & 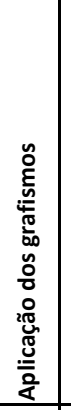 & 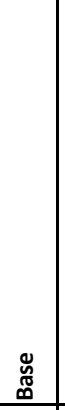 & $\begin{array}{l}\frac{\pi}{0} \\
\\
\\
\end{array}$ & 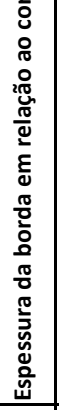 & 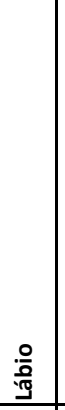 & 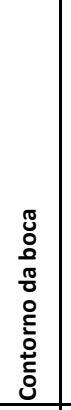 & $\begin{array}{l}0 \\
\stackrel{0}{0} \\
\stackrel{0}{0} \\
\end{array}$ & 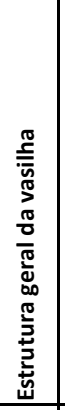 & 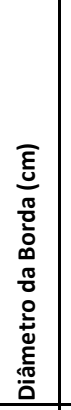 & 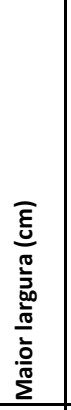 & 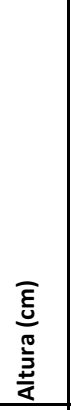 & & & \\
\hline MHS-01 & $\mathrm{SN}$ & Capela do Alto (Bairro do Porto) & 1 & 3 & 1 & 5 & 1 & 1 & 5 资 & 99 & $3 \mid$ & 1 & 99 & 1 & 99 & 1 & 2 & 1 & 48 & 95 & 78 & 3 & 2 & 2 \\
\hline MHS-02 & $\mathrm{SN}$ & Iperó (Bairro Cerrado) & 1 & 3 & 1 & 5 & 1 & 1 & 5 & 4 & 3 & 1 & 99 & 1 & 99 & 1 & 2 & 1 & 41 & 105 & 59 & 3 & 2 & 2 \\
\hline MHS-03 & SN & Iperó (Sítio Iperó) & 1 & 1 & 1 & 5 & 2 & 5 & 5 & 4 & 2 & 3 & 1 & 2 & 1 & 4 & 1 & 3 & 43 & 46 & 12 & 4 & 1 & 3 \\
\hline MHS-04 & SN & Sarapuí & 2 & 1 & 1 & 5 & 1 & 1 & 5 & 4 & 3 & 1 & 2 & 1 & 1 & 1 & 2 & 2 & 31 & 31 & 13 & 1 & 2 & 2 \\
\hline MHS-05 & SN & Sarapuí & 3 & 1 & 1 & 5 & 1 & 1 & 5 & 4 & 3 & 99 & 2 & 1 & 1 & 1 & 2 & 2 & 30 & 30 & 13 & 1 & 2 & 2 \\
\hline MHS-06 & $S N$ & Iperó & 3 & 3 & 1 & 5 & 1 & 2 & 5 - & 5 & 3 & 99 & 99 & 1 & 99 & 1 & 2 & 1 & \begin{tabular}{l|l}
99 \\
\end{tabular} & 99 & 99 & 2 & 2 & 99 \\
\hline MCS-01 & $\mathrm{SN}$ & Salto & 1 & 3 & 1 & 5 & 2 & 2 & 5 & 1 & $3 \mid$ & 1 & 99 & 1 & 99 & 1 & 2 & 1 & 34 & 88 & 88 & 3 & 2 & 2 \\
\hline \begin{tabular}{|l|} 
MNSA-01 \\
\end{tabular} & MNSA 185 & Aparecida & 1 & 2 & 1 & 5 & 1 & 5 & 1 & 7 & 2 & 3 & 4 & 2 & 1 & 1 & 1 & 3 & 51 & 51 & 14 & 3 & 1 & 2 \\
\hline \begin{tabular}{|l|} 
MNSA-02 \\
\end{tabular} & ARQ 02004 & Aparecida & 1 & 3 & 1 & 5 & 1 & 5 & $1 \mid$ & 7 & 2 & 1 & $4 \mid$ & 4 & 3 & 1 & 1 & 3 & \begin{tabular}{l|l}
34 & \\
\end{tabular} & 34 & 12 & 2 & 1 & 99 \\
\hline \begin{tabular}{|l|} 
MNSA-03 \\
\end{tabular} & ARQ 02003 & Aparecida & 1 & 3 & 1 & 5 & 1 & 5 & $1 \mid$ & $4 \mid$ & 2 & 3 & $4 \mid$ & 2 & 1 & 1 & 1 & 3 & 36 & 37 & 12.5 & 4 & 1 & 3 \\
\hline \begin{tabular}{|l|} 
MNSA-04 \\
\end{tabular} & ARQ 02005 & Aparecida & 1 & 1 & 1 & 5 & 1 & 5 & 5 & 7 & 2 & 1 & 1 & 1 & 3 & 2 & 1 & 3 & 32.5 & 33 & 10 & 2 & 1 & 3 \\
\hline CEMAARQ-01 & $\begin{array}{l}\text { MDG 082, 088, } \\
090,101,102,104\end{array}$ & Presidente Prudente (sítio Mandaguari) & 2 & 1 & 1 & 5 & 2 & 4 & 7 & 7 & 2 & 1 & 6 & 1 & 2 & 1 & 2 & 1 & 31] & 59 & 60 & 3 & 2 & 3 \\
\hline CEMAARQ-02 & $\begin{array}{l}\text { MDG 02, 08, 11, } \\
\text { O78, 107, 107, } \\
110, \text { SN }\end{array}$ & Presidente Prudente (sítio Mandaguari) & 2 & 2 & 1 & 5 & 2 & 1 & 5 & 7 & 3 & 1 & 6 & 1 & 2 & 1 & 3 & 1 & 45 & 74 & 99 & 4 & 2 & 1 \\
\hline CEMAARQ-03 & \begin{tabular}{|l} 
MDG $48,52,73$ \\
$80,81,85,89$ \\
$108, S N$, SN \\
\end{tabular} & Presidente Prudente (s & 2 & 1 & 1 & 5 & 3 & 1 & 7 & 4 & 2 & 1 & 99 & 1 & 99 & 1 & 2 & 1 & 99 & 58 & 51 & 2 & 2 & 1 \\
\hline CEMAARQ-04 & $\begin{array}{l}\text { MDG 93,100, SN, } \\
\text { SN, SN }\end{array}$ & Presidente Prudente (sítio M & 2 & 2 & 1 & 5 & 2 & 5 & 5 & 7 & 2 & 99 & 2 & 1 & 2 & 1 & 2 & 1 & 47 & 75 & 50 & 2 & 2 & 3 \\
\hline CEMAARQ-05 & SN & $\begin{array}{l}\text { Presidente Epitácio (sítio Lagoa São } \\
\text { Paulo II) }\end{array}$ & 1 & 2 & 1 & 5 & 2 & 1 & 5 & 99 & 3 & 1 & 3 & 1 & 2 & 1 & 2 & 2 & 40 & 41 & 16.5 & 1 & 2 & 2 \\
\hline CEMAARQ-06 & GVA 217 & Rosana (sítio Gavião) & 1 & 2 & 1 & 5 & 99 & 5 & 5 & 7 & 2 & 1 & 1 & 2 & 1 & 1 & 1 & 2 & 23 & 23 & 15 & 2 & 2 & 1 \\
\hline CEMAARQ-07 & SN & Presidente Prudente (sítio Mandaguari) & 1 & 1] & 1 & 1 & 1 & 1] & 5[ & 7| & 2 & 1] & 2 & 1 & $2 \mid$ & 1] & 2 & 2 & 28. & 32 & 13.5 & 2 & 2 & 3 \\
\hline
\end{tabular}




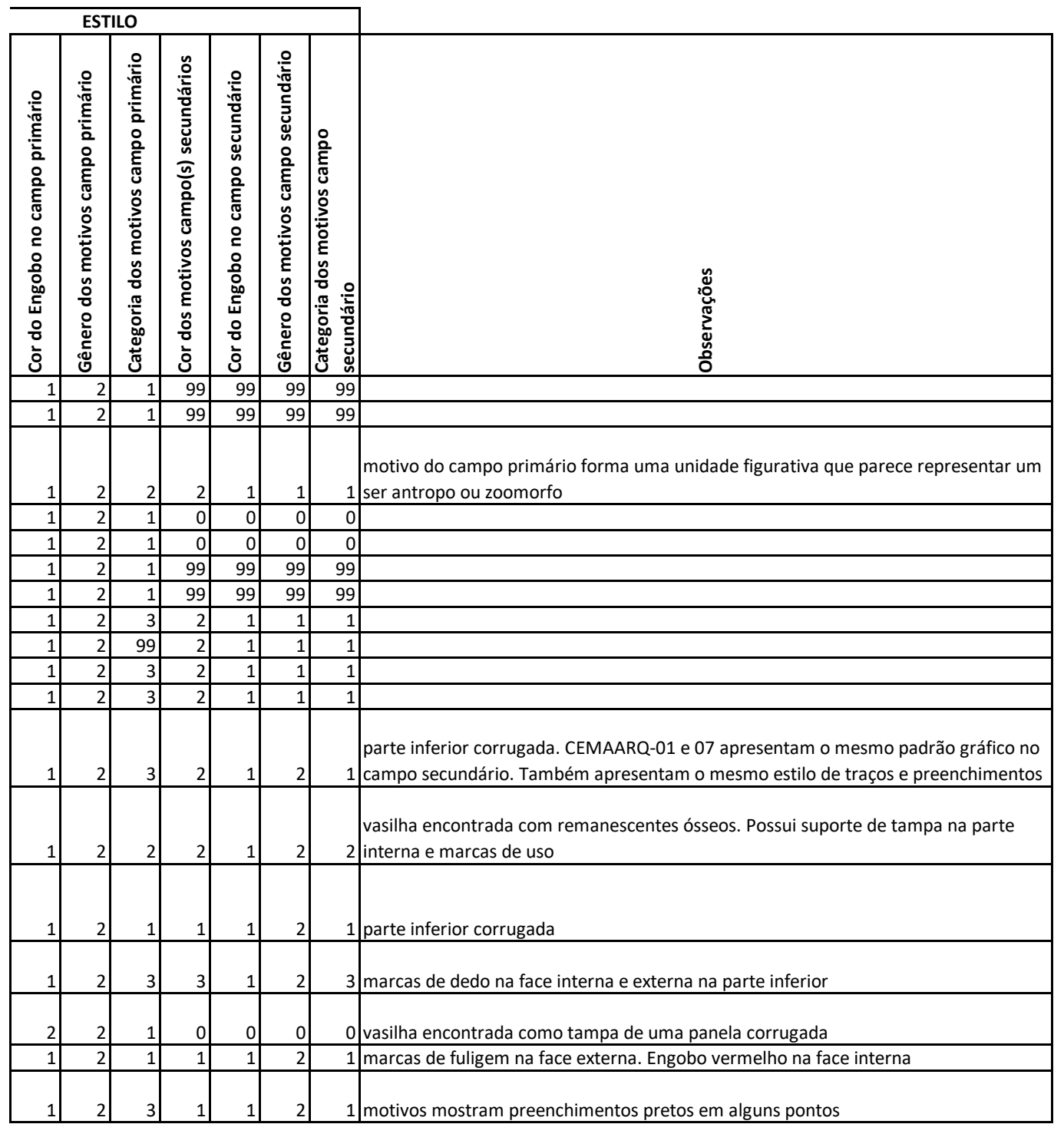




\begin{tabular}{|c|c|c|c|c|c|c|c|c|c|c|c|c|c|c|c|c|c|c|c|c|c|c|c|c|}
\hline CEMAARQ-08 & $\mathrm{SN}$ & Rosana (sítio Gavião) & 1 & 3 & 1 & 5 & 1 & 5 & 5 & 7 & 2 & 1 & 3 & 1 & 3 & 1 & 2 & 2 & 34 & 35 & 12 & $3 \mid$ & 1 & 99 \\
\hline CEMAARQ-09 & SN & Rosana (sítio Gavião) & 3 & 1 & 1 & 5 & 1 & 1 & 5 & 7 & 2 & 1 & 2 & 1 & 2 & 1 & 2 & 2 & 39 & 50 & 20 & 2 & 2 & 2 \\
\hline CEMAARQ-10 & $\mathrm{SN}$ & $\begin{array}{l}\text { Presidente Epitácio (sítio Lagoa São } \\
\text { Paulo II) }\end{array}$ & 1 & 1 & 1 & 5 & 2 & 1 & 5 & 5 & 3 & 3 & 2 & 1 & 2 & 1 & 2 & 1 & 42 & 68 & 57 & 2 & 2 & 1 \\
\hline CEMAARQ-11 & $\mathrm{SN}$ & Rosana (sítio Tuiuiu) & 1 & 3 & 1 & 5 & 1 & 1 & $7 \mid$ & $7 \mid$ & 3 . & 3 & 99 & 1 & 99 & 1 & 3 & 1 & 41 & 65 & 45 & 2 & 2 2 & 1 \\
\hline CEMAARQ-12 & SCB 353 & Presidente Prudente & 1 & 3 & 1 & 5 & 2 & 2 & 5 & 2 & 3 & 99 & 4 & 2 & 2 & 1 & 3 & 1 & 32 & 56 & 99 & 3 & 2 & 1 \\
\hline CEMAARQ-13 & MDG 087 & Presidente Prudente (sítio Mandaguari) & 3 & 2 & 1 & 5 & 1 & 5 & 5 & 1 & 2 & 1 & 1 & 1 & 2 & 1 & 2 & 2 & 42 & 99 & 14 & 2 & 1 & 3 \\
\hline CEMAARQ-14 & $\begin{array}{l}\text { MDG 2540, 2541, } \\
2544,2553,2554 \\
2555,2556\end{array}$ & $\begin{array}{l}\text { Presidente Epitácio (sítio Lagoa São } \\
\text { Paulo II) }\end{array}$ & 3 & 1 & 1 & 5 & 2 & 5 & 5 & 2 & 2 & 99 & 1 & 1 & 3 & 1 & 2 & 2 & 36 & 99 & 19 & 3 & 1 & 3 \\
\hline MAR-01 & SN & Pirapozinho (Sítio Alvin) & 3 & 1 & 1 & 5 & 1 & 1 & 5 & 7 & 2 & 99 & 2 & 2 & 2 & 1 & 2 & 2 & 37 & 99 & 99 & 2 & 2 & 2 \\
\hline MAR-02 & $\mathrm{SN}$ & lepê (Sítio Lagoa Seca) & 3 & 2 & 1 & $5 \mid$ & 2 & 5 & 1 & $7 \mid$ & $2 \mid$ & 1 & $3 \mid$ & 1 & 2 & 1 & 1 & 3 & 32 & 32 & 15 & 1 & 1 & 3 \\
\hline MAR-03 & PRN-615 & Euclides da Cunha (Sítio Lopes) & 1 & 1 & 1 & 5 & 1 & 5 & 5 & 7 & 2 & 1 & 3 & 1 & 2 & 1 & 2 & 2 & 23 & 27 & 12 & 1 & 1 & 2 \\
\hline MAR-04 & SN & lepê (Sítio Pernilongo) & 1 & 1 & 1 & 5 & 1 & 1 & \begin{tabular}{l|l}
5 & $-12-10$ \\
\end{tabular} & $7 \mid$ & $2 \mid$ & 1 & $3 \mid$ & 1 & 2 & 1 & 2 & 2 & 32 & 38 & 14 & 1 1 & 2 & 2 \\
\hline MAR-06 & SN & lepê (Sítio Pernilongo) & 1 & 3 & 1 & 5 & 3 & 5 & 5 & 99 & 2 & 1 & 1 & 1 & 2 & 1 & 2 & 2 & 25 & 30 & 15 & 1 & 2 & 99 \\
\hline MAR-07 & SN & Rosana & 1 & 2 & 1 & 5 & 2 & 5 & 5 & 7 & 2 & 1 & 4 & 1 & 2 & 1 & 3 & 1 & 31 & 62 & 44 & 2 & 2 & 1 \\
\hline MAI-01 & SN & Iepê (Sítio Aguinha) & 1 & 2 & 1 & 5 & 2 & 1 & \begin{tabular}{l|l}
5 & \\
\end{tabular} & $7 \mid$ & \begin{tabular}{l|l}
3 & \\
\end{tabular} & 1 & 99 & \begin{tabular}{l|l|l|}
99 & \\
\end{tabular} & 99 & 1 & 2 & 1 & 99 & 116 & 56 & 2 & 2 & 1 \\
\hline MAI-02 & SN & lepê (Sítio Aguinha) & 2 & 2 & 1 & 5 & 2 & 1 & 5 & 5 & 3 & 1 & 99 & \begin{tabular}{|c|c|}
99 \\
\end{tabular} & 99 & 1 & 2 & 1 & 99 & 44 & 37 & 2 & 2 & 1 \\
\hline MAI-04 & SN & lepê (Sítio Pernilongo) & 2 & 3 & 1 & 5 & 2 & 1 & 5 & 3 & 3 & 1 & \begin{tabular}{l|l}
99 \\
\end{tabular} & \begin{tabular}{l|l}
99 \\
\end{tabular} & 99 & 1 & 2 & 1 & 39 & 71 & 49 & 2 & 2 & 1 \\
\hline CRAA-01 & ALV 01 & Piraju (Sítio Alvin) & 1 & 2 & 1 & 5 & 3 & 1 & 5 & 7 & 3 & 1 & 4 & 1 & 2 & 1 & 2 & 1 & 60 & 98 & 73 & 4 & 2 & 1 \\
\hline CRAA-02 & 003-459 & Piraju (Sítio Alvin) & 1 & 1 & 1 & 99 & 99 & 5 & 5 & 99 & 2 & 1 & 3 & 1 & 2 & 1 & 2 & 2 & 34 & 37 & 15 & 1 & 2 & 2 \\
\hline CRAA-03 & $\mathrm{SN}$ & Piraju (Sítio Alvin) & 1 & 3 & 1 & 99 & 99 & 5 & \begin{tabular}{l|l}
5 & \\
\end{tabular} & \begin{tabular}{l|l}
99 \\
\end{tabular} & 2 & 1 & 1 & \begin{tabular}{l|l}
3 \\
\end{tabular} & 2 & 1 & 2 & 2 & 30 & 35 & 13 & 1 & 2 & 1 \\
\hline CRAA-04 & SN & lepê (Sítio Pernilongo) & 1 & 2 & 1 & 5 & 2 & 5 & 5 & 7 & $2 \mid$ & 1 & $2 \mid$ & 1 & 3 & 1 & 2 & 2 & 42 & 47 & 18 & 2 & 1 & 3 \\
\hline FCJ-01 & SP-CA-01-12 a 23 & Canas & 1 & 3 & 1 & 5 & 3 & 5 & 5 & 7 & 2 & 3 & 1 & 4 & 3 & 3 & 1 & 3 & 33 & 33 & 11 & 2 & 1 & 2 \\
\hline $\mathrm{FCJ}-02$ & SP-CA-01-24 & Canas & 1 & 2 & 1 & 5 & 3 & 5 & 1 & \begin{tabular}{l|l}
99 \\
\end{tabular} & 2 & 3 & 1 & 4 & 3 & 3 & 1 & $3: 2$ & 22.5 & 23 & 6 & 2 & 1 & 2 \\
\hline $\mathrm{FCJ}-03$ & SP-CA-01-461 a 468 & Canas & 1 & 2 & 1 & 5 & 2 & 5 & 5 & 7 & 2 & 3 & 1 & 4 & 1 & 2 & 1 & 3 & 26 & 26 & 8 & 2 & 1 & 2 \\
\hline $\mathrm{FCJ}-04$ & \begin{tabular}{|l|} 
SP-CA-01-406, 409 \\
a 420,434 a 437 \\
440 \\
\end{tabular} & Canas & 1 & 2 & 1 & 5 & 3 & 5 & 1 & 7 & 2 & 3 & 1 & 4 & 1 & 3 & 1 & 3 & 53 & 53 & 12 & 2 & 1 & 2 \\
\hline FCJ-05 & $\begin{array}{l}\text { SP-CA-01-01 a 10, } \\
58,59,62\end{array}$ & Canas & 1 & 3 & 1 & 6 & 3 & 5 & 5 & 7 & 2 & 3 & 1 & 4 & 3 & 1 & 1 & 3 & 48 & 48 & 14 & 2 & 1 & 2 \\
\hline FCJ-06 & $\begin{array}{l}\text { SP-CA-01-25 a } 28, \\
30 \text { a } 35,38\end{array}$ & Canas & 1 & 2 & 1 & 2 & 3 & 5 & 5 & 99 & 2 & 3 & 1 & 4 & 1 & 3 & 1 & 3 & 48 & 48 & 15 & 2 & 1 & 2 \\
\hline $\mathrm{FCJ}-07$ & \begin{tabular}{|l|} 
SP-CA-01-415, 419, \\
469 a 486
\end{tabular} & Canas & 1 & 2 & 1 & 5 & 3 & 5 & 5 & 7 & 2 & 3 & 1 & 4 & 1 & 1 & 1 & 3 & 42.5 & 42.5 & 11 & 2 & 1 & 2 \\
\hline FCJ-08 & SP-CA-01-39 a 56 & Canas & 2 & 2 & 1 & 6 & 2 & 5 & 1 & 7 & 2 & 3 | & 1 & 4 & 3 & 3 & 1 & \begin{tabular}{c|c}
3 \\
\end{tabular} & 34 & 34 & 11 & 2 & 1 & 2 \\
\hline FCJ-09 & SP-CA-01-68 a 75 & Canas & 1 & 1 & 1 & 5 & 1 & 5 & 5 & $7 \mid$ & 2 & 3 & 1 & 4 & 1 & 1 & 1 & 3 & 54 & 54 & 16 & 3 & 1 & 2 \\
\hline FCJ-10 & SP-CA-01-928 a 950 & Canas & 1 & 2 & 1 & 5 & 1 & 5 & 1 & 7 & 2 & 1 & 1 & 4 & 1 & 2 & 1 & 3 & 29 & 29 & 8.5 & 2 & 1 & 2 \\
\hline
\end{tabular}




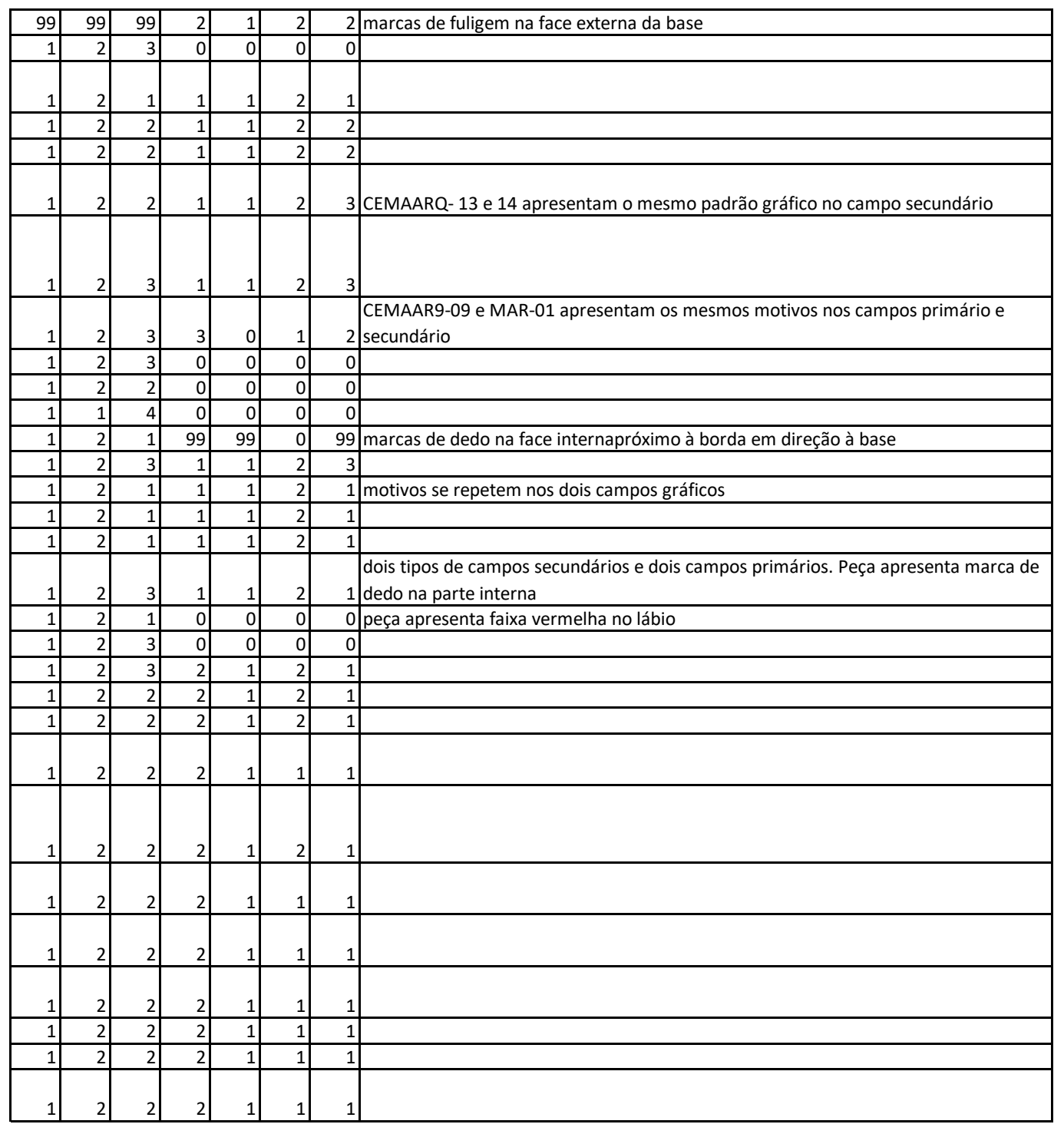




\begin{tabular}{|c|c|c|c|c|c|c|c|c|c|c|c|c|c|c|c|c|c|c|c|c|c|c|c|c|}
\hline FCJ-11 & \begin{tabular}{|l} 
SP-CA-01- 631, 768 \\
a 771, 773, 774, \\
779 a 797, 800, \\
801 \\
\end{tabular} & Canas & 2 & 3 & 1 & 5 & 2 & 5 & 5 & 7 & 2 & 99 & 6 & 1 & 1 & 1 & 1 & 3 & 50 & 50 & 14.5 & 4 & 1 & 2 \\
\hline FCJ-12 & SN & Jacareí & 1 & 3 & 1 & 1 & 3 & 5 & 1 & 99 & 2 & 1 & 6 & 1 & 1 & 1 & 1 & 3 & 41 & 41 & 13 & 2 & 1 & 2 \\
\hline MMEA-01 & MM286-1989 & Monte Mor & 1 & 3 & 1 & 5 & 1 & 5 & 5 & 7 & 99 & 3 & 6 - & 1 & 1 & 1 & 1 & 3 & 35 & 35 & 9 & 3 & 1 & 99 \\
\hline MMEA-02 & SN & Monte Mor (Sítio Roger Maluf) & 3 & 3 & 1 & 5 & 3 & 5 & 5 & 7 & 2 & 1 & 6 & 1 & 1 & 1 & 1 & 3 & 56 & 56 & 15 & 2 & 1 & 99 \\
\hline MMMG & 810 & Mogi Guaçu & 2 & 2 & 1 & 5 & 1 & 1 & 5 & 7 & 2 & 1 & 3 & 1 & 2 & 1 & 2 & 1 & 99 & 75 & 63 & 3 & 2 & 2 \\
\hline
\end{tabular}




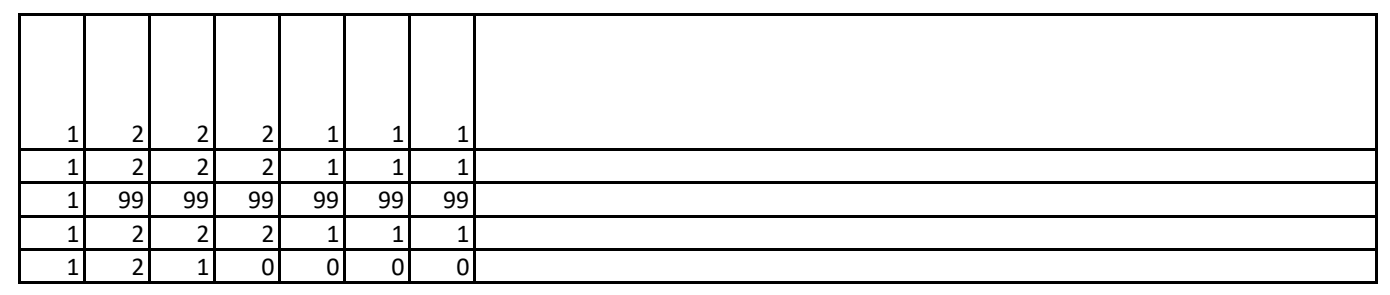


Anexo 2 - Chave de análise 
Dados Gerais

\section{Roteiro para ficha de análise iconográfica}

Campo que compreende dados de identificação da peça e de suas condições físicas de um modo geral.

Número da Peça

Proveniência

Integridade da Peça

1. Inteira ( $91 \%$ a $100 \%$ de integridade)

2. Pouco fragmentada (61\% a $90 \%$ de integridade)

3. Muito fragmentada (50\% a $60 \%$ de interidade)

Estado de Preservação dos Motivos

1. Bom (fundo e motivos nítidos e bem preservados)

2. Regular (fundo e motivos nítidos, porém com poucas partes desgastadas)

3. Ruim (fundo e motivos bem desgastados)

99. Sem leitura

\section{Aspectos Produtivos}

Técnica de Manufatura

1. Acordelada

2. Modelada

3. Acordelada/ Modelada

99. Sem leitura

Tipo de antiplástico

1. Mineral

2. Caco Moído
3. Carvão

4. Cariapé

5. Mineral+caco moído

6. Mineral+caco moído+carvão

99. Sem leitura

Composição da pasta

1. Pasta muito Plástica (10\% ou menos de antiplástico)

2. Pasta Plástica (10-30\% de antiplástico)

3. Pasta Seca (mais de $30 \%$ de antiplástico)

Tratamento de superfície interno superior/inferior

1. Alisado

2. Alisado ruim

3. Barbotina ${ }^{1}$

4. Banho $^{2}$

5. Pintura

6. Engobo

99. Sem leitura

Tratamento de superfície externo superior/inferior
1. Alisado
2. Alisado ruim
3. Barbotina
4. Banho
5. Pintura
6. Engobo
7. Pintura + tratamento plástico
99. Sem leitura

denominaram essa camada como barbotina "um revestimento superficial de argila mais refinada, aplicado à cerâmica antes da queima" (1989: 17)

${ }^{2}$ Revestimento com espessura delgada, igual ou menor que $1 \mathrm{~mm}$ (La Salvia \&

Brochado 1989: 18), com coloração diferente ou não daquela observada no plano de fratura da peça. 
Queima

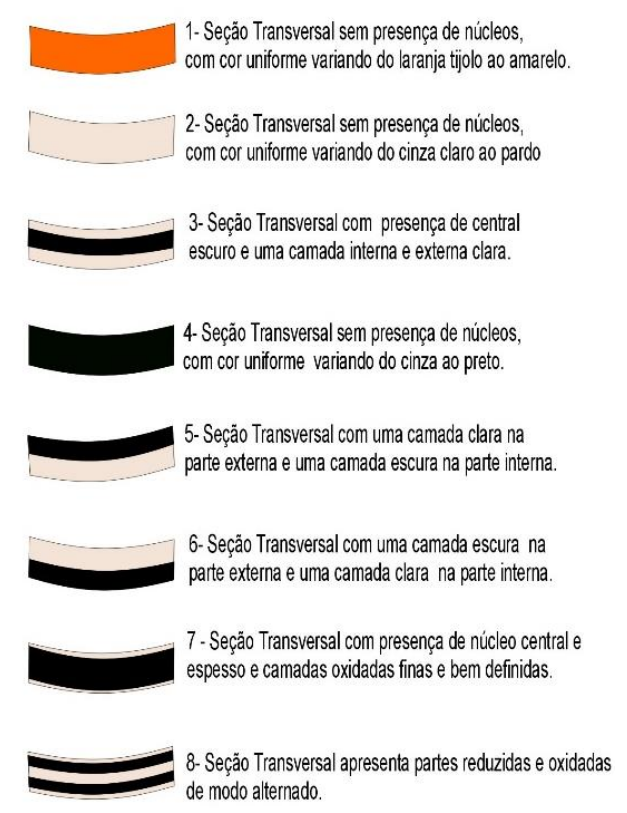

Técnica de produção dos grafismos

1. Dedos

2. Pincel fino

3. Pincel grosso

Forma

Base
1. Convexa
2. Côncava
3. Plana
4. Em pedestal

Borda
1. Direta
2. Extrovertida
3. Introvertida
4. Cambada
5. Contraída
99. Não identificada

Espessura da borda em relação ao corpo

1. Mesma espessura

2. Reforçada externa

3. Reforçada interna

4. Reforçada interna e externa

Lábio

1. Apontado

2. Arredondado

3. Plano

4. Biselado

99. Sem leitura

Diâmetro da borda

Contorno da boca
1. Circular
2. Elíptica
3. Quadrangular
4. Retangular

Contorno (Chmiz, 1976)
1. Simples
2. Composta
3. Complexa 


\section{Estrutura geral da vasilha}

1. Restrita

2. Levemente restrita

3. Aberta

Maior largura

Altura

Pintura/Decoração

Quantidade de campos gráficos

Localização dos campos gráficos

1. Face interna

2. Face externa

Cor dos Motivos

1. Vermelho

2. Preto

3. Marrom escuro

4. Vermelho+preto

99. Sem leitura

Cor do Engobo

1. Branco

2. Bege Claro

3. Branco levemente rosado

4. Acinzentado

Gênero dos Motivos

1. Simples

2. Composto

3. Composto+simples

Categoria dos motivos

1. Retilíneo

2. Curvilíneo
3. Retilíneo e curvilíneo

4. Pontilhado 